GABRIEL SAAD KIK BUSCHINELLI

\title{
ABUSO DO DIREITO DE VOTO NA ASSEMBLEIA GERAL DE CREDORES
}

DISSERTAÇÃO DE MESTRADO EM DIREITO COMERCIAL

\author{
ORIENTADOR
}

Prof. AsSOCIADO DR. EdUARdo SECCHI MUNHOZ

FACULDADE DE DIREITO DA UNIVERSIDADE DE SÃO PAULO

SÃO PAULO

2013 


\title{
GABRIEL SAAD KIK BUSCHINELLI
}

\section{ABUSO DO DIREITO DE VOTO NA ASSEMBLEIA GERAL DE CREDORES}

\author{
Dissertação apresentada à Comissão \\ de Pós-Graduação em Direito da \\ Universidade de São Paulo, como \\ exigência parcial para a obtenção do \\ título de Mestre em Direito Comercial, \\ sob orientação do Professor Associado \\ Doutor Eduardo Secchi Munhoz.
}

DISSERTAÇÃO DE MESTRADO EM DIREITO COMERCIAL

ORIENTADOR

Prof. AsSOCIADO DR. EdUARdo SECCHI MUNHOZ

FACULDADE DE DIREITO DA UNIVERSIDADE DE SÃO PAULO

SÃo Paulo 


\section{SUMÁRIO}

AGRADECIMENTOS ............................................................................................................ IV

ABREVIATURAS .................................................................................................................. VI

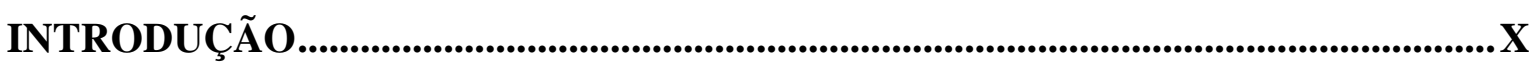

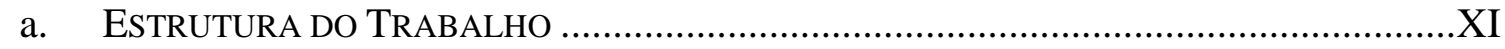

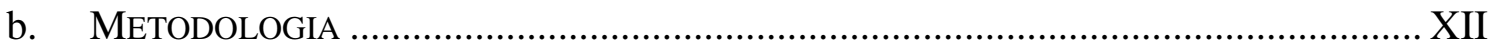

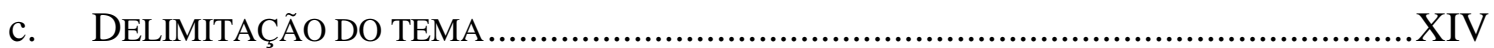

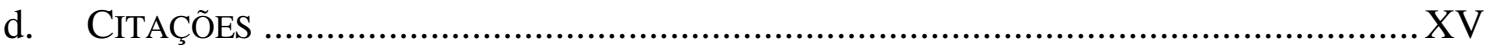

1. COLETIVIDADE DE CREDORES: NATUREZA JURÍDICA, PRINCÍPIO MAJORITÁRIO E DEVER DE LEALDADE......................................................................1

1.1. NATUREZA JURÍDICA DA COLETIVIDADE DE CREDORES ..........................................2

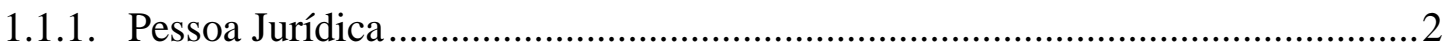

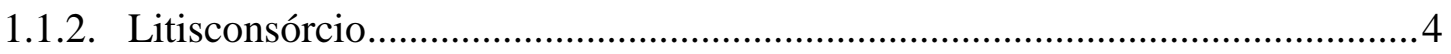

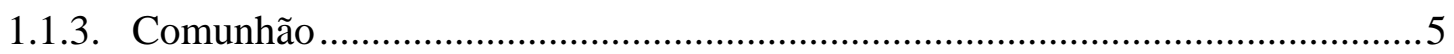

1.1.3.1. Comunhão de tipo germânico e condomínio de tipo romano ......................5

1.1.3.2. A concepção de Rocco: credores como titulares em mão comum ............6 6

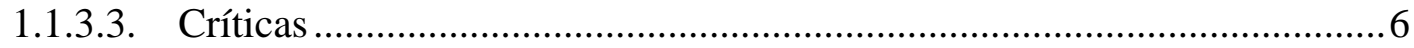

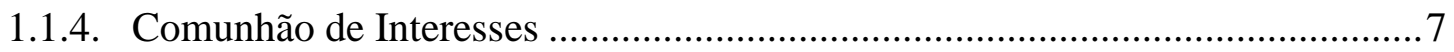

1.1.4.1. A “descoberta” jurídica de Jhering ........................................................

1.1.4.2. A sistematização proposta por Phillip Heck .......................................... 8

1.1.4.3. Recepção jurisprudencial e doutrinária..................................................... 11

1.1.4.4. Reconhecimento da coletividade de credores como comunhão de

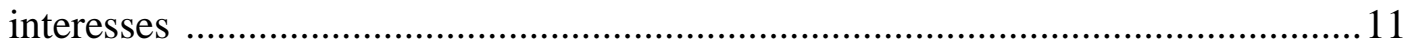

1.1.4.5. A comunhão de interesses no direito brasileiro e a natureza jurídica da

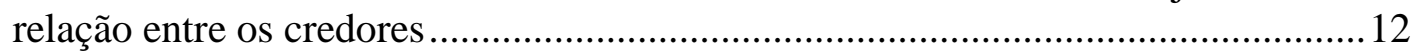

1.2. DEVER DE LEALDADE ENTRE OS CREDORES …..................................................... 13

1.2.1. Desenvolvimento histórico do dever de lealdade societário............................. 13

1.2.1.1. Primeiro período: a jurisprudência a serviço do poder majoritário ..........13

1.2.1.2. Segundo período: o progressivo alargamento do dever de lealdade......... 14

1.2.2. Fundamento dogmático do dever de lealdade societário ................................. 18

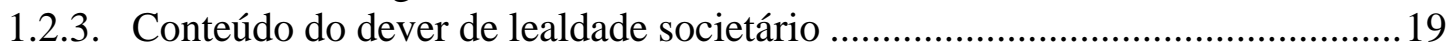

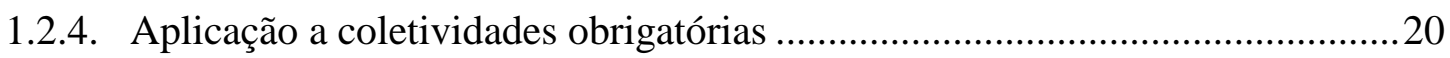

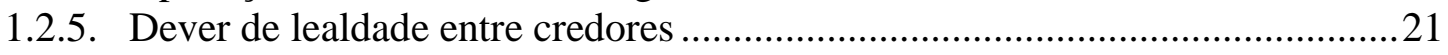

1.2.6. Conteúdo do dever de lealdade entre os credores ..........................................23

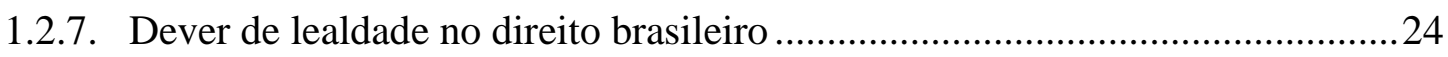

\section{ABUSO DO DIREITO DE VOTO PELO CREDOR: FUNDAMENTOS}

DOGMÁTICOS .................................................................................................................25

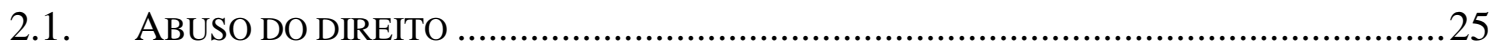

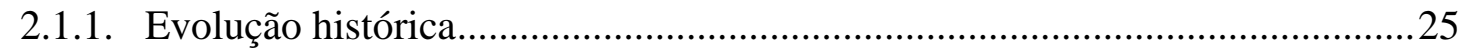

2.1.2. O abuso do direito no Brasil: um instituto entre duas tradições .......................31

2.1.3. Contornos dogmáticos e aplicação ao exercício do direito de voto...................33

2.1.3.1. Abuso no exercício do direito de voto ....................................................... 34

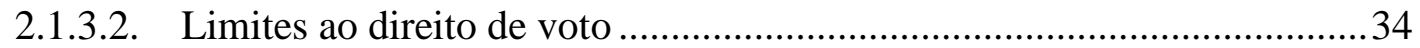

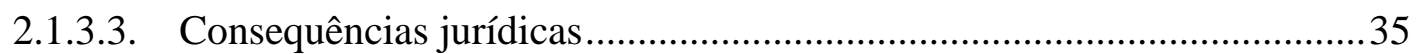

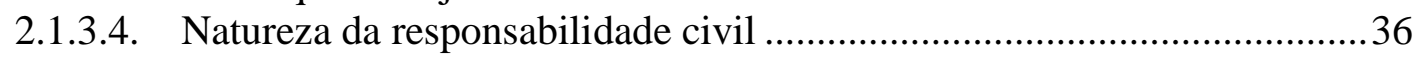




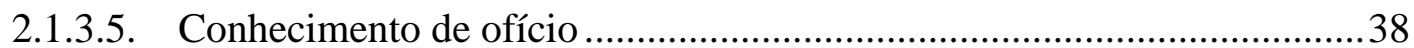

2.1.3.6. Necessidade de que limites sejam excedidos "manifestamente"..............38

2.2. LIMITES AO EXERCÍCIO DO DIREITO DE VOTO PELO CREDOR...................................39

2.2.1. Direito de voto como poder funcional norteado pela preservação da empresa

em crise e promoção de sua função social ..................................................................40

2.2.1.1. Abuso do direito de voto por desrespeito à função social .......................42

2.2.1.2. Promoção procedimental da função social ..............................................4 44

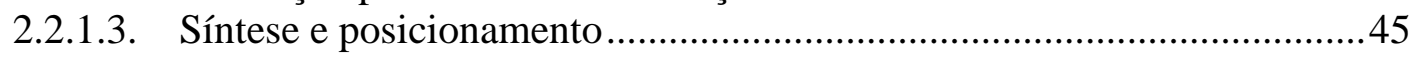

2.2.2. Direito de voto limitado por boa-fé em relação ao devedor .............................46

2.2.3. Direito de voto limitado pelo dever de lealdade entre os credores ...................49

2.3. EXCURSO: NECESSÁRIA ANÁLISE PRÉVIA DA LEGALIDADE DO PLANO PARA A

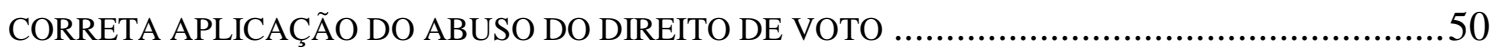

2.3.1. Principais ilegalidades no plano de recuperação judicial ...............................51

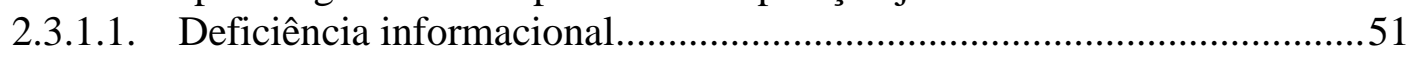

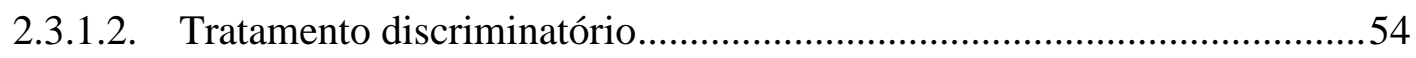

2.3.1.2.1. Classes de credores com interesses heterogêneos...............................54

2.3.1.2.2. Desigualdade de tratamento entre integrantes de uma classe ..............57

2.3.2. Consequências para a análise do abuso do direito de voto ................................60

3. IMPEDIMENTO DE VOTO ...........................................................................662

3.1. HIPÓTESES PREVISTAS NA LEI DE RECUPERAÇÃO E FALÊNCIA ….............................62

3.2. ADEQUAÇÃO DE REGRA DE IMPEDIMENTO DE VOTO NA RECUPERAÇÃO JUDICIAL .63

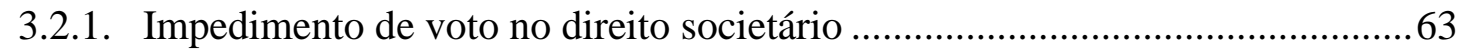

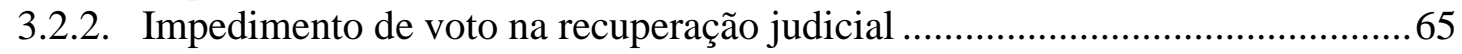

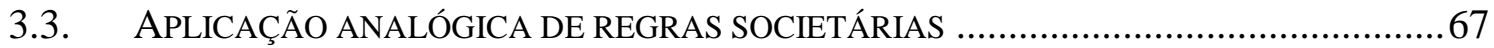

3.4. SITUAÇÕES NÃO CONTEMPLADAS EXPRESSAMENTE PELA LEI ............................... 71

3.4.1. Impedimento de voto imposto a todos os credores integrantes de uma classe 72

3.4.2. Alienação fiduciária em garantia de participações societárias da sociedade

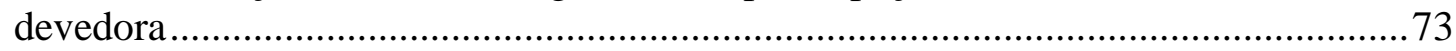

3.4.3. Cessão de crédito por credor impedido de votar.......................................... 75

4. ABUSO DO DIREITO DE VOTO PELO CREDOR: AFERIÇÃO E

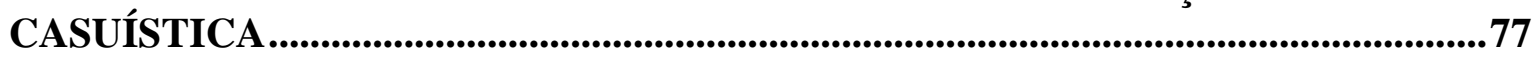

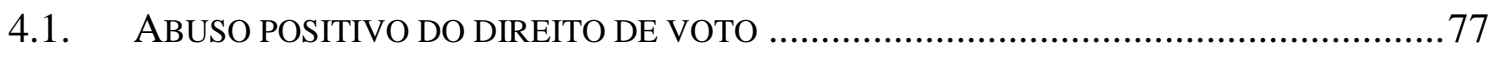

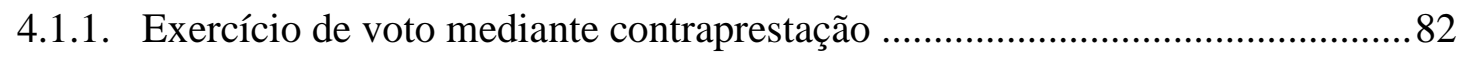

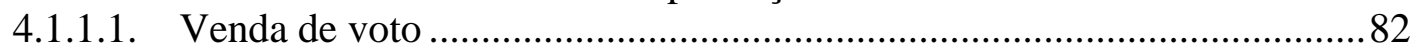

4.1.1.2. Celebração de contrato preliminar entre devedor e credor ....................... 85

4.1.1.3. Plano que prevê celebração de negócio jurídico com credor....................86

4.1.1.4. Perspectiva de celebração de novos contratos com o devedor .................87

4.1.2. Abuso do direito de voto por tratativas com devedor ..................................... 88

4.1.2.1. Licitude de tratativas bilaterais entre credor e devedor ...........................89

4.1.2.2. Licitude de acordo para exercício do direito de voto............................... 90

4.1.3. Cessão de crédito .......................................................................................90

4.1.3.1. Problemas relacionados à cessão de créditos concursais e tratamento no direito estrangeiro ..................................................................................... 91

4.1.3.2. Exercício do direito de voto em caso de cessão de crédito durante o

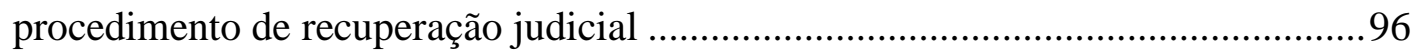

4.1.3.3. Abuso do direito de voto por credor cessionário .................................. 100

4.1.4. Credor com garantias prestadas por terceiros ............................................... 101

4.1.4.1. Efeitos da novação recuperacional sobre garantias prestadas por terceiros 
4.1.4.2. Voto exercido pelo credor garantido por terceiro em detrimento dos demais credores.

4.1.4.3. Credor garantido por alienação fiduciária ou penhor de participações

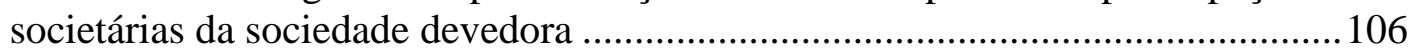

4.1.5. Credor com créditos em mais de uma classe ................................................106

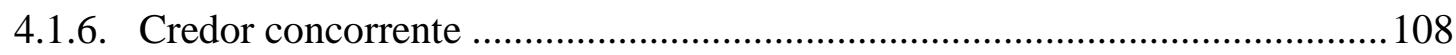

4.1.7. Risco de sujeição à ineficácia ou à revogação em caso de falência ...............110

4.2. ABUSO NEGATIVO DO DIREITO DE VOTO: VETO OBSTRUTIVO ............................112

4.2.1. Instrumentos para a superação do veto abusivo.........................................113

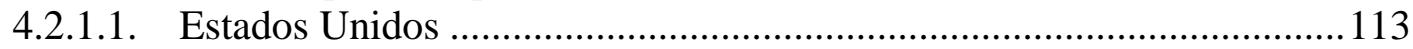

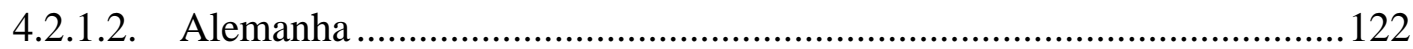

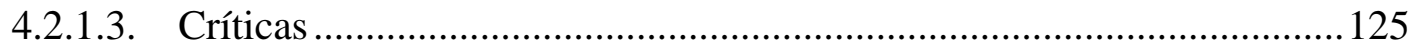

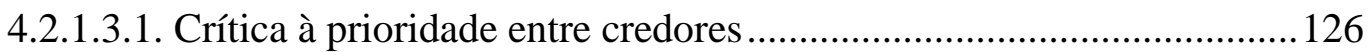

4.2.1.3.2. Crítica à prioridade entre credores e devedor .....................................128

4.2.1.3.3. Crítica à necessidade de avaliação judicial........................................130

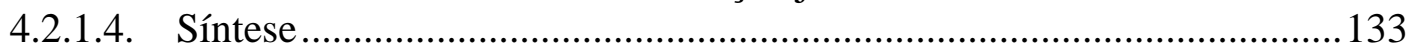

4.2.2. Abuso do direito de voto como forma de controle do comportamento

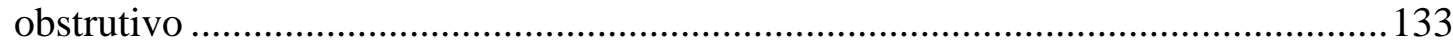

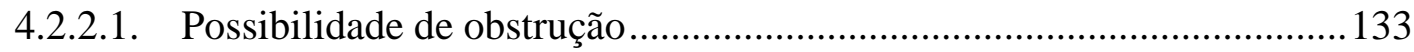

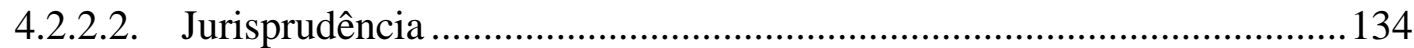

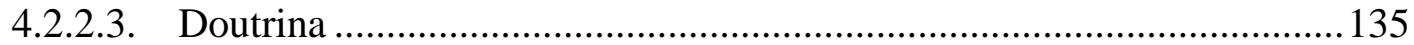

4.2.2.4. Posicionamento: possibilidade de abuso do direito de voto por

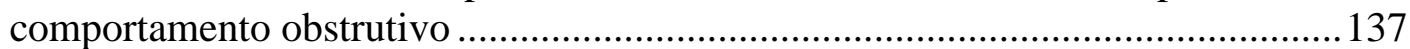

4.2.2.4.1. Possibilidade de que falência seja prejudicial aos credores................137

4.2.2.4.2. Critérios para verificação do voto abusivo .......................................... 138

4.2.2.4.3. Comparação de posicionamento com solução norte-americana .........140

4.2.2.4.4. Casuística ...................................................................................... 142

5. SANÇÕES AO ABUSO DO DIREITO DE VOTO .........................................144

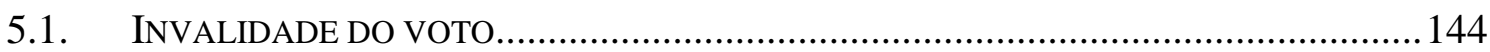

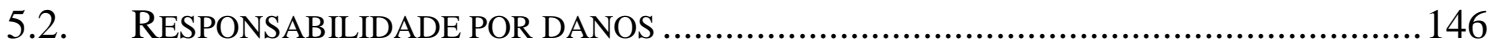

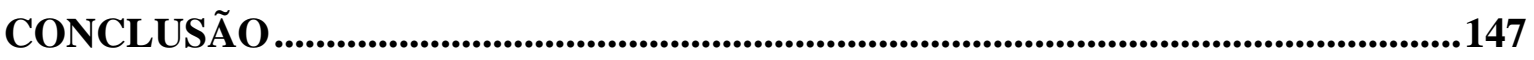

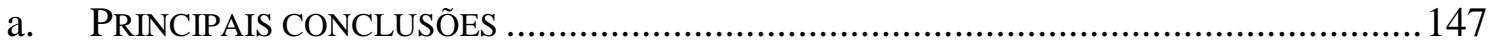

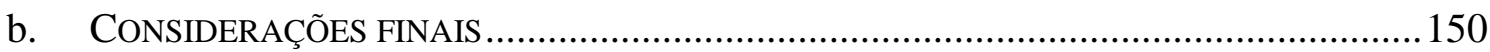

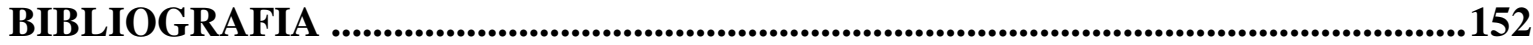

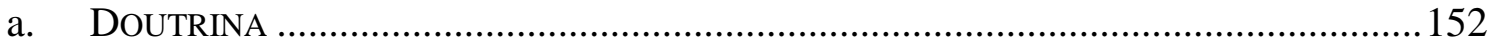

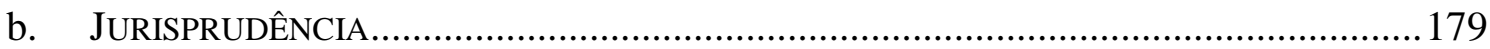

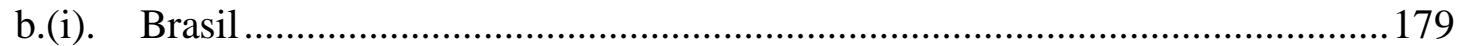

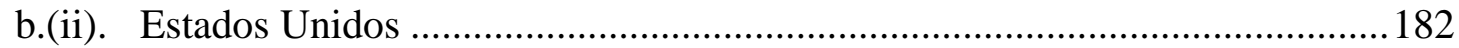

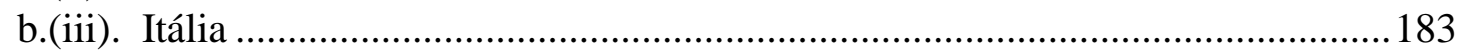

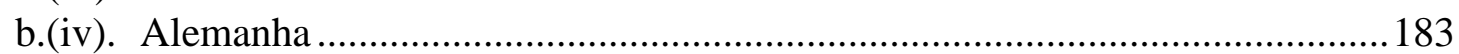

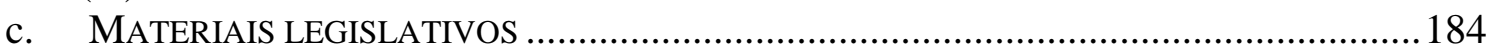

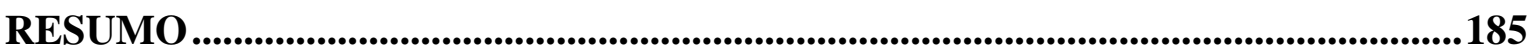

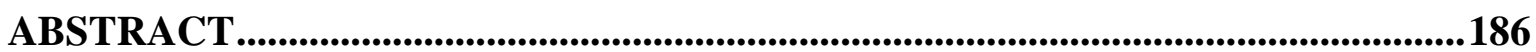




\section{AGRADECIMENTOS}

O presente trabalho resulta de uma longa jornada. Sua conclusão somente foi possível graças à confluência de diversas contribuições.

Meu orientador, Professor Eduardo Secchi Munhoz, profundo conhecedor da teoria e da prática da recuperação judicial, esteve sempre disponível para discutir as dúvidas que se acumulavam durante o período de pesquisa e, com segurança, guiou-me ao longo do caminho. Tive, além disso, o privilégio de com ele conviver profissionalmente; advogado brilhante, ensinou-me que a advocacia é, e sempre será, uma arte.

Os Professores Erasmo Valladão Azevedo e Novaes França e José Alexandre Tavares Guerreiro compuseram a banca que argüiu meu projeto de qualificação para o mestrado e fizeram, naquela ocasião, valorosas observações que muito contribuiram para o aperfeiçoamento deste estudo. Com o Professor Erasmo aprendi muito no curso de pósgradução, mas, principalmente, nas longas conversas, que iam muito além do Direito. Com o Professor Guerreiro tive a honra de conviver; é um enorme prazer poder desfrutar de seu brilhantismo e surpreender-me, todos os dias, com sua inteligência e com sua sabedoria.

Durante o mês de julho de 2010, fui recebido como pesquisador visitante no Max-PlanckInstitut für ausländisches und internationales Privatrecht, na cidade de Hamburgo, na Alemanha. O agradável verão na Pérola do Norte tornou-se possível graças ao incentivo do Dr. Jan Peter Schmidt. Com o Dr. Felix Steffek, muito gentil e solícito, pude discutir meu tema largamente. A estada não seria a mesma sem minhas colegas lusófonas, Mariana Craveiro, Elena Gomes e Catarina Pires. Embora a biblioteca do Instituto seja mundialmente conhecida, curiosamente, é no café que mais se aprende.

Em dezembro de 2011, regressei à Alemanha, dessa vez à cidade de Munique, onde permaneci por três meses como pesquisador visitante junto à Ludwig-MaximiliansUniversität. Lá, tive o privilégio de ser orientado pelo Prof. Dr. Horst Eidenmüller, autoridade no assunto objeto desta dissertação. Ele me acolheu generosamente em seu instituto e me auxiliou a conceber este trabalho. O retorno à querida capital bávara, onde antes já residira, somente foi possível graças ao subsídio do Bayerisches Hochschulzentrum für Lateinamerika, que me agraciou com bolsa de estudos durante o período. 
No curso da pesquisa, deparei-me, por vezes, com a impossibilidade de obter certas obras indisponíveis no Brasil ou em livrarias internacionais. Como última esperança, escrevi aos respectivos autores e fui brindado com demonstrações de puro espírito acadêmico. É o caso do Prof. Dr. Roberto Sacchi, da Universidade de Turim, que me enviou versão digitalizada de seu precioso livro sobre o princípio da maioria em procedimentos concursais; e do Dr. Peter Stelzig, que me presenteou com sua rica tese sobre a história do dever de lealdade dos acionistas.

Entre as diversas pessoas com quem pude discutir o presente trabalho, menciono especialmente a Dra. Sheila Christina Neder Cerezetti, a Dra. Flavia Foz Mange,a Dra. Laura Patella, o Dr. Luis Felipe Spinelli e o Dr. Paulo Fernando Campana Filho. Tive também a oportunidade de conversar sobre meu tema com colegas e amigos de escritório. Sabendo que, injustamente, deixo de nomear diversos deles, relembro aqui o quanto pude aprender com a experiência do Dr. Alexei Bonamin, do Dr. Marcelo Pádua, do Dr. Raphael Correa, da Dra. Mariana Calejon e da Dra. Esther Slud.

Os amigos Flávio Beicker e Patrick Luna estiveram sempre presentes, e Sérgio Mendes Filho fez leitura atenta de versão preliminar deste estudo e ofereceu conselhos para seu aprimoramento. Thiago Tannous, fraterno amigo, esteve comigo desde a matrícula no curso de pós-graduação até o depósito desta dissertação, leu-na ainda in fieri e, como sempre, foi ao âmago do trabalho para tecer considerações muito relevantes.

A pesquisa ora apresentada somente foi possível graças ao constante apoio de meus familiares. De meus pais, Paulo e Valéria, que dedicaram tantos anos à minha formação. De minhas irmãs, Juliana e Giovanna, que me ofereceram seu carinho e sua amizade. E de meus queridos avós, José e Sônia, mencionados em nome dos demais membros de minha família, que sempre estimularam minha dedicação aos estudos - desde o primeiro gibi que me deram na praia.

Por fim, Belisa, minha amada companheira, esteve ao meu lado nesse percurso, sofreu quando a distância de um oceano nos separou por três longos meses e vibrou junto comigo a cada passo.

A todos vocês, meus mais sinceros agradecimentos! 


\section{ABREVIATURAS}

ABI L. Rev.

$\operatorname{AgRg}$

Am. Bankr. L. J.

Am. J. Comp. L.

Ann. Surv. Am. L.

art.

B. C. Int'l \& Comp. L. Boston College International \& Comparative Law Review Rev.

Bankr. Dev. J.

BC

Bell J. Econ.

BGH

Brook. J. Corp. Fin. \& Com. L.

BT/Drucksache

Bus. Law.

c/c

Cardozo L. Rev

CC

CCom

CF

cit.

Colum. Bus. L. Rev.

Colum. L. Rev.

Cornell L. Rev.

CP

CPC

American Bankruptcy Institute Law Review (periódico estadunidense)

Agravo Regimental

American Bankruptcy Law Journal (periódico estadunidense)

American Journal of Comparative Law (periódico estadunidense)

Annual Survey of American Law (periódico estadunidense)

Artigo

(periódico estadunidense)

Bankruptcy Developments Journal (periódico estadunidense)

Bankruptcy Code (legislação concursal estadunidense)

Bell Journal of Economics (periódico estadunidense)

Bundesgerichtshof (Tribunal Federal Alemão)

The Brooklyn Journal of Corporate, Financial \& Commercial Law (periódico estadunidense)

Drucksachen des Deutschen Bundestages (periódico oficial de documentação legislativa do parlamento alemão)

The Business Lawyer (periódico estadunidense)

Cumulado com

Cardozo Law Review (periódico estadunidense)

Código Civil (Lei n. 10.406, de 10.01.2002)

Código Comercial Brasileiro (Lei n. 556, de 25.06.1850)

Constituição Federal

Obra citada

Columbia Business Law Review (periódico estadunidense)

Columbia Law Review (periódico estadunidense)

Cornell Law Review (periódico estadunidense)

Código Penal (Decreto-Lei n. 2.848, de 07.12.1940)

Código de Processo Civil (Lei n. 5.869, de 11.01.1973) 

Des. Desembargador
Dir. e Proc. $\quad$ Diritto e processo (periódico italiano)
Dir. Fall. Il diritto fallimentare e delle società commerciali (periódico
DZWIR Deutsche Zeitschrift für Wirtschafts- und Insolvenzrecht (periódico alemão)

ECFR European Company and Financial Law Review (periódico alemão)

EDiv em AG Embargos de divergência em agravo de instrumento

Emory Bankr. Dev. J. Emory Bakruptcy Development Journal (periódico estadunidense)

Harv. L. Rev. Harvard Law Review (periódico estadunidense)

Il Fallimento Il fallimento e le altre procedure concorsuali (periódico italiano)

Ind. L. Rev. $\quad$ Indiana Law Review (periódico estadunidense)

InsO Insolvenzordnung (legislação concursal alemã)

InVo Insolvenz \& Vollstreckung (periódico alemão)

Iowa L. Rev Iowa Law Review (periódico estadunidense)

J. Fin. The Journal of Finance (periódico estadunidense)

JZ Juristenzeitung (periódico alemão)

KTS Zeitschrift für Insolvenzrecht, Konkurs, Treuhand, Sanierung (periódico alemão)

Leg. Fall. $\quad$ Legge fallimentare (legislação concursal italiana)

LRF / Lei de Lei de Recuperação de Empresas e Falência (Lei n. 11.101, de Recuperação e Falência 09.02.2005)

LSA Lei das Sociedades por Ações (Lei n. 6.404, de 15.12.1976)

Mich. L. Rev. Michigan Law Review (periódico estadunidense)

Min. Ministro

n. Número

N. C. L. Rev. North Carolina Law Review (periódico estadunidense)

NJW Neue Juristische Wochenzeitschrift (periódico alemão)

Nw. U. L. Rev. Northwestern University Law Review (periódico estadunidense)

NZI Neue Zeitschrift für das Recht der Insolvenz und Sanierung 
(periódico alemão)

p. / pp.

par. ún.

PL

RDB

RDCLBr

RDM

Rel.

RGZ

RIDC

Riv. Civ.

Riv. Dir. Comm.

Rn.

ROA

RTDC

RTDPC

St. Thomas L. Rev.

T.

Tex. L. Rev.

TJRJ

TJRO

TJRS

TJSP

U. Chi. L. Rev.

U. Pa. L. Rev.
Página / Páginas

Parágrafo único

Projeto de lei

Revista de Direito Bancário e do Mercado de Capitais (periódico brasileiro)

Revista de Direito Comparado Luso-Brasileiro (periódico brasileiro)

Revista de Direito Mercantil, Industrial, Econômico e Financeiro (periódico brasileiro)

Relator

Entscheidungssammlungen der Entscheidungen des Reichsgerichts in Zivilsachen (coletânea de decisões do Tribunal do Império Alemão em matéria civil)

Revue Internationale de Droit Comparé (periódico francês)

Rivista di diritto civile (periódico italiano)

Rivista del diritto commerciale e del diritto generale delle obbligazzioni (periódico italiano)

Randnummer (número de margem de página)

Revista da Ordem dos Advogados (periódico português)

Revista Trimestral de Direito Civil (periódico brasileiro)

Rivista trimestrale di diritto e procedura civile (periódico italiano)

St. Thomas Law Review (periódico estadunidense)

Turma

Texas Law Review

Tribunal de Justiça do Estado do Rio de Janeiro

Tribunal de Justiça do Estado de Roraima

Tribunal de Justiça do Estado do Rio Grande do Sul

Tribunal de Justiça do Estado de São Paulo

The University of Chicago Law Review (periódico estadunidense)

The University of Pennsylvania Law Review (periódico 
estadunidense)

U.Cin. L. Rev.

The University of Cincinnati Law Review (periódico estadunidense)

UCLA L. Rev.

v.m.

v.u.

Va. L. Rev.

vol.

Wash. U. L. Q.

Wash. U. L. Rev.

Yale L. J.

ZGR

ZHR

ZInsO

ZIP

ZZP
UCLA Law Review (periódico estadunidense)

Votação por maioria

Votação unânime

Virginia Law Review (periódico estadunidense)

Volume

Washington University Law Quarterly (periódico estadunidense)

Washington University Law Review (periódico estadunidense)

Yale Law Journal (periódico estadunidense)

Zeitschrift für das gesamte Unternehmens- und Gesellschaftsrecht (periódico alemão)

Zeitschrift für das gesamte Handelsrecht und Wirtschaftsrecht (periódigo alemão)

Zeitschrift für das gesamte Insolvenzrecht (periódico alemão)

Zeitschrift für Wirtschaftsrecht (periódico alemão)

Zeitschrift für Zivilprozeß (periódico alemão) 


\section{INTRODUÇÃO}

O antigo sistema falimentar, estruturado sob o Decreto-lei n. 7.661/45, não mais atendia aos anseios da realidade empresarial. A falência não se mostrava como instrumento apto à preservação da empresa; a concordata era concedida pelo juiz contra o interesse dos credores. A destruição de riquezas e de vidas era a regra. Uma alteração era reclamada há tempos. ${ }^{1}$

A Lei n. 11.101, de 09.02.2005, buscou alterar esse cenário. A preservação da empresa tornou-se objetivo central do processo falimentar (LRF, art. 75). Como inovação, introduziu-se o instituto da recuperação judicial. Motivada pela crença de que os credores economicamente interessados são os mais aptos a decidir acerca do futuro da empresa em crise, a lei confiou que devedor e credores poderiam encontrar soluções consensuais para a manutenção da empresa.

Definido o objetivo, faltou ao legislador cuidado para refletir acerca da melhor forma de alcançá-lo. A lei é pródiga na concessão de direitos e na proclamação de princípios. Pouco se preocupa, contudo, com o aspecto principal de qualquer sistema de soluções consensuais: estruturar a negociação entre devedor e credores.

O legislador foi sucinto. Não há regras de controle ao comportamento abusivo. A despeito da considerável divergência de interesses entre os credores, estes são situados em apenas três classes obrigatórias.

Não é preciso ir longe para perceber que a regra majoritária nem sempre proporciona resultados equânimes. O direito societário acumula experiência na percepção de que a regra majoritária pode levar a graves iniquidades, se não for conjugada com regras estruturais de garantia da integridade do procedimento deliberativo.

O abuso do direito de voto pode ocorrer em todas as coletividades. Entre essas, a coletividade de credores é talvez uma das mais propícias à ocorrência de desvios. Todos os

1 Por todos, cf. RUBENS REQUiÃo, "A Crise do direito Falimentar Brasileiro - Reforma da Lei de Falências", in $R D B$, vol. 20, 2003, pp. 199-207 (=RDM, vol. 14, 1974, pp. 23-33). 
credores integram-na exclusivamente para obter a satisfação de seus créditos, e a solidariedade espontânea é o que menos frequentemente motivará suas atitudes.

Ainda assim, não pode o direito assistir impassivo a situações de abuso. A regularidade de um processo deliberativo depende da correta compreensão dos limites impostos ao exercício do direito de voto. Este trabalho busca contribuir para o desiderato de melhor esclarecê-los.

\section{a. Estrutura do Trabalho}

O trabalho está estruturado em cinco capítulos.

O Capítulo 1 analisa a natureza da coletividade de credores. Busca, desse modo, saber se há, entre os credores, uma relação jurídica que os una. Passo subsequente, indaga a legitimidade de decisões majoritárias entre credores, bem como a possível existência de deveres deveres de lealdade recíprocos.

O Capítulo 2 analisa o instituto do abuso do direito e questiona a possibilidade de abuso do direito de voto pelo credor. Para diferenciar abuso do direito de uso regular do direito, busca-se definir um parâmetro adequado para a avaliação da conduta dos credores. Indagase a possibilidade de considerar a função social da empresa, a boa-fé ante o devedor, ou o dever de lealdade entre os credores como limite à sua atuação. $\mathrm{O}$ capítulo encerra com um excurso necessário e relevante para o controle do abuso do direito de voto pelo credor: não é possível sancionar o comportamento do credor sem antes garantir que o plano de recuperação judicial proposto para sua deliberação cumpra a lei.

O Capítulo 3 enfrenta um problema anterior ao estudo do abuso do direito, que é o de determinar quais credores podem votar na assembleia geral de credores. Trata-se de questão diretamente relacionada ao abuso do direito de voto, seja porque o direito de voto é pressuposto necessário para a possibilidade de abuso, seja porque hipóteses de impedimento de voto podem, em tese, afastar previamente do conclave credores que provavelmente irão atuar de forma abusiva. São analisadas, portanto, as hipóteses de impedimento de voto previstas na lei. O estudo questiona a sua conveniência, bem como a 
possibilidade de aplicação analógica de regras societárias de impedimento de voto e finaliza com a análise de situações polêmicas e pouco analisadas na doutrina.

O Capítulo 4 constitui o cerne do trabalho. Tem por meta responder à indagação central que motivou a investigação, que é a de saber quando há abuso do direito de voto pelo credor em deliberação acerca do plano de recuperação judicial. Analisam-se as possíveis formas de abuso do direito de voto, de sua aferição e busca-se, de forma não exaustiva, apresentar casuística de situações que caracterizem, ou possam caracterizar, abuso do direito de voto.

O Capítulo 5 delimita, por fim, as sanções que podem ser impostas em decorrência do abuso do direito de voto.

Ao final dos cinco capítulos, a Conclusão sintetiza os principais resultados alcançados e oferece considerações finais.

\section{b. METODOLOGIA}

Nos dois primeiros capítulos, analisam-se a natureza da coletividade de credores, o princípio majoritário, o dever de lealdade entre os credores, o abuso do direito e os limites ao direito de voto. Para isso, são estudados os diversos institutos jurídicos em persectiva histórica, por vezes em mais de um ordenamento jurídico. Com esse método, é possível visualizar o que os institutos têm de comum e característico, com a devida análise de diferenças específicas no curso de seu desenvolvimento. ${ }^{2}$

Nos dois capítulos subsequentes, a investigação das hipóteses de impedimento de voto e de abuso do direito de voto parte da legislação em vigor e da jurisprudência, mas emprega análises de direito comparado com outros países que adotam soluções negociadas entre devedor e credores. O valor do direito comparado para o estudo jurídico é amplamente reconhecido, ${ }^{3}$ mas é preciso esclarecer a forma como se procedeu à comparação jurídica no presente trabalho.

2 Tullio Ascarelli, "Premissas ao Estudo do Direito Comparado", in Problemas das Sociedades Anônimas e Direito Comparado, $2^{a}$ ed., São Paulo, Saraiva, 1969, pp. 1-44, p. 11

3 Id., p. 4. 
Embora a prática de direito comparado seja antiga, associa-se o surgimento do direito comparado entendido como ramo autônomo da ciência jurídica à Exposição Universal de Paris, em 1900. ${ }^{4}$ É reconhecido que o direito comparado ainda não dispõe de um fundamento teórico sólido. ${ }^{5}$ Não há consenso quanto às condições para que o direito de dois países possa ser comparado, nem quanto à melhor forma de fazê-lo. ${ }^{6}$ Por conta disso, afirmam Konrad Zweigert e Hein Kötz que, ainda hoje, não se conseguiu - e, talvez, nunca se conseguirá - desenvolver uma metodologia própria do direito comparado. Acreditam os autores que, ao final, sempre restará uma área em que somente o “juízo, o senso comum ou mesmo a inspiração podem ajudar". ${ }^{7}$ Isso não quer dizer que não existam técnicas ou princípios metodológicos que devam ser considerados. O método da comparação funcional, nesse sentido, é o mais comumente adotado. Ele se pauta pela análise da função concretamente exercida pelos institutos jurídicos análogos em ordenamentos diversos ${ }^{8}$ e é o método empregado no presente trabalho.

Para selecionar o material de comparação, buscou-se, primeiramente, delimitar o campo de pesquisa. Foram abordados apenas os sistemas concursais que permitissem alguma forma de solução consensual entre devedor e credores - ou seja, sistemas nos quais seria mais provável o surgimento de questões atinentes ao abuso do direito de voto por credores. Entre os países que correspondiam aos critérios, restringiu-se a pesquisa àqueles com produção jurídica mais representativa e acessível, com limitação da análise aos seguintes países: Alemanha, Espanha, Estados Unidos, França, Inglaterra, Itália e Portugal. Realizado levantamento preliminar, constatou-se que discussões pertinentes ao objeto da presente investigação eram mais frequentes na Alemanha, nos Estados Unidos e na Itália. Legislação, doutrina e jurisprudência desses países foram, em seguida, analisadas mais detidamente.

No curso da exposição - em linha com a recomendação de Zweigert e de Kötz -, optou-se por proceder à análise das soluções encontradas nos países estrangeiros no âmbito de cada

$4 \quad$ KONRAD ZWEIGERT e HEIN KÖTZ, Einführung in die Rechtsvergleichung, $3^{\mathrm{a}}$ ed., Tübingen, Mohr Siebeck, 1996, §1 I, pp. 1-4.

5 MAThias Reinmann, "The Progress and Failure of Comparative Law in the Second Half of the Twentieth Century”, in Am. J. Comp. L., vol. 50, 2002, pp. 671-700, pp. 687-689.

$6 \quad$ Id., pp. 689-690

7 KONRAD ZWEIGERT, HEIN KÖTZ, Einführung in die Rechtsvergleichung, cit., §3 I, p. 32.

$8 \quad$ Id., $\$ 3$ II, p. 33. 
item tematicamente pertinente, e não em capítulo introdutório. ${ }^{9}$ Cumpre ressaltar, ademais, que problemas análogos aos brasileiros nem sempre são encontrados em todos os países simultaneamente. Assim, por exemplo, o problema da aplicação analógica de regras societárias de impedimento de voto foi discutido na Alemanha e na Itália, mas não nos Estados Unidos (cf. item 3.3, infra); de modo diverso, questões referentes à legalidade de cessão de créditos concursais têm relevo maior na doutrina norte-americana, mas menor em outros países (cf. item 4.1.3.1, infra). A exposição, em vista disso, aborda em cada item apenas as soluções de direito comparado que, julgou-se, contribuiriam para a melhor compreensão do objeto de estudo.

\section{c. DELIMITAÇÃO DO TEMA}

O abuso do direito de voto na assembleia geral de credores pode ocorrer em qualquer deliberação, seja na recuperação ou na falência. Não se nega o interesse que o abuso do direito de voto em outras deliberações também desperta, mas, caso fossem analisadas todas as hipóteses possíveis, o trabalho teria objeto demasiadamente amplo. A principal deliberação confiada aos credores é, sem dúvida, a deliberação acerca do plano de recuperação judicial. É sobre isso que se debruçam os tribunais e a prática e, portanto, também o presente estudo.

O trabalho busca se ater do modo mais estrito ao objeto da investigação. Por conta disso, não é precedido por uma exposição das alterações promovidas pela Lei de Recuperação e Falência, nem por sua comparação com o regime precedente. Tampouco há uma apresentação de formas consensuais de recuperação judicial encontradas no direito estrangeiro. Remete-se, em vista disso, para obras que expõem essas questões de forma competente $^{10}$ - e superior à que o autor poderia oferecer.

\footnotetext{
9 KONRAD ZWEIGERT, HEIN KÖTZ, Einführung in die Rechtsvergleichung, cit., §3 V, p. 42.

10 Sobre a inovação promovida pela Lei de Recuperação e Falência, cf., por todos,. MAURO Rodrigues Penteado, in Francisco S. DE Souza Junior, AnTÔNio SÉrgio A. DE M. Pitombo (coord.), Comentários à Lei de Recuperação de Empresas e Falência, 2a ed. rev., São Paulo, RT, 2007, pp. 57-88. Para exposição do direito estrangeiro, cf. SHEILA C. N. CEREZETTI, A Recuperação Judicial de Sociedade por Ações - O Princípio da Preservação da Empresa na Lei de Recuperação e Falência, São Paulo, Malheiros, 2012, pp. 88-154; ARIEL A. DASSO, Derecho Concursal Comparado, Tomos I e II, Buenos Aires, Legis, 2008.
} 


\section{d. CiTAÇõES}

As citações de dispositivos normativos são feitas no corpo do texto, de forma abreviada, entre parênteses e sem transcrição. No caso de dispositivos estrangeiros, foi transcrito o texto original em nota de rodapé, quando se julgou conveniente para a maior clareza da exposição.

Nas notas de rodapé, as obras são citadas utilizando a lista de abreviaturas apresentada no início deste trabalho. Na bibliografia final, as obras encontram-se indicadas de forma completa.

A citação de jurisprudência estrangeira é referenciada de acordo com a praxe de notação vigente em cada país.

Os textos são transcritos de acordo com a ortografia vigente à época de sua publicação. As traduções são do autor. 

MAJORITÁRIO E DEVER DE LEALDADE

Enquanto um devedor é solvente, na maioria das vezes, seus credores não se conhecem. Sob o ponto de vista jurídico, a relação entre os credores é marcada pela imunidade. ${ }^{11}$ Cada credor pode exercer sua pretensão em face do devedor de forma autônoma, e não será afetado por decisões tomadas pelos demais credores. Não há igualdade. Entre os credores vige a competição (prior in tempore potior iure).

Com o início de um procedimento concursal, a situação se altera. Os credores exercem seus direitos de forma coletiva; decisões majoritárias podem ser impostas a credores dissidentes; como princípio fundamental, vale a igualdade (par conditio creditorum).

Essa alteração não deriva de um ato voluntário de sujeição de cada credor às regras emanadas pela coletividade. ${ }^{12}$ Os efeitos legais são impostos como decorrência da situação de insuficiência patrimonial enfrentada pelo devedor.

Três questões relevantes apresentam-se para a compreensão dos limites impostos ao exercício de direito de voto pelos credores. Em primeiro lugar, saber se a reunião forçada dos credores os vincula juridicamente, ou se permanecem, como antes, independentes entre si. Em segundo lugar, determinar o que legitima a adoção de decisões majoritárias nessa coletividade de pessoas que sequer se conhecem. Em terceiro lugar, é necessário analisar se, ao adotar decisões majoritárias, cada credor pode agir como melhor lhe convier, ou se está sujeito a um dever de lealdade para com os demais.

\footnotetext{
11 Utiliza-se aqui a classificação das posições jurídicas fundamentais proposta por WESLEY NEWCOMB HOHFELD, que define a situação de imunidade como a ausência de sujeição de um sujeito ao exercício de direitos por outro ("Some Fundamental Legal Conceptions as Applied in Judicial Reasoning", in Yale L. J., vol. 23,1913 , pp. $16-59$, p. 55).

12 Utiliza-se aqui o termo "coletividade de credores", não comunhão, porque comunhão designa uma determinada relação jurídica plurissubjetiva. Ao utilizar o termo neste ponto, estar-se-ia implicitamente aceitando que esta relação jurídica exista, quando é justamente a sua existência que será objeto da investigação que segue. Prefere-se, por enquanto, a utilização dos termos "coletividade" e "grupo", empregados por ROBERTO SACCHI (Il principio di maggioranza nel concordato e nell'amministrazione controllata, Milano, Giuffrè, 1984, p. 10)
} 


\subsection{NATUREZA JURÍdICA DA COLETIVIDADE DE CREDORES}

Com a recepção do direito romano, os juristas continentais enfrentaram o desafio de organizar os diversos institutos que encontravam nas fontes sob categorias de direito privado. $\mathrm{O}$ instituto da cessio bonorum representou, nesse contexto, significativo desafio para os glosadores dos séculos XVII e XVIII. ${ }^{13}$ Como justificar que os credores passassem a ser titulares do poder de alienar judicialmente os bens do devedor para satisfazer seus créditos, e de, em certas situações, adotar decisões majoritárias vinculantes para os credores minoritários?

Para tentar definir a natureza jurídica da relação entre os credores, quatro teorias principais despontam na doutrina. ${ }^{14}$ A primeira é a de que, com o início do procedimento concursal, os credores consituiriam uma pessoa jurídica; a segunda, a de que seu relacionamento teria natureza estritamente processual, formando um litisconsórcio ativo; a terceira, de que formariam comunhão de tipo germânico; e a quarta, de que se estabelece entre os credores uma comunhão de interesses.

\subsubsection{PESSOA JURÍDICA}

O Code de Commerce francês mencionava, originalmente, nos artigos 500, 527 e 528, a "masse des créanciers". A masse, subjetivada pelo legislador, era o ente em nome do qual agia o síndico, com capacidade para assumir dívidas próprias, e para ser titular de um direito de hipoteca comum sobre os bens do devedor - hipoteca que, contudo, não poderia ser excutida por nenhum credor agindo individualmente. Diante dessa situação, pareceu à doutrina francesa que fosse "mais simples e mais correto reconhecer simplesmente a existência de uma pessoa jurídica". ${ }^{15}$ Assim, apesar de ter em conta que entre os credores não surgia uma sociedade, pois faltava para tanto a celebração de contrato associativo,

13 LOTHAR SEUfFERT, Zur Geschichte und Dogmatik des Deutschen Konkursrechts, Nördlingen, C. H. Beck, 1888, pp. 2-75.

14 Ressalte-se, contudo, que há muitas outras teorias difundidas na Alemanha. Sobre o assunto, cf. SABINE VORWERK, Von der typenübergreifenden Gemeinschaft der insolvenzbeteiligten Gläubiger, Marburg, Tectum, 2007, pp. 105-157.

15 Charles Lyon-Caen, Louis Renault, Traité de Droit Commercial, Tome 7, $4^{\mathrm{a}}$ ed., Paris, Librairie Nouvelle de Droit et de Jurisprudence, 1914, n. 472, p. 511: "Il est plus simple et plus juste, selon nous, de reconnaitre l'existence d'une personne morale". No mesmo sentido, EDMOND-EUGÈNE THALLER, Traité Elémentaire de Droit Commercial, $3^{\mathrm{a}}$ ed., Paris, Librairie Nouvelle de Droit et de Jurisprudence, 1904, n. 1071, p. 840: "Nous sommes conduits encore à une autre conséquence. C'est que la masse, le noyau des créanciers groupés afin de liquider la gage commun, forme une veritable personne morale [...]". 
constituiriam eles uma espécie de "associação obrigatória, como as associações sindicais". 16

Já na Alemanha, a concepção de que os credores formariam pessoa jurídica não prevaleceu. A exposição de motivos da Konkursordnung, de 1877, já afirmava: “[p]or muito tempo se considerou necessário tomar a coletividade de credores como uma pessoa jurídica. Essa unidade dos credores é, contudo, uma pura construção téorica. Ela não é característica do direito germânico comum, do direito romano, e é também completamente estranha ao direito inglês. Seu reconhecimento legislativo parece ter ocorrido com a previsão da masse des créanciers e com o contrat d'union do code de commerce (art. 500. 527, 528). Mas mesmo a jurisprudência francesa interpreta a masse des créanciers simplesmente como a coletividade fática dos credores. [...] $\mathrm{Na}$ essência, a aparição da coletividade de credores se restringe à reunião dos direitos de propor a escolha de um administrador e ao fato de que as decisões tomadas pela maioria, nomeadamente sobre a celebração de concordata (Akkord), vinculam a minoria. Isso, porém, não é algo peculiar às pessoas jurídicas; as propostas e deliberações decorrem da união fática dos credores, da assembleia geral dos credores. A ideia de um corpo de credores não tem valor prático e é juridicamente insustentável. O surgimento da pessoa jurídica, contrariamente aos princípios básicos de direito, não visaria a se prolongar no tempo, mas buscaria a própria dissolução da coletividade; a pessoa jurídica não teria nenhuma existência independente e desvinculada dos credores; ela, como tal, não teria o que exigir do devedor; a ela não caberia nenhum patrimônio distinto daquele detido pelos credores."17

16 Charles Lyon-Caen, Louis Renault, Traité de Droit Commercial, tome 7, cit., n. 472, p. 510: "C'est une forme de association obligatoire, comme les associations syndicales".

17 OTto HAHN, Die gesammten Materialien zur Konkursordnung, Berlin, Deckers, 1881, p. 47: "Man hat lange Zeit für nöthig befunden, die Gesammtheit der Gläubiger als eine juristische Person zu fixieren. Solche Gläubigereinheit ist indes ein rein theoretisches Gebilde. Sie ist dem gemeinen deutschen Recht nicht eigenthümlich und dem römischen, wie auch dem englischen Rechte völlig fremd. Ihre gesetzliche Anerkennung scheint die in der masse des créanciers und dem contrat d'union des code de commerce (Art. 500, 527, 528) gefunden zu haben. Allein schon die französische Jurisprudenz interpretiert die masse des créanciers nur als die thatsächliche Gesammtheit der Gläubiger. [...]. Im wesentlichen reduziert sich das Auftreten der "Gläubigerschaft" als einer Gesammtheit auf das Vorschlagerecht für die Personen der Verwaltung und darauf, daß bei Beschlußfassungen, namentlich über einen Akkord, der Beschluß der Mehrheit die Minderheit bindet. Aber dies ist nichts der Personeneinheit Eigenthümliches, und die Vorschläge und Beschlüsse gehen von der thatsächlichen Vereinigung der Gläubiger, den Gläubigerversammlung aus. Die Idee eines Gläubigerkorps ist praktisch werthlos, juristisch nicht haltbar. Die Entstehung der Personeneinheit würde, entgegen den allgemeinen Rechtsgrundsätzen, nicht die Dauer, sondern die Aufhebung einer Gemeinschaft bezwecken; die Personeneinheit würde kein von den Personen der Gläubiger unabhängiges, selbständiges Dasein haben; sie, als solche, hat von dem Gemeinschuldner nichts zu fordern, es giebt kein Vermögensrecht, welches ihr verschieden von den einzelnen Gläubigern zustände." 


\subsubsection{LITISCONSÓRCIO}

Na Alemanha, defendeu-se o entendimento de que os credores não estariam vinculados por relações jurídicas de direito material, mas tão somente de direito processual. "Os credores concursais" - afirma Lothar Seuffert - "não mantêm relação diversa daquela existente entre diversos credores que tomem parte em um procedimento de execução especial. [...]. Da mesma forma que não surge entre os credores [...] que tomam parte nessa execução especial relações jurídicas de direito privado, estas tampouco surgem entre os credores concursais. A coletividade de credores, portanto, é litisconsórcio."18

Defende-se, nessa linha, que os credores formariam um litisconsórcio - ou comunhão processual (Verfahrengemeinschaft), como prefere Lent ${ }^{19}$ - a quem seriam outorgados específicos direitos e funções no âmbito do processo concursal; mas não subsistiriam entre os credores relações jurídicas de direito material. ${ }^{20}$

Essa teoria tem a vantagem de reconhecer que, com a falência, não há automática trasmissão de posições jurídicas de direito real. Os credores permanecem titulares de direito de crédito, que não passam à titularidade de uma comunhão. Entretanto, a construção jurídica é limitada, por não explicar o fundamento para que, de forma diversa ao que ocorre em litisconsórcios, seja possível, na coletividade de credores, a adoção de

18 LOTHAR SEUfFerT, Zur Geschichte und Dogmatik des Deutschen Konkursrechts, cit., p. 87: "Die Konkursgläubiger stehen unter einander nicht in anderer Beziehung, als die mehreren Gläubiger, welche bei einer einheitlich durchgeführten Spezialexekution beteiligt sind. [...]. Sowenig unter den mehreren Gläubigern, welche sich bei einer Spezialexekution [...] beteiligen, durch diese Beteiligung privatrechtliche Beziehungen entstehen, sowenig entstehen solche unter den Konkursgläubigern. Vielmehr ist die Gemeinschaft eine Streitgenossenschaft."

19 FRIEDRICH LENT, "Vorbemerkung zu §§ 61-70”, in Jaeger Kommentar zur Konkursordnung, Berlin, Walter de Gruyter, 1958, p. 829.

20 Entre os defensores desta linha teórica, pode-se mencionar também HANS PASQUAY. Entretanto, diversamente dos autores antes mencionados, PASQUAY considerava que a relação jurídica entre os credores seria de natureza bifronte. No que toca à participação no processo concursal, às decisões quanto a impugnações de créditos, quanto ao início e ao encerramento do processo, por exemplo, os credores estariam ungidos por relação jurídica de natureza processual, formando litisconsórcio ativo necessário, em que todos os integrantes são atingidos pelos efeitos da coisa julgada. Mas o autor reconhece que essa explicação seria insuficiente para esclarecer a participação dos credores na administração da massa e na sua liquidação, fenômenos estranhos ao direito processual. Assim, defende o autor que, sob o ponto de vista material, formase entre os credores também uma comunhão de interesses ("Die Rechtsstellung der Gläubigerversammlung im Konkurse und ihre Befugnisse (erstes Stück)”, in ZHR, vol. 65, 1909, pp. 409-442, pp. 432-433). 
decisões majoritárias que impliquem alteração da posição jurídica material de que os integrantes são titulares. $^{21}$

\subsubsection{COMUNHÃo}

É comum na doutrina brasileira a referência à coletividade de credores concursais por meio da expressão "comunhão de credores". A designação não é incorreta, mas é imprecisa, pois o termo "comunhão" é geralmente utilizado no direito brasileiro para designar uma específica forma de copropriedade distinta do condomínio, com origem no antigo direito germânico, ${ }^{22}$ e que se distingue do condomínio por quotas de tipo romano.

\subsubsection{COMUNHÃO DE TIPO GERMÂNICO E CONDOMÍNIO DE TIPO ROMANO}

A comunhão em mãos juntas, de origem germânica, distingue-se do condomínio por quotas, de tipo romano, por diversos aspectos. ${ }^{23}$ Os condôminos são titulares de posições jurídicas reais fracionárias sobre um bem; já na comunhão, há posição jurídica real única detida, em comum, e de forma grupal, pelos integrantes da comunhão. Ademais, embora seja possível que diversas pessoas sejam proprietárias em condomínio de diversos bens, as relações jurídicas reais não se relacionam. Cada condômino pode requerer, a todo tempo, a divisão de um dos bens sob propriedade comum (CC, art. 1320) e pode dispor de sua quota-parte relativa a um determinado bem, desde que respeitado o direito de preferência dos demais condôminos (CC, art. 504), mantendo-se o condomínio sobre os demais bens. $\mathrm{Na}$ comunhão, de modo diverso, pode ser objeto da copropriedade uma pluralidade de direitos, deveres, obrigações e pretensões que - na metáfora de Pontes de Miranda - ficam envoltos por uma "pele patrimonial", ${ }^{24}$ uma união que não se altera, a despeito da alteração de suas partes componentes. Assim, cada integrante da comunhão só pode dispor de sua quota-parte sobre todos os bens integrantes da comunhão ou requerer sua divisão, mas não

\footnotetext{
21 SABINE VORWERK, Von der typenübergreifenden Gemeinschaft der insolvenzbeteiligten Gläubiger, cit., pp. 120-122.

22 Trata-se do instituto da Gesamthand. Sobre o assunto, cf. HERBERT WIEDEMANN, Gesellschaftsrecht I - Grundlagen, C. H. Beck, München, 1980, §5 I 2, pp. 242-291; KARL LARENZ, Allgemeiner Teil des Bürgerlichen Rechts, $9^{\mathrm{a}}$ ed. atual. por MANFRED WOLF, C. H. Beck, München, 2004, §9 IV 2, Rn. 72-80, pp. 167-170. Entre nós, cf. ERASMO V. A. E N. FrançA, Ensaio sobre a Sociedade em Comum, Tese de LivreDocência apresentada à Faculdade de Direito da Universidade de São Paulo, São Paulo, 2011, pp. 72-78.

23 DARCy BeSSONE, Direitos Reais, $2^{\text {a }}$ ed., São Paulo, Saraiva, 1996, pp. 79-82.

24 F. C. Pontes De Miranda, Tratado de Direito Privado, Tomo 5, Rio de Janeiro, Borsoi, 1955, $\S 594$, p. 354.
} 
alienar uma quota-parte relativa a um bem determinado. Exemplos de comunhão no direito brasileiro são oferecidos pelo regime de bens no matrimônio, ${ }^{25}$ pelo regime patrimonial da sociedade em comum ${ }^{26}$ e pelas áreas comuns nos condomínios edilícios.

\subsubsection{A CONCEPÇÃO DE ROCCO: CREDORES COMO TITULARES EM MÃO COMUM}

No âmbito concursal, portanto, afirmar que os credores estariam em comunhão significa afirmar que são titulares em conjunto de determinado patrimônio. Esse entendimento foi esposado por Alfredo Rocco. Para o autor, a falência exigiria que todos os direitos de crédito fossem exercidos de forma coletiva e contemporânea, e que nenhum dos credores tomasse a frente em relação aos demais. Por conta disso, com o início do procedimento concursal, os credores seriam reunidos por lei em um grupo que se tornaria titular, em mão comum, dos créditos antes detidos individualmente por cada credor. Em comunhão, teriam, também, o direito de penhora sobre o patrimônio do devedor; a posse e a administração de seu patrimônio; o direito de exigir a restituição ao patrimônio de tudo que foi disposto em infração à regra de igualdade entre os credores; e o direito de representar ativa e passivamente o devedor em demandas judiciais. ${ }^{27}$

\subsubsection{CRÍTICAS}

Essa concepção foi objeto de severas críticas. Segundo Roberto Sacchi, a doutrina foi rejeitada na Itália pelo fato de que a mancomunhão estabelecida entre os credores não teria um patrimônio próprio, pois os direitos de crédito permanecem sob a titularidade de cada um dos credores, e é justamente daí que decorre sua legitimidade para participar do procedimento. ${ }^{28}$ No Brasil, Pontes de Miranda assim se manifestou a respeito da teoria de Rocco: "[a] teoria da comunhão pro indiviso que existiria no concurso de credores é falsa: confunde concorrência com comunhão; vê comunhão, por exemplo, nas pretensões e ações que se computaram nos bens sujeitos a concurso de credores, e não há comunhão, há

\footnotetext{
25 "A comunhão resultante do matrimônio difere do condomínio propriamente dito, porque nela os bens formam a propriedade de mão comum, cujos titulares são ambos os cônjuges”. STJ, REsp n. 3710-0RS, 4ª T., Rel. Min. ANTÔNIO TORREÃO BrAZ, v.m., j. 21.06.1995, DJ 28.08.1995.

26 ERASMO V. A. E N. FrANÇA, Ensaio sobre a Sociedade em Comum, cit., p. 150.

27 AlfRedo RocCO, Il Concordato nel Fallimento e prima del Fallimento, Torino, Fratelli Bocca, 1902, n. 77, pp. 156-157.

28 ROBERTO SACCHI, Il principio di maggioranza nel concordato e nell'amministrazione controllata, cit., pp. 16-17.
} 
possível sucessão por dois ou mais credores nos bens ou produto dos bens sujeitos ao concurso de credores. [...] Há coletividade, concorrência, no concurso de credores; não há comunhão". 29

No atual sistema concursal brasileiro, não há entre os credores nenhuma cotitularidade de direitos reais ou obrigacionais que possa ser assemelhada à comunhão. Até que seja realizado pagamento no âmbito de plano de recuperação judicial, ou que seja promovida a liquidação dos ativos em falência, nenhum dos credores adquire propriedade sobre os bens do devedor; todos mantêm, durante todo o procedimento concursal, seu direito de crédito e exercitam os direitos a ele pertinentes de forma individual e autônoma.

\subsubsection{COMUNHÃO DE INTERESSES}

$\mathrm{Na}$ atualidade, a teoria prevalecente na Alemanha, na Itália e no Brasil para definir a natureza da relação jurídica estabelecida entre a coletividade de credores é a de que estes formam uma comunhão de interesses (Interessengemeinschaft), a partir do momento em que é iniciado o procedimento concursal.

\subsubsection{A "DESCOBERTA" JURÍDICA DE JHERING}

A comunhão de interesses é uma figura jurídica mencionada pela primeira vez por Rudolph von Jhering. Em um estudo sobre os efeitos das relações jurídicas sobre terceiros, Jhering visualizou nas fontes romanas uma nova categoria jurídica, ${ }^{30}$ nela identificando o fenômeno da comunhão de interesses. ${ }^{31}$ Jhering busca demonstrar que, em diversas situações retratadas nas fontes romanas, ações de uma pessoa impõem efeitos jurídicos a

29 F. C. Pontes De Miranda, Tratado de Direito Privado, Tomo 27, Rio de Janeiro, Borsoi, 1960, $\S 3210$, p. 41.

30 No primeiro período de sua produção científica, JHERING comparava a ciência jurídica à química e buscava encontrar os elementos jurídicos essenciais, a partir dos quais novos conceitos, ainda desconhecidos, pudessem ser construídos (KARL LARENZ, Methodenlehre der Rechtswissenschaft, 6. ed., Berlin/Heidelberg, Springer, 1991, p. 27). Nas palavras de Jhering: "A ciência é capaz de criar novos conceitos e normas a partir da combinação de diferentes elementos: os conceitos jurídicos são produtivos, eles se unem e geram novos conceitos" (RUDOLPH VON JHERING, Der Geist des römischen Rechts auf den verschiedenen Stufen seiner Entwicklung, Bd. 1, Leipzig, Breitkopf und Härtel, 1852, p. 29: "Durch Kombination der verschiedenen Elemente kann die Wissenschaft neue Begriffe und Rechtssätze bilden; die Begriffe sind productiv, sie paaren sich und zeugen neue").

$31 \quad$ RUDOLPH VON JHERING, "Die Reflexwirkungen oder die Rückwirkung rechtlicher Thatsachen auf dritte Personen", in Jahrbücher für die Dogmatik des heutigen römischen und deutschen Privatrechts, vol. 10, 1871, pp. 245-354, p. 273. 
outra pessoa, mesmo que o agente não pretenda a ocorrência desses efeitos. Os efeitos podem ser positivos, como é o caso do achado de tesouro em prédio alheio, que torna o dono do prédio proprietário de metade do valor do bem encontrado, mesmo contra a sua vontade. Podem também ser negativos, como é o caso da derrelicção de um bem comum por um dos condôminos. ${ }^{32}$ Entre os exemplos de situações que geram efeitos reflexos, Jhering vê na Lex Rhodia ${ }^{33}$ um caso de peculiar relevância. A lei, que deu origem à regra de direito marítimo da avaria grossa (CCom, art. 774), determina que, caso uma embarcação enfrente grave risco de naufrágio, fica o capitão do navio autorizado a lançar ao mar as mercadorias transportadas. Caso o naufrágio seja evitado, e a embarcação alcance o porto de destino com mercadorias sãs, aqueles que tiveram suas cargas sacrificadas devem ser ressarcidos por aqueles que tiveram suas cargas poupadas. ${ }^{34}$ Para Jhering, o fundamento jurídico dessa regra residiria na circunstância de que, entre os mercadores, estabelece-se obrigatoriamente uma comunhão de interesses, em que o sacrifício individual pode ser exigido para promoção do interesse comum. Entretanto, por respeito à equidade, os custos devem ser repartidos entre aqueles que tenham sido beneficiados. $^{35}$ Nessa regra estaria, para Jhering, a expressão de um princípio geral de direito que poderia ser aplicado por analogia a outras situações semelhantes. ${ }^{36}$

\subsubsection{A SISTEMATIZAÇão PROPOSTA POR PHILliP HECK}

Ao analisar a avaria grossa, Philipp Heck levou adiante os estudos de Jhering acerca da comunhão de interesses. Para Heck, a categoria "descoberta" por Jhering teria uma aplicação mais abrangente do que o próprio Jhering concebeu. Há diversas figuras jurídicas que situam forçadamente diversos sujeitos em condição de reciprocamente influenciarem as esferas jurídicas alheias, e o fundamento jurídico para essa situação não é o condomínio, e aí reside o traço característico da comunhão de interesses. ${ }^{37}$ No condomínio, a copropriedade faz que a atuação de um dos condôminos sobre a coisa afete diretamente os

\footnotetext{
$32 \quad$ Id., p. 295.

33 Sobre a origem da Lei Rhodia, cf. R. BENEDICT, "The Historical Position of the Rhodian Law", in Yale L. J., vol. 18, 1909, pp. 223-242.

34 cf. REINHARD ZIMMERMANN, The Law of Obligations - Roman Foundations of the Civilian Tradition, Oxford, University Press, 1996, pp. 406-412.

35 RUDOLPH VON JHERING, "Die Reflexwirkungen oder die Rückwirkung rechtlicher Thatsachen auf dritte Personen", cit., p. 348.

$36 \quad$ Id., p. 348.

37 PHILIPP HECK, Das Recht der großen Haverei, Berlin, H.W. Müller, 1889, p. 557.
} 
demais. Mas há situações nas quais os integrantes de uma coletividade não são coproprietários de um bem, e mesmo assim, permanecem sujeitos aos efeitos da atuação dos demais. A situação é em tudo semelhante a um condomínio (Gemeinschaft nach Bruchteilen), mas falta a propriedade em comum, e a comunhão é dita somente de interesses (Interessengemeinschaft). ${ }^{38}$

Heck, contudo, discordou da denominação dada à figura por Jhering e buscou precisá-la. Entre as figuras descritas como comunhão de interesses, haveria, segundo Heck, que mais tarde viria a ser o maior representante da jurisprudência dos interesses, ${ }^{39}$ certas situações em que os interesses das partes são paralelos, bem como outras figuras, contrapostas àquelas situações, em que os interesses das partes são conflitantes. Dessa forma, Heck prefere adotar a expressão "coligação de interesses" (Interessenverbindung) para representar o gênero composto pelas situações de comunhão de interesses em sentido estrito (Interessengemeinschaft im engeren Sinn) e pelas situações de conflito de interesses (Interessenkonflikt).

Com essa diferenciação, Heck ampliou o potencial explanatório da teoria proposta por Jhering. A necessidade de intervenção jurídica nas situações de interesses paralelos é diversa daquela exigida quando os interesses das partes são conflitantes: “[q]uando há uma comunhão de interesses em sentido estrito, praticamente não é necessária a intervenção do ordenamento jurídico. Atitudes que beneficiam a todos serão sempre adotadas, enquanto aquelas que a todos prejudicam serão sempre evitadas. Esse estado é desejável. Somente quando ele está ausente é que se deve temer pela ocorrência de perdas econômicas. Pois quando uma atitude beneficia a um e prejudica a outro, ou quando até beneficia a todos, mas exige sacrifícios de um, eximindo aqueles que permanecem passivos, então o indivíduo não mais se guiará pela consideração do interesse comum. Ele tomará atitudes que prejudicam a todos, porque lhe trazem vantagens pessoais; ele postergará a medida que a todos beneficia, com a esperança de que outro a adote. O egoísmo o guiará a um

\footnotetext{
$38 \quad$ Há diversas situações em que esta configuração se dá independentemente da copropriedade: (i) nas obrigações solidárias, o devedor, pagando o total da dívida a um dos credores solidários, extingue seu débito em relação aos demais credores, que agora terão de se voltar contra o credor acipiente; (ii) na composse, todos os possuidores podem defender a posse comum, ainda que não sejam titulares da propriedade; (iii) nas garantias de graus sucessivos, os credores garantidos com prioridade inferior terão sua garantia diminuida com a excussão da garantia de pelo credor com garantia de grau superior; e (iv) na coexistência de direitos reais de natureza diversa, como é o caso do usufruto, as ações praticadas sobre o bem se refletem na esfera jurídica do outro titular de direito real. PHILIPP HECK, Das Recht der großen Haverei, cit., pp. 568-575.

39 KARL LARENZ, Methodenlehre der Rechtswissenschaft, cit., p. 49.
} 
comportamento economicamente inadequado, que, visto em conjunto, mais prejudica do que beneficia. Por conta disso, os desejos das partes tomarão rumos diversos. O conflito de vontades reflete a contraposição de interesses. Para essa situação, é aplicável a paremia communio est mater rixarum. A intervenção do direito é dirigida a superar esse estado." 40

Para tanto, o ordenamento jurídico pode se valer de mecanismos diversos, como a restrição da atuação privada que contrarie o interesse da comunhão, a concessão de valor compensatório que neutralize o conflito de interesses, e o reconhecimento de direitos e deveres específicos a fim de evitar a adoção de comportamentos que prejudiquem o interesse comum. ${ }^{41}$ Por outro lado, deve estimular a adoção de medidas que a todos beneficiem. Além disso, a situação de coligação de interesses justifica que o ordenamento jurídico atribua à maioria o direito de impor sua vontade à minoria. ${ }^{42}$

No procedimento concursal, a insuficiência patrimonial do devedor gera uma especial coligação de interesses entre seus credores. Essa coligação, afirma Heck, é pautada pelo pensamento de que "as consequências economicamente negativas de uma ação individual e motivada por interesses egoísticos de cada credor devem ser evitadas". 43 Há uma situação que Heck considera de conflito de interesses, enfrentada pelo ordenamento jurídico por meio da limitação do exercício de direitos individuais, por meio da organização de um procedimento para a ação em comum e por meio da atribuição à maioria do direito de conceder moratória ao devedor. ${ }^{44}$

\footnotetext{
$40 \quad I d$. , p. 566-567: "Wenn eine Interessengemeinschaft im engsten Sinne vorliegt, so ist kaum Anlaß zu einem Eingreifen der Rechtsordnung gegeben. Für Alle gleich vorteilhafte Handlungen werden stets vorgenommen, für Alle gleich nachtheilige Handlugen werden stets vermieden werden. Dieser Zustand ist durchaus wünschenswerth. Erst wenn er fehlt, sind wirthschaftliche Verluste zu befürchten. Denn wenn die Handlung dem Einen nützt, dem Anderen schadet, oder zwar Allen nützt, aber dem Handelnden Opfer auferlegt, von denen die passiv Betheiligten frei bleiben, so wird der Einzelne sich nicht mehr von der Berücksichtigung der Gesammtinteressen leiten lassen. Er wird im ganzen schädliche Handlungen vornehmen, weil sie ihm persönlich Vortheil bringen; er wird im ganzen nützliche Handlungen hinausschieben in der Hoffnung, daß ein Anderer sie vornimmt. Der Egoismus wird ihn zu einem Verhalten nöthigen, das wirthschaftlich unzweckmäßig ist, das, in seiner Gesammtwirkung betrachtet, mehr schadet als nützt. Deshalb werden die Wünsche der Betheiligten eine verschiedene Richtung annehmen. Der Willenskonflikt wird dem Gegensatze der Interessen entsprechen. Für solche Sachlagen trifft die Parömie zu: communio est mater rixarum. Der Eingriff des Rechts ist deshalb gerichtet auf Beseitigung dieses Zustandes."

$41 \quad I d .$, p. 567.

$42 \quad I d .$, p. 582.

$43 \quad I d .$, p. 573.

$44 \quad I d .$, p. 582.
} 


\subsubsection{RECEPÇÃO JURISPRUDENCIAL E DOUTRINÁRIA}

A proposta de separar as comunhões de interesse em sentido estrito das coligações de interesses conflitantes, proposta por Heck, não foi adotada na doutrina que se seguiu e que se ateve à expressão "comunhão de interesses". De toda forma, sua influência teórica foi considerável. Em 1914, o Tribunal do Reich alemão reconheceu, pela primeira vez, a teoria da comunhão de interesses, ao analisar o caso de um produtor de açúcar que vendera parte de sua produção futura a diversos compradores. ${ }^{45}$ Não obstante a obrigação de entregar sacas de açúcar ser obrigação genérica, o contrato especificava que deveria ser entregue o açúcar produzido pelo vendedor, de qualidade especial não disponível no mercado, configurando-se, assim, uma dívida de gênero limitado. No ano de 1911, por conta do clima seco na região de produção do açúcar, apenas 993 sacas daquela espécie foram produzidas, ao passo que o vendedor se comprometera a entregar 2160 sacas. O vendedor considerou que a sua obrigação se tornara parcialmente impossível e, por conta disso, promoveu um rateio entre os compradores, para satisfazê-los parcialmente, de forma proporcional à quantidade que haviam comprado. Um dos compradores, porém, pretendeu receber todos as sacas que havia adquirido, pois, físicamente, elas estavam ainda na fábrica do vendedor, razão pela qual não se poderia invocar a impossilidade de sua entrega.

O Tribunal do Reich negou a pretensão do comprador. Segundo a decisão, os credores de uma dívida genérica limitada estão em uma situação de comunhão de interesses (Interessengemeinschaft). Se ocorrer impossibilidade parcial, e o devedor satisfizer integralmente o primeiro credor, os últimos terminarão sem receber nada. Ao seguir o procedimento de rateio, o vendedor agiu corretamente e concretizou seu dever de cumprir a obrigação de boa-fé (nos termos do §242 do BGB).

\subsubsection{RECONHECIMENTO DA COLETIVIDADE DE CREDORES COMO COMUNHÃO DE INTERESSES}

Na doutrina, de diversos trabalhos doutrinários na Alemanha ${ }^{46}$ e na Itália ${ }^{47}$ consideram que os credores formam uma comunhão de interesses. Já na jurisprudência, a aplicação da

\footnotetext{
$45 \quad$ RG, II. Zivilsenat. j. 03.02.1914, in RGZ 84, 125.

46 HANS WÜRDINGER, Theorie der schlichten Interessengemeinschaft, Stuttgart, Ferdinand Enke, 1934, pp. 63-68; RUdOLF MüLlER-ERZBACH, Die Rechtswissenschaft im Umbau, München, Max Hueber, 1950,
} 
teoria da comunhão de interesses ao direito falimentar ocorreu pela primeira vez com decisão do Tribunal Superior Alemão $(B G H)$ datada de 1991. Discutia-se, no caso, se há alguma relação jurídica entre os credores de uma empresa que busque uma reorganização extrajudicial (não regulada na Alemanha). Caso a resposta fosse positiva, argumentava-se que esses credores estariam vinculados aos demais e seriam reciprocamente destinatários de deveres de lealdade e de cooperação. O Tribunal negou que houvesse entre os credores uma relação jurídica antes de iniciado o procedimento concursal, mas afirmou que, com o início do procedimento, instaurar-se-ia entre eles uma comunhão de interesses que lhes imporia deveres recíprocos de lealdade e de consideração. ${ }^{48}$

\subsubsection{A COMUNHÃO de INTERESSES NO DIREITO BRASILEIRO E A NATUREZA JURÍDICA DA RELAÇÃO ENTRE OS CREDORES}

No Brasil, a figura da comunhão de interesses não é desconhecida. O Decreto-Lei n. 781, de 12.10.1938, com rigor técnico, previa em seu artigo $1^{\circ}$ que "os empréstimos por obrigações ao portador (debêntures) contraidos pelas sociedades anônimas, ou em comandita por ações, ou pelas autorizadas por leis especiais, criarão, quando tal condição constar do manifesto da sociedade e do contrato devidamente inscrito, uma comunhão de interesses entre os portadores dos títulos da mesma categoria, a saber, emitidos com fundamento no mesmo ato, subordinados às mesmas condições de amortização e juros, e gozando das mesmas garantias."

Tal qual os debenturistas, também os credores não são coproprietários de direitos reais ou obrigacionais - em ambas as hipóteses, cada credor é titular de seu crédito -, mas estabelece-se entre os integrantes uma comunhão de interesses. ${ }^{49} \mathrm{O}$ fato de que os interesses dos credores possam ser divergentes e concorrentes não afasta a possibilidade de

pp. 91-97; GÜNTHER WÜST, Die Interessengemeinschaft: ein Ordnungsprinzip des Privatrechts, Frankfurt a.M./Berlin, Alfred Metzner, 1958, p. 45; GÖTZ HUECK, Der Grundsatz der gleichmässigen Behandlung im Privatrecht, München/Berlin, C. H. Beck, 1958, p. 138; HERBERT WIEDEMANN, Gesellschaftsrecht I Grundlagen, cit., \$1 I 2, p. 13; PETER GOTTWALD, "Die Interessengemeinschaft der Gläubiger eines insolventen Schuldners", in WALTER J. HABSCHEID (et. all.) (org.), Freiheit und Zwang - Festschrift zum 60. Geburtstag von Prof. Dr. iur. Dr. phil. Hans Giger, Bern, Stämpfli, 1989, pp. 195-211.

47 FrAnCESCO GALGANO, La forza del numero e la legge della ragione: storia del principio di maggioranza, Bologna, Mulino, 2007, p. 207.

$48 \quad$ BGH, IX ZR 178/91, j. 12.12.1991.

49 Erasmo V. A. e N. FrançA, in Francisco S. De Souza Junior, Antônio Sérgio A. DE M. PITOMbo (coord.), Comentários à Lei de Recuperação de Empresas e Falência, cit., p. 187, nota 129: "É lícito falar, assim, em uma comunhão de interesses entre os credores [...]." (grifos no original) 
designar a coletividade como comunhão de interesses. ${ }^{50}$ De fato, a objeção é pertinente, pois a designação "comunhão de interesses" para uma situação de conflitos de interesse pode ser considerada contraditória. Tanto assim que Phillip Heck preferia a denominação "coligação de interesses". A categoria dogmática, contudo, não tem seu fundamento na efetiva conformação de interesses individuais das partes, mas sobretudo, como se nota no estudo pioneiro de Jhering, na circunstância de que, nessas coletividades, é dado a um dos integrantes influir na esfera jurídica alheia.

\subsection{DEVER DE LEALDADE ENTRE OS CREDORES}

Ao integrar uma comunhão de interesses, um credor pode influir nas esferas jurídicas dos demais credores integrantes da comunhão. Entretanto, a participação da comunhão não pressupõe a celebração de contrato. Ela é imposta por lei. Nessa situação, pode-se questionar se o credor está livre para perseguir seus interesses da forma como preferir, sem vinculação com os demais credores, ou se é destinatário de um dever de lealdade em relação à comunhão e aos demais credores.

\subsubsection{DESENVOLVIMENTO HISTÓRICO DO DEVER DE LEALDADE SOCIETÁRIO}

O dever de lealdade é uma figura jurídica doutrinária e jurisprudencial desenvolvida no direito alemão, ${ }^{51}$ que vem sendo incorporada aos direitos italiano e português e que, recentemente, foi considerada como um dever presente no direito societário brasileiro. ${ }^{52}$

\subsubsection{PRIMEIRo PERÍODO: A JURISPRUdÊNCIA A SERVIÇO DO PODER MAJORITÁRIO}

\footnotetext{
50 ERASmo V. A. E N. FranÇA (“A Assembléia-Geral de Credores na Nova Lei Falimentar”, in Temas de Direito Societário, Falimentar e Teoria da Empresa, São Paulo, Malheiros, 2009, pp. 7-26, p. 9, nota 7)

51 O que levou ANTÓNIO MENEZES CORDEIRO a afirmar que, sobre o assunto, "[n]enhuma outra literatura - nem mesmo a anglo saxónica! - dispõe de elementos jurisprudenciais que se aproximem, sequer, dos alemães" (“A Lealdade no Direito das Sociedades”, in ROA, vol. 3, ano 66, 2006, pp. 1033-1066, p. 1036). Note-se, contudo, que a situação é diversa no que toca aos deveres de lealdade impostos aos administradores, que tiveram na doutrina e na jurisprudência anglo-saxônica maior desenvolvimento, e hoje influenciam decisivamente a doutrina continental, inclusive alemã (HOLGER FLEISCHER, "Legal Transplants in European Company Law - The Case of Fiduciary Duties”, in ECFR, vol. 2, 2005, pp. 378-397).

52 Marcelo V. VON ADAMEK, Abuso de Minoria em Direito Societário (Abuso das Posições Subjetivas Minoritárias), Tese de Doutorado apresentada à Faculdade de Direito da Universidade de São Paulo, São Paulo, 2010, p. 142. Nas páginas 79-105, o autor analisa o dever de lealdade na Alemanha.
} 
As condificações societárias alemãs não mencionaram o dever de lealdade, e, em conformidade com o pensamento liberal predominante naquele período, a jurisprudência do Tribunal do Império (Reichsgericht) decidiu pela total desvinculação dos sócios em relação aos demais. Até depois da Segunda Guerra Mundial, o direito societário alemão é considerado um "exemplo não muito belo da sustentação da força pelo direito". ${ }^{53}$ Como exemplo mais evidente dessa orientação jurisprudencial, Herbert Wiedemann cita a decisão do Tribunal do Império no caso Hibernia, na qual se afirmou que todos aqueles que adquirem ações devem estar cientes de que, por conta do princípio majoritário, o destino da sociedade será decidido pela maioria. Mesmo que a decisão da maioria prejudique seus interesses, os acionistas minoritários devem com isso se conformar. ${ }^{54}$

\subsubsection{SEgundo PERÍOdo: O PROGRESSIVO ALARgamento Do DEVER DE LEALDADE}

Inicia-se, então, um movimento doutrinário lento e progressivo, primeiro calcado pelo reconhecimento de que o princípio da boa-fé também teria aplicação ao direito societário. ${ }^{55}$ Mas a aplicação do dever de boa-fé diretamente às relações societárias era considerada imprecisa, e a doutrina passou a caminhar para o reconhecimento de deveres específicos de lealdade (Treupflichten) ${ }^{56}$ no âmbito societário. Nessa linha, Alfred Hueck vê, no relacionamento interpessoal dos sócios, a fonte de deveres específicos de cuidado e de consideração recíprocos e considera a existência de deveres de lealdade nas sociedades de pessoas, mas não nas sociedades de capital. ${ }^{57}$ Segundo o pensamento predominante àquela época, nas sociedades de capitais, diferentemente do que ocorre nas sociedades de pessoas, subsistiriam relações jurídicas apenas entre os sócios e a sociedade, mas não entre os sócios reciprocamente.

$53 \quad$ HERBERT WIEDEMANN, Gesellschaftsrecht I - Grundlagen, cit., §8 I 2, p. 409: "Insgesamt bietet die Entwicklung bis lange nach dem zweiten Weltkrieg ein für Deutschland nicht untypisches, aber wenig schönes Beispiel der Unterstützung der Macht durch das Recht”.

$54 \quad I d$., $\$ 8$ I 2, p. 409. Um ponto fora da curva nesta primeira fase da jurisprudência é representado pelo julgamento do "Caso Victoria", em que o Tribunal do Reich decidiu que, do poder da maioria de impor uma deliberação à minoria, e, com isso, mediatamente, dispor dos ativos reunidos no patrimônio social, resulta um dever societário à maioria de considerar o interesse conjunto dos sócios, considerando, inclusive os nteresses legítimos da minoria, sem limitá-los além do necessário (RGZ, 132, 149). cf. WoLfRAM TIMM, "Zur Sachkontrolle von Mehrheitsentscheidungen im Kapitalgesellschaftsrecht”, in ZGR, n. 3, 1987, pp. 403-442, pp. 404-405.

55 António Menezes CoRdeIRo, “A Lealdade no Direito das Sociedades”, cit., p. 1057.

56 O termo pode ser grafado também sob a forma "Treuepflichten".

57 António MenEZes CordeIRO, “A Lealdade no Direito das Sociedades”, cit., p. 1051 
Entretanto, a doutrina passa a questionar, progressivamente, a disparidade de tratamento, indagando se não estariam também os integrantes de sociedades de capital sujeitos a deveres recíprocos de lealdade. ${ }^{58}$

No chamado caso "ITT", o Tribunal Federal Alemão (BGH) respondeu afirmativamente à questão, mas considerou, sobretudo, a circunstância de que as sociedades limitadas $(G m b H)$ - que constituem sociedades de capital por seu tipo societário - poderiam ser contratualmente conformadas de maneira personalista, gerando deveres de lealdade entre os sócios. ${ }^{59}$ Mas, em uma decisão pouco posterior, o BGH analisou a existência de deveres de lealdade nas sociedades anônimas, e posicionou-se de forma oposta, afirmando que "não há violação a um dever de lealdade societário, pois uma ligação entre os acionistas que ultrapasse os princípios gerais dos $\S \S 226$ [proibição de ato emulativo], 242 [dever de boa-fé], 826 [responsabilidade civil] do BGB não existe, ou, ao menos, não fundamenta uma responsabilidade societária. A pertinência conjunta a uma sociedade anônima não fundamenta, por si, relações jurídicas bilaterais [entre os acionistas], das quais se pudesse extrair uma responsabilidade como essa". ${ }^{60}$

A reação da doutrina foi capitaneada por Marcus Lutter. Para o autor, seria necessário abandonar a expressão "dever de lealdade" (Treupflicht), que poderia levar a indevidas associações com a cláusula geral de boa-fé (Treu und Glauben), e substituí-la pelos conceitos de dever de promoção do fim social nas associações em sentido amplo (mitgliedschaftliche Förderpflicht), dever de não prejudicar a associação e de lhe ser leal (Unterlassungs- und Loyalitätspflicht) e dever de consideração para com os demais membros da associação (Rücksichtspflichten). ${ }^{61}$ Para Lutter, o fundamento desses deveres

58 A história do dever de lealdade entre os acionistas foi tratada com profundida em estudo monográfico de PETER STELZIG, Zur Treuepflicht des Aktionärs unter besonderer Berücksichtigung ihrer geschichtlichen Entwicklung, Tese de Doutorado apresentada à Faculdade de Direito de Münster, Münster, 2000.

$59 \quad$ BGH, II ZR 23/74, j. 05.06.1975.

60 BGH, II ZR 61/74, j. 16.02.1976: "Die Verletzung einer gesellschaftsrechtlichen Treuepflicht scheidet als Anspruchsgrundlage ebenfalls aus, weil eine solche im Sinne einer über die allgemeinen Rechtsgrundsätze der $\S \S 226,242,826$ BGB hinausgehenden Bindung zwischen Aktionären im allgemeinen nicht besteht oder jedenfalls keine Haftung für Vermögensnachteile jenseits des innergesellschaftlichen Bereichs ausgelösen kann, wie sie hier mit der Klage geltend gemacht werden. Die gemeinsame Zugehörigkeit zu einer Aktiengesellschaft begründet für sich allein keine gegenseitigen Rechtsbeziehungen, aus denen sich eine solche Haftung herleiten ließe".

61 MARCUS LUTTER, "Theorie der Mitgliedschaft - Prolegomena zu einem Allgemeinen Teil des Korporationsrechts", in AcP, vol. 180, 1980, pp. 84-159, pp. 109-130. 
não seria encontrado no dever de boa-fé, mas no fato de que, em todas as associações voluntárias, as partes se reúnem para a persecução de um fim comum. ${ }^{62}$ Por conta disso, tanto nas associações sem fim lucrativo como nas sociedades de pessoas e nas sociedades de capital, deve ser reconhecida a existência de deveres entre os associados, bem como entre os associados e a associação. A diferença entre a intensidade e a densidade desses deveres, por sua vez, deveria ser determinada por meio da análise da forma societária, de sua estrutura real, do fim societário e da capacidade de influência concreta do associado. ${ }^{63}$

O movimento teve repercussão e levou a uma alteração da jurisprudência do BGH. Com o julgado "Linotype", em 1988, o BGH passou a reconhecer que, também na sociedade anônima, o sócio majoritário tem a posisibilidade de prejudicar os demais acionistas, por meio do exercício de influência sobre a administração da sociedade. Dessa forma, considerou que não faria sentido negar a existência de deveres de lealdade entre acionistas, mas aceitar a existência desses deveres caso a sociedade simplesmente passasse a adotar a forma de sociedade de pessoas, mantendo os mesmos sócios e a mesma conformação contratual. Entretanto, pontuou o BGH, deveres de lealdade seriam impostos somente aos acionistas majoritários, não aos acionistas minoritários. ${ }^{64}$

Essa fronteira também viria a ser criticada pela doutrina. Questionou-se a justificativa para considerar que os acionistas minoritários não estariam sujeitos a deveres de lealdade quando tenham o poder de vetar uma operação essencial para a companhia, ou quando assumam o poder de formar a vontade social por estar o acionista majoritário impedido de votar.

Um caso concreto não tardou a ser julgado, e o BGH alterou, novamente, seu posicionamento. No caso "Girmes", ${ }^{65}$ uma sociedade anônima ingressou em estado de crise. A diretoria, então, negociou um plano de saneamento extrajudicial com os principais credores e o submeteu à apreciação dos acionistas. O plano previa a redução do capital na proporção de $5 / 2$ e a subsequente emissão de novas ações, mas não foi aprovado. Um dos

62 MARCuS LutTer, "Theorie der Mitgliedschaft - Prolegomena zu einem Allgemeinen Teil des Korporationsrechts", cit., p. 104.

63 MARCUS LuTtER, "Theorie der Mitgliedschaft - Prolegomena zu einem Allgemeinen Teil des Korporationsrechts", cit., p. 111.

$64 \quad$ BGH, II ZR 75/87, j. 01.02.1988.

65 BGH, II ZR 205/94, j. 20.03.1995. 
acionistas, considerando que a redução prejudicava demasiadamente os interesses dos acionistas minoritários, solicitou e obteve procurações que lhe outorgavam um poder de bloqueio à redução do capital e exerceu os direitos de voto dos minoritários para impedir a operação. Sem a aprovação do plano de saneamento, a sociedade ingressou com processo de concordata, depois convolada em falência. $\mathrm{O} \mathrm{BGH}$, nesse caso, considerou que o acionista minoritário também era destinatário de um dever de lealdade em relação aos demais acionistas, o que lhe obrigava a exercer seus direitos societários, em especial de administração e fiscalização, com adequado respeito aos interesses societários dos demais; por conta desse dever, não podia o acionista, mesmo que minoritário, evitar, por motivos egoísticos, a aprovação de um plano de saneamento racional e desejado pela maioria. ${ }^{66}$

Em um julgado de 2010, conhecido como "Sanear ou Sair" (Sanieren oder Ausscheiden), o BGH reafirmou o entendimento de que o acionista minoritário está sujeito a deveres de lealdade. Tratava-se, mais uma vez, de uma sociedade insolvente, em que os sócios eram ilimitadamente responsáveis. Caso a sociedade fosse liquidada, cada sócio solidariamente responsável teria de arcar com dívidas na ordem de 130\% do valor nominal do capital social. Foi proposta, então, uma redução do capital social em 99,9\%, com posterior emissão de novas ações para os sócios que desejassem investir novos recursos para a continuidade da empresa. Ao mesmo tempo, a deliberação social determinou que os sócios que não desejassem subscrever novas ações seriam excluídos da sociedade e teriam de pagar quantia equivalente a $120 \%$ do valor nominal do capital social, quantia ainda inferior àquilo a que estariam obrigados na falência. $\mathrm{O}$ BGH, nessa hipótese, entendeu que o acionista minoritário teria um dever de votar favoravelmente ao plano, que não o prejudica em comparação com a hipótese de falência, e, ao mesmo tempo, permite o saneamento empresarial. $^{67}$

Percebe-se, com isso, que o dever de lealdade teve seu campo de atuação progressivamente ampliado; primeiro, com sua aplicação às sociedades de pessoas; depois, com sua aplicação às sociedades de capital com conformação personalista; posteriormente, para todas as sociedades de capital, mas não para os sócios minoritários; por fim, com o reconhecimento de que mesmo sócios minoritários em sociedades de capital são

66 Sobre esse julgado, cf. MARCUS LUTTER, "Das Girmes-Urteil”, in JZ, n. 21, 1995, pp. 1053-1056; LUDWIG HÄSEMEYER, “Obstruktion gegen Sanierung und gesellschaftrechtliche Treupflichten”, in ZHR, vol. 160, 1996, pp. 109-132.

67 BGH, II ZR 240/08, j. 19.10.2009. 
destinatários de um dever de lealdade para com a sociedade e seus sócios. Como consequência, também o fundamento dogmático dos deveres de lealdade foi revisto ao longo do tempo.

\subsubsection{FUNDAMENTO DOGMÁTICO DO DEVER DE LEALDADE SOCIETÁRIO}

Diferentes são os fundamentos indicados para o dever de lealdade. A primeira corrente, como se mencionou, identificava na especial relação de confiança entre os sócios de sociedades de pessoas o fundamento do dever de lealdade. ${ }^{6}$ Conforme essa teoria, permaneceria limitado o alcance do dever de lealdade às sociedades de pessoas, mas doutrina e jurisprudência caminharam para seu reconhecimento também nas sociedades de capital. Uma segunda corrente, capitaneada por Marcus Lutter, viu no $\$ 705$ do BGB o fundamento específico de direito societário para o dever de lealdade; ${ }^{69}$ esse artigo - de teor semelhante ao art. 981do CC - prevê que, pelo contrato de sociedade, os sócios se obrigam reciprocamente a contribuir para a obtenção do fim comum. A crítica que se faz a este posicionamento é a de que o fundamento soa artificial para sociedades de capital. É certo que, ao adquirir ações, um acionista adere ao estatuto, ou, como prefere Lutter, adquire o status socii e passa a exercer todos os direitos e deveres inerentes a essa condição. ${ }^{70}$ Contudo, o âmbito de aplicação original do artigo é o das sociedades de pessoas, e abrange apenas o dever de contribuir para a persecução do fim social comum, sem referência a um dever de respeito aos interesses dos demais sócios. ${ }^{71}$

São defendidas, por conta disso, três outras teorias que prescindem de um fundamento estritamente societário para a sua aplicação e que, por conta disso, são de especial interesse para o eventual reconhecimento de deveres de lealdade entre credores. O primeiro desses posicionamentos é o que considera o dever de lealdade uma decorrência do dever geral de

68 "Tradicionalmente, o dever de lealdade foi relacionado à estrutura personalista da sociedade". KARSTEN SCHMIDT, Gesellschaftsrecht, $4^{\text {a }}$ ed. atual., Köln/Berlin/Bonn/München, Carl Heymann, 2002, §20 IV 2, p. 589 (No original: "Herkömmlicherweise wurde die Treupflicht mit der personalistischen Struktur der Gesellschaft in Verbindung gebracht").

69 MARCUS LUTTER, "Theorie der Mitgliedschaft - Prolegomena zu einem Allgemeinen Teil des Korporationsrechts", cit., p. 104.

70 MARCUS LUTTER, "Theorie der Mitgliedschaft - Prolegomena zu einem Allgemeinen Teil des Korporationsrechts", cit., p. 98.

71 JOACHIM HENNRICHS, "Treupflichten im Aktienrecht - zugleich Überlegungen zur Konkretisierung der Generalklausel des $§ 242$ BGB sowie zur Eigenhaftung des Stimmrechtvertreters”, in AcP, vol. 195, 1995, pp. 221-273, p. 229. 
boa-fé. $^{72}$ No segundo, defende-se que o dever de lealdade seria uma cláusula geral de origem jurisprudencial, fundada na necessidade prática de vedar comportamentos irregulares, que pode ser extraída por meio da análise teleológica de normas diversas. ${ }^{73}$ Por fim, considera-se que o dever de lealdade seria consequência da necessária correlação entre o poder de impor a própria vontade a demais membros da coletividade e a responsabilidade daí decorrente. ${ }^{74}$

Há ainda dissenso na doutrina alemã acerca do fundamento do dever de lealdade, mas, analisada em perspectiva histórica, percebem-se uma progressiva diminuição da relevância da manifestação de vontade por meio da qual a coletividade é criada e um alargamento do alcance do dever de lealdade para todas aquelas situações em que é dado a um sujeito influenciar nas esferas jurídicas alheias no processo de formação da vontade coletiva; prerrogativa em que, necessariamente, o sujeito deve estar limitado por respectivos deveres de consideração à coletividade e aos seus integrantes.

\subsubsection{CONTEÚDO DO DEVER DE LEALDADE SOCIETÁRIO}

A determinação do alcance e do conteúdo do dever de lealdade não é dada a priori. Ela depende da análise do regramento jurídico positivo, da estrutura real da coletividade, da possibilidade de influência outorgada aos participantes, dentre outros fatores. Como afirma Menezes Cordeiro, é necessário "depurar o tema da lealdade: ele vai sobrepor-se com regimes técnicos-jurídicos mais precisos [...] quando isso aconteça, o dever de lealdade, como figura mais geral e, nessa medida, residencial, deve ceder em face das realidades dogmáticas mais estritas". 75 Ademais, o dever de lealdade, como o dever de boa-fé, não é regra passível de subsunção. ${ }^{76}$

\footnotetext{
72 JOACHIM HENNRICHS, "Treupflichten im Aktienrecht - zugleich Überlegungen zur Konkretisierung der Generalklausel des $§ 242$ BGB sowie zur Eigenhaftung des Stimmrechtvertreters”, cit., pp. 228-235.

73 Uwe HüfFer, Aktiengesetz, 5. ed., München, C.H. Beck, 2002, §53a, Rn.15, p. 253; ANTÓNIO MENEZES CORDEIRO, “A Lealdade no Direito das Sociedades”, cit., p. 1057.

74 Nesse sentido, HERBERT WIEDEMANN, Gesellschaftsrecht I - Grundlagen, cit., §8 II 3, p. 432; BGH, II ZR 205/94, j. 20.03.1995, publicado em NJW 1995, 1739 (“Girmes).

75 ANTÓNIO MENEZES CoRdEIRO, “A Lealdade no Direito das Sociedades”, cit., p. 1054.

76 JOACHIM HENNRICHS, "Treupflichten im Aktienrecht - zugleich Überlegungen zur Konkretisierung der Generalklausel des §242 BGB sowie zur Eigenhaftung des Stimmrechtvertreters”, cit., p. 244; ANTÓNIO MENEZES CordeIRo, “A Lealdade no Direito das Sociedades”, cit., p. 1054.
} 
No direito societário, seus principais desdobramentos são: ${ }^{77}$ (i) o dever de promover e de concretizar o fim comum e a proibição de adoção de comportamentos prejudiciais à sociedade; e (ii) o dever de consideração aos interesses dos demais sócios derivados de sua condição de sócios ou a ela relacionados.

Adentram no âmbito de incidência do dever de lealdade outras figuras costumeiramente tratadas de forma independente. Assim, a proibição de atuação em conflito de interesses e da prática de atos emulativos são abrangidas pelo dever de lealdade. ${ }^{78}$

\subsubsection{APLICAÇÃ̃o A COLETIVIDADES OBRIGATÓRIAS}

É discutida na doutrina alemã a possibilidade de reconhecer a existência de deveres de lealdade também em coletividades obrigatórias (Zwanggemeinschaften), que não derivam de um ato voluntário de associação. Para parte da doutrina, de que Marcus Lutter é o principal representante, coletividades obrigatórias seriam incompatíveis com a existência de deveres de lealdade: as associações obrigatórias, como o espólio, ou as comunhões de interesse, representariam a negação da autonomia privada. ${ }^{79}$ Nas coletividades obrigatórias, não se poderia, portanto, impor aos participantes o dever de perseguir a finalidade comum da coletividade, nem o de lealdade em relação à coletividade e a seus integrantes. ${ }^{80}$

Esse posicionamento é coerente com a tese de Lutter, que identifica o fundamento do dever de lealdade no negócio jurídico societário. Mas, para aqueles que consideram o dever de lealdade como necessário contrapeso ao poder concedido a um integrante da coletividade de impor sua vontade aos demais, os integrantes estariam sujeitos a deveres de lealdade também na comunhão de interesses. Nesse sentido é o posicionamento de Herbert Wiedemann. Para o autor, em todas coletividades, e mesmo nas comunhões de interesse, vigem normas comportamentais básicas, como o dever de tratamento igualitário dos

77 MARCUS LUTTER, "Treupflichten und ihre Anwendungsprobleme”, in ZHR, vol. 162, 1998, 164185, p. 167-168.

78 MARCElo V. VON ADAMEK, Abuso de Minoria em Direito Societário (Abuso das Posições Subjetivas Minoritárias), cit., pp. 150-151.

79 MARCUS LUTTER, "Theorie der Mitgliedschaft - Prolegomena zu einem Allgemeinen Teil des Korporationsrechts", cit., p. 145.

$80 \quad$ Id., p. 145. 
integrantes e o dever de consideração em relação aos interesses legítimos da coletividade. ${ }^{81}$ No mesmo sentido, Karsten Schmidt, em um escrito recente, considerou que a separação entre associações finalísticas e associações obrigatórias proposta por Lutter há três décadas não levava em consideração a circunstância de que, a despeito de terem gênese diversa, também as associações obrigatórias carregam seu nome com razão, pois, antes de serem obrigatórias, são associações. ${ }^{82}$

No âmbito específico das comunhões de interesse, reconhece-se que, apesar da não existência de um ato voluntário que crie a comunhão, vige entre os integrantes um dever de ter em consideração os interesses dos demais integrantes, que serão afetados por sua atitude. $^{83}$

\subsubsection{DEVER DE LEALDADE ENTRE CREDORES}

A questão seguinte é a de saber se, dentre as diversas comunhões de interesse, deveres de lealdade também vigem na coletividade de credores.

A indagação foi debatida pelo Tribunal Superior Alemão (BGH) no caso que ficou conhecido como "Obstrutor de Acordo" (Akkordstörer-Urteil). ${ }^{84}$ Um grupo empresarial que atuava no ramo imobiliário aproximava-se do estado de insolvência e passou a negociar com seus quase 150 credores uma forma de repactuar suas obrigações de forma coletiva. Os bancos envolvidos concordaram com a extensão do prazo de pagamento, desde que houvesse adequada remuneração. Demonstrou-se que a renegociação seria insuficiente para a manutenção da empresa, e o grupo empresarial voltou a negociar com seus credores. Em uma nova proposta, o grupo sugeriu a redução de todos os créditos em $25 \%$, o que foi aceito por mais de três quartos dos bancos credores. Contudo, um grupo de 7 bancos dinamarqueses não concordou com nenhuma outra renegociação. Ressaltando a importância da renegociação da dívida para a manutenção de mais de 50 mil postos trabalho, o devedor defendeu que os bancos dinamarqueses estariam obrigados a renegociar sua dívida.

81 HERBERT WIEDEMANN, Gesellschaftsrecht I-Grundlagen, cit., §1 I 2, p. 14.

82 KARSTEN SCHMIDT, “Das Recht der Mitgliedschaft: Ist 'korporatives Denken’ passé?”, in ZGR, n. 2, 2011, pp. 108-135, p. 114.

83 GÜNTHER WÜST, Die Interessengemeinschaft: ein Ordnungsprinzip des Privatrechts, cit., pp. 61-63.

$84 \quad$ BGH, IX ZR 178/91, j. 12.12.1991. 
Nas instâncias de origem, acataram-se três argumentos principais do grupo devedor. O primeiro argumento foi o de que os credores, já antes do estado de insolvência, constituiriam uma comunhão de interesses (Interessengemeinschaft) $;{ }^{85}$ o segundo, de que a proteção de postos de trabalho derivaria do princípio do estado social, justificando a intervenção estatal contra a atitude egoística dos bancos privados; ${ }^{86}$ por fim, o argumento de que a negativa dos bancos credores constituiria atuação de má-fé e abuso do direito, pois obteriam um proveito particular às custas do comportamento solidário e cooperativo dos demais bancos credores. ${ }^{87}$

Todos os argumentos foram rejeitados pelo BGH. Em primeiro lugar, o BGH reconheceu que se estabelece uma comunhão de interesses entre os credores com a declaração da insolvência; entretanto, não antes disso. Considerou, portanto, que, por maior que seja a coligação entre os interesses dos credores, nada há que os vincule juridicamente. Dessa maneira, apesar de reconhecer que seria juridicamente adequada a proteção contra o comportamento oportunista de credores, o BGH entendeu que não poderia criar uma norma que não existia. ${ }^{88}$ Decidiu, ainda, que tampouco se poderia derivar um regramento próprio diretamente do princípio jurídico do estado social, que, por sua vagueza e indeterminação, não poderia ser traduzido em diretrizes concretas para a atuação de juízes. ${ }^{89}$

Essa decisão foi objeto de intensa crítica por Horst Eidenmüller. ${ }^{90}$ Quando o devedor busca renegociar as condições de débito com seus credores, instaura-se uma situação de dilema dos prisioneiros entre os credores, caracterizada pela discrepância entre a racionalidade individual e a coletiva. Há uma imanente contraposição entre o interesse coletivo dos credores em maximizar os valores disponíveis para sua satisfação e o interesse de cada credor em contribuir na menor medida possível para que esse resultado seja alcançado. ${ }^{91}$

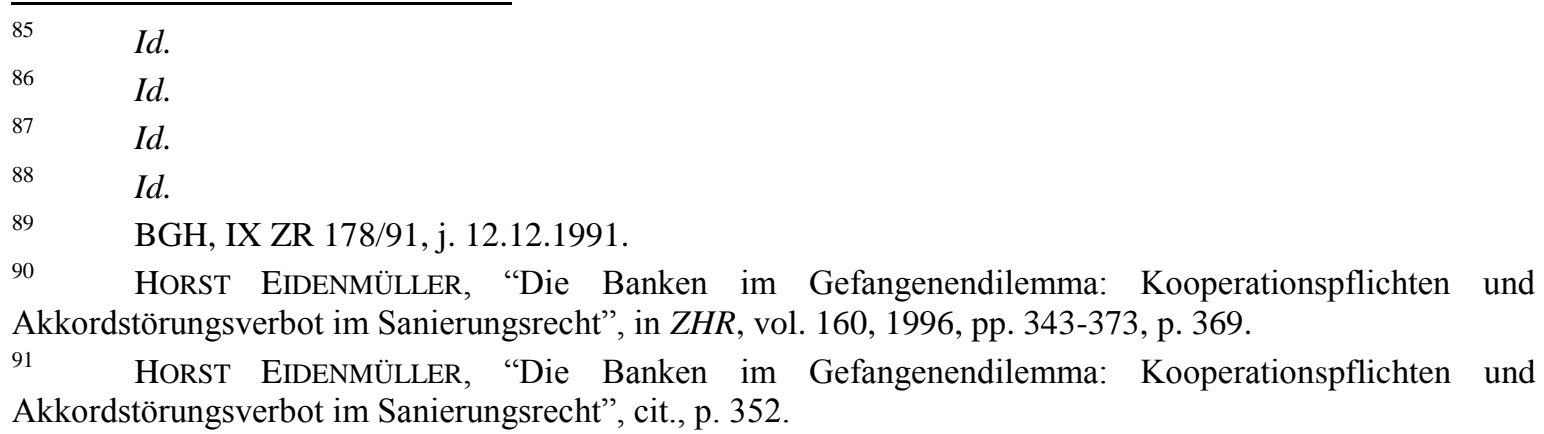


Considerando o alargamento progressivo do âmbito de atuação dos deveres de lealdade e o reconhecimento jurisprudencial de que também acionistas minoritários são destinatários de deveres de lealdade, Eidenmüller defende que, com o agravamento da situação de crise, forma-se uma comunhão de interesses entre os credores, o que impõe a eles deveres de cooperação em diversas instâncias. Entre os deveres de menor intensidade, o autor lista deveres de negociação, dentre os quais o dever de estar presente a negociações com o devedor e de apresentar, de forma honesta, seus interesses na negociação com o devedor; sob a forma mais acentuada, os deveres de cooperação adotam a forma de um dever de consentir (Zustimmungspflicht) com medidas de saneamento que não tragam prejuízo ao credor e beneficiem a comunhão. ${ }^{92}$

Com base no posicionamento de Eidenmüller, vem crescendo o reconhecimento de que os credores são destinatários de dever de lealdade. ${ }^{93} \mathrm{O}$ tema foi objeto de estudo monográfico por Dirk Schulz, que fundamenta a existência de deveres de lealdade entre os credores na circunstância de que estes têm a possisibilidade de intervir nas esferas jurídicas dos demais credores. $^{94}$

Diante da evolução do entendimento doutrinário acerca do dever de lealdade, confirma-se que a dificuldade maior não é a de determinar sua existência, mas a de identificar o alcance e a conformação concretos desses deveres.

\subsubsection{CONTEÚDO DO DEVER DE LEALDADE ENTRE OS CREDORES}

No direito concursal, Dirk Schulz considera que os credores, por participarem de uma comunhão de interesses, são proibidos de obter vantagens particulares às custas dos demais credores ${ }^{95}$ e são destinatários de deveres ativos e passivos de consideração à comunhão e aos demais credores. ${ }^{96}$

92 O autor detalha o conteúdo destes deveres de cooperação, e seu fundamento dogmático em sua extensa e profunda monografia sobre o assunto. cf. HORST EIDENMÜLLER, Unternehmenssanierung zwischen Markt und Gesetz, Köln, Otto Schmidt, 1999, pp. 583-806.

93 GEORG BITTER, "Sanierung in der Insolvenz - Der Beitrag von Treue- und Aufopferungspflichten zum Sanierungserfolg”, in ZGR, n. 2-3, 2010, pp. 147-200.

94 DIRK SCHULZ, Treuepflichten unter Insolvenzgläubigern, Köln, RWS, 2003, p. 104.

95 DIRK SCHULZ, Treuepflichten unter Insolvenzgläubigern, p. 102.

$96 \quad$ Id., p. 104. 
O que é peculiar para a aplicação do dever de lealdade entre os credores é o fato de que, nessa coletividade, não há um ato voluntário que designe qual o fim comum que os integrantes se comprometem a perseguir.

Apesar da falta de ato voluntário, a finalidade comum corresponde à finalidade a ser perseguida pelos credores, na qualidade de credores e pode ser definida como o "interesse que tem cada credor em, ao menos em médio prazo, minimizar seus prejuízos, mediante a ampliação das disponibilidades da massa". ${ }^{97}$

\subsubsection{DEVER DE LEALDADE NO DIREITO BRASILEIRO}

As afirmações precedentes, embora fundadas na experiência alemã, estão igualmente fundamentadas no direito brasileiro. Como afirma Marcelo V. Adamek, o dever de lealdade tem fundamento ético-jurídico no princípio da correlação entre poder e responsabilidade e pode ser extraído de normas societárias, mas diretamente do princípio da boa-fé objetiva, que rege não somente as relações contratuais (CC, art. 422), mas limita o exercício de todas as posições jurídicas (CC, art. 187). ${ }^{98}$

O reconhecimento da vigência do dever de lealdade entre os credores fundamenta-se na consideração de que também nessa coletividade é possível a um indivíduo confluir para a formação de vontade que vinculará a todos. Como decorrência da boa-fé, o dever de lealdade limita o exercício de posições jurídicas pelos credores, aí incluído o exercício de direito de voto em deliberações no procedimento de recuperação judicial. Impõe, com isso, deveres ativos e passivos em relação à comunhão e aos demais credores, e de respeito aos interesses dos demais credores.

Os contornos concretos desse dever de lealdade entre os credores variam em função da situação concreta, e, portanto, serão objeto de análise contextualizada no capítulo 4, infra.

97 Erasmo V. A. e N. França, in Francisco S. de Souza Junior, Antônio SÉrgio A. DE M. PIтомво (coord.), Comentários à Lei de Recuperação de Empresas e Falência, cit., p. 192.

98 Marcelo V. VON ADAMEK, Abuso de Minoria em Direito Societário (Abuso das Posições Subjetivas Minoritárias), cit., p. 137. 


\section{DOGMÁTICOS}

Ao exercer um direito, seu titular comete ato ilícito caso exceda "manifestamente os limites impostos pelo seu fim econômico ou social, pela boa-fé ou pelos bons costumes" (CC, art. 187). O presente capítulo visa a analisar os fundamentos dogmáticos para a ocorrência do abuso do direito de voto em deliberação acerca do plano de recuperação judicial.

\subsection{ABUSO DO DIREITO}

Para determinar os pressupostos e as consequências do abuso do direito ${ }^{99}$ de voto pelo credor, é necessário traçar breve historiografia da evolução do instituto do abuso do direito nos ordenamentos francês, em que surgiu, e no alemão, onde tomou feição diversa. Passo subsequente, cabe analisar o histórico do abuso do direito no Brasil. Por fim, insta analisar se o direito de voto pode ser exercido abusivamente pelo credor, quais os requisitos para tanto e quais as consequências que daí decorrem.

\subsubsection{EVOLUÇÃo HISTÓRICA}

A repressão ao exercício irregular do direito remonta ao direito romano, em que se conheciam as figuras da aemulatio e da exceptio doli generalis. Entretanto, há divergência sobre o alcance desses institutos. Para Mario Rotondi, não se pode considerar que o direito romano clássico tenha conhecido na aemulatio um instrumental de aplicação geral contra o ato abusivo; pelo contrário, a ductilidade do jus pretorium foi o instrumento por meio do qual os antigos institutos foram ajustados às alterações no ambiente socioeconômico; a

\footnotetext{
99 Prefere-se aqui a expressão "abuso do direito" à expressão "abuso de direito", pois, como anota PONTES DE MiRANDA, “[a] expressão 'abuso de direito' é incorreta. Existe 'estado de fato' e 'estado de direito'; porém não 'abuso de fato', ou 'abuso de direito'. Abusa-se de algum direito, do direito que se tem.” (F.C. Pontes De Miranda, Tratado de Direito Privado, Tomo 53, $2^{\text {a }}$ ed., Rio de Janeiro, Borsoi, 1966, $\$ 5.500$, p. 71). O autor sublinha, ademais, que a expressão é a utilizada nos países de língua latina ( $a b u s d u$ droit, na França; abuso del derecho, na Espanha; abuso di diritto, na Itália). Acrescente-se às considerações de PonTES DE MIRANDA que a expressão foi também utilizada pelo Código Civil Português na epígrafe do art. 334. Não nos parece, contudo, que a expressão "abuso de direito" seja errada; apenas que a expressão "abuso do direito" melhor retrate o fenômeno.
} 
aemulatio teve aplicações diversas, e sua proibição não poderia ser considerada como princípio de aplicação geral. ${ }^{100}$ Por outro lado, há quem divise na exceptio doli generalis o fundamento para negar a repetida acusação de que o direito romano seria extremamente egoísta; o dever de bona fides, que está na base da exceptio, exigiria justamente a consideração para com os interesses da contraparte. ${ }^{101}$ De toda forma, Menezes Cordeiro considera que o abuso do direito não teve consagração geral no direito romano, ainda que os insitutos mencionados tenham exercido funções que hoje seriam adstritas ao abuso do direito. ${ }^{102}$

A moderna compreensão do abuso do direito origina-se na jurisprudência francesa de meados do século XIX. ${ }^{103} \mathrm{O}$ Código Napoleônico foi inspirado pelo ideário liberal, insculpido na Declaração Universal dos Direitos do Homem e do Cidadão, de 1789, que, em seu art. $4^{\circ}$, determinava que "[a] liberdade consiste em poder fazer tudo que não prejudique o próximo: assim, o exercício dos direitos naturais de cada homem não tem por limites senão aqueles que asseguram aos outros membros da sociedade o gozo dos mesmos direitos." 104 Em consonância com essa ideologia, o direito de propriedade viria a ser definido no célebre art. 544 do Code Civil como o direito de fruir e de dispor das coisas "da maneira mais absoluta, desde que o uso não seja proibido por lei ou regulamento". ${ }^{105}$ Em ruptura com a tradição do ius commune, o direito francês afastou a figura da aemulatio e da exceptio doli, e não previu, em seu lugar, institutos que lhes fizessem as vezes. ${ }^{106}$

100 MARio Rotond, L'Abuso di Diritto. Aemulatio”, Padova, CEDAM, 1979, p. 92 (note-se, contudo, que o livro corresponde a uma reeimpressão da tese de doutorado de RoTONDI, antes publicada na Rivista di Diritto Civile, 1923, pp. 105-128; pp. 208-352; pp. 416-457).

101 OTTO WENDT, "Die exceptio doli generalis in heutigem Recht oder Treu und Glauben im Recht der Schuldverhältnisse", in $A c P, 1906$, pp. 1-417, p. 4.

102 António Menezes Cordeiro, Da Boa Fé no Direito Civil, cit., pp. 676-677.

103 FILIPPO RANIERI, “Abuse of Law”, in JÜRGEN BASEDOw, KLAUS J. HOPT, REINHARD ZIMMERMANN, ANDREAS STIER (coord.), The Max Planck Encyclopedia of European Private Law, vol. 1, Oxford, Oxford University Press, 2012, pp. 5-7, p. 5.

104 Art. 4: La liberté consiste à pouvoir faire tout ce qui ne nuit pas à autrui: ainsi, l'exercice des droits naturels de chaque homme n'a de bornes que celles qui assurent aux autres Membres de la Société la jouissance de ces mêmes droits. Ces bornes ne peuvent être déterminées que par la Loi.

$105 \quad$ Code Civil, art., 544: "La propriété est le droit de jouir et disposer des choses de la manière la plus absolue, pourvu qu'on n'en fasse pas un usage prohibé par les lois ou par les règlements."

106 António Menezes CORdeiro, Da Boa Fé no Direito Civil, cit., p. 679. 
O "absolutismo"107 de direitos subjetivos do Código Napoleônico plantava a semente para que situações flagrantemente incompatíveis com o sentimento ético reclamassem intervenção judicial. ${ }^{108}$ Em 1855, a Corte de Apelação de Colmar viu-se diante do hoje célebre caso em que um proprietário erigiu uma chaminé falsa em seu terreno com o escopo único de retirar de seu vizinho a vista de que desfrutava. ${ }^{109}$ Ao julgar a ação, o Tribunal entendeu que "se é um princípio que o direito de propriedade é de toda forma absoluto, autorizando o proprietário a usar e abusar da coisa, então, o exercício desse direito, como o de todos, deve ter por limite a satisfação de um interesse sério e legítimo; [...] os princípios da moral e da equidade impedem que a justiça sustente uma ação inspirada pela maldade, executada sob o signo de uma má paixão e que não se justifica por nenhuma utilidade pessoal e acarreta um grave prejuízo a outrem". 110

A jurisprudência francesa passou a aplicar a figura do abuso do direito a uma série de situações em que o titular agia com o escopo único de prejudicar um terceiro, sem perseguir com isso um interesse legítimo. Entretanto, a jurisprudência não tomava o abuso do direito como figura de aplicação geral, e, sobretudo, não o aplicava como fundamento para a anulação de atos praticados de forma abusiva. ${ }^{11}$

Louis Josserand, em obra clássica sobre o tema, após analisar a jurisprudência francesa e àquela altura já farta doutrina, buscou ampliar o escopo do abuso do direito para além da problemática da responsabilidade civil. Para o autor, todo direito subjetivo seria concedido ao particular para que perseguisse um motivo legítimo. $\mathrm{O}$ abuso do direito, nesse sentido, seria uma figura de aplicação geral ao exercício de todos os direitos e estaria configurado

\footnotetext{
107 A expressão é de F.C. Pontes DE MiRanda (Tratado de Direito Privado, Tomo 53, cit., §5.500, p. 63).

108 SAlVATORE PATTI, "Abuso del diritto (voce)", in Digesto delle discipline privatistiche (sezione civile), Torino, UTET, 1987, p. 2.

109 HANS MERZ, "Vom Schikaneverbot zum Rechtsmissbrauch", in Zeitschrift für Rechtsvergleichung, vol. 18, 1977, pp. 162-171, p. 164.

$110 \quad$ "S'il est de principe que le droit de propriété est en quelque sorte absolu, autorisant le propriétaire à user et abuser de la chose, cependant l'exercise de ce droit, comme celui de tout autre, doit avoir pour limite la satisfaction d'un intérêt serieux et legitime; ... les principes de la morale et de l'équité s'opposent à ce que la justice sanctionne une action inspirée par la malveillance, accomplie sous l'empire d'une mauvaise passion, ne se justifiant par aucune utilité personnelle et portant un grave préjudice à autrui" (trecho da decisão transcrito por HANS MERZ, "Vom Schikaneverbot zum Rechtsmissbrauch”, cit., p. 164).

111 HANS MERZ, "Vom Schikaneverbot zum Rechtsmissbrauch", cit., p. 165.
} 
quando o direito fosse exercido sem interesse legítimo, em desvio do fim para o qual foi instituído. $^{112}$

Essa ampliação do abuso do direito não se impôs jurisprudencialmente. ${ }^{113}$ Muito embora a doutrina do abuso do direito tenha sido estendida para abarcar o exercício de posições contratuais, e mesmo a liberdade de contratar, ${ }^{114}$ as cortes francesas permaneceram tratando o abuso do direito como mera fonte do dever de indenizar, entendido como capítulo da responsabilidade civil. ${ }^{115} \mathrm{Na}$ concepção original do abuso do direito no solo francês, não há relação com a boa-fé, ${ }^{116}$ e esta não é utilizada como forma de limitação do exercício de posições jurídicas. ${ }^{117}$

A doutrina do abuso do direito francesa foi objeto de estudo pela doutrina alemã, em um dos poucos casos de recepção da doutrina francesa em solos germânicos. ${ }^{118}$ Todavia, transposto para o direito alemão, o abuso do direito ganharia contornos bastante distintos da figura original, a ponto de Filippo Ranieri afirmar que "as hipóteses em que a jurisprudência alemã aplica a teoria do Rechtsmißbrauch não tem nada em comum com a casuística desenvolvida pelos juízes franceses em matéria de abus de droit". ${ }^{119}$

O BGB, diferentemente do Code Civil, impôs limites expressos ao exercício de direitos. Proibiu os atos emulativos, definidos como os "atos que tenham por único objetivo impor danos a outrem” (BGB, §226), e considerou ilícito civil o ato de causar danos a outrem de

\footnotetext{
112 LOUIS JOSSERAND, De l'esprit des droits et de leur relativité - Théorie dite de l'Abus des Droits, $12^{\mathrm{a}}$ ed. rev., Paris, Dalloz, 1939, pp. 311-312.

113 HANS MERZ, "Vom Schikaneverbot zum Rechtsmissbrauch”, cit., p. 165.

114 SimON WhitTAKER, REINHARD ZIMMERMANN, "Good Faith in European Contract Law: Surveying the Legal Landscape", in SimON WhitTAKER, REINHARD ZIMMERMANN (org.), Good Faith in European Contract Law, Cambridge, Cambridge Press, 2000, pp. 7-62, p. 35.

115 António Menezes Cordeiro, Da Boa Fé no Direito Civil, cit., p. 705.

116 António Menezes Cordeiro, Da Boa Fé no Direito Civil, cit., p. 684 ("a boa-fé não se conecta com a orientação original do abuso do direito").

117 FILIPPO RANIERI, "Bonne Foi et Exercise du Droit dans la Tradition du Civil Law", in RIDC, vol. 50, n. 4, 1998, pp. 1055-1092, pp. 1081-1089; KONRAD ZWEIGERT, HEIN KöTZ, Einführung in die Rechtsvergleichung, cit., §40 IV, pp. 623-624.

118 António Menezes CordeIro, Da Boa Fé no Direito Civil, cit., p. 685. Apesar de diversos estudos comparatísticos terem sido escritos na Alemanha no começo do século XX, o mais influente foi o de Wolfgang Siebert, largamente inspirado pela doutrina de Josserand, que via os direitos sujeitos a limites internos funcionais (HANS-PETER HAFERKAMP, Die heutige Rechtsmißbrauchslehre - Ergebnis nationalsozialistischen Rechtsdenkens?, Berlin, Arno Spitz, 1995, pp. 213-224).

119 FILIPPO RANIERI, "Bonne Foi et Exercise du Droit dans la Tradition du Civil Law", cit., p. 1082: "En verité, les hypothèses où la jurisprudence allemande applique la théorie du Rechtsmißßrauch n'ont rien à voir avec la casuistique que les juges français ont développée en matière d'abus du droit”.
} 
forma incompatível com os bons costumes (BGB, §826). Mas ambos os dispositivos revelaram-se insuficientes. Ao exigir que o propósito único da atuação fosse o de impor danos a outrem, os artigos estavam praticamente predestinados a não terem aplicação prática, pois sempre haverá alguma utilidade, ainda que reduzida e desproporcional, ao titular que se vale de seu direito para impor danos a outrem. ${ }^{120}$

Em vista dessas limitações, a doutrina e a jurisprudência passaram a lançar mão da boa-fé como instrumento para a repressão do exercício abusivo de direitos. ${ }^{121}$ Enquanto a jurisprudência francesa tratava o abuso do direito como forma de ilícito civil, que pressupunha comportamento culposo e gerava a obrigação de indenizar, ${ }^{122}$ o pensamento alemão vê o princípio da boa-fé como limitador do exercício de todas as posições jurídicas, podendo o seu desrespeito gerar o dever de indenizar, mas, também, quando se refira ao exercício de posições jurídicas, gerar a ineficácia do ato, ou sua invalidade, sem que seja necessário inquirir a culpabilidade do agente.

Além disso, enquanto a discussão francesa a respeito do abuso do direito foi pautada por um pensamento dedutivo, que buscava determinar a essência do abuso do direito, para dele destrinchar situações concretas, a experiência alemã deriva de uma lenta "sedimentação jurisprudencial"123 e também doutrinária em torno de grupos de casos concretos, depois considerados, conjuntamente, hipóteses de exercício abusivo de direito. Enquanto na França o abuso do direito foi tomado como ponto de partida, na Alemanha, partiu-se da cláusula geral de boa-fé, e o abuso do direito foi tomado como referencial de sistematização para situações díspares de exercício inadmissível de posições jurídicas.

Isso não significa que, materialmente, as soluções encontradas por ambos os sistemas sejam completamente diversas. Mas, enquanto a jurisprudência alemã trata questões como, por exemplo, a decadência de direito material (Verwirkung ou Supressio) sob a rubrica do abuso do direito, como desdobramento do dever de boa-fé que limita o exercício de posições jurídicas, a jurisprudência francesa chega aos mesmos resultados, mas faz uso da

\footnotetext{
120 António Menezes Cordeiro, Da Boa Fé no Direito Civil, cit., pp. 689-690.

121 FILIPPO RANIERI, "Norma scritta e prassi giudiziali nell'evoluzione della dottrina tedesca del Rechtsmißbrauch", in RTDPC, 1972, pp. 1216-1237, p. 1231.

122 O abus du droit é considerado uma hipótese de faute, conceito que congrega de forma indistinta tanto a ideia de ilicitude quanto de culpabilidade. KONRAD ZWEIGERT, HEIN KÖTZ, Einführung in die Rechtsvergleichung, cit., §40 IV, p. 623.
}

123 António Menezes CordeIRo, Da Boa Fé no Direito Civil, cit., p. 694. 
figura da renúncia tácita. ${ }^{124}$ Os resultados são funcionalmente semelhantes, mas, no espaço jurídico francês, a boa-fé assume papel de menor centralidade.

Na Itália, em um primeiro momento, a teoria francesa foi objeto de estudos monográficos, marcados por uma geral rejeição à admissibilidade do instituto, entendido como contraditório por seus próprios termos. ${ }^{125}$ Entretanto, durante os trabalhos preparatórios da codificação de 1942, o Progetto Preliminare chegou a prever, em seu art. 7, que "ninguém pode exercer um direito em contraste com o escopo para o qual este direito foi reconhecido". ${ }^{126}$ A regra não foi codificada por conta do temor em estender por demais os poderes dos magistrados, e o legislador limitou-se à proibição da prática de atos emulativos no exercício do direito de propriedade (e não de demais posições jurídicas) definido no art. 833 do CCIt como o ato exercido com a finalidade única de causar danos a outrem. Mais uma vez, a regra seria carente de relevância, pela quase impossível conjugação de dolo específico e completa ausência de utilidade no exercício do direito.

A partir da década de 1950, a doutrina italiana afastou-se da tradição francesa, e aproximou-se dos resultados obtidos na Alemanha. Passou-se a defender que o exercício de direitos é limitado pela cláusula geral de boa-fé, interpretando de forma extensiva a regra prevista no art. 1375 do CCIt, que determina que os contratos devem ser cumpridos de boa-fé, para daí extrair a aplicabilidade geral da boa-fé em seu desdobramento de limitação no exercício de posições jurídicas subjetivas. ${ }^{127}$ Esse posicionamento foi recentemente consagrado pela Corte di Cassazione em um caso de denúncia imotivada de

124 FILIPPO RANIERI, "Bonne Foi et Exercise du Droit dans la Tradition du Civil Law”, cit., pp. 10811089.

125 FILIPPO RANIERI, "Bonne Foi et Exercise du Droit dans la Tradition du Civil Law", cit., p. 1078. MARIO Rotond foi um notório crítico do abuso do direito (L`Abuso di Diritto. Aemulatio”, cit., p. 184), filiando-se à crítica de Planiol, que considerava o abuso uma "logomaquia", expressão contraditória por seus próprios termos, pois, se há direito, não pode haver abuso. Considerava, por isso, que o abuso do direito seria um fenômeno meramente social, não um conceito jurídico (Id., p. 24).

126 "Art. 7: Nessuno può esercitare il proprio diritto in contrasto con lo scopo per cui il diritto medesimo gli è stato riconosciuto" (transcrito por SALVATORE PATTI, “Abuso del diritto (voce)", cit., pp. 4).

127 Nesse sentido, UGO NATOLI, "Note preliminari ad una teoria dell'abuso del diritto nell'ordinamento giuridico italiano", in RTDPC, 1958, pp. 18-37, p. 30 ("non basterà la astratta conformità del comportamento del soggeto al contenuto del suo diritto a farne, senz'altro, ritenere la legittimità, potendosi sempre giungere ad una conclusione diversa valutando in concreto la situazione secondo le regole della buona fede"); GIOVANNi CATtANEO, "Buona fede obbietiva e abuso del diritto", in RTDPC, 1971, pp. 613-659; PIETRO RESCIGNO, L'abuso del diritto, Bologna, Mulino, 1998, p. 277; FrANCESCO SCAGLIONE, "L'abuso del diritto nel contratto", in Dir. Proc., vol. 8, 2012, pp. 237-262, p. 246; Contra, SALVATORE PATTI, "Abuso del diritto (voce)", p. 4 (considera que não se poderia reconstruir o abuso do direito na Itália em torno da clásula geral de boa-fé por conta de critérios históricos e pela multiplicidade de formas específicas de limitação do exercício de direito no ordenamento italiano). 
contrato de distribuição. Após reconhecer que o Codice Civile não veda expressamente o abuso do direito e que a doutrina da década de 1930 era pautada por um contexto cultural de preocupação extrema com a certeza, afirma a Corte que agora os princípios da boa-fé objetiva e do abuso do direito devem ser revisitados, pois a boa-fé passou a constituir um canône geral para a avaliação da conduta das partes, limitando o exercício de direito que seja com ela incompatível ou que seja contrário ao fim social para o qual foi instituído. ${ }^{128}$

Em suma, pode-se afirmar que o abuso do direito surge como construção jurisprudencial francesa para fazer as vezes da ausente proibição da prática de atos emulativos. Sua aplicação, na França, avança pouco para além desses limites e permanece como instrumento para a imposição de responsabilidade civil, atrelada à análise da culpa. Já a doutrina do abuso do direito, na Alemanha e, depois, na Itália, teria configuração distinta, apresentando-se como desdobramento da boa-fé. Atua, dessa forma, não apenas como fonte de responsabilidade, mas também como limitação ao exercício de posições jurídicas.

\subsubsection{O ABUSO DO DIREITO NO BRASIL: UM INSTITUTO ENTRE DUAS TRADIÇÕES}

No Brasil, o Código Civil de 1916 não previa expressamente o abuso do direito. O art. 160, I do CC/1916, porém, determinava que não constituem ilícitos os atos praticados em "exercício regular de um direito reconhecido". Interpretando o artigo a contrario sensu, Clóvis Bevilaqua, seu autor, entendia positivada a doutrina francesa da proibição do abuso do direito. ${ }^{129}$ Era, como indicou Pontes de Miranda, uma fórmula "um tanto misteriosa", 130 pois, certamente, a ligação entre o preceito normativo e a doutrina francesa era tênue.

O abuso do direito foi objeto de estudos doutrinários ${ }^{131}$ e de decisões jurisprudenciais, a princípio esparsas, e, depois, mais profusas, em diversos ramos do direito. ${ }^{132}$ Entretanto,

\footnotetext{
128 Cass. 18.09.2009, n. 20106.

129 Clóvis Bevilaqua, Código Civil dos Estados Unidos do Brasil, vol. 1, $3^{\text {a }}$ ed., São Paulo/Rio de Janeiro, Francisco Alves, 1927, p. 422: "Estatue o art. 160, I, que não constittue acto illícito o praticado no exercício regular de um direito reconhecido. A contrario sensu, o praticado em exercício não regular de um direito, e illícito. Eis ahi a condemnação do abuso do direito [...]”.

130 F.C. Pontes DE MiRAnda, Tratado de Direito Privado, Tomo 53, cit., p. 73.

131 Dentre os quais sobressai Pedro BAPTISTA MARtins, O Abuso do Direito e o Ato Ilícito, $2^{\mathrm{a}}$ ed., 1941, São Paulo/Rio de Janeiro, Freitas Bastos, 1941.

132 Judith Martins-CostA, "Os Avatares do Abuso do Direito e o Rumo Indicado pela Boa-Fé", in Mário L. Delgado, Jones F. Alves, Novo Código Civil - Questões Controvertidas, vol. 6, São Paulo, Método, 2007, pp. 505-544, pp. 510-516
} 
como sublinha Judith Martins-Costa, o abuso do direito, às vésperas do Código Civil de 2002, era uma "figura tímida", entendido como uma das subespécies de hipóteses de responsabilidade civil aquiliana previstas no art. 159 do Código Civil/1916. ${ }^{133}$ Certamente, essa situação não se devia apenas ao Código Civil de 1916. O direito brasileiro já comportava soluções diversas, baseadas no princípio da boa-fé que, nas últimas décadas de vigência do antigo Código, ganhara grande projeção. Estava correto Antunes Varela quando afirmou, em 1982, que o ordenamento jurídico brasileiro, por meio de regramentos esparsos e, sobretudo, do princípio implícito da boa-fé, poderia oferecer respostas semelhantes àquelas obtidas em outros ordenamentos. ${ }^{134}$ Todavia, apesar das possibilidades, doutrina e jurisprudência mantiveram-se ligadas à tradição francesa do abuso do direito como fonte de responsabilidade civil.

Com o Código Civil de 2002, a figura do abuso do direito foi, de forma mais evidente, positivada. ${ }^{135} \mathrm{O}$ artigo 187, inserido no Título denominado "Dos Atos Ilícitos", determina

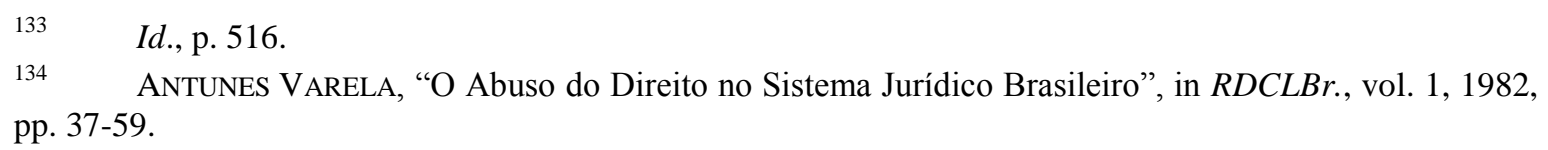

135 Respeitosamente discorda-se, neste particular, do posicionamento de José DE O. AsCENSÃo (“A Desconstrução do Abuso de Direito", in MÁrio L. Delgado, Jones F. Alves, Novo Código Civil - Questões Controvertidas, vol. 4, São Paulo, Método, 2005, pp. 33-54). Para o autor, o art. 187 do CC não teria positivado o abuso do direito, e o que estaria ali retratado não seria mais do que a justaposição de três situações distintas (contrariedade à função social, aos bons costumes e à boa-fé), que não seriam passíveis de recondução a um denominador comum; ademais, afirma que não está regrada no art. 187 a situação prototípica do abuso do direito, qual seja, a vedação da prática de atos emulativos (que, critica o autor, surge estranhamente no âmbito do direito de propriedade, no art. 1228, $\$ 2^{\circ}$ do CC). Entretanto, essas razões não parecem suficientes para negar a qualificação dogmática da figura regrada no art. 187 como abuso do direito. $\mathrm{O}$ abuso do direito francês, de fato, foi erigido tendo em vista o combate à prática de atos emulativos. Mas, no direito alemão, que deu origem mediata ao art. 187, o abuso do direito é figura doutrinária autônoma da proibição de atos emulativos (prevista no $\$ 226 \mathrm{BGB}$ ) e, mais do que isso, lhe abarca, pois a prática de um ato que não traga benefícios ao titular e apenas prejudique ao terceiro seria também, mesmo que não houvesse a proibição de atos emulativos, vedada pela boa-fé. Diante disso, o fato de que a proibição à prática de atos emulativos esteja na parte geral (como na Alemanha), ou na parte especial relativa aos direitos de propriedade (como na Itália - CCIt, art. 833 - e no Brasil - CC, art. 1288, §2 $2^{\circ}$, ou mesmo que não fosse regrada, não retira a autonomia dogmática do abuso do direito. Já a referência a mais de um vetor para a determinação do abuso não afasta a possibilidade de se reconhecer que há nele um núcleo comum. O artigo 187 veda comportamentos tipicamente enquadrados sob a rubrica do abuso do direito na Alemanha, na Itália, e também em Portugal (que, em seu Código Civil, no artigo 334, traz dispositivo de teor praticamente idêntido ao artigo 187 do CC/2012, cuja epígrafe é "abuso do direito"), e que são caracterizados pela circunstância de que, apesar de aparentemente representarem um exercício do direito, significam, em concreto, uma subversão de sua finalidade. É, então, sob a perspectiva histórica (por que a doutrina e jurisprudência de diversos países recorreram à figura do abuso do direito, se já contavam com a categoria do ilícito?) que se pode compreender a unidade e a continuidade do abuso do direito enquanto modelo dogmático, ora adotado pelo Código Civil de 2002 (PIETRO RESCIGNO, "L`abuso del diritto", in Riv. Civ., 1965, Parte I, pp. 203-290, p. 218: "La diversità degli strumenti positivi adoperati non toglie unità al problema dell'abuso, se si guarda il problema nei termini che si è cercato di chiarire, e cioè como 'questione' sorta storicamente dallo sviluppo e dalle contraddizioni della società liberale e dell'economia capitalistica, e mantenuta aperta dalla crisi sempre più acuta della società liberale e del suo sistema economico"). 
que: [t]ambém comete ato ilícito o titular de um direito que, ao exercê-lo, excede manifestamente os limites impostos pelo seu fim econômico ou social, pela boa-fé ou pelos bons costumes".

O artigo é quase cópia do artigo 334 do Código Civil português, que é, por sua vez, praticamente tradução do art. 281 do Código Civil grego, o qual, por seu turno, foi inspirado pela doutrina alemã posterior à vigência do BGB. ${ }^{136}$ Ao adotar uma redação derivada da cultura jurídica alemã, que prestigia a boa-fé como elemento delimitador do exercício regular de direitos e posições jurídicas, o direito brasileiro afasta-se da tradição francesa, e passa a ter na boa-fé o eixo ordenador do exercício regular de direitos. ${ }^{137}$

Natural, portanto, que a nova configuração do abuso do direito tenha levantado diversas polêmicas, que serão analisadas no presente trabalho na medida necessária para a determinação dos pressupostos aptos a considerar como abusivo o exercício do direito de voto por um credor e, também, para a determinação das consequências que podem daí advir.

\subsubsection{CONTORNOS DOGMÁticos E APLICAÇÃO AO EXERCícIO DO DIREITO DE VOTO}

Desconsiderando questões teóricas gerais relacionadas ao abuso do direito e que não podem ser aqui abordadas, cabe analisar (i) se é possível que o exercício de direito de voto pelo credor seja abusivo; (ii) em que hipóteses isso poderá ocorrer; (iii) se é necessário que o credor, para tanto, atue com dolo ou culpa; (iv) quais as consequências daí decorrentes, (v) se pode ser conhecido de ofício pelo magistrado; e (vi) se qualquer espécie de abuso é coibida.

\footnotetext{
136 Razão pela qual JAN PETER SCHMIDT considera que o art. 187 CC possa ser tido como um produto indireto da ciência jurídica alemã (Zivilrechtskodifikation in Brasilien, Hamburg, Mohr Siebeck, 2009, p. 463).

137 Judith Martins-Costa, "Os Avatares do Abuso do Direito e o Rumo Indicado pela Boa-Fé", cit., p. 528: "[a] fórmula do art. 187 significa, do ponto de vista cultural, uma verdadeira ruptura que apenas se concretizará, no entanto, se trabalhada, devidamente, a sua pré-compreensão. A ruptura de que se fala é relativa à tradição do abuso até então seguida em nossa doutrina, pois da concepção 'francesa' que marcara a atribulada recepção no Brasil - delineando a forma de compreensão do art. 166, I do Código de 1916 - o vigente Código passou a uma concepção 'germânica' em tudo estranha àquela".
} 


\subsubsection{ABUSO NO EXERCÍCIO DO DIREITO DE VOTO}

O abuso do direito não diz respeito somente ao exercício de direito de propriedade ou ao exercício de posições contratuais. Situado na parte geral do Código Civil, o art. 187 é aplicável ao exercício de todas as posições jurídicas subjetivas ${ }^{138}$ e também ao exercício do direito de voto em qualquer deliberação. ${ }^{139}$

Por conta disso, não é preciso recorrer a uma aplicação analógica das regras de direito societário, como, por exemplo, da previsão contida no art. 115 da LSA, para reconhecer que pode haver abuso do direito de voto na assembleia geral de credores. Não há lacuna que justifique a analogia, pois o artigo 187 do CC é diretamente aplicável.

\subsubsection{LIMITES AO DIREITO DE VOTO}

O direito de voto do credor é limitado pelos usos e costumes, pela função social e pela boafé. Entretanto, seria errôneo buscar deduzir de conceitos abertos, e em abstrato, quais os limites a que está sujeito o direito de voto. A análise dogmática do abuso do direito, bem como a aplicação de outras cláusulas gerais, exige a adoção de pensamento indutivo. Como aponta Menezes Cordeiro, "não há limites genéricos aos direitos mas, tão só, disposições limitativas. Todos os limites efectivos ao conteúdo dos direitos exigem uma determinação do caso concreto." 140

\footnotetext{
138 cf. JUdith Martins-Costa, "Os Avatares do Abuso do Direito e o Rumo Indicado pela Boa-Fé”, cit., p. 533); e ANTONIO JUNQUEIRA DE AZEVEDO, “(Parecer) Contrato de distribuição por prazo determinado com cláusula de exclusividade recíproca. Configuração de negócio jurídico per relationem na cláusula de opção de compra dos direitos do distribuidor pelo fabricante e conseqüente restrição da respectiva eficácia. Exercício abusivo do direito de compra, equivalente a resilição unilateral, sem a utilização do procedimento pactuado, com violação da boa-fé objetiva”, in Novos Estudos e Pareceres de Direito Privado, São Paulo, Saraiva, 2009 , pp. 287-310, p. 302. Essa posição prevalece também no direito alemão (KARL LARENZ, Allgemeiner Teil des Bürgerlichen Rechts, cit., \$16 III, Rn. 11, p. 282); no direito italiano (PIETRO RESCIGNO, L'abuso del diritto, pp. 274-275, e Cass. 18.09.2009, n. 20106); e no direito português (ANTÓNIO Menezes Cordeiro, Da Boa Fé no Direito Civil, cit., p. 898; Mario J. De A. Costa, Direito das Obrigações, $12^{\mathrm{a}}$ ed., Coimbra, Almedina, 2009, p. 87).

139 JUdith Martins-Costa, "Os Avatares do Abuso do Direito e o Rumo Indicado pela Boa-Fé", cit., p. 538-540. cf. também KARL LARENZ, Allgemeiner Teil des Bürgerlichen Rechts, cit., §16 III, Rn. 11, p. 282; RUDOLF MÜLLER-ERZBACH, "L'abuso di diritto secondo la dottrina giuridica teleologica", in Riv. Dir. Comm., 1950, Parte I, pp. 89-96, p. 95 (considerando a possibilidade de abuso do direito de voto em matéria societária); e JoRge MANUEl CoutinHo de ABReu, Do Abuso de Direito - Ensaio de um Critério em Direito Civil e nas Deliberações Sociais, Coimbra, Almedina, 1983, p. 138.

140 António Menezes CordeIRo, Da Boa Fé no Direito Civil, cit., p. 876.
} 
Os contornos concretos dos limites impostos ao direito de voto na deliberação dos credores sobre plano de recuperação judicial serão, portanto, analisados no contexto do regramento da recuperação judicial no item 2.2 infra, após a análise da configuração atual do procedimento deliberativo recuperacional.

\subsubsection{CONSEQUENCIAS JURÍDICAS}

Tradicionalmente, o abuso do direito foi entendido como causa de responsabilidade civil, em linha com a experiência francesa. Entretanto, o abuso do direito previsto no artigo 187 do CC comporta diferentes consequências jurídicas.

A responsabilidade civil continua sendo uma dessas consequências. Se o exercício de um direito for desmedido e desproporcional, incompatível com o dever de consideração em relação à posição jurídica alheia imposto pela boa-fé, então o ato será abusivo nos termos do art. 187 do CC. Esse exercício irregular de direito pode causar danos a outrem, gerando dever de indenizar (CC, art. 927). Assim, por exemplo, já entendeu o STJ que a suspensão do fornecimento de energia elétrica em razão de débito no valor de $\mathrm{R} \$ 0,85$ constitui exercício excessivo de direito, gerando o dever de indenizar o consumidor por danos morais que sofreu em decorrência do exercício abusivo do direito. ${ }^{141}$

Para além dessa função "clássica" do abuso do direito, que é a de fundamentar a responsabilidade civil e que já vinha sendo reconhecida pela doutrina e pela jurisprudência antes do Código Civil de 2002, a principal potencialidade do art. 187 do CC consiste na função de limitar o exercício de posições jurídicas, com base no dever de boa-fé. ${ }^{142} \mathrm{~A}$ jurisprudência alemã e a jurisprudência portuguesa desenvolveram, sob essa epígrafe, diversos grupos de casos típicos em que o exercício de uma posição jurídica se mostra inadmissível, como é o caso do venire contra factum proprium, das inalegabilidades de

\footnotetext{
141 STJ, REsp 811.690/RR, $1^{\text {a }}$ T., Rel. Min. DENISE ARRUDA, v.u., j. 18.05.2006, DJ 19.06.2006. Essa responsabilidade é reconhecida também no âmbito da denúncia de contratos de distribuição em sentido lato (Humberto Theodoro JR., Adriana M. T. DE Mello, "Apontamentos sobre a Responsabilidade Civil na Denúncia dos Contratos de Distribuição, Franquia e Concessão Comercial”, in RDM, vol. 122, 2001, pp. 737, p. 21).

142 Judith Martins-Costa, "Os Avatares do Abuso do Direito e o Rumo Indicado pela Boa-Fé”, cit., p. 533 .
} 
nulidades formais, da supressio e surrectio, do tu quoque e do desequilíbrio no exercício. $^{143}$

Nesses grupos de situações, o exercício abusivo pode, ou não, causar danos a outrem e, consequentemente, gerar o dever de indenizar. A principal consequência jurídica, contudo, é de outra natureza. Do abuso do direito podem decorrer, principalmente, a ineficácia do exercício de direitos potestativos (por exemplo, da denúncia imotivada em contrato relacional) ou a invalidade negocial. ${ }^{144}$

No âmbito do exercício do direito de voto, as decorrências típicas da constatação de abuso serão a anulabilidade do voto proferido abusivamente e a responsabilidade civil do credor pelos danos que daí se originem. Entretanto, as consequências do abuso do direito de voto em assembleia geral de credores serão analisadas em detalhe no capítulo 5, infra.

\subsubsection{NATUREZA DA RESPONSABILIDADE CIVIL}

Sob o Código Civil de 1916, debatia-se acerca do aspecto objetivo ou subjetivo do abuso do direito, em conformidade com a discussão doutrinária francesa travada entre a corrente subjetivista, capitaneada por Ripert, que exigia a intenção de causar dano para configurar o abuso, e a corrente objetivista, de que Josserand é o mais proeminente representante, que considerava o abuso como o exercício de direito objetivamente contrário a seu fim econômico-social. $^{145}$

Sob a vigência do Código Civil de 1916, Pedro Baptista Martins defendera o entendimento de que o abuso do direito representaria uma hipótese de responsabilidade objetiva, independente de culpa e decorrente do mero exercício contrário à finalidade do direito. ${ }^{146}$ Na sequência da edição do Código Civil, a discussão se reacendeu, e diversos autores, bem como juristas presentes à I Jornada de Direito Civil promovida pelo Centro de Estudos do Conselho da Justiça Federal, posicionaram-se no sentido de que o abuso do direito previsto

\footnotetext{
143 António Menezes Cordeiro, Da Boa Fé no Direito Civil, cit., p. 899.

144 Judith Martins-Costa, "Os Avatares do Abuso do Direito e o Rumo Indicado pela Boa-Fé”, cit., p. 531.

145 Sobre o debate, cf. SimON WhitTAKER, REINHARD ZIMMERMAnN, “Good Faith in European Contract Law: Surveying the Legal Landscape", cit., p. 34.

146 Baptista Martins, O Abuso do Direito e o Ato Ilícito, cit., pp. 236-247.
} 
no artigo 187 do CC seria categoria de ilícito que independe de culpa para sua concretização, caracterizando espécie de responsabilidade objetiva. ${ }^{147}$

Parece, todavia, que a discussão esteja situada em termos inadequados. Como afirmou Jan Peter Schmidt, é necessário diferenciar as consequências que advêm do abuso do direito para determinar se a sua configuração ocorre de forma objetiva ou se pressupõe a indagação acerca da culpabilidade. ${ }^{148}$

Nas hipóteses em que o abuso do direito gera dano, não é possível concordar com a doutrina segundo a qual a responsabilidade daí decorrente seria objetiva. Para esses doutrinadores, não seria necessário sindicar o objetivo de causar dano ou a culpabilidade do agente para que este seja responsável por indenizar os danos a que der causa. Contudo, se a regra geral da responsabilidade civil pressupõe a culpabilidade (CC, art. 186; "por ação ou omissão voluntária, negligência ou imprudência"), e se a responsabilidade objetiva é excepcional aos casos previstos em lei, e àqueles em que a atividade normalmente desenvolvida implicar, por sua natureza, risco para os direitos de outrem (CC, art. 927, par. ún.), não é compreensível a razão pela qual não se exigiria a culpabilidade como requisito para a responsabilidade civil no exercício abusivo do direito. Aplicar a responsabilidade objetiva a essa hipótese significaria afirmar que aquele que age com base em um direito de que é titular, mas dele abusa, responde objetivamente, ou seja, de forma mais gravosa, ao passo que aquele que causa dano a outrem pura e simplesmente, sem invocar o exercício de um direito, responderia de forma mais branda, pois só cometeria ilícito se agisse com culpa ou dolo. O resultado é contraditório e, por isso, deve ser rechaçado. Se o abuso do direito causar danos a outrem, a responsabilidade daí decorrente ao agente que causar o dano é regrada pelo regime geral da responsabilidade civil, tendo natureza de responsabilidade subjetiva. ${ }^{149}$

147 José CARlos B. Moreira, “Abuso do Direito", in RTDC, vol. 13, 2003, pp. 97-110, p. 105; DANIEL M. Boulos, Abuso do Direito no Novo Código Civil, São Paulo, Método, 2006, p. 140 ("Uma vez configurado o ato ilícito tal como definido no artigo 187 do Código [...], e desde que dele irradiem danos [..], o titular do direito [...] incorrerá em responsabilidade civil que, neste caso, por óbvio, é objetiva"); Enunciado n. 37 da I Jornada de Direito Civil promovida pelo Centro de Estudos do Conselho da Justiça Federal: Art. 187: A responsabilidade civil decorrente do abuso do direito independe de culpa e fundamenta-se somente no critério objetivo-finalístico.

148 JAN PETER SCHMIDT, Zivilrechtskodifikation in Brasilien, cit., pp. 464-466.

149 Id., p. 465. 
Já para a função de limitação do exercício de posições jurídicas, a questão não se coloca nos mesmos termos. Se alguém exerce um poder formativo, por exemplo, desrespeitando os limites impostos pela boa-fé, o exercício do direito não é reconhecido pelo ordenamento jurídico, e as sanções de ineficácia ou de invalidade daí defluirão, sem que seja necessário sindicar o elemento subjetivo do agente. ${ }^{150}$

Dessa forma, pode-se afirmar que, se o exercício do direito de voto for abusivo, a sanção de anulabilidade poderá ser imposta sem que, para isso, seja necessário indagar da culpabilidade do credor. Por outro lado, eventual responsabilidade por danos decorrentes do abuso seguirá as regras da responsabilidade civil subjetiva.

\subsubsection{CONHECIMENTO DE OFÍCIO}

A diversidade de consequências jurídicas influencia também na possibilidade de conhecimento de ofício pelo magistrado acerca da ocorrência de abuso do direito. Caso o abuso do direito gere dano a outrem, vige o princípio da inércia, e não cabe ao magistrado apurar de ofício a responsabilidade civil daí decorrente. Por outro lado, caso o abuso do direito se revele como exercício inadmissível de posição jurídica (de pretensões ou de direitos potestativos), o magistrado, ao aplicar a lei, conhecerá de ofício da incompatiblidade entre o exercício da posição jurídica e o ordenamento jurídico, para lhe reconhecer ou negar eficácia ou validade. ${ }^{151}$

\subsubsection{NECESSIDADE DE QUE LIMITES SEJAM EXCEDIDOS "MANIFESTAMENTE"}

Importante requisito legal inserido no artigo 187 do Código Civil para a configuração do abuso do direito é a necessidade de que o agente aja de forma "manifestamente" excessiva aos limites impostos pela função social, pelos bons costumes e pela boa-fé. Como argumenta José de O. Ascensão, o objetivo dessa qualificação é o de evitar que qualquer exercício jurídico pudesse ser objeto de um controle judicial exaustivo, que estimularia uma demasiada litigiosidade. ${ }^{152}$

\footnotetext{
150 Id., p. 466. No mesmo sentido, ANTÓNIo MENEZES CoRdeIRo, Tratado de Direito Civil Português, Parte Geral, Tomo IV, Coimbra, Almedina, 2005, p. 373.

151 António M. Cordeiro, Tratado de Direito Civil Português, Parte Geral, Tomo IV, cit., p. 373.

152 JosÉ DE O. AsCEnSÃo, “A Desconstrução do Abuso do Direito”, cit., p. 40.
} 
No âmbito do abuso do direito de voto pelo credor, tal requisito limita a possibilidade de controle judicial apenas às situações de abuso do direito que impliquem marcado, ou manifesto, desrespeito aos limites da boa-fé, da função social e dos bons costumes.

Cabe, então, analisar quais são esses limites no âmbito da recuperação judicial.

\subsection{LIMITES AO EXERCÍCIO DO DIREITO DE VOTO PELO CREDOR}

Ao deliberarem acerca de um plano de recuperação judicial proposto por um devedor em crise, os credores retêm o poder de influenciar a esfera jurídica do devedor e dos demais credores. Ao aceitar um plano de recuperação proposto pelo devedor, os credores autorizam a concessão de recuperação judicial pelo juízo (LRF, art. 58). Em hipótese oposta, os credores, ao rejeitar o plano de recuperação, determinam a decretação de sua falência (LRF, art. 56, $\S^{\circ}$ ), o que afetará não apenas o devedor, mas terceiros interessados que não sejam formalmente detentores de direitos de crédito e os demais credores, que poderão receber na falência menos do que receberiam na recuperação judicial. À vista dessas distintas repercussões do direito de voto, há três principais perspectivas, não excludentes entre si, que podem ser cogitadas para delinear os limites do exercício regular do direito de voto.

Primeiramente, seria possível defender que, por englobar um poder de alterar a esfera jurídica alheia, o exercício do direito de voto deva ser norteado pelo princípio da preservação da empresa e da promoção de sua função social (LRF, art. 47). O referencial para a determinação da regularidade do exercício do direito de voto, nessa circunstância, seria o respeito ao interesse das diversas partes mencionadas no artigo 47 da LRF.

Um segundo posicionamento possível seria o de afirmar que, em razão de a recuperação judicial ter caráter de contrato, caberia ao credor atuar de boa-fé e de acordo com os bons costumes em relação ao devedor, de forma que os interesses do devedor constituiriam limite ao exercício do direito de voto.

Há, por fim, um terceiro posicionamento, que tem em conta a circunstância de que o credor integra uma comunhão de interesses e, com isso, concorre para a formação de vontade 
coletiva. Deveria, por isso, exercer seu direito de voto pautado pelo dever de lealdade vigente entre os credores.

\subsubsection{DIREITO DE VOTO COMO PODER FUNCIONAL NORTEADO PELA PRESERVAÇÃO DA EMPRESA EM CRISE E PROMOÇÃO DE SUA FUNÇÃO SOCIAL}

Ao determinar que a recuperação judicial "tem por objetivo viabilizar a superação da situação de crise econômico-financeira do devedor, a fim de permitir a manutenção da fonte produtora, do emprego dos trabalhadores e dos interesses dos credores, promovendo, assim, a preservação da empresa, sua função social e o estímulo à atividade econômica" (LRF, art. 47), a lei explicita princípios vetores do sistema recuperacional.

Há, na doutrina estadunidense, marcado debate teórico acerca de quais devam ser os objetivos de um sistema concursal. ${ }^{153}$ Parte da doutrina considera que o único objetivo de uma legislação concursal deve ser a satisfação dos credores. ${ }^{154}$ Outros doutrinadores, por sua vez, defendem que um procedimento concursal não deve promover somente a satisfação dos credores, mas também a manutenção da empresa, a preservação de postos de trabalho e a minimização de impactos sociais decorrentes da crise econômico-financeira. ${ }^{155}$

153 Para uma descrição dos posicionamentos, cf. AXEL FLESSNER, "Philosophies of Business Bankruptcy Law: an International Overview", in JACOB S. ZIEGEL, Current Developments in International and Comparative Corporate Insolvency Law, Oxford, Clarendon, 1994, pp. 19-28; e DougLAS G. BAIRD, “Bankruptcy's Uncontested Axioms", in Yale L. J., vol. 108, n. 3, 1998, pp. 573-599; DONALD R. KOROBKIN, "The Role of Normative Theory in Bankruptcy Debates", in Iowa L. Rev., vol. 82, 1996, pp. 75-126; e VANESSA FINCH, Corporate Insolvency Law, $2^{\mathrm{a}}$ ed., Cambridge, Cambridge University Press, 2009, pp. 3248.

154 Essa corrente doutrinária, alinhada ao movimento de Law and Economics, defende fundamentalmente que o sistema concursal deve se limitar a coordenar a ação coletiva entre os credores, não devendo perseguir nenhum outro objetivo que não o de buscar a maximização da recuperação dos créditos detidos em face do devedor. Cf. Douglas G. BAIRD, THOMAS H. JACKSON, "Corporate Reorganizations and the Treatment of Diverse Ownership Interest: A Comment on Adequate Protection of Secured Creditors in Bankruptcy", in U. Chi. L. Rev., vol. 51, 1984, pp. 97-130; THOMAS H. JACKSON, "Bankruptcy, NonBankruptcy Entitlements, and the Creditors's Bargain”, in Yale L. J., vol. 91, 1982, pp. 857-907; THOMAS H. JACKSON, The Logic and Limits of Bankruptcy Law, Cambridge/London, Harvard, 1986; DougLAS G. BAIRD, "Loss Distribution, Forum Shopping, and Bankruptcy: A Reply to Warren", in U. Chi. L. Rev., vol. 54, 1987, pp. 815-834; MARK J. ROE, "Commentary on "On the Nature of Bankruptcy": Bankruptcy, Priority, and Economics", Va. L. Rev., vol. 75, 1989, pp. 219-240; MiCHAEL BRADLEY, MiCHAEL ROSENZWEIG, "The Untenable Case for Chapter 11", in Yale L. J., vol. 101, 1992, pp. 1043-1095; ROBERT K. RASMUSSEN, DAVID A. SKEEL JR., "The Economic Analysis of Corporate Bankruptcy Law", in ABI L. Rev., vol. 3, 1995, pp. 85-115; AlAN SchwarTz, "A Contract Theory Approach to Business Bankruptcy", in Yale L. J., vol. 107, 1998, pp. 1807-1851.

155 Nessa linha, cf. Elizabeth Warren, "Bankruptcy Policy”, in U. Chi. L. Rev., vol. 54, 1987, pp. 775-814; ElizABETH WARREN, "Bankruptcy Policymaking in an Imperfect World”, in Mich. L. Rev., vol. 92, 1993, pp. 336-387; DONALD R. KOROBKIN, "Rehabilitating Values: a Jurisprudence of Bankruptcy", in Colum. L. Rev., vol. 91, 1991, pp. 717-789; DONALD R. KoROBKIN, "Contractarianism and the Normative 
A lei brasileira adota vetor principiológico que corresponde aos anseios da segunda concepção na medida em que busca a promoção de interesses de diversas partes afetadas pela crise.

O atingimento desses objetivos, contudo, não é tarefa simples. Uma legislação concursal deve buscar ordenar objetivos e interesses diversos envolvidos na crise empresarial. ${ }^{156}$ Como objetivos principais, buscam-se a preservação da empresa viável e a retirada do mercado daquelas que são inviáveis. O problema central é o de determinar quais sejam essas empresas. Ao lado desse objetivo, é necessário conferir tratamento adequado aos interesses de credores, trabalhadores, consumidores, comunidade e do próprio devedor.

Mas, além dessa preocupação que pode ser denominada ex post e que tem por foco as partes afetadas por uma crise empresarial em particular, é necessária a consideração ex ante de interesses de outros agentes não envolvidos na crise, mas que tomam decisões "à sombra" do regramento concursal. O tratamento dado à empresa em crise influencia, em maior ou menor medida, a decisão de financiamento, seja por agentes financeiros (bancos), seja por investidores (acionistas minoritários). Influencia, ademais, a propensão à assunção de riscos e ao empreendedorismo por potenciais empresários. Ao mesmo tempo, deve-se ter cuidado para que o procedimento concursal não seja desvirtuado, com sua utilização oportunista para a extração de benefícios de credores por devedores que não enfrentam situação de efetiva crise empresarial.

Diante disso, faz-se necessário indagar como efetivar esses objetivos, o que será debatido nos itens seguintes.

Foundations of Bankruptcy Law", in Tex. L. Rev., vol. 71, 1993, pp. 541-631; DonALD R. KoroBKIN, "The Role of Normative Theory in Bankruptcy Debates", in Iowa L. Rev., vol. 82, 1996, pp. 75-126; DAVID G. CARLSON, "Philosophy in Bankruptcy", in Mich. L. Rev., vol. 85, 1987, pp. 1341-1389; DAVID G. CARLSON, "Bankruptcy Theory and the Creditors' Bargain", in U.Cin. L. Rev., vol. 61, 1992, pp. 453-509; KAREN Gross, "Taking Community Interests into Account in Bankruptcy: an Essay", in Wash. U. L. Q., vol. 72, 1994, pp. 1031-1048; KAREN GROSS, Failure and Forgiveness: Rebalancing the Bankruptcy System, New Haven/London, Yale University Press, 1997.

156 Elizabeth WarRen, “Bankruptcy Policymaking in an Imperfect World”, cit., pp. 373-377. 


\subsubsection{ABUSO DO DIREITO DE VOTO POR DESRESPEITO À FUNÇÃO SOCIAL}

Uma forma de aplicar a função social da empresa em crise é tomá-la como parâmetro para avaliar a regularidade do exercício do direito de voto pelo credor. O Tribunal de Justiça de São Paulo adotou esse posicionamento em casos que envolviam a rejeição de plano de recuperação judicial por credor que era o único com direito real. Tendo em vista que seu veto não poderia ser superado por meio do procedimento alternativo de aprovação do plano previsto no art. 58 da LRF (cram down), entendeu-se que o plano não poderia ser rejeitado pelo credor que privilegiasse suas inclinações egoísticas em detrimento da preservação da empresa. $^{157}$

Esse posicionamento parte da concepção de que caberia ao magistrado determinar o que seria, no caso concreto, o voto em respeito à função social da empresa. Entretanto, essa não parece ser a melhor forma de concretizar a função social da empresa em crise.

O artigo 47 da LRF enumera objetivos em parte concordantes, mas em parte divergentes, entre si. ${ }^{158}$ Além de múltiplos, esses vetores não são hierarquicamente ordenados. Com isso, a lei adota, no plano principiológico, postura que pode ser denominada de "ecletismo valorativo". ${ }^{159} \mathrm{O}$ ecletismo valorativo tem como vantagem promover uma visão integrativa, adequada à regulação de um fenômeno complexo como a crise empresarial. Por outro lado, não oferece parâmetros axiológicos ou decisórios claros. ${ }^{160}$ Há, ademais,

\footnotetext{
157 "Não se pode admitir validade à rejeição de plano por credor único em determinada classe, apesar dos critérios limitados da cram down brasileira, sob pena de configurar-se abuso no exercício do direito de votar o plano na assembléia-geral sempre que o credor privilegiasse posições excessivamente individualistas, em detrimento dos demais interesses em jogo", e, mais à frente, "[n]ão tendo a Lei n. ${ }^{\circ} 11.101 / 2005$ previsto a hipótese de credor único em determinada classe, penso que o juiz não está impedido de aplicar o princípio maior previsto no art. 47 , a fim de permitir a manutenção da fonte produtora, do emprego dos trabalhadores e dos interesses dos credores, promovendo, assim, a preservação da empresa, sua função social e o estímulo à atividade econômica". TJSP, AI n. 649.192-4/2-00, Câm. Esp. de Fal. e Rec. Jud., REL. DES. ROMEU RICUPERO, v.u., j. 18.08.2009, DJ 28.08.2009. No mesmo sentido, TJSP, AI n. 627.497-4/3-00, Câm. Esp. de Fal. e Rec. Jud., REL. DeS. RoMEU RICUPERO, v.u., j. 30.06.2009, DJ 08.07.2009; e TJSP, AI n. 368.631-4/100, Câm. Esp. de Fal. e Rec. Jud., Rel. DeS. RomeU RICUPERO, v.u., j. 18.08.2009, DJ 28.08.2009.

158 A exposição de motivos da lei enumera ainda outros objetivos diversos da Lei de Recuperação e Falência (cf. Jõ̃o PEDro SCAlZILli, Rodrigo TellecheA, LuIS FEliPE SPINELli, “Objetivos e Princípios da Lei de Falências e Recuperação de Empresas", in Revista Síntese, ano 5, n. 26, 2012, pp. 15-30).

159 VANESSA FINCH, Corporate Insolvency Law, cit., pp. 45-48.

$160 I d .$, p. 47 ("Ecletism, nevertheless, gives rise to not inconsiderable problems. In the fist instance, little assistance is offered to decision-makers on the management of tensions and contradictions between different values or on the way that trade-offs between various ends should be effected. Questions, moreover, are easily begged in choosing which values to invoke or emphasize.").
} 
dificuldades práticas para a aplicação direta da função social da empresa em crise ao caso concreto.

Em primeiro lugar, faltam dados ao magistrado. Se é necessário aferir o respeito aos interesses de todas as partes envolvidas (mencionadas no artigo 47 da LRF) e, sobretudo, das partes não representadas no processo, seria necessário que o magistrado contasse com dados relativos a essas variáveis. Entretanto, não é possível ao magistrado avaliar o impacto concreto da falência da empresa sobre a concorrência, sobre trabalhadores, sobre consumidores ou, ainda, sobre partes não diretamente afetadas pela crise, como potenciais credores, potenciais investidores, ou potenciais empresários, sem contar com informações e dados pertinentes, relativos a essas variáveis.

Em segundo lugar, mesmo que o magistrado disponha desses dados, questiona-se como será possível contrapor e ponderar analiticamente os interesses heterogêneos envolvidos. Nas palavras de Lorenzo Stanghellini, “quantos euros a mais para os credores vale um trabalhador demitido?"161

O resultado previsível é o de que o recurso à função social da empresa em crise como fundamento decisório traduza, na maioria dos casos, a priorização escamoteada de um determinado objetivo sobre outros igualmente dignos de tutela. ${ }^{162} \mathrm{Com}$ a adoção de um procedimento como esse, não há respeito material ao dever constitucional de fundamentação racional das decisões judiciais (CF, art. 93, IX).

Em que pese a impossibilidade de utilizar a função social da empresa como fundamento para a avaliação da regularidade do exercício do direito de voto, é necessário analisar como é possível dar eficácia ao princípio previsto no artigo 47 da LRF.

161 Lorenzo StANGhellini, LoREnZo STANGHELlini, Le crisi di impresa fra diritto ed economia, Bologna, Mulino, 2007, p. 79: “Como possono infatti ponderarsi due grandezze fra loro eterogenee come il denaro e i posti di lavoro: Quanti euro in più (ai creditori) compensano un lavoratore licenziato?”

162 VANESSA FINCH, Corporate Insolvency Law, cit., p. 47. 


\subsubsection{PROMOÇÃO PROCEDIMENTAL DA FUNÇÃo SOCIAL}

O artigo 47 da LRF não determina que o direito de voto tem por finalidade promover os diversos objetivos previstos, mas que a recuperação judicial tem esse escopo. Há uma relevante diferença.

A composição dos diversos interesses envolvidos na crise empresarial, como já se apontou (item 2.2.1 supra), é tarefa complexa. Antes de exigir que o magistrado intervenha e que, a todo momento, concretize o princípio da função social da empresa em crise, é necessário ter em vista que a Lei de Recuperação e Falência já contempla e protege, de forma procedimental, diversos dos interesses mencionados no artigo 47, independentemente de que seja ou não aprovado um plano de recuperação judicial.

A suspensão de ações e de execuções após o deferimento do processamento de recuperação judicial (garantida pelo art. $6^{\circ}$ da LRF) preserva a unidade produtiva, o que beneficia o devedor e os credores como um todo; ${ }^{163}$ indiretamente, concede tempo para que os demais interessados busquem acomodar seus interesses e não sejam surpreendidos pelo desapossamento repentino do devedor; ${ }^{164}$ permite, ademais, que o devedor tenha condições de expor sua situação aos credores, facilitando o atingimento de soluções consensuais que podem beneficiar o devedor e os credores, mas também terceiros. ${ }^{165} \mathrm{O}$ fato de que nem sempre sejam obtidas soluções consensuais não é decisivo. Cabe à lei garantir um foro para a busca racional de consensos, não ditar acordos.

A deflagração de um procedimento reorganizativo antes que a crise econômico-financeira alcance estágio irreversível também é importante objetivo que deve ser perseguido para a promoção dos interesses de todas as partes afetadas pela crise empresarial. ${ }^{166}$ É o devedor quem dispõe de melhores condições para identificar o agravamento da crise econômicofinanceira, mas o devedor dificilmente irá sinalizar tal condição se estiver sob ameaça de desapossamento. ${ }^{167}$ Ao garantir a continuidade do devedor na condução da atividade

\footnotetext{
163 THOMAS H. JACKSON, The Logic and Limits of Bankruptcy Law, op. cit., pp. 157-172.

164 ElizABETH WARREN, "Bankruptcy Policy”, cit., p. 788.

165 ElizABETH WARREN, "Bankruptcy Policymaking in an Imperfect World”, cit., pp. 351-352.

166 Id., p. 372.

167 RANDAL C. PICKER, "Voluntary Petitions and the Creditors' Bargain", in U. Cin. L. Rev., vol. 61, 1992, pp. 519-541, p. 523.
} 
empresarial (LRF, art. 64), a lei contribui para minimizar os efeitos da crise, também independentemente da aprovação de plano de recuperação judicial.

A possibilidade de manutenção do devedor à frente das operações da empresa em crise, por fim, favorece a continuidade da atividade produtiva, pois o devedor normalmente conta com conhecimentos específicos, de que um gestor judicial dificilmente disporia.

Percebe-se, com isso, que a lei já permite, de certa forma, a promoção dos objetivos mencionados no artigo 47 da LRF, seja ou não aprovado um plano de recuperação judicial. Todavia, é certo que o artigo 47 não tem apenas teor descritivo. Ele tem como função principal prescrever soluções e deve pautar o intérprete na avaliação crítica da ponderação de interesses promovida pela lei.

Pode-se, assim, considerar que interesses de terceiros não são adequadamente protegidos pelo procedimento concursal. Com base nisso, podem ser advogadas soluções legislativas, ou mesmo interpretativas, tendentes a internalizar esses interesses. ${ }^{168}$

O que se deve ter em vista é que a promoção dos objetivos mencionados no artigo 47 da LRF, seja por meio de alterações legislativas, seja por meio de interpretações teleológicas, exige a transposição da proteção material que se deseja conferir às diversas partes afetadas pela crise empresarial para o procedimento da recuperação judicial. ${ }^{169}$

\subsubsection{SÍNTESE E POSICIONAMENTO}

Dessa forma, parece inadequada a consideração de que o exercício do direito de voto pelo credor deva ser limitado pela função social da empresa em crise ou deva ter por objetivo promover os interesses das diversas partes afetadas pelo procedimento. O princípio da função social da empresa em crise deve ser internalizado por meio de soluções

\footnotetext{
168 SheIla C. N. CerezetTI, A Recuperação Judicial de Sociedade por Ações - O Princípio da Preservação da Empresa na Lei de Recuperação e Falência, cit., pp. 203-238.

169 Calixto Salomão Filho, in Francisco S. De Souza Junior, Antônio Sérgio A. DE M. Pitombo (coord.), Comentários à Lei de Recuperação de Empresas e Falência, cit., pp. 49-50; SHEILA C. N. CEREZETTI, A Recuperação Judicial de Sociedade por Ações - O Princípio da Preservação da Empresa na Lei de Recuperação e Falência, cit., pp. 240-243.
} 
procedimentais; não deve ser transposto de forma direta e tópica pelo magistrado no âmbito da avaliação de eventual abuso do direito de voto pelo credor.

Não é necessário, portanto, exigir dos credores mais do que a preocupação honesta e leal com a satisfação de seu crédito. ${ }^{170} \mathrm{Se}$ os credores perseguirem esse objetivo, cumprem seu papel no procedimento. ${ }^{171}$

Garantir que as soluções obtidas a partir da confluência entre o "egoísmo" de devedor e "egoísmo" de credores sejam consentâneas com os interesses declarados no artigo 47 é questão que compete à estruturação do processo deliberativo. Não é necessária a imposição aos credores de um dever de proteger a função social da empresa ${ }^{172}$ - que, na melhor das hipóteses, representaria postura demagógica, e, na pior delas, fundamento teórico para a imposição de decisões arbitrárias. ${ }^{173}$

\subsubsection{DIREITO DE VOTO LIMITADO POR BOA-FÉ EM RELAÇÃO AO DEVEDOR}

A natureza jurídica do plano de recuperação judicial é de complexa determinação. Apesar de a recuperação judicial ser um instituto novo no direito brasileiro, é possível traçar

170 Tal é o entendimento predominante nos Estados Unidos, como registra CHARLES J. TABB: "Obviously, a creditor or equity security holder that simply does not like the terms of the plan is free to vote against the plan. There is general agreement that voters are allowed to indulge their own selfish motivations. Indeed, creditors and equity holders are expected to try to get all that they can under the plan, and may vote against a plan that does not give them as large a slice of the reorganization pie as they want. The fundamental nature of plan negotiations is that different groups of claimants and equity holders will threaten to vote against a plan unless their share is sweetened, and making such threats is not bad faith." (The Law of Bankruptcy, $2^{\mathrm{a}}$ ed., New York, Foundation Press, 2009, §11.21, p. 1127).

171 Mesmo na doutrina norte-americana que defende que a legislação concursal deve ser pautada pela busca da satisfação de diversos interesses, nega-se que o juiz deva decidir com base no interesse público. Confira-se o posicionamento de ELIZABETH WARREN, uma das principais representantes da linha denominada traditionalist, que considera que o procedimento concursal deve internalizar uma ampla gama de interesses: "Should a judge base a specific decision on the interests of those parties without formal legal rights? Some judges believe they can discern and protect the public interest. I would argue that they should not go beyond the statutory mandate to permit a reorganization effort bounded by enumerated legal constraints. To enlarge those rights beyond the estate's opportunity to reorganize risks upsetting the balance of interests established by the legislature." ("Bankruptcy Policymaking in an Imperfect World", cit., p. 356, nota 47 - considera, contudo, que, de lege ferenda, outra solução seria desejável).

172 Nesse sentido, afirma ROBERTO SACCHI, tendo em vista o procedimento de concordato italiano "[...] non si chiede affatto al creditore di superare il suo egoismo, il che implicherebbe una inammissibile trasformazione del diritto di voto in droit-fonction [...]" ("Dai soci di minoranza ai creditori di minoranza", cit., p. 1071).

173 Um dos instrumentos de que os tribunais nazistas se utilizaram para a conformação do direito às ideologias do partido foi a doutrina do abuso do direito de Siebert (jurista ligado ao partido nacionalsocialista), que defendia que todos os direitos são concedidos pelo ordenamento jurídico para a persecução de uma finalidade social, entendida, no período nazista, como a função que atendia aos "interesses do povo" (BERND RÜTHERS, Die unbegrenzte Auslegung, 6 ${ }^{\mathrm{a}}$ ed., Tübingen, Mohr Siebeck, 2005, pp. 345-351). 
paralelos estruturais entre a recuperação judicial e a concordata, ${ }^{174}$ sobretudo antes da vigência do Decreto-Lei n. 7.661/45. Dentre as diversas teorias acerca da natureza jurídica da concordata, úteis para a determinação da natureza jurídica da recuperação judicial, destacam-se: ${ }^{175}$ (i) a teoria processualista; (ii) a teoria da obrigação legal; e (iii) a teoria contratualista.

Certamente, pode-se objetar à tese contratualista o fato de que não seja necessária a concordância efetiva de todos os credores para que um plano de recuperação seja aprovado. Todavia, por mais que se afaste do conceito clássico de contrato, o plano de recuperação judicial apresenta conteúdo negocial, permitindo a modelagem de efeitos jurídicos pelas partes. Já quanto à exigência de declaração de vontade, ainda que não se exija a aceitação por cada um dos credores, é necessária a aceitação por maioria (LRF, art. 45 c/c art. 58). O plano de recuperação judicial, com isso, pode ser considerado negócio jurídico ${ }^{176}$ de caráter contratual, ainda que com determinadas especificidades.

Nessa perspectiva, a aceitação ou rejeição do plano de recuperação judicial pelos credores inscreve-se na fase de celebração contratual. Os credores, ao exercerem seu direito de voto, participam de procedimento de formação da vontade coletiva da comunhão de credores, em que devem guardar, para com o devedor, os princípios da probidade e da boa-fé (CC, art. 422). Ademais, por conta do artigo 187 do CC, não podem os credores agir de forma contrária à função social e aos usos e costumes.

Para analisar a questão de forma mais clara e concentrada sobre os efeitos decorrentes da relação bilateral entre devedor e cada um dos credores, pode-se partir da hipótese (manifestamente acadêmica) da recuperação judicial de uma empresa que conte com apenas um credor. Nesse caso, cabe refletir quais seriam os deveres impostos ao credor na

\footnotetext{
174 Mauro Rodrigues Penteado, in Francisco S. De Souza Junior, Antônio Sérgio A. De M. PITOMBo (coord.), Comentários à Lei de Recuperação de Empresas e Falência, cit., p. 86.

175 Rubens Requĩ̃o, Curso de Direito Falimentar, vol. 2, 14ª ed., São Paulo, Saraiva, 1995, pp. 12-15. Tratando da natureza jurídica do plano de insolvência (Insolvenzplan) no direito alemão, cf. EIKE HAPPE, Die Rechtsnatur des Insolvenzplans, Köln/Berlin/München, Carl Heymanns, 2004 (defendendo a natureza contratual); STEPHAN MADAUS, Der Insolvenzplan, Tübingen, Mohr Siebeck, 2011, pp. 7-432 (defendendo a natureza contratual); DIETER LEIPOLD, "Zur Rechtsnatur des Insolvenzplans", in KTS, n. 2, 2006, pp. 109126 (negando parcialmente a natureza contratual).

176 É o posicionamento de MAURo Rodrigues PENTEAdo (in Francisco S. DE SOUZA JUNIOR, Antônio SÉrgio A. DE M. PItOMbo (coord.), Comentários à Lei de Recuperação de Empresas e Falência, cit., p. 86).
} 
votação de um plano de recuperação judicial, bem como se estaria sujeito a um eventual dever de concordar com determinada proposta de recuperação judicial.

Caso a recuperação judicial seja considerada como um contrato, é certo que seus efeitos são bastante peculiares. Sua não celebração conduz a um efeito grave, que é a imediata decretação da falência do devedor (LRF, art. 56, § $\left.4^{\circ}\right)$.

Entretanto, somente votam acerca do plano de recuperação judicial credores que terão as condições originais de seu crédito alteradas (LRF, art. $45, \S 3^{\circ}$ ). A deliberação acerca do plano não é uma análise abstrata de viabilidade, mas um negócio jurídico que tem por efeito a novação do crédito (LRF, art. 59). O contrato de mútuo, por sua vez, é contrato de caráter intuitu personae, condição ostentada também por um contrato de renegociação de crédito, função exercida pelo plano de recuperação judicial.

Na França, na Bélgica e na Alemanha, a doutrina discutia, na década de 1970, questão que guarda pontos de contato com a questão aqui versada, embora com certa peculiaridade. Trata-se da possível responsabilidade de bancos que mantêm relação de financiamento contínuo com determinado devedor e, em dado momento, decidem cessar o financiamento da atividade empresarial, por considerarem que o devedor não terá condições de adimplir ao crédito, mesmo sabendo que essa decisão provavelmente levará à falência do devedor. Klaus Hopt, em estudo de direito comparado, apontou que, na França e na Bélgica, reconhecia-se o caráter intuitu personae do contrato de concessão de crédito, razão pela qual o banco não poderia ser obrigado a fornecer crédito a um devedor que não julgasse meritório, mesmo que isso ocasionasse a falência do devedor. ${ }^{177} \mathrm{O}$ mesmo posicionamento prevalecia na Alemanha. ${ }^{178}$

177 KLAUS HOPT, "Rechtspflichten der Kreditinstitute zur Kreditversorgung, Kreditbelassung und Sanierung von Unternehmen - Wirtschafts und bankrechtliche Überlegungen zum deutschen und französischen Recht”, in ZHR, vol. 143, pp. 139-173, pp. 166-167.

$178 I d$., p. 168. Em estudo constante do mesmo volume da revista, CLAUS-WILHELM CANARIS extrai conclusão parcialmente diversa para o banco que já mantenha relação contínua de financiamento a um determinado devedor (atuando como Hausbank). Segundo o autor, seria possível extrair da proibição do abuso do direito e do dever de boa-fé a conclusão de que um banco estaria obrigado a conceder financiamento de curto prazo (por exemplo, crédito para ilidir o protesto de título) para evitar a falência do devedor que financie constantemente, caso este ofereça garantias suficientes ao crédito ("Kreditkündigung und Kreditverweigerung gegenüber sanierungsbedürftigen Bankkunden”, in ZHR, vol. 143, 1979, pp. 113138, pp. 132-133). Contudo, deve-se ter em mente que: (i) a análise se baseia na especial relação de confiança e dependência em que um devedor se situa quando mantém relação comercial com apenas um banco (Id., p. 126), algo que era e é comum na Alemanha; (ii) a tese se limita a impor a concessão de crédito emergencial de curto prazo, negando qualquer obrigação de concessão de créditos adicionais; e (iii) a tese foi 
$\mathrm{O}$ argumento deve ser ponderado também sob o direito brasileiro. Se o objetivo do procedimento de recuperação judicial é a busca de soluções consensuais resultantes do exercício da autonomia privada pelo devedor e pelos credores, tal resultado deve ser decorrente da análise do credor acerca da viabilidade do devedor. A afirmação de que os credores estariam sujeitos a um dever de aceitar alterações a seu crédito para alcançar uma solução recuperacional não parece consentânea com esse objetivo.

Há, contudo, limites à decisão do credor, mesmo que único. Para que o plano seja aceito, não é possível a prática de ato contrário aos usos e costumes, como a exigência de que o devedor pratique ato ilegal (imagine-se a exigência de financiamento ilegal de campanha política, por exemplo). Na mesma medida, a função social do direito de voto poderia ser defraudada caso o credor buscasse, por meio do exercício do direito de voto, simplesmente garantir a falência do devedor, cujos clientes aborda, em prática de concorrência desleal. Por fim, embora a boa-fé não fundamente um dever de concordar com um plano de recuperação judicial proposto pelo devedor, pauta toda a atuação dos credores para com o devedor, impondo deveres laterais de informação e de consideração.

\subsubsection{DiReito DE VOTO Limitado PELO DEVER DE LEALdAdE ENTRE OS CREDORES}

A principal limitação imposta ao exercício do direito de voto pelo credor decorre do dever de lealdade.

Como já se explicitou, os credores integram uma comunhão de interesses (item 1.1.4, supra), em que o voto exercido por cada um dos credores concorrerá para a formação de uma vontade coletiva que terá efeitos sobre todos os seus integrantes. Com base no dever de boa-fé e no princípio geral de correlação entre poder e responsabilidade, tornam-se os credores destinatários de um dever de lealdade em relação aos demais (item 1.2, supra).

objeto de fortes críticas pelos riscos que imporia à estabilidade bancária (DIETRICH RÜMKER, "Verhaltenspflichten der Kreditinstitute in der Krise des Kreditnehmers", in KTS, n. 4, 1981, pp. 493-512, pp. 503-506). 
Sendo o dever de lealdade desdobramento do dever de boa-fé, e consistindo a boa-fé em limite no exercício de posições jurídicas (CC, art. 187), é possível considerar que o descumprimento de um dever de lealdade societário ou existente em uma comunhão de interesses representa abuso do direito. ${ }^{179}$

Ao afirmar que o credor, ao exercer seu direito de voto, deverá ser leal à comunhão de credores e aos demais credores individualmente considerados, não se afirma que o direito de voto deva ser transformado em um poder funcional, tampouco que o credor deva buscar decifrar um suposto interesse comum da comunhão de credores para que possa exprimir seu direito de voto. O voto é direito concedido ao credor para a persecução de seus próprios interesses. Cabe a cada credor expressar sua convicção quanto à viabilidade da empresa em crise, das propostas traçadas no plano para seu soerguimento, bem como avaliar se aceita o sacrifício imposto pela alteração das condições de seu crédito. Mas o dever de lealdade se impõe como limite ao exercício desse direito.

Há abuso do direito de voto quando o credor descumpre seu dever de lealdade ${ }^{180}$ para com a comunhão dos credores e para com os demais credores individualmente considerados. As hipóteses concretas em que isso pode ocorrer serão analisadas ao longo do capítulo 4, infra.

\subsection{EXCURSO: NECESSÁRIA ANÁLISE PRÉVIA DA LEGALIDADE DO PLANO PARA A CORRETA APLICAÇÃO DO ABUSO DO DIREITO DE VOTO}

Antes da análise da legalidade do exercício do direito de voto em assembleia geral de credores, é necessária a verificação da legalidade do próprio plano proposto pelo devedor. O tema não está diretamente relacionado ao abuso do direito de voto, sendo por isso denominado como excurso, mas é um pressupoto para a aferição do abuso do direito de voto. Isso porque, entre as consequências do abuso do direito de voto, está a invalidade do

\footnotetext{
179 Considerando que o descumprimento ao dever de lealdade (no caso, societário) representa abuso do direito, cf. JOACHIM HENNRICHS, "Treupflichten im Aktienrecht - zugleich Überlegungen zur Konkretisierung der Generalklausel des §242 BGB sowie zur Eigenhaftung des Stimmrechtvertreters”, cit., p. 230; e MARCUS LUTTER, "Die Treupflicht des Aktionärs - Bemerkungen zur Linotype Entscheidung des BGH”, in ZHR, vol. 153, 1989, pp. 446-471, pp. 457-458.

180 Embora em outro contexto, ERASMO V. A. E N. FRANÇA apontou que "os conceitos de abuso do direito de voto e de conflito de interesses são distintos, mas, da maneira como o legislador os dispôs, na Lei 6.404, eles se interligam" (Conflito de Interesses nas Assembléias de S.A., Malheiros, São Paulo, 1993, p. 93).
} 
voto proferido pelo credor $(5.1$, infra). Entretanto, se o processo deliberativo não for estruturado adequadamente, mesmo o credor que abusa do direito de voto poderá sofrer sérios danos a seus interesses, que serão agravados com a invalidade do voto.

\subsubsection{PRINCIPAIS ILEGALIDADES NO PLANO DE RECUPERAÇÃo JUDICIAL}

Um plano de recuperação judicial pode ser ilegal por não atentar para os requisitos impostos na Lei de Recuperação e Falência. Entre as diversas hipóteses de ilegalidade, duas concernem diretamente à integridade do processo deliberativo e serão aqui abordadas. Trata-se da possibilidade de que o plano ofereça aos credores nível informacional deficiente e de que o plano outorgue tratamento não equitativo (ou discriminatório) a determinados credores.

\subsubsection{DEFICIÊNCIA INFORMACIONAL}

No processo de recuperação judicial o devedor deve prestar informações aos credores no momento em que requer o deferimento da recuperação judicial e também no curso do procedimento de recuperação judicial.

Para o processamento da recuperação judicial, deve o devedor apresentar requerimento que exponha as causas concretas de sua situação patrimonial e as razões da crise econômicofinanceira (LRF, art. 51, I); demonstrações contábeis relativas aos três últimos exercícios sociais e as especialmente levantadas para instruir o requerimento (LRF, art. 51, II), acompanhadas de extrato de suas contas bancárias e aplicações financeiras (LRF, art. 51 VII); relação dos credores com detalhamento da natureza dos débitos (LRF, art. 51, III) e das ações judiciais em que figure como parte, com estimativa dos valores demandados (LRF, art. 51, IX); relação dos empregados (LRF, art. 51, IV); relação dos bens particulares dos sócios controladores e dos administradores do devedor (LRF, art. 51, VI); e certidões de regularidade junto ao Registro Público de Empresas (LRF, art. 51, V) e dos cartórios de protestos onde o devedor tiver sua sede e filiais (LRF, art. 51, VIII).

Caso a documentação acima relacionada esteja "em termos" (LRF, art. 52, caput), o juiz deferirá o processamento da recuperação judicial. Durante a tramitação do processo de recuperação, cabe ao devedor apresentar contas demonstrativas mensais, sob pena de 
destituição de seus administradores (LRF, art. 52, IV), e os credores podem constituir comitê de credores, que terá por função fiscalizar as atividades do devedor e as contas do administrador judicial (LRF, art. 27, I, “a”).

A informação é elemento essencial para que os credores possam tomar decisões seguras, com a necessária ponderação dos riscos e dos benefícios envolvidos na aceitação de um plano de recuperação judicial. ${ }^{181} \mathrm{Se}$ o procedimento de recuperação judicial aloca aos credores a importante decisão acerca da viabilidade do devedor e se cabe aos credores aceitar ou não alterações às condições originais de seus créditos com base em informações prestadas pelo devedor, não bastam quaisquer informações; informações adequadas são imprescindíveis para a regular estruturação do processo decisório. ${ }^{182}$

Problemas podem surgir, portanto, se as informações previstas em lei não forem prestadas, ou se forem prestadas de forma materialmente insuficiente. Se isso ocorrer, cabe indagar quais poderes dispõem o magistrado, os credores ou o Ministério Público para exigir que as informações sejam fidedignas.

Na jurisprudência paulista, prevalecia o entendimento de que, se as informações prestadas pelo devedor não fossem adequadas, caberia exclusivamente aos credores manifestar sua objeção ao plano de recuperação no prazo de trinta dias (LRF, art. 55, caput). À assembleia-geral de credores caberia avaliar o plano apresentado, e, se o aceitasse, isso significaria que os credores se contentaram com as informações prestadas. Embora o Ministério Público tenha legitimidade para recorrer da decisão que conceder a recuperação judicial (LRF, art. 59, $\S 2^{\circ}$ ), entendeu o Tribunal de Justiça de São Paulo que o parquet não teria legimidade para questionar a regularidade do processamento da recuperação judicial, mesmo que tivesse por inatendidos os requisitos informacionais constantes do art. 51 da LRF. ${ }^{183}$ Entendeu, ademais, que a tarefa tampouco deve ser realizada pelo magistrado, a quem "não compete [...] aferir a realidade das informações contábeis e financeiras

181 Emanuelle U. MafFioletti, Sheila C. N. Cerezetti, "Transparência e Divulgação de Informações nos Casos de Recuperação Judicial de Empresas”, in NEWTON DE LUCCA, ALESSANDRA DE A. Domingues, Nilva M. L. AnTONIO (coord.), Direito Recuperacional - Volume 2: Aspectos Teóricos e Práticos, São Paulo, Quartier Latin, 2012, pp. 79-105, p. 81.

$182 \quad$ Id., p. 91

183 TJSP, AI n. 500.624.4/8-00, Câm. Esp. de Fal. e Rec. Jud., REl. DeS. Lino Machado, v.u., j. 26.03.2008, DJ 01.04.2008. 
constantes dos documentos que instruem a inicial". ${ }^{184}$ Segundo esse posicionamento, "o exame da documentação que instrui a inicial é formal, e não material ou real". ${ }^{185}$ Adicionalmente, em outra circunstância, decidiu o Tribunal de Justiça de São Paulo que o devedor poderia apresentar, no curso de assembleia geral de credores, aditivo ao plano de recuperação judicial proposto, sem que os credores tenham prévio conhecimento das condições do plano, ${ }^{186}$ nem que tenha sido realizado e apresentado específico laudo dando conta da viabilidade do plano reformulado. ${ }^{187}$

A jurisprudência paulista, ao menos em uma recente decisão, passou a caminhar em sentido parcialmente diverso. Entendeu-se que o juiz pode determinar a realização de perícia prévia para auxiliá-lo no exame da documentação contábil e que é possível ao magistrado constatar in loco a situação da empresa, de modo a averiguar suas reais condições de funcionamento. ${ }^{188}$

Não é possível, no âmbito deste trabalho, examinar qual deve ser o nível mínimo de informações prestadas, devendo-se relevar, ademais, que a conformação do sistema concursal, nesse particular, não deve descuidar de efeitos concorrenciais e de mercado de capitais que podem advir de uma exposição extremamente ampla dos dados do devedor,

184 TJSP, AI n. 994.09.282242-5, Câm. Res. Fal. e Rec., Rel. Des. Pereira CAlÇAS, v.u., j. 06.04.2010, DJ 22.04.2010.

185 TJSP, AI n. 612.654-4/6-00, Câm. Esp. de Fal. e Rec., REl. DeS. PEREIRA CALÇAS, v.u., j. 18.08.2009, DJ 28.08.2009. No mesmo sentido, TJSP, AI n. 520.208-4/6-00, Câm. Esp. Fal. Rec. Jud., REL DES. LINO MACHADO, v.u., j. 07.05.2008, DJ 20.05.2008.

186 TJSP, AI n. 459.929.4/7-00, Câm. Esp. Fal. Rec. Jud., Rel. DeS. Boris KauffMANn, v.u., j. 06.12.2006, DJ 12.12.2006.

187 “As alterações que o plano originalmente aprovado venham a sofrer na assembléia-geral não exigem novo estudo de viabilidade econômica, ou a abertura de prazo para estudo e apresentação de objeção" (TJSP, AI n. 493.240.4/1-00, Câm. Esp. Fal. Rec. Jud., Rel. DeS. Boris KaufFMAnN, v.u., j. 01.08.2007, DJ 08.08.2007).

188 Cf. a ementa do julgado: "RECUPERAÇÃO JUDICIAL. Pedido de processamento. Determinação de realização de perícia prévia, para auxiliar o juízo na apreciação da documentação contábil (art. 51 II LRF) e constatar a real situação de funcionamento da empresa. Possibilidade. Decisão mantida. Assistência técnica de perito permitida pela lei. Juiz que não dispõe de conhecimentos técnicos suficientes para apreciar a regularidade da documentação contábil apresentada. Art. 189 LRF c/c art. 145 CPC. Com relação à constatação da real situação de funcionamento da empresa, não pode o julgador mostrar-se indiferente diante de um caso concreto, em que haja elementos robustos a apontar a inviabilidade da recuperação ou mesmo a utilização indevida e abusiva da benesse legal. O princípio da preservação da empresa não deve ser tratado como valor absoluto, mas sim aplicado com bom senso e razoabilidade, modulado conforme a intenção do legislador e espírito da lei. Ativismo. Precedentes. Decisão de deferimento do processamento que irradia importantes efeitos na esfera jurídica de terceiros. Decisão integralmente mantida por seus próprios e jurídicos fundamentos. Recuso desprovido." (TJSP, AI n. 0194436-42.2012.8.26.0000, $1^{\text {a }}$ Câm. Res. de Dir. Emp., REL. DES. TEIXEIRA LEITE, j. 02.10.2012, DJ 06.10.2012.). 
nem pode, por outro lado, exigir informações cuja reunião seja tão complexa que imponha ao devedor custos impeditivos. ${ }^{189}$

De toda forma, se o plano não for acompanhado de informações mínimas, há desrespeito a interesses legítimos dos credores, que se veêm impossibilitados de deliberar com base em elementos concretos que permitam a análise da situação do devedor em crise. Há, com isso, ilegalidade, que deve ser saneada.

\subsubsection{TRATAMENTO DISCRIMINATÓRIO}

Na LRF, a assembleia-geral de credores é composta por três classes de credores, que deliberam por maioria acerca do plano de recuperação judicial. Contudo, dada a peculiaridade da comunhão de interesses composta pelos credores, especificamente pela multiplicidade de interesses de que são titulares, o funcionamento da regra majoritária pressupõe uma estrutura deliberativa que contemple (i) a organização de credores em classes com mínima homogeneidade de interesses; e (ii) tratamento equitativo entre componentes de uma classe. A Lei de Recuperação e Falência, contudo, não estrutura o processo deliberativo em atenção a esses princípios. ${ }^{190}$

\subsection{CLASSES DE CREDORES COM INTERESSES HETEROGÊNEOS}

No processo de recuperação judicial, a deliberação sobre o plano de recuperação judicial se dá por meio da separação dos credores em três classes. Integram a primeira classe os credores titulares de créditos derivados da legislação do trabalho ou decorrentes de acidentes de trabalho (LRF, art. 41, I); a segunda, os titulares de créditos com garantia real (LRF, art. 41, II); a terceira, os titulares de créditos quirografários, com privilégio especial, com privilégio geral, ou subordinados (LRF, art. 41, III).

\footnotetext{
189 Remete-se, aqui, ao já mencionado estudo de EMANUELle U. MAfFioletti e Sheila C. N. CEREZETTI, que realiza essa necessária ponderação de interesses e faz sugestões para o aprimoramento do trato da matéria ("Transparência e Divulgação de Informações nos Casos de Recuperação Judicial de Empresas", cit.).

190 Sheilla C. N. Cerezetti, “As Classes de Credores como Técnica de Organização de Interesses: em Defesa da Alteração da Disciplina das Classes na Recuperação Judicial”, in PAUlo FERnANDo C. S. DE Toledo, Francisco SATIRo (coord.), Direito das Empresas em Crise: Problemas e Soluções, São Paulo, Quartier Latin, 2012, pp. 367-385.
} 
Nota-se, em primeiro lugar, que o único critério utilizado pela lei para a separação dos créditos em classes é a natureza do crédito, sem atentar para circunstâncias pessoais dos credores. Entretanto, é possível, e mesmo recorrente, que titulares de crédito de uma mesma natureza tenham interesses divergentes e, por vezes, incompatíveis. ${ }^{191}$ Pense-se na diversidade de interesses entre fornecedores, interessados na manutenção da empresa e credores que não mantêm relacionamento comercial contínuo com o devedor. Ou entre empregados atuais, que buscam a manutenção de seus postos de trabalho, e empregados demitidos que busquem o reconhecimento de crédito de natureza indenizatória de elevada monta.

Em segundo lugar, nem mesmo o critério de separação dos créditos de acordo com sua natureza foi seguido com rigor. Especificamente na classe III, há justaposição de titulares de créditos a que a lei falimentar atribui diversa prioridade na hipótese de falência. No art. 83 da LRF, estatui-se que, na falência, serão primeiro satisfeitos os credores com privilégio especial e depois, em ordem, os credores titulares de privilégio geral, de créditos quirografários e de créditos subordinados (LRF, art. 83, IV, V, VI e VIII).

Ao analisar um plano de recuperação judicial, cada credor compara a proposta de satisfação a seu crédito apresentada pelo devedor com aquela a que faria jus na hipótese de falência. Se o referencial de comparação entre os credores é diverso, diverso também será o sacrifício a que se sujeitará cada um dos credores, caso seja adotada solução única para todos os integrantes da mesma classe.

A formação de classes de credores com interesses homogêneos, técnica adotada em legislações concursais de outros países, é motivada pela constatação de que o princípio majoritário somente pode atuar adequadamente se houver uma mínima homogeneidade entre os interesses dos integrantes do grupo, de forma a permitir que a maioria seja representativa da minoria. ${ }^{192}$ Caso contrário, será possível que integrantes de um grupo

191 Sheila C. N. CEREZETTI, “As Classes de Credores como Técnica de Organização de Interesses: em Defesa da Alteração da Disciplina das Classes na Recuperação Judicial”, cit., p. 372.

192 MASSIMO FABIANI, "Brevi riflessioni su omogeneità degli interessi ed obbligatorietà delle classi nei concordati", Il Fallimento, n. 4, 2009, pp. 437-445, p. 440 ("Se vogliamo dare peso al valore della autonomia privata e dunque alla forza del consenso, è doveroso creare le condizioni per una condivisione della ragione del consenso, ragione que non può coincidere con la frammentazione del ceto creditorio secondo interessi economici omogenei"); ROBERTO SACCHI, "Dai soci di minoranza ai creditori di minoranza", cit., p. 1067; GIOVANNI LO CASCIO, "Concordati, classi di creditori ed incertezze interpretative", in Il Fallimento, n. 10, 2009, pp. 1129-1136, p. 1133; MASSIMO FABIANI, Contratto e processo nel concordato fallimentare, Torino, 
decidam alterar a posição jurídica de outros credores com interesses diversos, o que é incompatível com a proteção à propriedade privada. ${ }^{193}$

Ao prover tratamento diferenciado aos credores com posições jurídicas ou interesses econômicos diferenciados, observa-se também o princípio da igualdade, constitucionalmente reconhecido, e que vige em todas as coletividades, inclusive na comunhão de interesses. ${ }^{194}$ A concretização do princípio da igualdade, em matéria concursal, impõe a separação de credores em classes de créditos homogêneos. ${ }^{195}$ Como sintetizou Lorenzo Stanghellini, a regra de maioria "não pode ser imposta como um manto de chumbo sobre todos os credores, abarcando-os conjuntamente, mas deve ser estratificada por grupos homogêneos de credores". 196

Da experiência de outros países, sobretudo dos Estados Unidos, ${ }^{197}$ Alemanha, ${ }^{198}$ e Itália, ${ }^{199}$ é possível colher exemplos de formulações alternativas para a constituição de classes de credores. Entre essas alternativas, Sheila Cerezetti destaca o modelo alemão, pautado por uma separação obrigatória dos credores, de acordo com a natureza jurídica do crédito (InsO, §222, 1), seguida por uma separação facultativa de credores com interesse

UTET, 2009, pp. 177-185. Também no direito alemão, aponta HORST EIDENMÜLLER que “a decisão tomada pela maioria dos integrantes de uma classe só conta com uma garantia de correção para todos os integrantes se os interesses de todos os integrantes da classe forem essencialmente iguais" (Unternehmenssanierung zwischen Markt und Gesetz, cit., p. 82: "Eine 'Richtigkeitsgewähr' für alle Gruppenmitglieder besitzt die mit Mehrheit getroffene Gruppenentscheidung nur dann, wenn die Interessen der Gruppenangehörigen im wesentlichen gleich sind").

193 LUIGI ABETE, "Il ruolo del giudice ed il principio maggioritario nel novello concordato preventivo: brevi note", in Il Fallimento, n. 03, 2008, pp. 253-258, p. 257.

194 Neste sentido, apontou GÖTZ HUECK que o princípio da igualdade em direito privado é decorrência do dever (jusnatural) de justiça, positivado constitucionalmente. O princípio da igualdade tem aplicação em todos os grupos privados, e também nas comunhões de interesses. (Der Grundsatz der Gleichmässigen Behandlung im Privatrecht, cit., p. 170: "Jede Verbindung mehrerer Personen zu einer rechtlichen anerkannten Gemeinschaft, mag diese auch wie bei den schlichten Interessengemeinschaften nur in loser Form und nur für kurze Zeit bestehen, führt zur Entstehung rechtlicher Gleichbehandlungspflichten [...]").

195 CARSTEN JUNGMANN, "Sachgerechte oder willkürliche Gruppenbildung im Insolvenzplan (Anmerkung zu LG Mühlhausen, Beschluss vom 17.09.2007 - 2 T 190/06)”, in KTS, n. 2, 2008, pp. 210-226, p. 220.

196 LORENZO STANGHELlini, Le crisi di impresa fra diritto ed economia, cit., pp. 224-225: "Ne consegue che la regola di maggioranza non può essere calata come un 'mantello di piombo' su tutti i creditori e abbraciarli tutti insieme, ma deve essere stratificata per gruppi omogenei di creditori”.

197 SCOTT F. NORNBERG, "Classification of Claims Under Chapter 11 of the Bankruptcy Code: The Fallacy of Interest Based Classification”, in Am. Bankr. L. J., vol. 69, 1995, pp. 119-166.

198 MIRJAM RÜVE, Mehrheitsbeschaffung durch die Gruppenbildung im Insolvenzplan - Eine Untersuchung der Gestaltungsmöglichkeiten des Planerstellers und der Gläubiger sowie der Kontrollmöglichkeit des Gerichts, Hamburg, Dr. Kovač, 2008, pp. 15-65.

199 GIUSEPPE BOZZA, "La facoltatività della formazione delle classi nel concordato preventivo", in Il Fallimento, n. 4, 2009, pp. 424-436. 
econômico comum (InsO, §222, 2). ${ }^{200}$ É certo, por outro lado, que a flexibilidade na formação de classes pode levar a manipulações e a um aumento na necessidade de intervenção judicial para sindicar a adequação da separação entre os credores. De toda forma, parece acertada a posição da autora, que ressalta a necessidade de maior homogeneidade entre os integrantes das classes de credores constantes da Lei de Recuperação e Falência.

Do exposto, é possível afirmar que a Lei de Recuperação e Falência adota sistema rígido de divisão dos credores em classes de créditos de natureza distinta, e que nem este critério é seguido de forma consequente. Em função disso, é possível a coexistência, em uma mesma classe, de credores com interesses marcadamente heterogêneos. Ademais, na classe III, há reunião de credores que contam com prioridade falimentar diversa, razão pela qual a imposição de sacrifício idêntico a todos resultará, materialmente, em sacrifício diverso para cada credor de acordo com sua prioridade falimentar.

\subsection{DESIGUALDADE DE TRATAMENTO ENTRE INTEGRANTES DE UMA CLASSE}

A Lei de Recuperação e Falência não exige que os planos de recuperação judicial prevejam pagamento equitativo aos integrantes de uma classe de credores (LRF, art. 45). Se as maiorias previstas nesse artigo não forem atingidas, mas, não obstante, forem cumpridos os requisitos previstos no artigo 58 da LRF, será possível a concessão da recuperação judicial pelo magistrado. Nessa hipótese, contudo, “[a] recuperação judicial somente poderá ser concedida com base no $\S 1^{\circ}$ deste artigo se o plano não implicar tratamento diferenciado entre os credores da classe que o houver rejeitado" (LRF, art. 58, $\S 2^{\circ}$ ). Pode-se questionar, com base nisso, se é possível que o plano confira tratamento diferenciado entre os credores.

A questão tem direta relação com o princípio da igualdade entre os credores (par conditio creditorum) e tem grande relevância prática, pois possibilitaria a propositura de planos que beneficiem certos credores em detrimento de outros. Torna-se possível, com isso, que a maioria de credores, aceitando sacrifícios reduzidos, vincule a minoria, que sofrerá restrições mais gravosas a seu crédito.

200 Sheila C. N. Cerezetti, “As Classes de Credores como Técnica de Organização de Interesses: em Defesa da Alteração da Disciplina das Classes na Recuperação Judicial”, cit., p. 379. 
Paulo Fernando Campos Salles de Toledo, em parecer acerca da legalidade de plano de recuperação judicial que previa tratamento desfavorecido a certos credores e dividia os credores em subclasses não previstas na Lei de Recuperação e Falência, entendeu que o tratamento diferenciado só é possível entre credores componentes de classes distintas. Caso os credores integrem a mesma classe, deverá ser conferido tratamento idêntico a todos. ${ }^{201}$ Aponta o autor, ademais, que tem por inadmissível a formação de subclasses entre os credores integrantes da classe III (prevista no art. 41, III da LRF), mas que, se essa formação fosse tida por possível, seria necessária a votação em separado por cada subclasse, com aceitação do plano por todas elas. ${ }^{202}$

O tema foi objeto de discussão no âmbito da I Jornada de Direito Comercial promovida pelo Centro de Estudos da Justiça Federal, em que se aprovou a adoção de enunciado de n. 57 com o seguinte teor: “[o] plano de recuperação judicial deve prever tratamento igualitário para membros da mesma classe de credores que possuam interesses homogêneos, sejam estes delineados em função da natureza do crédito, da importância do crédito ou de outro critério de similitude justificado pelo proponente do plano e homologado pelo magistrado.”

Na jurisprudência do Tribunal de Justiça de São Paulo, assentou-se o entendimento de que é possível conferir tratamento diferenciado aos credores. ${ }^{203}$ Entretanto, em julgado recente, de lavra do Des. Pereira Calças, adotou-se entendimento diverso. ${ }^{204}$ Tratava-se de plano de recuperação judicial que, entre diversas disposições consideradas ilegais, previa a

\footnotetext{
201 Paulo Fernando C. S. DE TOledo, "Recuperação Judicial - Sociedades Anônimas- Debêntures Assembléia Geral de Credores - Liberdade de Associação - Boa-fé Objetiva - Abuso de Direito - Cram Down - Par Condicio Creditorum", in RDM, vol. 142, 2006, pp. 263-281, p. 276.

$202 \quad$ Id., p. 279.

203 É possível conferir tratamento privilegiado no plano aos fornecedores que tenham mantido relações comerciais com o devedor durante a recuperação judicial: TJSP, AI n. 990.10.031858-6, Câm. Res. Fal. Rec., REL. DES. LiNO MACHADO, v.m., j. 10.08.2010, DJ 23.08.2010 ("não há, em tese, vedação de tratamento diferenciado aos credores que se sujeitem a continuar dando crédito ao devedor numa fase crítica como a que incorre a empresa sob o regime de recuperação judicial"); TJSP, AI n. 0372448-49.2010.8.26.0000, Câm. Res. Fal. Rec., Rel. DeS. PereIRA CAlÇAS, v.u., j. 01.02.2011, DJ 09.02.2011. Entendeu que é possível, na classe III, diferenciar o tratamento conferido aos credores subordinados: TJSP, AI n. 493.240.4/1-00, Câm. Esp. Fal. Rec. Jud., Rel. Des. Boris KAUfFMAnN, v.u., j. 01.08.2007, DJ 08.08.2007. E entendeu que a lei não veda a formação de subclasses entre os credores integrantes de uma classe, mas que, ainda assim, a decisão se dá por maioria: TJSP, AI n. 0136462-81.2011.8.26.0000, Câm. Res. Fal. Rec., REL. DES. ElLIOT AKEL, v.u., j. 18.10.2011, DJ 19.10.2010.

204 TJSP, AI n. 0136362-29.2011.8.26.0000, Câm. Res. Fal. Rec., REL. DES. PEREIRA CALÇAS, v.u., j. 28.02.2012, DJ 28.02.2012.
} 
satisfação em termos privilegiados para os titulares de crédito de menor monta em relação aos credores de maiores valores. Tendo em vista o princípio constitucional da igualdade, e o princípio da pars conditio creditorum, este definido como "pedra angular sobre a qual se assenta qualquer tipo de processo judicial de insolvência”, afirmou-se que a proposta de satisfação diferenciada permite a manipulação do resultado da deliberação assemblear. A manobra é possível pois os credores a quem sejam propostas melhores condições de satisfação vincularão os minoritários, que suportarão sacrifício diverso. Com isso, o tribunal anulou a deliberação, que, derivando da manipulação pelo devedor, foi tida como fraudulenta. ${ }^{205}$

Em julgados posteriores, contudo, não foi alterado o entendimento de que seria possível prever tratamento privilegiado aos credores que mantivessem o fornecimento ao devedor durante a recuperação judicial. ${ }^{206}$ Exige-se, portanto, a adoção de critério de diferenciação que justifique a diferenciação, mas aceita-se que uma maioria que receba maior satisfação vincule a minoria, a quem serão impostas condições mais gravosas.

Já a forma de deliberação do plano que prevê tratamento diferenciado a subclasses de credores foi recentemente objeto de discussão. Tratava-se de plano de recuperação judicial que previa, na classe III, a formação de quatro subclasses de credores, a quem eram propostas diferentes condições de pagamento. A $2^{\text {a }}$ Câmara Reservada de Direito Empresarial do TJSP, nesse caso, reafirmou o entendimento de que é possível a formação de subclasses entre os credores, mas considerou que, sendo conferido tratamento diverso às

\footnotetext{
205 A afirmação da ilegalidade do plano é acertada. Entretanto, não parece adequado o fundamento para a anulação da deliberação (de que haveria vício da deliberação, por ter sido manipulada pelo devedor). A hipótese não seria de vício da deliberação, mas, antes, de vício do plano, que, contendo cláusula ilegal, não deveria ter sido admitido no juízo de deferimento do processamento da recuperação judicial (LRF, art. 52). Apesar de a ilegalidade não ter sido conhecida no momento do deferimento do processamento da recuperação judicial, a matéria é de ordem pública e não preclui, cabendo ao juiz zelar pela regularidade do processo. Dessa forma, constatada em grau de recurso a ilegalidade do plano, a decisão mais adequada seria a anulação da decisão que deferiu o processamento da recuperação judicial e de todos os atos processuais subsequentes, com possibilidade de apresentação de novo plano pelo devedor, resguardados os direitos de terceiros de boafé em aplicação analógica do disposto no art. 39, $\$ 3^{\circ}$ da LRF.

206 TJSP, AI n. 0048861-03.2012.8.26.0000, 2 ${ }^{a}$ Câm. Res. Dir. Emp., Rel. Des. TASso DuARTE DE MELO, v.u., j. 07.08.2012, DJ 09.08.2012, com a seguinte ementa: "RECUPERAÇÃO JUDICIAL. Privilégio de pagamento aos credores dentro da classe quirografários, que permanecem sendo os maiores fornecedores de matéria-prima à recuperanda. Possibilidade. Igualdade material. Princípios constitucionais da função social e da preservação da empresa. Efetivação. Artigo 47 da Lei no 11.101/05. Precedente". No mesmo sentido, TJSP, $2^{a}$ Câm. Res. Dir. Emp., Rel. Des. TASSO DuARTE DE MElo, v.u., j. 16.10.2012, DJ 17.10.2012; TJSP, AI n. 0303530-56.2011.8.26.0000, Câm. Res. Fal. Rec., REL. DES. RICARDO NEGRÃO, v.u., j. 27.11.2012, DJ 29.11.2012; TJSP, AI n. 0198440-25.2012.8.26.0000, $1^{\text {a }}$ Câm. Res. Dir. Emp., REL. DES. MAIA DA CUNHA, v.u., j. 11.12.2012, DJ 11.12.2012.
} 
subclasses, não poderia ser adotada decisão por maioria de credores, contabilizando-se, de forma conjunta e indistinta, credores que não seriam tratados de forma igual. Diante da subdivisão dos credores, seria necessária também a apuração em separado dos votos em cada subclasse, devendo-se "por analogia, obedecer o modo previsto no art. 45". Assim, se três das quatro subclasses fossem favoráveis ao plano, com obtenção de maioria por cabeça e crédito, o plano deveria ser reputado aceito na classe III. $^{207}$

À vista do quanto exposto, mesmo diante do entendimento doutrinário e jurisprudencial que vem prevalecendo, há ainda a possibilidade de serem propostos planos de recuperação iníquos. A previsão de pagamento diferenciado a certos credores em uma classe, ainda que justificada por critérios objetivos como a continuidade de fornecimento, é incompatível com a adoção da regra majoritária, pois não é admissível que credores sujeitos a tratamento diferenciado vinculem outros com interesses diversos. Se for previsto tratamento mais gravoso ao credor minoritário, seu voto não será mecanismo efetivo para a defesa de seus interesses, e sua posição patrimonial será objeto de livre disposição por outros credores que não se sujeitarão aos mesmos sacrifícios. ${ }^{208}$ Já a aplicação do art. 45 da LRF por analogia na hipótese de divisão de credores em subclasses é proposta meritória e inovadora, mas que ainda alberga grande possibilidade de manipulação. Cogite-se, por exemplo, um plano que ofereça condições bastante favoráveis a duas subclasses de credores e forme, por outro lado, uma subclasse de grandes credores que, sabe-se, tendem a ser vinculados pela decisão dos demais pequenos credores. Com a adoção da solução proposta, continuaria aberto o caminho para que os grandes credores fossem vinculados por uma decisão ilegítima, pois adotada por credores que não foram sujeitos à mesma alteração em suas posições jurídicas.

\subsubsection{CONSEQUÊNCIAS PARA A ANÁlISE DO ABUSO DO DIREITO DE VOTO}

Ocorrendo uma situação de ilegalidade pela falta de informações, ou pela sujeição do credor a tratamento não equitativo, é imprescindível que, antes da avaliação de eventual abuso do direito de voto pelo credor, seja analisada a legalidade do plano. Caso contrário, surge a possibilidade de desrespeito a direitos dos credores. Pense-se, por exemplo, no

207 TJSP, AI n. 02.35130-87.2011.8.26.0000, 2a Câm. Res. Dir. Emp., v.u., j. 04.12.2012, DJ 19.12.2012.

208 Nesse sentido, Sheila C. N. CEREzetTI, “As Classes de Credores como Técnica de Organização de Interesses: em Defesa da Alteração da Disciplina das Classes na Recuperação Judicial”, cit., p. 375. 
plano que proponha redução drástica no crédito de apenas um credor, enquanto os demais integrantes de sua classe recebem tratamento favorecido. Se, nessa hipótese, o magistrado não promover um controle de legalidade do plano e, ao mesmo tempo, julgar que o credor abusou de seu direito de voto, ficará o credor cujo voto foi considerado abusivo vinculado a uma maioria que sequer o representa. Os efeitos nefastos da ilegalidade do plano são, então, potencializados.

As considerações acerca do abuso do direito neste trabalho pressupõem, portanto, que haja deliberação sobre plano lícito. 
A Lei de Recuperação e Falência prevê que determinados credores não podem participar da assembleia geral. Com isso, os credores não votam e, naturalmente, não podem abusar do seu direito de voto. Poder-se-ia, portanto, questionar o cabimento de analisar o impedimento de voto $^{209}$ em um trabalho que se dedica ao abuso do direito de voto e que, portanto, pressupõe que o credor terá direito de participar do conclave.

Entretanto, o impedimento de voto é tema que não pode deixar de ser abordado neste trabalho. Primeiramente, porque as hipóteses de impedimento de voto delimitam o âmbito de credores que poderão participar do procedimento deliberativo. Ademais, o impedimento de voto poderia, funcionalmente, proibir o voto de credores que potencialmente abusariam do seu direito de voto. Com isso, impedimento de voto e abuso do direito de voto se mostram como duas formas de garantia da integridade do procedimento deliberativo intimamente relacionadas.

\subsection{HIPÓTESES PREVISTAS NA LEI DE RECUPERAÇ̃̃o E FALÊNCIA}

Têm direito a voto na assembleia geral as pessoas arroladas no quadro-geral de credores ou, na sua falta, na relação de credores apresentada pelo administrador judicial, acrescidas das que estejam habilitadas na data da realização da assembleia ou que tenham créditos admitidos ou alterados por decisão judicial, inclusive as que tenham obtido reserva de importâncias (LRF, art. 39, caput). Há, contudo, previsões de impedimento de voto.

A primeira ordem de hipóteses de impedimento de voto previstas na lei é de caráter objetivo. Não votam titulares de créditos não sujeitos aos efeitos da recuperação judicial, como é o caso do crédito garantido por propriedade fiduciária, ou por arrendamento mercantil ou do crédito concedido sob a modalidade de adiantamento de contrato de câmbio (LRF, art. $\left.39, \S 1^{\circ}\right)$; tampouco votam credores que se sujeitam à recuperação

\footnotetext{
209 Pode-se falar também em proibição de voto. Entretanto, as expressões são empregadas indistintamente por FÁBIO K. COMPARATO ("Controle Conjunto, Abuso no Exercício de Direito de Voto e Alienação Indireta de Controle Empresarial”, in Direito Empresarial: Estudos e Pareceres, São Paulo, Saraiva, 1995, pp. 81-102) e, também no presente trabalho, são utilizadas com o mesmo significado.
} 
judicial, mas que não sofrerão alteração às condições originais de pagamento de seu crédito pelo plano de recuperação judicial (LRF, art. 45, $\S 3^{\circ}$ ). Impede-se, ademais, o voto dos credores retardatários, exceto os credores retardatários trabalhistas (LRF, art. 10, $\S 1^{\circ}$ ). Nessas hipóteses, há pouca polêmica. Nas primeiras, o credor não vota, pois não tem interesse legítimo em participar da deliberação, já que não sofrerá alteração em sua posição jurídica; na última, o credor é sancionado pela demora em habilitar seu crédito - norma que estimula a habilitação tempestiva.

Há, contudo, previsão de impedimento de voto fundada em fatores de ordem subjetiva relacionados ao titular do direito de crédito. Não votam os credores que sejam sócios do devedor nem sociedades que sejam controladoras, controladas ou coligadas com participação superior a 10\% do capital social do devedor ou em que o devedor ou algum de seus sócios detenha participação superior a 10\% do capital social (LRF, art. 43, caput). Tampouco votam os cônjuges ou parentes (consaguíneos ou afins), colaterais até o $2^{\circ}$ grau, ascendentes ou descendentes do devedor, do administrador, do sócio controlador, ou de membro do conselho consultivo, do conselho fiscal, ou de conselho semelhante da sociedade devedora, proibição que se estende às pessoas jurídicas em que um credor impedido de votar exerça alguma dessas funções (LRF, art. 43, par. ún.). Esses credores, apesar de não votarem e de não serem considerados para verificação do quorum de instalação e de deliberação, podem participar da assembleia, com direito a voz (LRF, art. 43, caput).

\subsection{ADEQUAÇÃo DE REGRA DE IMPEDIMENTO DE VOTO NA RECUPERAÇÃo JUDICIAL}

A interpretação da norma prevista no artigo 43 da LRF pressupõe, em primeiro lugar, uma reflexão sobre a adequação de hipóteses de impedimento de voto no procedimento deliberativo acerca do plano de recuperação judicial.

\subsubsection{IMPEDIMENTO DE VOTO NO DIREITO SOCIETÁRIO}

O impedimento do direito de voto é medida altamente restritiva. Por meio do impedimento de voto, o integrante de uma coletividade é excluído do procedimento deliberativo. Presume-se, de forma absoluta, que sua concorrência para a formação da vontade coletiva 
viciará o resultado da deliberação, tendo em vista a presença de certos fatores que afastam sua isenção.

No direito societário, a questão é objeto de grande polêmica no âmbito da lei acionária. A Lei de Sociedades por Ações prevê que o acionista não poderá votar nas deliberações relatvias ao laudo de avaliação de bens com que concorrer para a formação do capital social; à aprovação de suas contas como administrador; nem em quaisquer outras que puderem beneficiá-lo de modo particular, ou em que tiver interesse conflitante com o da companhia (LSA, art. $115, \S 1^{\circ}$ ).

Enquanto as duas primeiras hipóteses são consideradas pacificamente hipóteses de impedimento de voto - e se referem a questões especificamente societárias, sendo, portanto, menos relevantes para o objeto deste estudo -, as duas últimas são objeto de aceso debate. Para parte da doutrina, o conflito de interesses com a companhia imporia ao acionista impedimento de voto; é o que se denomina conflito formal, passível de análise ex ante, e que impede a participação do acionista no conclave. ${ }^{210}$ No entanto, outra parte da doutrina defende que, ocorrendo conflito de interesses entre o acionista e a companhia, o acionista pode votar, estando o voto sujeito a análise ex post de sua compatibilidade com o interesses social; é o que se denominada como conflito material de interesses. ${ }^{211}$ Por fim, o terceiro posicionamento diferencia situações em que se verifica forte perigo de comportamento incorreto, em que haveria conflito de interesses formal, e situações em que isso não ocorre, em que o conflito seria material e avaliado após a deliberação. ${ }^{212}$

210 Modesto Carvalhosa, Comentários à Lei de Sociedades Anônimas, vol. 2, 2. ed., São Paulo, Saraiva, 1998, pp. 410-411.

211 ERASMO V. A. E N. FranÇA, Conflito de Interesses nas Assembléias de S/A, cit., pp. 81-101; Erasmo V. A. E N. FrançA, "O Conceito de 'Benefício Particular' e o Parecer de Orientação 34 da CVM", in Temas de Direito Societário, Falimentar e Teoria da Empresa, São Paulo, Malheiros, 2009, pp. 568-580; LuIZ G. P. DE B. LEÃES, "Proibição de Voto e Conflito de Interesses nas Assembléias-Gerais - Ação de Anulação Decorrente de Voto de Acionista com Interesse Conflitante", in Pareceres, vol. 1, São Paulo, Singular, 2004, pp. 175-184.

212 FÁBIO K. Comparato, "Controle Conjunto, Abuso no Exercício de Direito de Voto e Alienação Indireta de Controle Empresarial”, cit., p. 91 (distinguindo a hipótese de conflito aberto, em que caberia ao presidente da mesa impedir o voto do acionista em conflito, e aquela em que o conflito não transpareça $a$ priori, em que o votante pode exercer o direito de voto, sujeito a controle posterior); e CALIXTO SALOMÃO FILHo, O Novo Direito Societário, $3^{\mathrm{a}}$ ed., São Paulo, Malheiros, 2006, p. 96. 
Como expôs Erasmo Valladão, no direito acionário italiano e alemão, adotou-se a estratégia de limitar as hipóteses de impedimento de voto a questões bem delimitadas e excepcionais, baseadas em precisas circunstâncias formais. ${ }^{213}$

$\mathrm{Na}$ jurisprudência administrativa da Comissão de Valores Mobiliários, o entendimento variou ao longo do tempo: primeiro se entendeu que a regra constante do artigo 115 da LSA impunha o impedimento de voto por conflito formal. ${ }^{214}$ Em momento posterior, alterou-se o posicionamento para considerar que o conflito seria material. ${ }^{215} \mathrm{Na}$ manifestação mais recente a respeito do tema, o entendimento do Colegiado da autarquia foi de que o artigo $115, \S 1^{\circ}$ da LSA prevê hipótese de conflito formal, que impede o acionista de exercer direito de voto em assembleia que delibere sobre a celebração de contrato bilateral em que ele, ou sociedade por ele controlada, figure como contraparte. ${ }^{216}$

A discussão aqui referida assinala para as dificuldades trazidas pela opção do impedimento do direito de voto inclusive em matéria societária, em que a decisão diz respeito à sociedade e apenas mediatamente aos sócios.

\subsubsection{IMPEDIMENTO DE VOTO NA RECUPERAÇÃO JUDICIAL}

Se o impedimento ao direito de voto é visto com reserva no direito societário, com maior razão deve ser tido como excepcional em matéria concursal, sobretudo no âmbito da deliberação acerca de plano de recuperação judicial.

Na deliberação societária, a vontade social formada por meio do processo deliberativo será imputada à sociedade e é sobre ela que se refletirá. Cada um dos sócios, portanto, somente sofre os efeitos da deliberação de forma mediata. Já na deliberação sobre o plano de recuperação judicial, diversamente, apenas deliberam credores que terão as condições de seu direito de crédito alteradas (LRF, art. $45, \S^{\circ}$ ). Há, assim, uma intervenção imediata na

213 ERASMO V. A. E N. FrAnÇA, Conflito de Interesses nas Assembléias de S/A, cit., pp. 75-81.

214 Na decisão do chamado "Caso Tim" (CVM, Processo Administrativo Sancionador RJ TA 2001/4977, j. em 1912.2001), adotou-se o entendimento de que o conflito seria formal e de que o acionista controlador não poderia votar em assembleia que deliberasse acerca de contrato de uso de marca a ser celebrado com sua controladora.

215 No "Caso Previ" (CVM, Processo Administrativo Sancionador RJ TA 2002/1153, j. em 06.11.2002), adotou-se o entendimento de que o acionista não estava impedido de votar em assembleia a respeito de contrato a ser celebrado com empresa de que também é sócio.

216 No chamado “Caso Tractebel” (CVM, Processo Administrativo RJ 2009/13179, j. em 09.09.2010). 
esfera jurídica de cada credor, que justifica, ao menos a princípio, que o impedimento do direito de voto adote tons de ainda maior excepcionalidade.

O impedimento de voto, ademais, representa uma presunção absoluta de falta de isenção de um determinado participante do conclave e não permite a análise de situações concretas peculiares que podem afastar essa presunção. No direito concursal, porém, a análise da situação concreta é imprescindível, pois a presunção de falta de isenção pode ser infundada. Tome-se, como exemplo, o impedimento de voto imposto ao conselheiro fiscal de sociedade controlada pelo devedor. A lei parte da presunção de que o conselheiro fiscal está comprometido com o devedor e de que o conselheiro não terá isenção para participar do conclave junto aos demais credores. Mas imagine-se, por exemplo, que o conselheiro fiscal seja representante dos acionistas minoritários da sociedade controlada e que se tenha tornado credor da companhia devedora em razão de ter sido agredido por representantes do devedor no exercício de sua função fiscalizatória. Com a análise desses dados, seria possível considerar que o conselheiro fiscal deveria ser tratado de forma diversa de outro credor extracontratual? E o que dizer de um empregado de uma sociedade controlada pelo devedor, que seja credor de verbas trabalhistas por exposição a ambiente insalubre e que se torna representante dos empregados no conselho de administração (LSA, art. 140, par. ún.)? Os exemplos poderiam ser múltiplos, e é justamente nessa diversidade de hipóteses que reside a fragilidade da solução a priori fornecida pelo impedimento de voto. Perde-se a possibilidade de consideração de peculiaridades do caso concreto.

Apenas a título de menção, e sem desconsiderar as especificidades de cada direito concursal, nota-se que, em outros países, não é frequente a previsão de hipóteses de impedimento de voto para a deliberação no âmbito de institutos análogos à recuperação judicial - o que, em parte, se relaciona à possibilidade de formação de classes homogêneas de credores nesses países. ${ }^{217}$ No direito norte-americano, não há nenhuma hipótese de impedimento de voto para a aprovação de um reorganization plan. Tampouco no direito alemão para a aprovação do Insolvenzplan. A Itália é o país com hipóteses mais abrangentes de impedimento de voto. Na deliberação acerca do concordato preventivo, há

217 Assim, afirma MASSIMO FABIANI em relação ao direito italiano: "Il creditore non deve essere per forza escluso dal diritto di voto, ma deve essere collocato nella classe appropriata e se ciò non accade, allora, il voto è un voto invalido. Questa conclusione mi pare coerente com la teoria che vorrebbe di strettissima applicaziona la normativa sul divieto di voto" ("Brevi riflessioni su omogeneità degli interessi ed obbligatorietà delle classi nei concordati”, cit., p. 441). 
impedimento de voto pelo cônjuge do devedor, por seus parentes até o quarto grau e pelos cessionários de créditos de sua titularidade, cuja cessão tenha ocorrido menos de um ano antes da apresentação da proposta de concordato (Legge Fallimentare, art. 177). ${ }^{218} \mathrm{Na}$ deliberação acerca do concordato fallimentare, por sua vez, há impedimento de voto para as mesmas pessoas anteriormente mencionadas, mas também está impedida de votar a sociedade controladora, ou sujeita a controle comum, e os cessionários de crédito que não sejam instituições bancárias (Legge Fallimentare, art. 127). ${ }^{219}$

É possível concluir, portanto, que o impedimento de voto, por suas consequências graves, é utilizado de forma excepcional pelo direito societário. Com maior razão, então, deve ser utilizado com reserva no direito concursal, com possível restrição a casos que impliquem flagrante risco à integridade do procedimento.

\section{3. $\quad$ APLICAÇÃo ANALÓGICA DE REGRAS SOCIETÁRIAS}

Nas sociedades limitadas, não pode o sócio votar em matéria que lhe diga respeito diretamente (CC, art. 1074, $\left.\$ 2^{\circ}\right)$. Nas sociedades por ações, há, segundo alguns, impedimento de voto nas deliberações que possam beneficiar o acionista de modo particular, ou em que tenha interesse conflitante com a companhia (LSA, art. 115, $\S 1^{\circ}$ ). O denominador comum dessas hipóteses não é uma relação entre o sócio e a sociedade, mas entre uma determinada deliberação e o interesse do sócio (relação de ordem predominantemente objetiva).

Não há regra semelhante na Lei de Recuperação e Falência, nem tampouco no Código de Processo Civil, a ela aplicável subsidiariamente (LRF, art. 189). Se é possível extrair um denominador comum das hipóteses de impedimento de voto previstas no artigo 43 da LRF, é a ligação ou a proximidade de um dado credor com o devedor (relação de ordem

218 Leg. Fall., art. 177: "[...] Sono esclusi dal voto e dal computo delle maggioranze il coniuge del debitore, i suoi parenti e affini fino al quarto grado, i cessionari o aggiudicatari dei loro crediti da meno di un anno prima della proposta di concordato."

219 Leg. Fall., art. 127: "[...] Sono esclusi dal voto e dal computo delle maggioranze il coniuge del debitore, i suoi parenti ed affini fino al quarto grado e coloro che sono diventati cessionari o aggiudicatari dei crediti di dette persone da meno di un anno prima della dichiarazione di fallimento. La stessa disciplina si applica ai crediti delle società controllanti o controllate o sottoposte a comune controllo.I trasferimenti di crediti avvenuti dopo la dichiarazione di fallimento non attribuiscono diritto di voto, salvo che siano effettuati a favore di banche o altri intermediari finanziari." 
predominantemente subjetiva) que motiva a presunção absoluta de que o credor não terá neutralidade para votar.

Em outras palavras, enquanto a Lei de Recuperação e Falência tem por princípio inspirador predominante a concepção de que certas pessoas não podem votar, o direito societário proíbe o voto do sócio em relação a certas deliberações. Apesar de já se ter apontado para a inconveniência de hipóteses de impedimento de voto no âmbito da deliberação acerca do plano de recuperação judicial, não se pode negar que há divergência entre os campos primários de regulação. É possível indagar, portanto, acerca da existência de eventual lacuna, a ser integrada por meio de analogia.

Tome-se como exemplo a deliberação acerca de plano de recuperação que preveja a alienação de unidade produtiva a determinado credor. Pode-se questionar se seria possível aplicar por analogia a hipótese de impedimento de voto da sociedade por ações, da sociedade limitada, ou mesmo um princípio de vedação ao julgamento em causa própria que possa ser tido como ratio dessas normas. A questão vem sendo objeto de debate recente na Alemanha, e já há mais tempo também na Itália.

Em monografia sobre o assunto, Carsten Oelrichs questiona a possibilidade de aplicação analógica das hipóteses de impedimento de voto constantes do direito societário e do direito dos condomínios edilícios ao procedimento concursal. ${ }^{220}$ Tendo em vista o direito alemão, Oelrichs considera que as situações de impedimento de voto no direito societário e no direito condominial podem ser sintetizadas na proibição de negócio consigo próprio e na proibição de atuar como juiz em causa própria - regras, que, em verdade, se complementam. $^{221}$ As regras societárias e condominiais seriam a expressão de um princípio jurídico geral, extensível à situação de comunhão forçada, o que justificaria sua aplicação também ao procedimento concursal. ${ }^{222}$

O autor analisa, então, situações em que o credor não poderia participar de deliberações na assembleia de credores. ${ }^{223}$ Sob a rubrica da proibição de celebrar negócios consigo próprio,

220 CARSTEN P. OELRICHS, Gläubigermitwirkung und Stimmverbote im neuen Insolvenzverfahren, Köln/Berlin/Bonn/München, Carl Heymann, 1999.

$221 \quad$ Id., p. 102.

$222 \quad$ Id., p. 104.

$223 \quad$ Id., pp. 105-110. 
considera que o credor envolvido não poderá votar a respeito de um contrato a ser celebrado entre ele e a massa (na Alemanha, a matéria pode ser submetida à deliberação dos credores), nem a respeito de decisão da massa de mover ou de encerrar um processo em face do próprio credor. Já entre as hipóteses de proibição de julgar em causa própria, o autor destaca a proibição de um credor que integre o comitê de credores votar a respeito de sua destituição. Percebe-se, com isso, que o âmbito de aplicação das hipóteses de impedimento de voto propostas por Oelrichs é bastante restrito.

Deve-se salientar, ademais, uma importante redução teleológica proposta pelo autor para a analogia com o direito societário ou condominial. O impedimento de voto não se justifica quando todos os envolvidos em um processo deliberativo sejam atingidos pelo efeito da deliberação, ou seja, nas situações em que, necessariamente, todos serão juízes em causa própria. O impedimento de voto nessa situação não contribuiria para um processo íntegro de formação da vontade coletiva, mas apenas para a incapacidade deliberativa. ${ }^{224} \mathrm{O}$ caso mais relevante em que isso ocorre é na deliberação acerca de um plano de insolvência (Insolvenzplan). Como todos os credores terão suas posições de direito material atingidas, não seria possível excluir o direito de voto de nenhum credor. ${ }^{225}$ A doutrina tem esse ponto como pacífico mesmo que o plano afete um credor de forma diversa em relação aos demais credores. $^{226}$

O posicionamento de Oelrichs foi seguido por diversos doutrinadores ${ }^{227}$ e adotado em decisões judiciais, ${ }^{228}$ mas foi também alvo de críticas. Burkhard Grell considera que não existem lacunas no direito concursal alemão, pois a correção do processo de formação volitiva já seria assegurada pelo $\$ 78$ da InsO, que permite a revogação das deliberações

\footnotetext{
$224 \quad I d .$, p. 110.

$225 \quad$ Id., p. 110.

226 WilHELM UHLENBRUCK, in WiLhELM UhLENBRUCK (org.), Insolvenzordnung, 12 a ed., München, Franz Vahlen, 2003, §77, Rn. 6, p. 1273.

227 JAN GEORG BERNSEN, ROLF BERNSEN, "Stimmrechte und -verbote in der Gläubigerversammlung", in Michael Dahl, Hans-Gerd H. JaUCH, Christian Wolf (org.), Sanierung und Insolvenz - Festschrift für Klaus Hubert Görg zum 70. Geburtstag, München, C. H. Beck, 2010, pp. 27-42; WILHELM UHLENBRUCK, in WILHELM UHLENBRUCK (org.), Insolvenzordnung, cit., §77, Rn. 4-8, pp. 1272-1275,; ULRICH EHRICKE, in HANS-PETER KIRCHHOF (et al.) (org.), Münchener Kommentar zur Insolvenzordnung, Bd. 1, München, C. H. Beck, 2001, §77, Rn. 35-38, pp. 1679-1680.

228 AG Kaiserslautern, IN 423/03, j. 17.10.2005, in NZI, n. 1, 2006, pp. 46-47 (afirmando que o credor pode perseguir o próprio interesse nas deliberações, mas que, se o objeto da deliberação tangenciar o credor além do seu interesse pessoal ordinário, deve ele ser excluído da deliberação em aplicação analógica dos $\S \S$ 181 BGB e 34 BGB, que tratam, respectivamente, da proibição de o mandatário celebrar contrato consigo próprio e da exclusão de voto nas associações); AG Duisburg, Beschl. v. 08.10.2007 - 62 IN 32/07, in ZIP, n. 51/52, 2007, pp. 2429-2433.
} 
contrárias ao interesse comum dos credores. ${ }^{229}$ Ademais, aponta para o fato de que a impedimento de voto leva à formação de maiorias acidentais, com a dissociação entre responsabilidade pela tomada de decisão e sujeição aos efeitos econômicos dela decorrentes. ${ }^{230}$ Há quem considere, ainda, que a celeridade exigida em procedimentos concursais não seria compatível com o constante julgamento de alegações de que um credor estaria impedido de votar. ${ }^{231}$

Percebe-se, em suma, que no direito alemão há polêmica acerca da possibilidade de aplicação analógica de hipóteses de impedimento de voto ao procedimento concursal, mas há consenso quanto à impossibilidade de impedir o voto de um credor que terá seu direito de crédito alterado por um plano de insolvência.

Na Itália, a questão foi tratada por Roberto Sacchi. Inicialmente, o autor não abordou a possibilidade de aplicação analógica de regras societárias aos procedimentos concordatários, mas, antes, a possibilidade de extensão por analogia de hipóteses já previstas no direito concursal italiano, a exemplo da exclusão de parentes do devedor. ${ }^{232}$ Para o autor, nas hipóteses em que houvesse contraposição extremamente grave entre os interesses pessoais de um credor e o interesse dos credores enquanto tais, ou quando um credor se encontrasse em uma situação em que tivesse um interesse enquanto terceiro, o credor deveria sofrer exclusão do direito de voto. ${ }^{233}$ Entretanto, em estudo mais recente, entende que a melhor forma de lidar com a heterogeneidade grave de interesses entre os credores é por meio do classeamento, restringindo a possibilidade de impedimento de voto às hipóteses de credores que tenham recebido promessa de contraprestação pecuniária ou de vantagens econômicas. ${ }^{234}$

229 BURKHARD GRELL, "Stimmverbote im Insolvenzrecht", ("Stimmverbote im Insolvenzrecht", in NZI, vol. 2, 2006, pp. 77-81, p. 78 .

$230 \quad I d .$, p. 79.

231 STEFAN SMID, "[Rezenzion] Carsten Pay Oelrichs: Gläubigermitwirkung und Stimmverbote im neuen Insolvenzverfahren", in ZZP, vol. 114, 2001, pp. 105-109, p. 108. no mesmo sentido, JOACHIN GOEBEL, "Gläubigerobstruktion, Gläubigerstimmrecht und Beschlusskontrolle im Insolvenzverfahren über Unternehmen - Eine Untersuchung zu insolvenzrechtlichen Stimmverbote und zur Inhaltskontrolle nach §78 InsO", cit., p. 623.

232 ROBERTO SACCHI, Il principio di maggioranza nel concordato e nell'amministrazione controllata, cit., p. 438.

$233 \quad I d .$, p. 436.

234 ROBERTO SACCHI, "Concordato preventivo, conflitti di interessi fra creditori e sindicato dell'autorità giudiziaria", in Il Fallimento, n. 1, 2009, pp. 30-36, p. 33 (caso não se adote a solução de esterilização do voto, o autor entende que se deve, ao menos, situar os credores em situação de conflito de interesses em uma classe apartada). 
Tendo em vista o procedimento de deliberação sobre o plano de recuperação judicial, não há fundamento para pretender a aplicação analógica de regras societárias de impedimento de voto que tenham por fundamento a proibição do julgamento em causa própria ou que proíbam o voto de sócios que sejam diretamente atingidos pela deliberação.

Na deliberação sobre o plano de recuperação judicial, somente têm direito a voto aqueles credores que sofrerão alteração a condições de seu crédito (LRF, art. $45, \S 3^{\circ}$ ). Todos os credores votantes, portanto, são diretamente afetados pela deliberação e devem poder exprimir vontade a respeito. Se todos os credores são juízes em causa própria, todos devem poder votar. ${ }^{235}$

Já quanto à possibilidade de que o plano preveja a celebração de negócio jurídico com um dos credores, há de se ter em conta que essa não é hipótese de negócio consigo próprio. $\mathrm{O}$ plano de recuperação judicial é proposto pelo devedor e será por ele executado. Se o plano prevê a celebração de um negócio jurídico com o credor, o credor apenas consente com a celebração do negócio, mas não determina seu conteúdo. Assim, se, mesmo em âmbito societário, grande parte da doutrina afirma que o sócio pode determinar o conteúdo da vontade da sociedade e, ao mesmo tempo, atuar como contraparte em uma contratação, com maior razão poderá atuar como contraparte e votar para apenas dar consentimento a um negócio jurídico proposto no plano pelo devedor.

\section{4.}

\section{SITUAÇÕES NÃO CONTEMPLADAS EXPRESSAMENTE PELA LEI}

A Lei de Recuperação e Falência impede o voto de pessoas direta ou indiretamente relacionadas ao devedor (LRF, art. 43). Como fundamento para essa regra, pode-se vislumbrar, de um lado, a presunção de que tais pessoas não terão uma mínima isenção para decidirem acerca do plano de recuperação judicial, pois serão pautadas por uma

\footnotetext{
235 É o que, em síntese, afirmou LUIZ G. P. DE B. LEÃES acerca da possibilidade de aplicação analógica do art. 115 da LSA à assembleia geral de credores: "a assembléia geral de credores é, por natureza, muito diferente da assembléia geral de acionistas, não existindo nela a distinção acima referida, na medida em que é absolutamente natural que nela haja sempre conflito formal entre as partes e a coletividade, em face das posições contrastantes entre os diversos credores e a devedora. Tal conflito formal não impede, porém, que os credores votem no conclave, conforme previsto no diploma falimentar" (parecer não publicado, transcrito na Declaração de Voto de n. 8016, de lavra do DES. ROMEU RICUPERO, no âmbito do acórdão TJSP, AI n. 460.339-4/7-00, Câm. Esp. Fal. Rec. Jud. de Dir. Priv., REL. DES. LiNO MACHADO, v.u., j. 28.02.2007, DJ 09.03.2007).
} 
relação de ordem sentimental com o devedor - é o caso de parentes; ou, de outro lado, a presunção de que o credor não poderá participar da deliberação porque tem especial interesse na continuidade da empresa - por ser sócio do devedor, por exemplo - e aceitaria um sacrifício que não aceitaria se, como os demais credores, não desfrutasse dessa vantagem.

À luz dessas considerações, é necessário analisar hipóteses não expressamente previstas no artigo 43 da LRF, mas que eventualmente podem ser entendidas como hipóteses de impedimento de voto. Há três situações dignas de especial consideração, sem prejuízo de outras possíveis: (i) impedimento de voto imposto a todos os credores integrantes de uma classe; (ii) impedimento de voto a credores garantidos por alienação fiduciária de participações societárias da sociedade devedora; e (iii) titulares de créditos cedidos por pessoas impedidas de votar.

\subsubsection{IMPEDIMENTO DE VOTO IMPOSTO A TODOS OS CREDORES INTEGRANTES DE UMA CLASSE}

Uma situação não prevista pela lei diz respeito ao impedimento de voto que atinja, concomitantemente, todos os credores integrantes de uma classe. A ocorrência dessa situação não é completamente improvável, pois, sobretudo na classe dos credores com garantia real, é comum a ocorrência de classes com poucos credores.

Ciente dessa situação, um devedor poderá prever no plano de recuperação judicial alterações à condição de crédito do credor impedido. Como a Lei de Recuperação e Falência não exige que a ordem de prioridade dos créditos na falência (LRF, art. 83) seja obedecida na recuperação judicial, é possível, por exemplo, que o credor impedido com garantia real receba, sob o plano, muito menos do que os credores quirografários.

Como solução para essa situação, seria possível defender que, se todos os credores estão impedidos de votar, todos os credores readquiririam o direito de voto, pois a classe, no que toca à presunção de parcialidade, é homogênea. Não há credores presumivelmente inclinados a favorecer o devedor vinculando outros credores não impedidos. 
Entretanto, o sistema deliberativo acerca do plano de recuperação judicial exige duplas maiorias. Para a aprovação do plano, deve ser alcançada a maioria em todas as classes (LRF, art. 45), ou, para a aprovação na forma alternativa prevista, deve ser alcançada a maioria em ao menos duas classes (LRF, art. 58, $\S 1^{\circ}$, II). Percebe-se, com isso, que o voto do credor impedido confluirá para a determinação da vontade da comunhão de credores. Com base nisso, seria possível defender que o credor permaneceria impedido de votar.

Soluções mais satisfatórias não são oferecidas pelo texto legal. Considera-se, assim, que a mais adequada seja a consideração de que, se todos os credores integrantes de uma classe são impedidos de votar, todos readquirem o direito de voto. Com isso, o plano se torna, ao menos, mais legitimado.

\subsubsection{ALIENAÇÃo FIDUCIÁRIA EM GARANTIA DE PARTICIPAÇÕES SOCIETÁRIAS DA SOCIEDADE DEVEDORA}

Uma das garantias que podem ser prestadas pelos sócios de uma sociedade devedora na tomada de mútuos é a cessão fiduciária em garantia de ações ou cotas da própria sociedade. Cumpre esclarecer se credor que recebe essa garantia pode ser considerado "sócio" do devedor para os fins do artigo 43 da LRF.

Ressalte-se, inicialmente, que o credor da sociedade garantido pela alienação fiduciária de ações ou cotas dos sócios não recebe um bem da sociedade em alienação em garantia. Não é, portanto, um credor fiduciário da sociedade para os fins do artigo $49, \S 3^{\circ}$ da LRF, mas credor quirografário em relação à sociedade, sujeito aos efeitos da recuperação judicial.

A favor do impedimento de voto desse credor, pode-se comparar seu interesse na recuperação com o de demais credores.

Se o plano de recuperação judicial for rejeitado, será decretada a falência do devedor (LRF, art. 56, $\$^{\circ}$ ). Com a falência, dissolve-se a sociedade (CC, art. 1044; LSA, art. 206, II, “c”) e inicia-se o processo de liquidação. Após terem sido pagos os credores, os sócios terão direito a receber os valores patrimonais restantes; mas, enquanto durar a falência, não podem opor à massa "os valores decorrentes de direito de sócio ao recebimento de sua parcela do capital social na liquidação da sociedade" (LRF, art. $83, \S 2^{\circ}$ ). Como resultado, 
as participações societárias passam a ter valor reduzido, ou valor nenhum, e dificilmente será possível aliená-las a terceiro para obter a satisfação do crédito. Entretanto, se for aprovada a recuperação judicial, maior será a possibilidade de que as participações societárias possam ser alienadas em procedimento extrajudicial.

Sob esse ponto de vista, pode-se ponderar que o credor garantido por alienação fiduciária de ações ou cotas está interessado na valorização das participações societárias como qualquer outro sócio; e não como qualquer outro credor. Teria, pois, como os demais sócios, uma especial inclinação a aceitar - e a impor aos demais credores - um sacrifício ao crédito para evitar perda acentuada no valor das participações societárias. Como o artigo 43 da LRF impede o voto dos sócios do devedor, o credor garantido não poderia votar.

Em sentido oposto, pode-se argumentar que o artigo 43 da LRF teria campo de aplicação mais restrito. $\mathrm{O}$ artigo proíbe o voto do sócio da devedora, que, por algum motivo, se torna titular de crédito contra a própria sociedade devedora. A condição de credor, nessa circunstância, é contingente, tendo em vista sua condição principal como sócio. Na hipótese do credor da sociedade, peculiaridades o distinguem de um sócio que se torne credor. O credor fiduciário é sócio, mas não poderá exercer direito de voto nas deliberações sociais da sociedade devedora (LSA, art. 113, par. ún.). Ademais, na concessão de crédito à sociedade com garantia por meio da alienação fiduciária de ações, não é o acionista que se torna credor, mas, normalmente, um credor que, para garantia do crédito concedido à sociedade, recebe ações ou cotas em garantia - ou seja, a condição de acionista é contingente.

Em vista disso, é possível defender - ainda que se trate de questão polêmica - que o credor garantido por alienação fiduciária possa votar na deliberação sobre o plano de recuperação judicial, na condição de credor quirografário. Isso não significa, por óbvio, que não possa ocorrer abuso do direito de voto pelo privilégio do interese na recuperação (cf. item 4.1.4.3, infra). 


\subsubsection{CESSÃO DE CRÉDITO POR CREDOR IMPEDIDO DE VOTAR}

O artigo 43 da LRF impede o voto de certos credores, mas não prevê a hipótese de algum dos credores impedidos de votar ceder seu crédito a terceiro. Assim, cabe refletir sobre possíveis resultados da cessão de crédito por credor impedido a um terceiro não impedido de votar. $^{236}$

Se for possível à pessoa impedida de votar ceder seu crédito a um terceiro que terá direito de voto, fica facilitada a burla ao impedimento de voto. Bastaria ceder o voto a outra pessoa. Nessa cessão, seria grande a probabilidade de que o credor orientasse o cessionário a exercer o direito de voto de maneira pré-acordada.

A jurisprudência paulista enfrentou a questão. No âmbito da recuperação judicial da VarigLog S.A., titulares de créditos impedidos de votar por coligação societária com a sociedade devedora cederam seus direitos de crédito a terceiro que, sem ter relação societária com a devedora, pretendeu ver reconhecido seu direito a voto na assembleia geral que deliberaria acerca de plano de recuperação judicial. O Tribunal de Justiça de São Paulo manteve decisão de primeiro grau, adotando suas razões de decidir: "se é certo que o direito de voto decorre do crédito, certo também é que tal acessório há de seguir o destino do principal, ou seja, se o crédito não dá direito a voto, porque enquadrado na exceção do artigo 43 da Lei n. 11.101/05, igualmente, o cessionário não deterá o poder de voto. Raciocínio em contrário, a meu ver, importaria em chancelar manobra para burlar o poder de voto em detrimento dos demais credores [...]". ${ }^{237}$

Como será exposto adiante (item 4.1.3, infra), não se compartilha do entendimento de que o direito de voto seja um acessório do direito de crédito. $\mathrm{O}$ direito de voto não segue o destino do crédito por ser direito acessório ao crédito. Segue o seu destino porque o cessionário substitui processualmente o credor original e assume sua posição jurídica processual já sujeito aos mesmos ônus e restrições antes impostos ao credor originário. Sob esse raciocínio, caso ocorra cessão de crédito no âmbito do processo de recuperação

\footnotetext{
236 A possibilidade jurídica de cessão de créditos no curso da recuperação judicial será objeto de análise no item 4.1.3, infra.

237 TJSP, AI n. 994.09.287683-7, Câm. Res. Fal. Rec., REL. DES. LiNO MACHADO, j. 01.06.2010, DJ 01.07.2010.
} 
judicial, o credor cessionário fica sujeito às mesmas restrições antes impostas ao credor originário. 


\section{ABUSO DO DIREITO DE VOTO PELO CREDOR: AFERIÇÃO E CASUÍSTICA}

O abuso do direito de voto pode ocorrer de formas muito diversas. Contudo, é possível sistematizá-las, ${ }^{238}$ distinguindo duas hipóteses principais de abuso do direito de voto: a primeira, denominada abuso positivo de direito de voto, é caracterizada por uma conduta ativa de persecução de interesse estranho à comunhão; a segunda, denominada abuso negativo do direito de voto, é caracterizada pela adoção, por um credor, de comportamento obstrutivo prejudicial à comunhão de credores e sem fundamento legítimo. Convém analisá-las separadamente.

\subsection{ABUSO POSITIVO DO DIREITO DE VOTO}

O abuso positivo do direito de voto pelo credor caracteriza-se pelo exercício do direito de voto para a persecução de interesse estranho à comunhão. A designação "abuso positivo" se relaciona à circunstância de que o credor se vale do direito de voto para obter vantagem $\operatorname{particular}^{239}$ ou para impor aos demais credores deliberação que lhes seja prejudicial. Reprimir esses comportamentos é preocupação comungada por outros países.

No direito norte-americano,o artigo 1126(e) do Bankruptcy Code determina que, a pedido de uma parte interessada, a corte pode anular (designate) o voto de qualquer parte cuja aceitação ou rejeição ao plano não tenha sido de boa-fé, ou não tenha sido obtida ou solicitada de boa-fé. ${ }^{240}$

\footnotetext{
238 A classificação aqui adotada segue a classificação proposta por MARCELO V. VON ADAMEK para o abuso de minoria (Abuso de Minoria em Direito Societário (Abuso das Posições Subjetivas Minoritárias), cit., p. 155).

239 "Vantagem particular" e "benefício particular" são expressões referidas no corpo do texto apenas com o sentido de benefícios obtidos por um determinado credor não decorrentes de sua condição de credor. Não há, nesse sentido, nenhuma associação com o conceito específico de "benefício particular" adotado na Lei das Sociedades por Ações (sobre o assunto, cf. ERASmo V. A. E N. FranÇA, "O Conceito de 'Benefício Particular' e o Parecer de Orientação 34 da CVM", cit.).

$240 \mathrm{BC}$, art. 1126(e): "On request of a party in interest, and after notice and a hearing, the court may designate any entity whose acceptance or rejection of such plan was not in good faith, or was not solicited or procured in good faith or in accordance with the provisions of this title."
} 
Ao interpretar esse dispositivo, a doutrina aponta para o seu fundamento ético. Por mais que os credores possam perseguir seus próprios interesses e não se exija dos credores que sejam "nem santos, nem pecadores", ${ }^{241}$ seria injusto vincular os demais membros de uma classe pelo voto de um credor proferido em conflito de interesses. ${ }^{242}$

As cortes norte-americanas não consideram que o direito de voto do credor seja um poder funcional, tampouco exigem que seja exercido de forma altruísta. Afirma-se que o Bankruptcy Code não requer que o credor aja de forma desinteressada, e espera-se de todo credor que ele exerça seu direito de voto em linha com sua percepção de seu próprio interesse. ${ }^{243}$ Assim, em geral, se o credor apresenta um motivo adequado para o exercício do voto, as cortes presumem que o credor julgou a questão de acordo com seu interesse negocial. ${ }^{244}$ Além disso, reconhece-se que o exercício do direito de voto pode decorrer de uma infinidade de motivos, dentre os quais, por exemplo, a possibilidade de um fornecedor celebrar novos negócios com o devedor. Esse não seria, contudo, um motivo que levaria o voto a ser anulado por ter sido expresso de má-fé. O credor, ademais, pode atuar de forma egoísta e buscar aumentar o valor que receberá sob o plano, pois "[a] mera busca de um ganho econômico não é, por si, indicativa de má-fé, conquanto o interesse sendo perseguido seja o intesse do credor enquanto credor, e não o interesse do credor em outra condição". 245

Para a jurisprudência, a má-fé fica caracterizada pela persecução de um interesse ou motivo ulterior, não relacionado à posição de credor. Para distinguir a atuação egoísta da atuação pautada por motivo ulterior, a jurisprudência traça alguns parâmetros. Em $1945,{ }^{246}$ a Suprema Corte dos Estados Unidos, valendo-se da exposição de motivos do Bankruptcy Act, considerou como vedada a utilização de táticas obstrutivas por credores que busquem

\footnotetext{
241 Charles J. TABB, The Law of Bankruptcy, cit., $\$ 11.21$, p. 1127: "While voters thus need not be saints, they cannot be sinners either"

242 "The assumption implicit in the whole scheme of classifying "substantial similiar" claim together, $\S 1122$ (a), and then voting by classes, is that the members of a class will make voting decisions on plans principally on the merits of the plan as it relates to their class. If that assumption is belied, bad faith might be found. Otherwise, it would be unfair to bind the other members of the class to the class vote that is tainted by a voter with mixed motives or a conflict of interest." (CHARLES J. TABB, The Law of Bankruptcy, cit., §11.21, p. 1127).

$243 \quad$ In re Federal Support Co., 859 F.2d 19 (1988).

$244 \quad$ In re Landing, 157 B.R. 791 (1993), p. 808.

$245 \quad$ Id.

246 Sob a vigência, portanto, do Bankruptcy Act de 1933, cuja Section 203 tinha o mesmo teor.
} 
extrair vantagens indevidas para a sua cooperação. ${ }^{247}$ Em decisões posteriores, considerouse que, entre os motivos ulteriores que não poderiam motivar a atuação do credor, estavam "a pura intenção de prejudicar, extorquir, ou destruir um concorrente para favorecer um concorrente". ${ }^{248}$ Também poderia constituir má-fé a atitude de um credor cujo objetivo egoísta seja o de obstruir um plano justo e viável com a esperança de que alguém lhe pague valor superior à sua equivalente porção dos bens da massa. ${ }^{249}$

Na Alemanha, não há previsão expressa a respeito do abuso do direito de voto pelo credor. Entretanto, há duas regras que exercem, funcionalmente, papel semelhante, ao situar o interesse comum dos credores como limite para o exercício do direito de voto. O primeiro dispositivo determina que as deliberações da asembleia de credores podem ser anuladas se contrariarem o interesse comum dos credores (InsO, §78); e o segundo veda a homologação de planos que tenham sido aprovados de forma irregular, sobretudo por meio do favorecimento de uma parte envolvida (InsO, §250).

A primeira regra, que diz respeito à anulação da deliberação que contrarie o interesse comum dos credores (InsO, §78), é considerada uma expressão da vedação ao comportamento desleal pelo credor. ${ }^{250}$ Contudo, tal dispositivo não se aplica às deliberações dos credores acerca de plano de insolvência, mas somente às deliberações ordinárias da assembleia de credores que não impliquem alteração da posição subjetiva dos credores. $^{251}$

\footnotetext{
247 "Its purpose [Section 203] was to prevent creditors from participating who, 'by the use of obstructive tactics and hold-up techniques, extract for themselves undue advantages from the other stockholders who are cooperating.' Bad faith was to be attributed to claimants who opposed a plan for a time until they were 'bought off;' those who 'refused to vote in favor of a plan unless given some particular preferential advantage." Young v. Higbee Co., 324 U.S. 204 (1945), p. 212.

248 "pure malice, 'strikes', blackmail, and the [destruction of an entity] in order to advance the interests of a competing business." In re Federal Support Co., 859 F.2d 17, p. 19.

$249 \quad$ In re Landau Boat Co., 8 Bankr. 432 (1981), p. 434.

250 Assim, afirma DiRK SCHULZ que "De acordo com o $\$ 78$ InsO, o juízo falimentar pode anular uma deliberação desleal [treuwidrig], à medida que "contrarie o interesse comum dos credores" (Treuepflichten der Insolvenzgläubiger, cit., p. 160: "Nach $\$ 78$ InsO besteht die Möglichkeit, dass das Insolvenzgericht den treuwidrig gefassten Beschluss aufhebt, soweit er den 'gemeinsamen Interessen der Insolvenzgläubiger' widerspricht")

251 CARSTEN P. OELRICHS, Gläubigermitwirkung und Stimmverbote im neuen Insolvenzverfahren, cit., p. 57: “Anwendung findet $\$ 78$ InsO nur bei 'gewöhnlichen Beschlüssen’ der Gläubigerversammlung, nicht bei der Beschlussfassung über einen Insolvenzplan. Hier ist ein spezielles gerichtliches Prüfungsverfahren durch das Insolvenzgericht vorgeschaltet [...], so dass es eines Aufhebungsantrags nicht bedarf".
} 
Sob a rubrica do "interesse comum" dos credores, a doutrina alemã indica que deve ser entendido o interesse na melhor satisfação possível do crédito. ${ }^{252}$ São consideradas como contrárias a esse interesse as decisões que beneficiam o devedor ou um terceiro, ${ }^{253}$ ou um determinado credor, ${ }^{254}$ sem que a massa se beneficie. Entre as decisões confiadas aos credores no sistema concursal alemão, uma da mais relevantes diz respeito à paralisação das atividades da empresa devedora (InsO, §157). Como a assembleia de credores é composta por credores garantidos e quirografários, a doutrina acentua o risco de que os credores privilegiados tenham maior interesse em buscar a paralisação das atividades para que corram menor risco de verem dissipado o patrimônio com o qual serão satisfeitos. ${ }^{255}$ Diante da demonstração de que a decisão de paralisação das atividades tende a promover uma diminuição do volume da massa, o magistrado pode anular a decisão tomada com o voto da maioria, desde que a violação seja evidente. ${ }^{256}$

Proíbe-se, ademais, a homologação de planos de insolvência aprovados de forma irregular, sobretudo por meio do favorecimento de uma parte envolvida (InsO, §250(2)). ${ }^{257}$ Segundo a exposição de motivos da lei concursal alemã, uma forma típica de irregularidade é a "falsificação de uma deliberação por meio da venda de votos, que depois se descobre determinante para a deliberação". ${ }^{258}$ Em decisão de 2005, o Superior Tribunal Alemão (BGH) manifestou-se a propósito da questão, afirmando que a venda de voto pelo credor 252 CARSTEN P. OELRICHS, Gläubigermitwirkung und Stimmverbote im neuen Insolvenzverfahren, cit.,
p. 56.
253 gemeinsamen Interesses nach §78 InsO”, cit., p. 476.

254 KLAUS G. GÖRG, "Gerichtliche Korrektur von Fehlentscheidungen der Gläubiger im Insolvenzverfahren”, in DZWIR, n. 9, 2000, pp. 364-367, p. 365.

255 GERHARD PAPE, “Aufhebung von Beschlüssen der Gläubigerversammlung und Beurteilung des gemeinsamen Interesses nach §78 InsO”, in ZInsO, n. 9, 2000, pp. 469-478, p. 472.

256 GERHARD PAPE, "Aufhebung von Beschlüssen der Gläubigerversammlung und Beurteilung des gemeinsamen Interesses nach $§ 78$ InsO”, cit., p. 476; KLAUS G. GÖRG, "Gerichtliche Korrektur von Fehlentscheidungen der Gläubiger im Insolvenzverfahren”, cit., p. 366; e JOACHIN GOEBEL, "Gläubigerobstruktion, Gläubigerstimmrecht und Beschlusskontrolle im Insolvenzverfahren über Unternehmen - Eine Untersuchung zu insolvenzrechtlichen Stimmverbote und zur Inhaltskontrolle nach $\$ 78$ InsO”, in KTS, n. 4, 2002, pp. 615-635 (diferenciando, contudo, a necessidade de prova de acordo com o nível de adesão dos credores à decisão). Na jurisprudência, o Tribunal Superior Alemão (BGH) considerou que a anulação da deliberação conflitante com o interesse comum dos credores (com base no $§ 78$ da InsO) depende da demonstração de que haveria alternativa realizável que exigisse menor sacrifício dos credores (BGH, IX ZB 263/08, j. 10.12.2009).

257 InsO, §250 (2): "Verstoß gegen Verfahrensvorschriften: Die Bestätigung ist von Amts wegen zu versagen, (...) 2. wenn die Annahme des Plans unlauter, insbesondere durch Begünstigung eines Beteiligten, herbeigeführt worden ist."

258 DEUSTSCHER BUNDESTAG, Gesetzentwurf der Bundesregierung: Entwurf einer Insolvenzordnung (InsO), cit., p. 211. 
ao devedor ou a terceiros, seja ou não conhecida pelos demais credores, leva à nulidade do direito de voto exercido, e o plano aprovado com base em voto motivado por contraprestação financeira não deve ser homologado. ${ }^{259}$ Em linha com essa orientação, também a doutrina aponta que não pode ser homologado o plano aprovado com desrespeito ao tratamento igualitário, que pode se dar por meio do pagamento para o exercício do direito de voto. ${ }^{260}$

No direito brasileiro, o abuso positivo do direito de voto não ocorre pela mera persecução da melhor satisfação sob o plano de recuperação judicial. O sistema de recuperação judicial é pautado na crença de que a lógica do mercado - devedor e credores buscando defender seus próprios interesses -, e não mais a lógica da privatização de lucros e solidarização de perdas vigente sob o Decreto-Lei n. $7.661 / 1945,{ }^{261}$ é capaz de oferecer soluções mais consentâneas com os interesses dos envolvidos.

Sujeito ao dever de lealdade, o credor está adstrito ao respeito e à consideração aos demais credores no exercício do direito de voto. Com isso, abusa do direito de voto se atua em conflito de interesses com a comunhão de interesses, como aponta a doutrina. ${ }^{262}$ Entretanto, pode-se defender que, por conta da maior amplitude do dever de lealdade, não somente relações entre cada credor e a comunhão, mas também entre os credores devem ser pautadas pelo respeito e pela consideração recíprocos. Assim, o abuso positivo do direito de voto ocorre se o credor privilegiar interesses estranhos à sua condição de credor, exercendo o voto para obter uma vantagem particular ou para impor danos à comunhão ou aos demais credores.

A constatação do abuso do direito de voto, por sua vez, pressupõe análise das circunstâncias fáticas e concretas em que o direito de voto foi exercido. Ademais, somente

\footnotetext{
259 BGH, IX ZB 153/04, j. 03.03.2005.

260 HARAld Hess, Insolvenzrecht, Bd. 2, Freiburg i.Br., C. F. Müller, 2007, §250, Rn. 13, p. 3515.

261 RUBENS REQUIão não usou a expressão, mas deu esse diagnóstico já em 1974 (“A Crise do direito Falimentar Brasileiro - Reforma da Lei de Falências", cit., pp. 203-204).

262 ERASMO V. A. E N. FrANÇA, in Comentários à Lei de Recuperação de Empresas e Falência, cit., p. 192. No mesmo sentido, NEWTON DE LUCCA, "Abuso do direito de voto do credor na assembleia geral de credores prevista nos arts. 35 a 46 da Lei 11.101/2005", in MARCELO V. VON ADAMEK (org.), Temas de Direito Societário e Empresarial Contemporâneos - Liber Amicorum Prof. Dr. Erasmo Valladão Azevedo e Novaes França, São Paulo, Malheiros, 2011, pp. 645-666, p. 653 (“É mais que evidente que o interesse individual de um ou de alguns credores pode estar em conflito com o conjunto de interesses dos demais credores $[\ldots] ")$.
} 
poderá ser considerado abusivo o voto que desrespeite de forma "excessiva" (CC, art. 187), ou manifesta, os limites a seu exercício.

Há incontáveis possibilidades de abuso positivo do direito de voto pelo credor. Cada situação concreta exige uma avaliação distinta, e não seria possível, neste trabalho, analisar todas as hipóteses em que um credor pode desrespeitar seu dever de lealdade para com a comunhão e para com os demais credores. A casuística que segue busca abranger as hipóteses mais prováveis de abuso, sem prejuízo da eventual existência de outras não contempladas aqui.

\subsubsection{EXERCíCIO DE VOTO MEDIANTE CONTRAPRESTAÇÃo}

Comete crime o acionista que negociar o voto nas deliberações de assembleia geral de sociedade anônima com o fim de obter vantagem para si ou para outrem $\left(\mathrm{CP}\right.$, art. $\left.177, \S 2^{\circ}\right)$. O Código Penal não menciona, porém, a venda de votos em assembleia geral de credores. A LRF tipifica a prática do favorecimento de credores, consistente em ato de disposição, de oneração patrimonial ou gerador de obrigação destinado a favorecer um ou mais credores em prejuízo dos demais, seja antes ou depois da sentença que conceder a recuperação judicial (LRF, art. 172). O âmbito de aplicação do crime concursal, portanto, é mais restrito que o crime de venda de voto nas deliberações de sociedade anônima; na LRF, não há menção à hipótese de negociação de voto de um credor com outros credores, mas apenas de negociação entre credor e devedor. Além disso, não há previsão acerca dos efeitos de um eventual acordo celebrado entre o credor e o devedor, ou entre o credor e outro credor ou terceiro interessado, para a manifestação de seu direito de voto. Deve-se, portanto, analisar quais os efeitos do recebimento de contraprestação sobre a validade do exercício do direito de voto e as diferentes formas de contraprestação que podem ser obtidas por um credor para o exercício do direito de voto.

\subsubsection{VENDA DE VOTO}

Em matéria acionária, a possibilidade de cessão do direito de voto independentemente da cessão de ações é tratada de forma diversa nos países anglo-saxônicos e naqueles de 
tradição continental. ${ }^{263} \mathrm{Na}$ Alemanha, por exemplo, entende-se que o direito de voto é um elemento constitutivo da titularidade de participação acionária e não pode ser transferido separadamente das ações. ${ }^{264}$ Já nos Estados Unidos, chega-se a afirmar que o acionista "é livre para fazer o que bem entender com seu direito de voto, inclusive aliená-lo ao maior ofertante". ${ }^{265}$ No Brasil, considera-se que a lei acionária segue a linha continental, e que titularidade da ação e legitimação ao voto são indissociáveis. ${ }^{266} \mathrm{O}$ tráfico de voto na sociedade anônima, entendido como o exercício de direito de voto mediante vantagem direta ou indireta para atender aos interesses de outrem, é negócio jurídico nulo e sujeito a sanção penal. ${ }^{267}$

Se há clareza quanto à questão em matéria societária, não se pode dizer o mesmo no âmbito recuperacional. Não há, na Lei de Recuperação e Falência, previsão acerca dos efeitos decorrentes de venda de voto no âmbito da assembleia geral de credores. Cabível, portanto, a indagação a respeito de seus efeitos.

No direito italiano, de forma semelhante à lei brasileira, há punição penal ao credor que negocia com o falido vantagens para exercer seu direito de voto no concordato ou nas deliberações do comitê de credores. ${ }^{268}$ Para a doutrina, o credor que exerce o direito de voto nessas condições deve ter seu voto excluído do cômputo da deliberação. ${ }^{269}$

No direito alemão, não há vedação à venda de voto. Entretanto, há a previsão de que o magistrado não poderá homologar plano de insolvência (Insolvenzplan) cuja aprovação

\footnotetext{
263 Andreas CAHn, David C. Donald, Comparative Company Law, New York, Cambridge, 2010, p. 469.

264 UwE HÜFFER, Aktiengesetz, cit., §12, Rn. 2, p. 47.

265 Hewlett v. Hewlett-Packard Co., Del. Ch. LEXIS 44 (2002), p. 11: "Shareholders are free to do whatever they want with their votes, including selling them to the highest bidder".

266 F. C. Pontes De Miranda, Tratado de Direito Privado, Tomo 50, $3^{\mathrm{a}}$ ed., Rio de Janeiro, Borsoi, 1972, § 5.323, pp. 296-298; MARCELO L. REGO, "Direito de Voto", in AlFredo LAMY FILHO, JosÉ LuIZ B. PEDREIRA (coord.), Direito das Companhias, vol. 1, Rio de Janeiro, Forense, 2009, pp. 399-401. Em sentido contrário: FÁbio K. Comparato, Calixto Salomão Filho, O Poder de Controle na Sociedade Anônima, $4^{\mathrm{a}}$ ed., Rio de Janeiro, Forense, 2005, p. 207.

267 Modesto Carvalhosa, Comentários à Lei de Sociedades Anônimas, vol. 2, cit., p. 344.

268 Leg. Fall., art. 233: "Mercato di voto: Il creditore che stipula col fallito o con altri nell'interesse del fallito vantaggi a proprio favore per dare il suo voto nel concordato o nelle deliberazioni del comitato dei creditori, è punito con la reclusione da sei mesi a tre anni e con la multa non inferiore a lire 200.000 [n.d.r. 103,00 euro]."

269 ROBERTO SACCHI, "Dai soci di minoranza ai creditori di minoranza", cit., p. 1068; AURELIO CAndian, "Vendita di voto in concordato?", in Riv. Dir. Comm., vol. 17, Parte II, 1919, pp. 84-91 (em comentário a decisão que entendeu que a promessa de vantagens comerciais ao credor caso o concordato fosse aprovado poderia ser equiparada à venda de voto).
} 
tenha sido obtida de forma irregular, sobretudo por meio do favorecimento de um participante. ${ }^{270}$ Segundo a exposição de motivos da lei concursal alemã, uma forma típica de irregularidade é a falsificação de uma deliberação por meio da venda de votos, que é posteriormente descoberta como determinante para a deliberação. ${ }^{271}$ Em decisão de 2005, o Tribunal Federal Alemão (BGH) manifestou-se a propósito da questão em obiter dictum, afirmando que a venda de voto pelo credor ao devedor ou a terceiros, seja ou não conhecida pelos demais credores, leva à nulidade do direito de voto exercido, e o plano aprovado com base em voto motivado por contraprestação financeira não deve ser homologado. ${ }^{272} \mathrm{Em}$ linha com essa orientação, também a doutrina defende que não pode ser homologado o plano aprovado mediante pagamento para o exercício do direito de voto, já que um credor será beneficiado em quebra à igualdade entre os credores. ${ }^{273}$

Ademais, também no direito norte-americano que, como se viu, é permissivo à negociação do direito de voto em matéria acionária, entendeu-se que o voto proferido mediante pagamento constitui exercício de direito de voto em desconformidade com a boa-fé. No caso Belleair v. Groves, o município Town of Belleair propusera um plano de reorganization e, para garantir a aceitação do plano por $68 \%$ dos credores detentores de títulos de dívida (bondholders), ofereceu somente a esses credores isenções fiscais caso o plano fosse aprovado. Decidiu-se, nesse caso, que a aprovação do plano deveria ser negada, pois não se pode admitir a utilização de special inducements para assegurar a aceitação do plano. $^{274}$

Apesar da ausência de previsão expressa a respeito das consequências da venda de voto por credor, é patente que, nessa situação, o credor votante obtém uma vantagem que não partilha com os demais integrantes da coletividade. Ao exercer seu direito de voto contra prestação pecuniária, o credor deixa de buscar a satisfação de seu crédito exclusivamente

$270 \quad$ InsO, $\$ 250$ (2): "Verstoß gegen Verfahrensvorschriften: Die Bestätigung ist von Amts wegen zu versagen, (...) 2. wenn die Annahme des Plans unlauter, insbesondere durch Begünstigung eines Beteiligten, herbeigeführt worden ist."

271 DeUSTSCHER BUndeSTAG, Gesetzentwurf der Bundesregierung: Entwurf einer Insolvenzordnung (InsO), cit., p. 211.

272 BGH, IX ZB 153/04, j. 03.03.2005.

273 HARALD HESS, Insolvenzrecht, §250, Rn. 13, p. 3515.

$274 \quad$ Belleair v. Groves, 132 F.2d 542 (1942), p. 543: "The court below thought that it would violate the requirement of good faith in offer and acceptance to permit bondholders, whose consent to the proposal was induced by special interests akin to those of the debtor, to bind others who dealt as creditors only. It, accordingly, held that the plan did not satisfy the requirements of the Act. We cannot say that the court erred in so doing." 
por meio do procedimento coletivo; seu voto não representa uma avaliação leal da viabilidade da empresa, pois o empobrecimento do devedor, a destruição de valor ou a pior satisfação dos credores lhe importarão menos. Ao não sacrificar seus interesses da mesma forma que os demais credores, aquele que recebe contraprestação pecuniária abusa do seu direito de voto, pois descumpre seu dever de lealdade para com os demais credores. Assim, embora seja possível a cessão de crédito (cf. item 4.1.3.2, infra), não é possível a cessão ou venda do direito de voto. ${ }^{275}$

\subsubsection{CELEBRAÇÃO DE CONTRATO PRELIMINAR ENTRE DEVEDOR E CREDOR}

Ao invés de oferecer remuneração direta para que o credor exerça o direito de voto de uma determinada maneira, é possível que o devedor ofereça contraprestação indireta, condicionada à aprovação de plano de recuperação judicial. Pense-se, por exemplo, em um banco credor que celebre com o devedor um contrato preliminar para coordenar uma emissão de debêntures caso o plano de recuperação seja aprovado. Dado seu distinto interesse na aprovação da recuperação judicial decorrente da vantagem individual a que fará jus, pode-se questionar se o credor cumpre seu dever de lealdade para com os demais credores quando vota tendo em vista a possibilidade de celebração do contrato.

A questão foi objeto de debate na Itália. Para parte da doutrina, a ratio da proibição de venda de direito de voto no concordato é a proibição de escambo do direito de voto por uma vantagem patrimonial. Na promessa de celebração de negócio jurídico pelo devedor, deve-se partir do pressuposto de que a vantagem patrimonial a ser obtida pelo credor será fruto de sua contraprestação, definida no contrato. Se o contrato não é fraudulento e há correspectividade entre as prestações, não se pode considerar que a promessa do devedor seja uma contraprestação pelo exercício do direito de voto. ${ }^{276}$ Para a outra vertente, a venda de voto é uma das hipóteses que justifica o impedimento de voto, mas não a única. $\mathrm{O}$ credor a quem são prometidas vantagens consistentes na continuidade de relacionamento

275 Nesse sentido, afirma ERASMO V. A. E N. FRANÇA que se pode "ceder o crédito (e com ele o voto), mas não é possível separar uma coisa da outra” (in FrANCISCO S. DE SOUZA Junior, ANTÔNIO SÉRGIO A. DE M. РітомBo (coord.), Comentários à Lei de Recuperação de Empresas e Falência, cit., p. 211).

276 Aurelio CANDIAN, "Vendita di voto in concordato?", cit., pp. 84-91. 
comercial age movido por interesses estranhos à sua qualidade de credor e, por conta disso, não deveria participar do conclave. ${ }^{277}$

Em linha com a perspectiva adotada neste trabalho, acredita-se que a análise de eventual abuso do direito de voto deva ser casuísta, pautada pela análise da situação concreta. Nesse contexto, a celebração de contrato preliminar entre credor e devedor não pode ser considerada suficiente para que se afirme que o credor abusa do direito de voto. Enretanto, caso seja comprovada desproporção entre as prestações no contrato a ser celebrado, a celebração de contrato pode ser equiparada à venda de voto. O voto assim exercido será abusivo.

\subsubsection{Pl PANO QUE PREVÊ CELEBRAÇÃo DE NEGÓCIO JURÍDICO COM CREDOR}

Entre os meios de recuperação judicial previstos em lei, encontram-se hipóteses em que deve ser celebrado negócio jurídico bilateral entre o devedor e um terceiro. Pense-se, exemplificativamente, no trespasse de estabelecimento do devedor (LRF, art. 50, VII) também designado, incorretamente, como unidade produtiva isolada (LRF, art. 60) ${ }^{278}$-, na alteração de controle societário (LRF, art. 50, III) ou na venda parcial de bens (LRF, art. XI). Caso o plano de recuperação preveja a celebração de um desses negócios jurídicos com determinado credor, pode-se questionar a possibilidade de que haja abuso do direito de voto quando esse for exercido para garantir a aprovação do plano.

O abuso do direito de voto, nessas condições, parece improvável. Em uma sociedade, quando os sócios deliberam acerca da celebração de contrato com um dos sócios, formam a vontade que será imputada ao ente coletivo. Há, portanto, risco de abuso do direito de voto se essa vontade for determinada por uma maioria pré-constituída que, ao mesmo tempo, atue como contraparte do negócio jurídico.

277 ROBERTO SACCHI, Il principio di maggioranza nel concordato e nell'amministrazione controllata, , pp. 465-466.

278 Para crítica à imprecisão conceitual do legislador, cf. EDUARDO S. MUNHOZ, in FRANCISCO S. DE Souza JR., Antônio S. A. DE M. PITOMbo (coord.), Comentários à Lei de Recuperação de Empresas e Falência, cit., p. 298; PAUlo Fernando C. S. DE TOLEDO, BRUnO POPPA, "UPI e Estabelecimento: uma Visão Crítica", in Paulo Fernando C. S. DE Toledo, Francisco SATIRo (coord.), Direito das Empresas em Crise: Problemas e Soluções, cit., pp. 267-294, p. 277; Jorge Lobo, PAulo Fernando C. S. DE TOLEDO, CARlos H. ABRÃo (coord.), Comentários à Lei de Recuperação de Empresas e Falência, São Paulo, Saraiva, 2005, p. 160. 
Já o plano de recuperação judicial pode ser proposto somente pelo devedor (LRF, art. 48, caput). ${ }^{279}$ É o devedor quem, autonomamente, poderá avaliar a conveniência de celebrar negócio jurídico com um dos credores. Já os credores, ao deliberarem pela aprovação ou pela rejeição do plano, irão somente consentir com a celebração de um negócio jurídico pelo devedor e por um credor. Além de o credor que celebrará o negócio jurídico não estar impedido de votar (cf. item 3.3, supra), ele não obtém, normalmente, nenhuma vantagem particular não compartilhada com os demais credores, pois o contrato proposto pelo devedor - autônomo e independente em relação aos credores - presumivelmente será equitativo.

É possível, contudo, que o plano de recuperação judicial preveja a celebração de negócio jurídico com um credor em termos particularmente desvantajosos para o devedor, como forma de cooptar o credor para que aprove o plano de recuperação judicial. Nessa situação, pode ocorrer abuso, mas será por conta da possibilidade de equiparar a vantagem injustificada a uma remuneração pelo voto. Trata-se de hipótese similar à da celebração de um contrato preliminar para a celebração de contrato não equitativo, já analisada (cf. item 4.1.1.2, supra).

\subsubsection{PERSPECTIVA de CELEBRAÇÃo de nOVOS CONTRATOS COM O DEVEDOR}

Questão diversa é a possibilidade de o credor votar movido pela perspectiva, não formalizada, de celebrar novos contratos com o devedor ou de manter uma relação contratual existente. É o caso, respectivamente, de fornecedores e de trabalhadores. Cabe questionar se seria possível afirmar que o credor que vota tendo em vista a continuidade de relações negociais com o devedor se beneficia de forma particular pela manutenção da empresa, descumprindo seu dever de lealdade para com os demais credores quando se pauta por essa circunstância para exercer o direito de voto.

Não se pode presumir que a celebração de contratos é uma vantagem em si, caso não se demonstre desequilíbrio no contrato. Além disso, é natural que os credores mantenham relações recorrentes com o devedor, e a perspectiva de continuar a mantê-las é um dos

279 Para críticas à exclusividade do devedor para a propositura de plano de recuperação judicial, cf. SheIla C. N. CEREZETTI, A Recuperação Judicial de Sociedade por Ações - O Princípio da Preservação da Empresa na Lei de Recuperação e Falência, cit., pp. 256-278. 
motivos lícitos possíveis para a decisão acerca de um plano de recuperação judicial. Assim, não abusa do direito de voto o credor que vota considerando que poderá celebrar contratos futuros com o devedor em crise.

\subsection{2. $\quad$ ABUSO DO DIREITO DE VOTO POR TRATATIVAS COM DEVEDOR}

Questão normalmente relacionada ao exercício de voto mediante remuneração, mas dela distinta, é o eventual abuso do direito de voto por credor que mantém negociações bilaterais com o devedor.

No processo de recuperação judicial, o devedor apresenta um plano ao juízo (LRF, art. 53), que resultará na concessão de recuperação judicial se não houver objeção por nenhum credor (LRF, art. 58, caput) ou na convocação de assembleia geral para deliberação, se algum dos credores apresentar objeção no prazo de trinta dias (LRF, art. 56 c/c art. 55). Em assembleia de credores, então, o plano será aprovado, rejeitado, ou modificado (LRF, art. 35, I, "a"), mas a lei não menciona a possibilidade de negociação entre o devedor e os credores antes do pedido de recuperação judicial, no curso do procedimento de recuperação judicial ou mesmo em assembleia.

Parece claro e pouco discutível que essas negociações possam ocorrer. Um dos objetivos da Lei de Recuperação e Falência era o de estimular a participação ativa dos credores. ${ }^{280}$ Entretanto, não há clareza quanto à forma como pode ser viabilizada essa negociação. $\mathrm{O}$ Comitê de Credores, órgão de instalação facultativa no curso do procedimento de recuperação judicial, não tem competência para negociar com o devedor (LRF, art. 27, I). ${ }^{281}$ Resta, então, a possibilidade de negociações diretamente entre o devedor e todos os credores (sobretudo em assembleia), ou, ainda, entre o devedor e um ou mais credores fora de assembleia. A primeira possibilidade não gera questionamentos jurídicos, pois todos os

$280 \quad$ No Parecer n. 534/2004, da Comissão de Assuntos Econômicos do Senado Federal, de relatoria do Sen. RAMEZ TEBET, em que foi apresentado substitutivo ao PL n. 71/2003, da Câmara dos Deputados, a negociação entre devedor e credores é pressuposta nesta passagem: "[n]a recuperação judicial, o art. 57 parece misturar os conceitos de deferimento do processamento da recuperação judicial e de concessão da recuperação judicial, pois prevê o início da contagem do prazo de suspensão das ações e execuções após “deferida a recuperação judicial”, quando obviamente essa suspensão - por servir às negociações que precedem a aprovação do plano pela assembléia, após a qual o juiz decide pela concessão - não faz sentido após o início dos efeitos do plano aprovado. (p. 11, grifou-se).

281 A situação é diversa nos Estados Unidos, em que os creditors' committees e equity committes negociam com o devedor, representando os credores e titulares de participação societária (CHARLES J. TABB, The Law of Bankruptcy, cit., §11.8, pp. 1066-1072) 
credores podem participar da negociação em igualdade de condições. Sua efetividade, contudo, é reduzida por conta da complexidade de estruturar negociações com uma multiplicidade de partes. Duas questões, então, se colocam. A primeira, examina se é possível a negociação direta entre devedor e um ou mais de seus credores ou se deve haver presunção de que o credor que trava negociações bilaterias com o devedor abusa de seu direito de voto quando, em decorrência das negociações, vota pela aprovação de um plano. A segunda, investiga se o credor pode se vincular ao devedor ou a outros credores para exercer o direito de voto de uma forma pré-determinada, instrumento importante para a estabilização de negociações.

\subsubsection{LICITUDE DE TRATATIVAS BILATERAIS ENTRE CREDOR E DEVEDOR}

A questão da licitude de tratativas bilaterais entre credor e devedor foi enfrentada pelo Tribunal de Justiça do Estado de São Paulo. Em decisão no âmbito da recuperação judicial da Bombril Holding S.A., entendeu-se que não havia ilegalidade na negociação bilateral entre o devedor e um de seus credores. ${ }^{282}$ Em outra oportunidade, afirmou-se que "tratativas paralelas entre credor e devedor não configuram, desde logo, abuso do direito ou fraude contra os demais credores. Aliás, tendo-se em vista os objetivos da lei de regência, curial que a reestruturação da empresa possa ser renegociada pela recuperanda também diretamente junto a cada um de seus credores". 283

Em si, o posicionamento pode ser considerado como acertado. Contudo, há de se ter cautela para que, no âmbito da negociação bilateral, um credor não seja unilateralmente beneficiado pelo devedor por meio da concessão de informações privilegiadas que, depois, possam ser utilizadas, por exemplo, para a aquisição de créditos de titularidade de outros credores. Ou seja, a negociação bilateral é lícita, mas o fornecimento de informações deve ser pautado pela igualdade entre os credores.

282 TJSP, AI n. 460.339-4/7-00, Câm. Esp. Fal. Rec. Jud. de Dir. Priv., REL. DES. LINO MACHADO, j. 28.02.2007, DJ 09.03.2007.

283 TJSP, AI n. 0136462-81.2011.8.26.0000, Câm. Res. Fal. Rec., REL. Des. Elliot AKEl, v.u., j. 18.10.2011, DJ 19.10.2011. 


\subsubsection{LICITUDE DE ACORDO PARA EXERCÍCIO DO DIREITO DE VOTO}

A vinculação entre o credor e o devedor para o exercício do direito de voto de forma prédeterminada é prática comum no direito estadunidense, no contexto dos chamados prepackaged plans, ${ }^{284}$ e foi considerada como lícita pelo TJSP. ${ }^{285}$ Aponta-se, também, no âmbito doutrinário, para a possibilidade de vinculação do exercício de voto por meio de celebração de "acordo de credores". 286

Ambas as práticas podem ser consideradas como lícitas. Se a promessa de exercício de direito de voto não for motivada por vantagens particulares e se for conferido tratamento equitativo aos credores integrantes de cada classe, não se vislumbra - por conta desse fato exclusivamente - abuso do direito de voto.

\subsubsection{CESSÃo DE CRÉDITO}

As competências da assembleia geral de credores são exercidas por meio de um sistema deliberativo estruturado na separação dos credores em classes (artigo 41 LRF). No âmbito de cada classe, os poderes decisórios, embora conferidos a todos os credores, serão exercidos efetivamente pela maioria, que vincula os integrantes dissidentes. ${ }^{287}$ Mais do que um direito econômico, o direito de crédito passa a exercer a função de instrumento de legitimação para o exercício de direitos de participação no âmbito da assembleia geral, considerada como órgão da comunhão de credores. ${ }^{288}$

Enquanto a cessão de crédito detido em face de devedor em situação econômico-financeira saudável representa apenas uma transferência de direitos econômicos, a cessão de crédito do devedor em recuperação judicial implica, ainda, uma alteração da capacidade de

\footnotetext{
284 CHARLES J. TABB, The Law of Bankruptcy, cit., §11.23, pp. 1130-1132.

285 Voto n. 8016, de lavra do DES. ROMEU RICUPERO, no âmbito do acórdão TJSP, AI n. 460.339-4/700, Câm. Esp. Fal. Rec. Jud. de Dir. Priv., ReL. Des. LINO MACHADO, v.u., j. 28.02.2007, DJ 09.03.2007.

286 Vinícius J. M. GonTIJo, "Falência e Recuperação de Empresas: Acordo de Credores na Assembleia Geral", in $R D M$, vol. 159/160, 2011, pp. 167-172.

287 Note-se, contudo, que nem sempre é necessária a obtenção de maioria em todas as classes para a aprovação de plano de recuperação judicial. Por meio do procedimento previsto no artigo 58 da LRF, é possível a aprovação do plano mesmo que não seja alcançada a maioria em uma das classes, desde que os demais requisitos exigidos sejam preenchidos.

288 ERASMO V. A. E N. FrançA, “A Assembléia-Geral de Credores na Nova Lei Falimentar”, cit., p. 8.
} 
influenciar o andamento do procedimento concursal; significa, portanto, também uma cessão de direitos políticos no âmbito da comunhão de credores.

Abre-se, com isso, a possibilidade de emprego estratégico da cessão de créditos para que se obtenha posição majoritária em cada classe, ou, ainda, entre classes. Em decorrência de cessão de crédito, grupo de credores que alcançaria a maioria por cabeça, mas não por crédito, pode conquistar a possibilidade de ditar a orientação de voto de determinada classe. Pode ser obtida posição dominante de mais de dois terços dos créditos em uma classe, o que impediria a aprovação de um plano de recuperação judicial mesmo na hipótese de cram down (por inobservância do requisito previsto no artigo $58, \S 1^{\circ}$, III da LRF).

Há de se considerar, apesar da possibilidade descrita acima, que nem sempre o credor cessionário terá motivações estratégicas para a aquisição de crédito concursal. Nem todos os credores dispõem de conhecimento ou de paciência para enfrentar um procedimento de recuperação judicial. Tampouco estão dispostos a arcar com os custos de honorários advocatícios, de custas judiciais e de enfrentar potenciais conflitos judiciais decorrentes de impugnações a seu direito de crédito. Investidores especializados podem participar do processo concursal de forma mais eficiente (por já contarem com um departamento jurídico estruturado, por exemplo). Por conta disso, se os credores originais estiverem dispostos a aceitar deságio em relação ao valor de face de seus créditos, é possível que a aquisição do crédito possa ter em vista apenas aspectos econômicos.

Cabe, portanto, analisar a conveniência de se permitirem a cessão de crédito e a decorrente cessão da prerrogativa de exercer o direito de voto pertinente ao crédito, depois de iniciado o procedimento concursal.

\subsubsection{Problemas RELACIONAdos À CESSÃo de CRÉditos CONCURSAIS E TRATAMENTO NO DIREITO ESTRANGEIRO}

Nos Estados Unidos, há grande discussão a respeito da melhor forma de regular a cessão de créditos durante o procedimento concursal. Como regra, admite-se a livre cessão de 
créditos concursais, prática designada como trading in claims. ${ }^{289}$ Como a cessão pode ocorrer por valor inferior ao valor de face do crédito e os investidores institucionais normalmente possuem mais informações acerca do devedor e de seu potencial econômico do que credores que não atuam na área, é grande a possibilidade de lucro, o que motivou a criação de fundos especializados nas décadas de 80 e 90 do século passado, pejorativamente alcunhados como "fundos abutres" (vulture funds). ${ }^{290}$ Esses fundos geralmente adquiriam créditos suficientes para o controle do resultado da deliberação em uma classe, seja para simplesmente aumentar seu poder de negociação, ou mesmo para obter um poder de veto sobre qualquer proposta de reorganização. ${ }^{291}$

Sem uma vedação estrutural à negociação de créditos nem uma restrição ao exercício do direito de voto pelos cessionários investidores, situações de manipulação estratégica passaram a ser enfrentadas pela jurisprudência. Segundo o já mencionado § 1126(e) do Bankruptcy Code, o juiz pode desconsiderar o voto de qualquer participante cuja aceitação ou rejeição não tenha sido de boa-fé, ou que não tenha sido solicitado ou obtido de boafé. ${ }^{292}$ No caso In re Allegheny International, Inc. ${ }^{293}$ discutiu-se a possibilidade de que o voto fosse desconsiderado em decorrência da aquisição estratégica de créditos. Nesse caso, após a apresentação de um plano de reorganização pelo devedor, uma empresa que não era credora antes do início do procedimento concursal adquiriu créditos e apresentou seu próprio plano de reorganização, sob o qual obteria o controle societário da sociedade devedora (pretendendo, assim, promover um takeover hostil por meio do procedimento concursal). Momentos antes da votação do plano do devedor, a empresa adquiriu novos créditos integrantes das duas classes com maior prioridade, obtendo o poder de bloquear o plano proposto pelo devedor. Diante disso, a Corte de Pennsylvania considerou que o voto foi exercido de má-fé, pois foi motivado pelo objetivo ulterior de ganhar vantagem (a aquisição de controle) à qual não teria direito na condição credor; ademais, considerou que, ao obter uma posição de veto, o cessionário neutralizou a influência de todos os demais credores, tornando impossível considerar as preferências e interesses dos demais credores,

\footnotetext{
289 CHARLES J. TABB, The Law of Bankruptcy, cit., §11.22, p. 1128.

$290 \quad$ Id., $\$ 11.22$, p. 1129.

291 ScOtT K. CHARLES, "Trading Claims in Chapter 11 Cases: Legal Issues Confronting the Postpetition Investor”, in Ann. Surv. Am. L., 1991, pp. 261-332, p. 262.

292 BC, $\S 1126(\mathrm{e})$ : “On request of a party in interest, and after notice and a hearing, the court may designate any entity whose acceptance or rejection of such plan was not in good faith, or was not solicited or procured in good faith or in accordance with the provisions of this title."

293 In re Allegheny International, Inc., 118 B.R. 282 (1990).
} 
o que seria incompatível com os objetivos do Bankruptcy Code, pautado pela ideia de solução coletiva e consensual para o estado de crise. ${ }^{294}$

De modo diverso, no caso In re Marin Town Center, entendeu-se que a aquisição de créditos necessários para a obtenção da maioria dos direitos de voto não era, por si, motivo suficiente para que o exercício dos respectivos direitos de voto fosse considerado de máfé. ${ }^{295}$ Charles J. Tabb, comentando o assunto, não oferece claras indicações sobre qual seria o critério jurisprudencial para a determinação da má-fé no exercício do direito de voto pelo credor que adquire créditos concursais. ${ }^{296}$

Parte da doutrina norte-americana defende que o mercado de créditos deve ser livre, para que nenhum credor tenha de permanecer nessa condição contra sua vontade; no máximo, devem ser impostas medidas regulatórias para aumentar a transparência das transações e garantir que os vendedores não sejam prejudicados por sua inexperiência ou falta de informação em relação ao devedor. ${ }^{297}$

Há, entretanto, uma corrente que considera que a livre-negociação de créditos gera impactos significativos sobre a operacionalidade do sistema de reorganização previsto no Chapter 11. Argumenta-se que, em um procedimento de satisfação coletiva, os credores passam a ser interdependentes, e toda a negociação que se desenvolve no âmbito do procedimento reorganizativo é baseada na cooperação e na confiança mútua, adquirida durante a negociação de um plano de reorganization. ${ }^{298}$ A livre negociação de créditos destrói esse relacionamento e limita o incentivo para que as partes o construam - pois elas já sabem que o relacionamento poderá ser desfeito a qualquer momento. ${ }^{299}$ Além disso, a

\footnotetext{
294 In re Allegheny International, Inc., 118 B.R. 282 (1990), pp. 290-291.

$295 \quad$ In re Marin Town Center, 142 B.R. 374 (1992), p. 380.

296 ChARLES J. TABB, The Law of Bankruptcy, cit., \$11.22, p. 1129.

297 Herbert P. Minkel JR., Cynthia A. BAKER, "Claims and Control in Chapter 11 Cases: a Call for Neutrality", in Cardozo L. Rev., vol. 13, 1991, pp. 35-101; ANDREW AFRICK, "Trading Claims in Chapter 11: How Much Influence Can Be Purchased in Good Faith Under Section 1126?”, in U. Pa. L. Rev., vol. 139, 1991, pp. 1393-1422; ChAIM J. Fortgang, ThOMAS M. MAYER, "Trading Claims and Taking Control of Corporations in Chapter 11", in Cardozo L. Rev., vol. 12, 1990, pp. 1-115; PAUL M. GoLDSCHMID, "More Phoenix than Vulture: the Case for Distressed Investor Presence in the Bankruptcy Reorganization Process", in Colum. Bus. L. Rev., vol. 1, 2005, pp. 191-274; ADAM J. LEVITIN, "Finding Nemo: Rediscovering the Virtues of Negotiability in the Wake of Enron", in Colum. Bus. L. Rev., 2007, pp. 83-177.

298 FrederICK TUNG, "Confirmation and Claims Trading”, in Nw. U. L. Rev., vol. 90, 1996, pp. 16841754 , p. 1707.

$299 \quad$ Id., p. 1718.
} 
presença de investidores institucionais seria em grande medida conflitante com as premissas do sistema recuperacional. As classes de credores geralmente são compostas por diversos titulares de créditos, que mantiveram relacionamento comercial prévio com o devedor e que, muitas vezes, têm a perspectiva de manter também um relaciomento futuro. ${ }^{300}$ De forma diversa, os credores profissionais adquirem créditos estrategicamente para aumentar seu potencial de negociação, podem utilizar sua estrutura jurídica para impugnar os demais créditos (ou ameaçar fazê-lo) e, geralmente, não mantinham um relacionamento comercial prévio com a empresa, nem tendem a desenvolvê-lo. ${ }^{301}$ Muito embora se reconheça que a proibição da cessão de créditos concursais seria prejudicial, ${ }^{302}$ já foram propostas tanto a sujeição de transações a escrutínio judicial como a limitação da permissão para sua realização, impondo-se restrições ao momento processual em que as cessões de crédito poderiam ser realizadas. ${ }^{303}$

A recente discussão norte-americana a respeito do tema reflete o agravamento dos problemas causados pela presença de investidores institucionais agressivos (e pouco regulados até 2008) e pela disseminação de instrumentos financeiros. Com o aumento da utilização de instrumentos derivativos nos Estados Unidos, sobretudo dos chamados credit default swaps, credores conseguiam obter a garantia de que, caso o devedor inadimplisse, receberiam, ainda assim, o valor total de seu crédito. ${ }^{304}$ Esse fato perverte a lógica

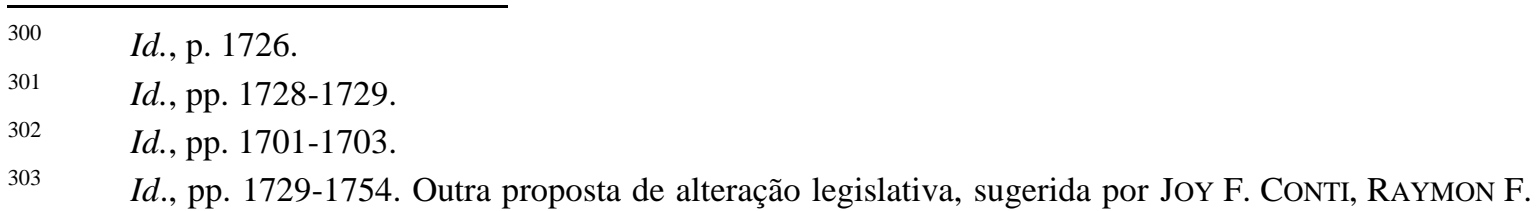
KOZLOWSKI JR. e LEONARD S. FERLEGER, consiste em subordinar as transações a escrutínio judicial, com possibilidade de sua proibição quando se constatar que o comprador tem interesse ulterior de adquirir a companhia por meio da utilização de sua posição de credor ("Claims Trafficking in Chapter $11-$ Has the Pendulum Swung Too Far?”, in Bankr. Dev. J., vol. 9, 1992, pp. 281-355, p. 315).

$304 \quad$ O funcionamento dos credit default swaps foi assim descrito: "A key OTC derivative in the financial crisis was the credit default swap (CDS), which offered the seller a little potential upside at the relatively small risk of a potentially large downside. The purchaser of a CDS transferred to the seller the default risk of an underlying debt. The debt security could be any bond or loan obligation. The CDS buyer made periodic payments to the seller during the life of the swap. In return, the seller offered protection against default or specified "credit events" such as a partial default. If a credit event such as a default occurred, the CDS seller would typically pay the buyer the face value of the debt. Credit default swaps were often compared to insurance: the seller was described as insuring against a default in the underlying asset. However, while similar to insurance, CDS escaped regulation by state insurance supervisors because they were treated as deregulated OTC [over-the-counter] derivatives. This made CDS very different from insurance in at least two important respects. First, only a person with an insurable interest can obtain an insurance policy. A car owner can insure only the car she owns - not her neighbor's. But a CDS purchaser can use it to speculate on the default of a loan the purchaser does not own. These are often called "naked credit default swaps" and can inflate potential losses and corresponding gains on the default of a loan or institution." (UNITED STATES GOVERNMENT, The Financial Crisis Inquiry Report, Washington, U.S. Government Printing Office, 2011, p. $50)$. 
concursal $^{305}$ e cria problemas de grave desalinhamento de interesses entre os credores. ${ }^{306}$ Atualmente, o que se relata é uma crescente participação de investidores institucionais com pouca tendência a cooperar, que perseguem objetivos radicalmente dissonantes ${ }^{307}$ e, muitas vezes, estão diretamente interessados na liquidação do devedor, seja por contarem com a proteção de instrumentos derivativos, ${ }^{308}$ seja por participarem do capital de companhias concorrentes, que serão beneficiadas com a exclusão do devedor do mercado. ${ }^{309}$ Há, ademais, credores interessados apenas em adquirir créditos para, depois, revendê-los a preço superior (claim flipping), sem nenhum interesse em participar de negociações, ${ }^{310}$ além de credores que adquirem créditos visando a adquirir o controle societário do devedor. $^{311}$

Pode-se afirmar, em suma, que, nos Estados Unidos, é permitida a cessão de créditos concursais, mas que, em certas ocasiões, a aquisição de créditos com o objetivo de obter poder de controle sobre uma classe pode levar à anulação do voto exercido pelo credor. Sob o plano de política legislativa, há discussão quanto à conveniência da permissão de cessão de créditos, mas, em que pese a recente discussão desencadeada pela crise financeira de 2008, ainda prevalece o entendimento de que a questão deva ser resolvida pelo aumento na divulgação de informações, possibilitando aos cedentes condições adequadas de avaliar a conveniência da cessão de crédito.

Na Alemanha, o Tribunal Federal Alemão (BGH) pronunciou-se, em 2005, acerca da legalidade de cessões de crédito. Interpretando a regra de que um plano não poderia ser

305 Segundo DOUGLAS G. BAIRD E ROBERT K. RASMUSSEN, o sistema concursal é constituído tendo por base a assunção de que os credores detêm interesses minimamente paralelos e de que, por conta disso, a minoria pode ser vinculada pela maioria (“Antibankruptcy”, in Yale L. J., vol. 119, 2010, pp. 648-699, p. $654)$.

306 "If the largest creditor in a class has hedged its risk with credit default swaps, should that same creditor have the power to upend the debtor's proposed plan?" STEPHEN J. LUBBEN, "Credit Derivatives and the Future of Chapter 11", in Am. Bankr. L. J., vol. 81, 2007, pp. 405-430, p. 407 (note-se que, apesar de o autor reconhecer o problema, não chega a defender o impedimento de voto, mas somente maior divulgação de informações pelos credores).

307 DOUGLAS G. BAIRD, ROBERT K. RASMUSSEN, “Antibankruptcy”, cit., p. 657.

$308 \quad$ Id., pp. 678-686.

309 Id., p. 686. Para uma crítica às formulações de Baird e Rasmussen, cf. ADAM J. LEVITIN, "Bankruptcy Markets: Making Sense of Claims Trading”, in Brook. J. Corp. Fin. \& Com. L., vol. 4, 2009, pp. 67-112.

$310 \quad$ RICHARD D. THOMAS, "Tipping the Scales in Chapter 11: How Distressed Debt Investors Decrease Debtor Leverage and the Efficacy of Business Reorganization”, in Emory Bankr. Dev. J., vol. 27, 2010, pp. 213-253, pp. 227-229.

311 Michelle M. HARNER, “Activist Distressed Debtholders: the New Barbarians at the Gate”, in Wash. U. L. Rev., vol. 89, 2011, pp. 155-206. 
confirmado se fosse obtido com o favorecimento de um credor, ${ }^{312}$ o BGH entendeu que a aquisição de créditos poderia servir como instrumento para a obtenção de força deliberativa, prejudicando os demais credores de uma classe. Dessa forma, considerou que a aquisição de créditos só poderia ser realizada se fosse ofertado o mesmo valor a todos os credores de cada classe. ${ }^{313}$ Também a doutrina, interpretando o §250(2) da InsO, que proíbe a homologação de plano aprovado irregularmente, considera que a manipulação de maiorias deliberativas configura comportamento contrário à boa-fé. Um dos comportamentos vedados, nessa linha, é a aquisição de créditos com o objetivo exclusivo de obter maioria apta a conferir o poder de aprovação ou de veto em uma classe de créditos. $^{314}$

Na Itália, a questão recebe tratamento legislativo diverso, com a determinação de que as cessões de crédito posteriores à declaração de falência não atribuem aos credores cessionários direito de voto no concordato fallimentare. ${ }^{315}$ Segundo Roberto Sacchi, a ratio desse artigo seria a presunção de que o crédito foi adquirido em manobra dirigida a influenciar a votação, e de que, por conta disso, o cessionário se encontra em situação de incompatibilidade de interesses com os demais credores. ${ }^{316}$ Para o autor, a regra deveria ser aplicada por analogia também ao concordato preventivo. ${ }^{317}$

\subsubsection{EXERcício do DIREITO DE VOTO EM CASO DE CESSÃo DE CRÉdito DURANTE O PROCEDIMENTO DE RECUPERAÇÃO JUDICIAL}

Na Lei de Recuperação e Falência, não há previsão expressa sobre os efeitos da cessão de crédito ocorrida no curso de procedimento de recuperação judicial. Necessário indagar, portanto, sua viabilidade e a possibilidade de que o cessionário exerça os direitos de voto pertinentes ao direito de crédito no âmbito do procedimento concursal.

\footnotetext{
$312 \quad \mathrm{InsO}, \S 250(2)$.

313 BGH, IX ZB 153/04, j. 03.03.2005.

314 HARALD HESS, Insolvenzrecht, cit., §250, Rn. 13, p. 3515.

315 Leg. Fall., art. 127: "I trasferimenti di crediti avvenuti dopo la dichiarazione di fallimento non attribuiscono diritto di voto, salvo che siano effettuati a favore di banche o altri intermediari finanziari."

316 ROBERTO SACCHI, Il principio di maggioranza nel concordato e nell 'amministrazione controllata, cit., p. 461.

$317 \quad$ Id., p. 462.
} 
Na jurisprudência paulista, a questão já foi objeto de decisão. O Tribunal de Justiça considerou lícita a cessão de crédito no âmbito do procedimento de recuperação judicial e considerou que o credor cessionário pode exercer o direito de voto relativo ao crédito. ${ }^{318}$ $\mathrm{Na}$ fundamentação da decisão, o Tribunal considerou que o credor pode ceder o seu crédito, se a isso não se opuser a natureza da obrigação, a lei ou a convenção com o devedor (CC, art. 286) e que, salvo disposição em contrário, abrangem-se, na cessão de um crédito, todos os seus acessórios (CC, art. 287). Assim, considerou que o direito de voto é acessório do crédito, de forma que, com a cessão do crédito, o cessionário adquiriria também o direito de voto. Por conta disso, decidiu-se que o credor cessionário tem "direito de participar da Assembléia Geral de Credores com voz e voto, este na proporção do valor do crédito que lhe foi cedido, bastando para tanto, que tenha pedido sua habilitação, formulado divergência ou deduzido impugnação judicial, até que esta seja definitivamente julgada." 319 A doutrina acompanha o entendimento, frisando, porém, que abusos, fraudes ou excessos devem ser punidos por meio do impedimento da concessão de recuperação judicial. $^{320}$

O posicionamento é acertado, mas a argumentação é passível de críticas. Efetivamente, a cessão de créditos entre privados é lícita e o início de procedimento concursal não influencia a validade do negócio jurídico de cessão do crédito. Entretanto, uma questão diversa, não abordada pelo Tribunal, diz respeito à possibilidade de o cessionário substituir o credor original no processo de recuperação judicial, sub-rogando-se não apenas na posição jurídica de direito material, mas também processual.

Diante da ausência de regramento da questão na legislação concursal, aplica-se, subsidiariamente, o disposto no Código de Processo Civil (LRF, art. 189). Esse, por sua vez, determina que a alienação de direito litigioso a título particular, por ato entre vivos, não altera a legitimidade das partes (CPC, art. 42) e que, na cessão de crédito litigioso, o cessionário poderá intervir no processo, assistindo o cedente ( $\mathrm{CPC}$, art. $\left.42, \S 2^{\circ}\right)$, mas não poderá substituí-lo sem o consentimento da parte contrária (CPC, art. 42, $\left.\S 1^{\circ}\right)$. No entanto, há regra especial para o procedimento de execução, determinando que o cessionário pode

318 TJSP, AI n. 429.557-4/4-00, Câm. Esp. de Fal. e Rec. Jud., REl. DeS. PEREIRA CAlÇAS, v.u., j. 15.03.2006, DJ 14.04.2006.

$319 \quad$ Id.

320 Luiz Fernando VAlente de Paiva, Giuliano Colombo, "Recuperação Judicial e Cessão de Créditos: A Polêmica do Direito de Voto", in Revista do Advogado, n. 105, 2009, pp. 107-114, p. 114. 
promover a execução, ou nela prosseguir, quando o direito resultante do título executivo lhe foi transferido por ato entre vivos (CPC, art. 567, II).

A doutrina processualista é unânime no sentido de que se deve distinguir a cessão de crédito na pendência de processo de conhecimento da cessão de crédito depois de constituído o título executivo, considerando que a regra do art. 567, II do CPC tem caráter especial em relação à norma contida no artigo 42 do CPC. Assim, se a cessão for de crédito cujo título executivo já estiver constítudo, o ingresso do cessionário no pólo processual (substituição da parte) é possível. ${ }^{321}$ Esse entendimento foi recentemente sufragado pela Corte Especial do Superior Tribunal de Justiça, em decisão de recurso especial representativo de controvérsia (CPC, art. 543-C), dotado de eficácia vinculante. ${ }^{322}$ Se a cessão for de crédito ou título executivo não constituído, normalmente, não é lícita a substituição processual.

Do procedimento de recuperação judicial e de falência podem tomar parte tanto credores munidos de título executivo judicial ou extrajudicial como credores de quantias ilíquidas, que poderão pleitear a reserva de importância estimada de seu crédito pelo juízo da recuperação judicial, enquanto prossegue a ação de conhecimento. ${ }^{323} \mathrm{Com}$ base nisso, seria possível sustentar que a cessão de crédito apenas autoriza a substituição processual e, com ela, a alteração da legitimidade para o exercício de direito de voto, dos cessionários de créditos dotados de executividade.

Embora o objetivo da norma contida no artigo 42 do CPC seja o de garantir ao devedor a estabilidade da relação processual enquanto estiver em debate o montante do débito que lhe está sendo imputado, não se pode compartilhar tal entendimento. No procedimento de recuperação judicial, a aplicação da norma disposta no artigo 42 do CPC deve ser precedida por uma análise de sua compatibilidade com o objetivo do procedimento e da finalidade da atribuição de direito de voto aos credores. O direito de voto é atribuído para

321 CÂNDido R. DinAmarco, Instituições de Direito Processual Civil, vol. 4, $3^{\mathrm{a}}$ ed., São Paulo, Malheiros, 2009, p. 144; Humberto Theodoro JR., Curso de Direito Processual Civil, vol. 2, 46 ${ }^{\mathrm{a}}$ ed., Rio de Janeiro, Forense, 2011, p. 159; ARAKEN DE ASsis, Comentários ao Código de Processo Civil, vol. 4, Rio de Janeiro, Forense, 2009, pp. 66-67.

322 STJ, REsp n. 1.091.443-SP, Corte Esp., Rel. Min. Maria Thereza de Assis Moura, v.u., j. 02.05.2012, DJe 29.05.2012.

323 Mauro Rodrigues Penteado, in Francisco S. De Souza Jr., Antônio S. A. DE M. Pitombo (coord.), Comentários à Lei de Recuperação de Empresas e Falência, cit., p. 138. 
que os credores, economicamente interessados na melhor satisfação de seu crédito, exerçam coletivamente seu juízo de valor sobre a viabilidade do devedor e sobre a conveniência de aceitar plano de recuperação judicial que altera as condições originais de pagamento de seu crédito ( $\mathrm{LRF}$, art. 45, $3^{\circ}$ ), promovendo sua novação (LRF, art. 59). Com base nisso, a substituição processual apresenta-se como instrumento necessário para a efetiva tutela dos interesses do novo credor, ainda que seu crédito não esteja constituído, pois sofrerá diretamente as consequências econômicas de eventual plano de recuperação judicial.

Ademais, ao considerar que o direito de voto possa ser considerado um acessório do direito de crédito, o Tribunal adotou argumentação inapta a esclarecer certas situações previstas na lei. Caso seja cedido crédito trabalhista, por exemplo, há previsão expressa de que o credor cessionário assume a posição jurídica de credor quirografário (LRF, art. $83, \S^{\circ}$ ). Não parece possível compatibilizar essa regra com o argumento de que o voto é um acessório do direito de crédito.

Parece mais adequado considerar que, ao integrar a comunhão de credores e habilitar seu crédito, o credor adquire o status de credor concursal, posição jurídica subjetiva complexa integrada por deveres, direitos e poderes de ordem processual e material (e que pressupõe, para sua obtenção, habilitação tempestiva - LRF, art. $\left.10, \S 1^{\circ}\right)$. O direito de voto é um dos poderes outorgados aos credores que integram o processo recuperacional. Na cessão de crédito após o início do procedimento concursal, ocorre substituição processual, e o novo credor assume tanto a posição jurídica de direito material, como o status de credor no procedimento de recuperação judicial. Explica-se, com isso, a circunstância de que o credor cessionário, normalmente, assuma o status com a mesma conformação do credor original. Aclara-se, ademais, a possibilidade de imposição de restrições ao credor cessionário antes não impostas ao credor original - como, por exemplo, o impedimento de voto, caso o credor cessionário seja pessoa relacionada no art. 43 da LRF.

De toda forma, o posicionamento do Tribunal de Justiça é adequado no mérito, pois não há proibição à cessão de crédito no curso do procedimento recuperacional, nem à substituição processual. 


\subsubsection{ABUSO DO DIREITO DE VOTO POR CREDOR CESSIONÁRIO}

Pode-se questionar então se é lícito o exercício do direito de voto por um investidor que adquira uma posição majoritária em uma determinada classe, obtendo poder de veto em relação ao plano de recuperação judicial, e utilize esse poder para aumentar a satisfação de seu crédito.

Seria possível considerar que, ao adquirir créditos, um investidor não está, como os demais credores, movido pelo interesse em minorar suas perdas, mas pelo interesse em maximizar seu retorno financeiro. Ao utilizar o poder de voto relativo aos créditos adquiridos para essa finalidade, haveria abuso do direito de voto.

O argumento não convence. Em primeiro lugar, não há ilegalidade na obtenção de poder de controle ou de veto em uma classe. Um credor pode se ver, por circunstâncias alheias a sua vontade - com o repentino início de procedimento concursal -, na condição de único credor integrante de uma classe. Pode, por outro lado, não ter poder para influenciar a deliberação. Assim, se a lei admite maiorias espontâneas e, no âmbito dessas, admite que haja credores com poder de veto em relação a um plano proposto (é o caso do credor único em uma classe; não é possível a aprovação sequer na forma do art. 58 da LRF), não se pode considerar que a obtenção dessa maioria por meio negocial torne abusivo o voto exercido com base no poder assim obtido. Adicionalmente, o argumento de que haveria uma contradição entre o interesse do investidor - que busca incrementar seu retorno financeiro - e o interesse dos demais credores - interessados apenas em minorar suas perdas - não pode ser considerado mais do que análise sociológica (por presunção) que não afeta a circunstância de que, em ambos os casos, o credor, original ou investidor, está agindo em sua qualidade de credor para obter a maior satisfação de seu direito de crédito. Não há, portanto, contradição entre o objetivo de ganhar mais e o objetivo de perder menos, que são, antes, expressões de um mesmo interesse visto de ângulos diversos.

Assim, a obtenção de posição de domínio em uma determinada classe não é vedada, e tampouco o exercício de direito de voto com base nessa posição é abusivo somente por conta do aumento de poder do credor em relação aos demais credores dispersos. 


\subsubsection{CREDOR COM GARANTIAS PRESTADAS POR TERCEIROS}

A Lei de Recuperação e Falência prevê que o plano de recuperação judicial "implica novação dos créditos anteriores ao pedido, e obriga o devedor e todos os credores a ele sujeitos, sem prejuízo das garantias, observado o disposto no $\S 1^{\circ}$ do art. 50" (LRF, art. 59); e determina que "credores do devedor em recuperação judicial conservam seus direitos e privilégios contra os coobrigados, fiadores e obrigados de regresso" (LRF, art. $\left.49, \S 1^{\circ}\right)$. No que toca às garantias reais, determina-se que, "na alienação de bem objeto de garantia real, a supressão da garantia ou sua substituição somente serão admitidas mediante aprovação expressa do credor titular da respectiva garantia” (LRF, art. 50, $\S 1^{\circ}$ ).

\subsubsection{EFEITOS DA NOVAÇÃo RECUPERACIONAL SOBRE GARANTIAS PRESTADAS POR TERCEIROS}

A doutrina diverge acerca dos efeitos da aprovação de plano de recuperação judicial sobre créditos com garantia real ou pessoal prestada por terceiros, que, no mais das vezes, são os próprios sócios de sociedade devedora. Parte da doutrina considera que garantias pessoais previamente ajustadas não podem ser anuladas sob pena de se provocar elevação do custo de crédito, ${ }^{324}$ mas que, quanto às garantias reais, deve-se considerar que, como acessório, seguem o crédito, seu principal, e não podem ser excutidas de imediato. ${ }^{325}$ Outra parte da doutrina pondera que a novação acarreta necessariamente a extinção do penhor, da hipoteca ou da anticrese (CC, art. 364, parte final); a exoneração do fiador, se a novação operar sem seu consenso (CC, art. 366) e a exoneração dos devedores solidários (CC, art. 367), argumentando, por isso, que a expressão "sem prejuízo das garantias" utilizada no artigo 59 da LRF não diz respeito à fiança, aos direitos reais de garantia, nem à obrigação

\footnotetext{
324 É o que defende Rachel SzTajn (in Francisco S. DE Souza JR., Antônio S. A. DE M. Pitombo (coord.), Comentários à Lei de Recuperação de Empresas e Falência, cit., pp. 228-229). Com ponto de vista semelhante, cf. Jorge Lobo, in PAUlo F. C. S. DE TOledo e CARlOS H. ABRÃo (coord.), Comentários à Lei de Recuperação de Empresas e Falência, cit., pp. 117-118; MANOEL J. BEZERRA FILHO, "A Responsabilidade do Garantidor na Recuperação Judicial do Garantido", in Revista do Advogado, n. 105, 2009, pp. 129-134. Sob o regime da Decreto-Lei n. 7.661/45, o artigo 148 determinava que "a concordata não produz novação". A doutrina era, assim, unânime em negar a extensão dos efeitos a coobrigados. Cf.: Trajano de Miranda Valverde, Comentários à Lei de Falências, vol. 2, 4ª ed. atual. por J. A. PenAlva Santos e Paulo Penalva Santos, Rio de Janeiro, Forense, 1999, pp. 262-264; e FÁbio K. Comparato, "Responsabilidade do Avalista na Concordata Preventiva do Avalizado", in Direito Empresarial: Estudos e Pareceres, São Paulo, Saraiva, 1995, pp. 476-490, pp. 485-490.

325 Rachel Sztajn, in Francisco S. DE Souza JR., Antônio S. A. DE M. Pitombo (coord.), Comentários à Lei de Recuperação de Empresas e Falência, cit., p. 229.
} 
solidária de outros devedores. ${ }^{326}$ Coobrigados, fiadores e obrigados de regresso seriam excluídos dos efeitos do processo de recuperação judicial, mas, caso o direito de crédito contra eles detido fosse novado, as garantias seguiriam a sorte do principal. ${ }^{327}$

Na jurisprudência, a questão vem sendo objeto de debate. No Tribunal paulista, é assente o entendimento de que a novação produzida pelo plano não se estende a garantidores, avalistas e fiadores. ${ }^{328}$ No Superior Tribunal de Justiça, a matéria foi uniformizada pela Segunda Seção, no sentido de que o deferimento de recuperação judicial à empresa coexecutada "não tem o condão de suspender a execução em relação a seus avalistas, à exceção do sócio com responsabilidade ilimitada e solidária" e de que "os credores sujeitos aos efeitos da recuperação judicial conservam intactos seus direitos e, por lógica, podem executar o avalista desse título de crédito". ${ }^{329}$ Não há, contudo, posicionamento uniforme a respeito do efeito da novação sobre a garantia real prestada por terceiro.

Em suma, tem prevalecido na jurisprudência o entendimento de que o credor sujeito a recuperação judicial que conte com garantia pessoal prestada por terceiro - ainda que sócio, ou acionista da sociedade devedora - mantém seus direitos em face do garantidor, mesmo que seja aprovado plano de recuperação judicial com novação de seu crédito. Já quanto ao credor com garantia real prestada por terceiro, não há posicionamento definido, mas há manifestações no sentido da não afetação da garantia por eventual novação do crédito no âmbito da recuperação judicial.

\footnotetext{
326 Eduardo S. Munhoz, in Francisco S. De Souza Jr., Antônio S. A. DE M. Pitombo (coord.), Comentários à Lei de Recuperação de Empresas e Falência, cit., p. 294.

$327 \quad$ Id., p. 294.

328 No Tribunal de Justiça de São Paulo, prevalece o entendimento de que a novação operada pelo aprovação de plano de recuperação judicial não atinge as obrigações de coobrigados, fiadores e avalistas (cf., por todos, voto proferido pelo DES. PEREIRA CALÇAS, colacionando jurisprudência e doutrina nacional e comparada: TJSP, AI n. 0322490-94.2010.8.26.0000, Câm. Res. à Fal. e Rec., REL. DES. PEREIRA CALÇAS, v.u., j. 01.02.2011, DJ 09.02.2011. No mesmo sentido, TJSP, AI n. 0103033-89.2012.8.26.0000, Câm. Res. Dir. Emp., REL. DES. RoBERTO MAC CRACKEN, v.u., j. 06.11.2012, DJ 21.11.2012.

329 STJ, EDiv em AG n. 1.179.654-SP, $2^{\mathrm{a}}$ Seção, REL. Min. SiDNEI BENETTI, v.u., j. 08.03.2012, DJe 13.04.2012. No mesmo sentido, mas aplicando o disposto no art. 24 do Decreto Lei 7.661/45, cf. STJ, REsp n. 883.859-SC, $3^{\mathrm{a}}$ T., REL. MIN. NANCY ANDRIGHI, v.u., j. 10.03.2009, DJe 23.03.2009; e AgRg no AI n. 812.533-SP, $4^{\mathrm{a}}$ T., REL. MIN. FERNANDO GONÇALVES, v.u., j. 04.03.2010, DJe 22.03.2010.
} 


\subsubsection{VOTO EXERCIDO PELO CREDOR GARANTIDO POR TERCEIRO EM DETRIMENTO DOS DEMAIS CREDORES}

A possibilidade de prosseguimento de ações e execuções contra devedores solidários, fiadores e avalistas e a possibilidade de excussão de garantia real prestada por terceiro podem ser relevantes para sobre o procedimento de deliberação dos credores acerca do plano de recuperação judicial.

O credor com garantia real ou pessoal prestada por terceiro é considerado, na recuperação judicial, integrante da classe III, composta pelos credores quirografários, com privilégio especial, privilégio geral e subordinados. ${ }^{330}$ Os credores da classe III, por sua vez, estão situados, na ordem de preferência falimentar, em posição inferior aos credores integrantes das classes I e II (LRF, art. 83). Naturalmente, todos os credores afetados pelo plano devem comparar a posição em que serão situados sob um plano de recuperação judicial e com aquela em que estariam em caso de falência. Em linha de princípio, credores situados em nível menos privilegiado terão maior incentivo a aceitar um plano de recuperação judicial. ${ }^{331}$. É em torno dessa condição que a Lei de Recuperação e Falência organiza os credores em classes, ainda que de forma criticável (cf. item 2.3.1.2.1, supra). O problema é que o credor garantido por terceiro analisará um plano de recuperação judicial partindo de premissas diversas daquelas assumidas pelos demais credores integrantes da classe III.

O credor com garantia prestada por terceiro terá maior probabilidade de satisfação de seu crédito, já que poderá agredir diretamente o patrimônio do garantidor ou excutir o bem dado em garantia. Para o credor garantido, portanto, é menor o risco associado à falência do devedor. Ao aceitar um plano de recuperação judicial, no entanto, seu posicionamento possa ser entendido como uma aquiescência à modificação da condição de seu crédito em relação ao terceiro garantidor. Assim, ainda que a jurisprudência atual entenda que o

\footnotetext{
$330 \quad$ Nesse sentido, cf. "Recuperação Judicial. Crédito com garantia real prestada por terceiro. Hipótese em que deve ser classificado, no quadro geral como quirografário porque não afasta, especificamente, qualquer bem do patrimônio da devedora. Reclassificação determinada.” (TJSP, AI n. 531.656-4/5-00, Câm. Esp. Fal. e Rec. Jud., Rel. Des. Costa Telles, v.u., j. 19.12.2007, DJe 10.01.2008). No mesmo sentido, TJSP, AI n. 0211493-73.2012.8.26.0000, 1ª Câm. Res. Dir. Emp., Rel. Des. PereIRA CalÇAS, v.u., j. 30.10.2012, DJ 01.11.2012.

331 Nesse sentido, Jeremy I. Bulow, John B. Shoven, “The Bankruptcy Decision”, in Bell J. Econ., vol. 9, 1978, pp. 437-456, p. 448.
} 
crédito contra o terceiro garantidor não é afetado pela novação, há, sob o plano fático, um risco maior associado à aprovação do plano. ${ }^{332}$

No direito italiano, problema semelhante gerou polêmica sobre a participação dos credores com garantia prestada por terceiro no procedimento deliberativo acerca do concordato preventivo. Como dele somente tomavam parte credores quirografários, parte da doutrina entendia que os credores com garantia prestada por terceiros não eram titulares de interesse compatível com o dos demais credores quirografários na busca por uma solução consensual para o estado de crise. ${ }^{333}$ Em posição a respeito do assunto, Roberto Sacchi defendeu que os credores garantidos por terceiros, bem como os credores com garantia real sobre bens do devedor, não sofriam o mesmo sacrifício que os credores quirografários e que, portanto, não poderiam concorrer à eventual aceitação de uma limitação de direitos pelos credores quirografários. ${ }^{334}$ Segundo o autor, os credores garantidos por terceiros deveriam ser excluídos de deliberações sobre o concordato (defendendo, portanto, o impedimento de voto), pois a garantia real ou pessoal conferida por terceiro aumenta a probabilidade de satisfação do crédito, gerando uma peculiar heterogeneidade entre os interesses dos credores quirografários. ${ }^{335}$

No atual sistema falimentar italiano foram sujeitos ao concordato os credores com garantia real, mas foi adotado sistema de classeamento flexível, com agrupamento de credores em classes de créditos homogêneos. A questão, portanto, deixa de ser enfrentada sob a perspectiva do impedimento de voto e passa a ser equalizada por meio do adequado enquadramento dos credores. Ainda assim, a circunstância de que um credor conte com garantia prestada por terceiro é considerada justificativa suficiente para seu enquadramento em classe apartada em relação a outros credores quirografários. ${ }^{336}$

\footnotetext{
332 Note-se que, nas decisões do Tribunal de Justiça mencionadas, o credor sempre ressalvou expressamente seu direito de prosseguir a execução em face do garantidor e a não sujeição desse crédito aos efeitos do plano de recuperação judicial. Não é claro, portanto, o posicionamento do Tribunal do Justiça de São Paulo, ou do Superior Tribunal de Justiça a respeito dos efeitos jurídicos de um plano aprovado pelo credor garantido que não tenha ressalvado a não sujeição de seu crédito em face do coobrigado.

333 SALVATORE SATTA, "Voto, nel condordato preventivo di società, di creditore pignoratizio garantito dagli azionisti”, in Dir. Fall., vol. 46, parte I, 1971, pp. 201-204.

334 ROBERTO SACCHI, Il principio di maggioranza nel concordato e nell'amministrazione controllata, cit., p. 446.

$335 \quad$ Id., p. 450.

336 Nesse sentido, defende MASSIMO FABIANI que "[t]ratar formalmente, na exata mesma medida, dois credores quirografários, sendo que um deles possui garantia sobre bem de terceiro, significa, em realidade, fornecer a base para um tratamento desigual" ("Brevi riflessioni su omogeneità degli interessi ed
} 
No direito brasileiro, não parece possível defender que o credor que desfrute de garantia pessoal ou real prestada por terceiro esteja impedido de votar (cf. item 3.3, supra). Entretanto, pode-se questionar se seria possível o abuso do direito de voto pelo credor que evita a aprovação de um plano de recuperação judicial apenas para garantir que não haverá alteração de seu crédito.

Aparentemente, a preocupação poderia parecer infundada, pois, de acordo com a orientação jurisprudencial predominante, a eventual alteração do crédito pela novação não afetaria a possibilidade de obter satisfação perante o terceiro. Para o credor, a decisão de buscar a satisfação em face do devedor seria pautada pelas mesmas considerações, e tomando o mesmo referencial, que os demais credores da classe III.

Mas a prevalecer entendimento jurisprudencial diverso, há possibilidade de abuso do direito de voto, como já reconheceu o Tribunal de Justiça do Rio de Janeiro, ${ }^{337}$ em caso referente a plano de recuperação judicial aprovado pelas classes de credores I e II, mas que, na classe III, não obteve maioria dos créditos. Segundo o acórdão, a razão para a rejeição do plano seria o fato de que um dos credores, instituição financeira titular de grande volume de crédito, manifestara "sua intenção de cobrar seu crédito diretamente dos devedores solidários". Por conta disso, o acórdão entendeu que a postura adotada pela instituição financeira "ultrapass[ou] o exercício regular de um direito, já que abusiva e contrária aos interesses dos demais credores, em total afronta ao espírito da Lei". O acórdão fundamenta a decisão, ademais, no artigo 47 da LRF, mas não seria necessário recorrer a tanto.

Além disso, como já se apontou, algumas questões não estão completamente deslindadas. Se há novação do crédito pelo plano, e o sócio ofereceu um bem em hipoteca, não está claro se o credor garantido poderá excutir o bem e obter valor superior ao seu crédito novado. Essa circunstância pode motivar o credor a rejeitar um plano apenas para garantir que poderá excutir a garantia sem sofrer redução em seu crédito.

obbligatorietà delle classi nei concordati", cit., pp. 442: "Trattare formalmente nella stessa misura due creditori chirografari, uno dei quali possiede una garanzia su beni di terzi, significa, in realtà, porre le basi per un trattamento diseguale.”).

${ }^{337}$ TJRJ, AI n. 0037321-84.2011.8.19.0000, 5ª Câm. Cív., Rel. Des. Milton Fernandes De SouZA, v.u., j. 13.12.2011. 
A análise do abuso do direito exige atenção ao caso concreto. Se o credor rejeita um plano de recuperação judicial para garantir que não será prejudicada a satisfação de seu crédito por meio da execução em face do devedor solidário, fiador ou avalista, ou por meio da excussão de bem dado em garantia real, e há fundamentos concretos para considerar que o credor pautou sua decisão de não aceitar alteração a seu crédito por esse motivo, é possível que haja abuso do direito de voto. A questão, contudo, exige análise casuística e excesso "manifesto" aos limites impostos pela boa-fé. Se a garantia prestada pelo terceiro tinha poucas condições de levar à satisfação do crédito - por exemplo, pelo fato de já terem sido penhorados todos os bens do sócio limitadamente responsável -, tal fato deverá ser levado em consideração no caso concreto.

\subsubsection{CREDOR GARANTIDO POR ALIENAÇÃo FIDUCIÁria OU PENHOR DE PARTICIPAÇÕES SOCIETÁRIAS DA SOCIEDADE DEVEDORA}

Caso peculiar de credor garantido por terceiro é o do credor garantido por alienação fiduciária (como já indicado no item 3.4.2, supra) ou penhor de participações societárias. A peculiaridade, no caso, decorre do fato de que a aprovação de recuperação judicial pode ter como efeito uma conservação do valor das garantias de que os credores dispõem, ao passo que a falência pode tolher o seu valor. A aprovação de um plano de recuperação judicial, ainda que impondo sacrifícios desmedidos aos credores, poderá proporcionar vantagem particular a esse credor. Entretanto, não se nega que a apuração do abuso do direito de voto nessa situação não é simples, pois também o credor estará renunciado a parte de seu crédito para que seja aprovado o plano de recuperação judicial. Hipóteses de manifesto abuso (CC, art. 187) não tendem a ser frequentes, mas podem ocorrer.

\subsubsection{CREDOR COM CRÉDITOS EM MAIS DE UMA CLASSE}

Os credores são alocados pela Lei de Recuperação e Falência em três classes diversas, de acordo com a natureza do direito de crédito que detenham em face do devedor. É possível que uma mesma pessoa seja titular de créditos pertinentes a classes diversas, exercendo, com isso, direito de voto em mais de uma classe. 
Para julgar a conveniência de um plano de recuperação, cada credor compara sua situação sob o plano com aquela em que estará situado caso rejeite a proposta e seja declarada a falência do devedor. Quando uma mesma pessoa é titular de créditos integrantes de mais de uma classe, seu cálculo passa a ser peculiar. A cada parcela de seus créditos será conferido tratamento diverso na falência, mas, para o credor, interessa o resultado total. É possível, portanto, que o credor seja favorável a um plano que exija um sacrifício desmedido de parte de seus créditos, mas diminuto de outra parte. Abre-se, com isso, a possibilidade de que o credor se utilize de seu direito de voto em uma classe para proteger seus interesses em outra. Pense-se, por exemplo, na possível participação de credor concomitantemente na classe dos credores garantidos e na classe dos credores quirografários, por deter créditos de ambas as naturezas ou por ser insuficiente sua garantia. $^{338}$

No direito societário, são conhecidas situações semelhantes, sobretudo no que diz respeito ao acionista titular de ações ordinárias e preferenciais. ${ }^{339}$ O Colegiado da CVM já entendeu, em obiter dictum, que, se um acionista titular de ações ordinárias utilizasse seu poder de voto na classe dos acionistas preferenciais para privilegiar sua posição econômica global como titular de ações ordinárias, o voto assim proferido poderia ser considerado abusivo, e, portanto, anulável. ${ }^{340}$

No âmbito concursal, a questão merece tratamento semelhante. Trata-se do entendimento defendido por Charles J. Tabb nos Estados Unidos. Para o autor, há má-fé se o credor exerce o direito de voto em uma classe para privilegiar sua posição econômica global, ou sua posição econômica em outra classe: "um credor pode atuar em irremediável conflito de interesses ao exercer o direito de voto relativo a um de seus créditos, e o seu voto relativo a esse crédito pode ser anulado. Para ilustrar, o plano pode propor pagar mais à classe 3 , às

338 O exemplo é de SHEILA C. N. CEREZETTI (A Recuperação Judicial de Sociedade por Ações - O Princípio da Preservação da Empresa na Lei de Recuperação e Falência, cit., p. 304)

339 CVM, Processo Administrativo RJ 2006/6785, Rel Dir. PEDRo Oliva MARCILIO DE SouZA, v.m., j. 25.09.2006. Para resumo e análise da decisão, cf. DANIEL KALANSKY, Incorporação de Ações, São Paulo, Saraiva, 2012, pp. 203-210.

340 Declaração de Voto do Dir. Pres. Marcelo Fernandez Trindade, in CVM, Processo Administrativo RJ 2006/6785, Rel Dir. Pedro Oliva MARCILIO DE SOUZA, v.m., j. 25.09.2006. 
custas da classe 4 . O credor X, titular de créditos nas classes 3 e 4 , poderia votar na classe 3, mas talvez não na $4 . " 341$

Há, portanto, além de um dever de lealdade geral aos diversos credores, um dever de lealdade entre os integrantes de uma determinada classe, que, na visão de Karsten Schmidt, também formariam, por si, uma comunhão de interesses específica, contida no âmbito da comunhão de interesses existente entre todos os credores concursais. ${ }^{342}$ Assim, ao participar de mais de uma classe de créditos, o credor não poderá votar motivado por interesse alheio à satisfação do crédito que lhe atribuiu o direito de voto naquela respectiva classe. $^{343}$

Certamente, não é problema simples averiguar quando um credor integrante de uma classe se utiliza de seu crédito em uma classe para privilegiar seus interesse na condição de credor integrante de outra classe. Não obstante a dificuldade de aferição, uma forma de avaliar a ocorrência do abuso do direito de voto é a análise do comportamento esperado das partes. Os credores com prioridade na falência aceitarão, normalmente, menos restrições a seu crédito do que credores em nível inferior na ordem de preferência. Um modo de abuso do direito de voto pode ocorrer, por exemplo, quando o credor aceita imposição de maior restrição ao seu crédito com garantia, para assegurar, por outro lado, tratamento favorecido enquanto credor quirografário.

\subsubsection{CREDOR CONCORRENTE}

Por mais que seja possível a manutenção da atividade produtiva na falência (LRF, art. 57 c/c art. 140), é certo que a falência poderá trazer benefícios para concorrentes, pois, com o desapossamento do devedor, é menor a capacidade de que a empresa falida consiga disputar mercado em condição de igualdade com demais agentes econômicos. É possível

\footnotetext{
341 CHARLES J. TABB, The Law of Bankruptcy, cit., \$11.21, p. 1127: “[...] a creditor who holds claims in more than one class might labor under an irremediable conflict of interest in voting in one of the claims, and its vote on that claim could be designated. To illustrate, the plan might propose to pay class 3 more, at the expense of class 4; Creditor X, holding claims in both classes, could vote the class 3 claim, but perhaps not the class 4 claim."

342 KARSTEN SCHMIDT, “Das Recht der Mitgliedschaft: Ist ‘korporatives Denken’ passé?”, cit., p. 114.

343 Sheila C. N. CerezetTI, A Recuperação Judicial de Sociedade por Ações - O Princípio da Preservação da Empresa na Lei de Recuperação e Falência, cit., p. 303.
} 
questionar se haveria abuso do direito de voto pelo credor que, ao exercer o direito de voto, tem em vista benefícios que lhe possam advir em decorrência da falência do devedor.

A falência de um devedor pode atingir e afetar uma infinidade de agentes, em decorrência da alteração ao nível de concorrência praticado em um determinado mercado. Primeiramente, um credor diretamente concorrente pode se beneficiar. Imagine-se, ademais, que o principal concorrente da empresa devedora seja uma companhia aberta, com ações negociadas em bolsa. Com a falência do devedor, também essa companhia será beneficiada. Mediatamente, portanto, também o serão seus acionistas, dentre os quais podem constar credores da empresa devedora. Pode ocorrer, ademais, benefício a agentes que atuam em outro nível do processo produtivo. A falência do devedor que atua no processo de distribuição de um produto, por exemplo, pode favorecer a entrada nesse mercado de outros agentes que, até aquele momento, atuavam no processo de industrialização. São inúmeras, portanto, as possíveis repercussões da alteração do nível de concorrência em determinado mercado.

No direito norte-americano, já se admitiu que o voto de um credor motivado pela tentativa de retirar do mercado empresa concorrente poderia ser considerado como de má-fé. No caso In re MacLeod, antigos administradores da empresa devedora criaram uma sociedade para explorar atividade econômica diretamente concorrente com a da sociedade devedora. Nesse caso, entendeu-se que o direito de voto dos credores foi exercido com o "motivo ulterior de destruir e causar dano à empresa do devedor, para promover os interesses da empresa concorrente a que os devedores estavam associados". 344

Também no direito brasileiro parece possível o abuso do direito de voto quando exercido por credor concorrente com o objetivo de conduzir o devedor à falência. É o que aponta Erasmo Valladão, ${ }^{345}$ ao analisar as hipóteses de vícios do voto.

Difícil é determinar, no caso concreto, quando a motivação do voto é a busca da falência do devedor. Uma possível separação de hipóteses poderia levar em consideração os casos em que o credor está praticando concorrência desleal; por exemplo, quando se aproveita da

\footnotetext{
$344 \quad$ In re MacLEOD, 63 B.R. 654 (1986), p. 655.

345 Erasmo V. A. e N. França, in Francisco S. de Souza Junior, Antônio SÉrgio A. DE M. PITOMBo (coord.), Comentários à Lei de Recuperação de Empresas e Falência, cit., p. 193.
} 
situação de crise da empresarial enfrentada pelo devedor para promover concorrência desleal (Lei n. 9.279/96, art. 195). Nessas situações, é mais evidente o benefício que advirá ao credor pela falência do devedor.

Já nas demais situações de mera concorrência, ou, ainda, de interesse econômico indireto do credor (por exemplo, por ser acionista de companhia concorrente), será preciso analisar se a falência efetivamente resultaria em alteração relevante no mercado, de forma a motivar o credor a buscar a falência do devedor. Se essa correlação puder ser estabelecida de forma clara, e se o credor exercer, de forma manifesta, interesse ulterior em retirar o devedor do mercado, haverá abuso do direito de voto.

\subsubsection{RISCO DE SUJEIÇÃo À INEFICÁCIA OU À REVOGAÇão EM CASO DE FALÊNCIA}

Na deliberação acerca do plano de recuperação judicial, a consequência da rejeição do

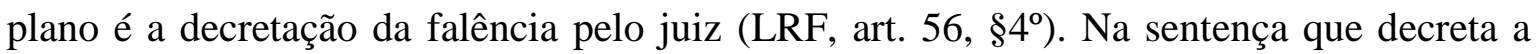
falência, cabe ao magistrado fixar seu termo legal, que poderá ser retrotraído até noventa dias do pedido de falência, do pedido de recuperação judicial ou do primeiro protesto por falta de pagamento (LRF, art. 99, II). Considerando que os três marcos tomados pelo legislador dizem respeito a possíveis eventos que deflagram o procedimento concursal, o magistrado não é livre para fixar o termo legal com base em qualquer um desses marcos. Caso a falência tenha sido decretada por falta de pagamento, o termo base deve ser o primeiro protesto. Caso o motivo tenha sido uma das demais causas previstas no artigo 94 da LRF, o marco deve ser o pedido de falência. Já no caso de um plano de recuperação judicial ser rejeitado pelos credores, é do pedido de recuperação judicial, não da própria sentença, que deve partir a fixação do termo legal. ${ }^{346}$

Pelo termo legal, "tenha ou não o contratante conhecimento do estado de crise econômicofinanceira do devedor", e "seja ou não intenção deste fraudar credores", são ineficazes em relação à massa o pagamento de dívidas não vencidas (LRF, art. 129, I); o pagamento em forma diversa daquela prevista contratualmente (LRF, art. 129, II); e a constituição de direito real de garantia, tratando-se de dívida contraída anteriormente (LRF, art. 129, III). Também são ineficazes os atos praticados a título gratuito; a renúncia a herança ou a

346 Vera Helena de M. Franco, in Francisco S. De Souza Jr., Antônio S. A. De M. Pitombo (coord.), Comentários à Lei de Recuperação de Empresas e Falência, cit., p. 414. 
legado até dois anos antes da decretação da falência (LRF, art. 129, IV e VI); e a venda ou transferência de estabelecimento feita sem o consentimento expresso de todos os credores, exceto nas hipóteses previstas no artigo 129, VI da LRF. Por fim, são revogáveis os atos praticados com a intenção de prejudicar credores, provando-se o conluio fraudulento entre o devedor e o terceiro, bem como o prejuízo sofrido pela massa falida (LRF, art. 130).

O patrimônio do devedor é a garantia geral de que desfrutam os credores. ${ }^{347}$ Normalmente, cabe ao devedor conformar suas relações jurídicas patrimoniais da forma como lhe convier. Já na situação de crise, é necessário tutelar a massa patrimonial contra o desmantelamento que pode ser causado pelas ações individuais dos credores, ${ }^{348}$ motivo que fundamenta a suspensão do curso de ações e de execuções (LRF, art. $5^{\circ}, \S^{\circ} \mathrm{c} / \mathrm{c}$ art. 99, V). Entretanto, o processo de crise geralmente não advém instantaneamente. Sua aproximação é percebida antes pelo devedor e por credores com maior capacidade de monitoramento, razão pela qual também se mostra necessário proteger a comunhão de credores contra medidas tomadas durante a fase "crepuscular" que normalmente antecede a deflagração do procedimento concursal. ${ }^{349} \mathrm{E}$ durante essa fase que se concentra o maior risco de que o devedor, para evitar um procedimento concursal, aceite medidas altamente prejudiciais para si e, mediatamente, para os credores. ${ }^{350}$

Em linha com essa preocupação, a Lei de Recuperação e Falência considera crime a prática de ato de disposição, oneração patrimonial ou gerador de obrigação, destinado a favorecer um ou mais credores em prejuízo dos demais (LRF, art. 172). Contudo, há aqui uma divergência entre sanção penal e sanção civil. Enquanto a ineficácia e a revogação só atingem atos ocorridos antes da decretação da falência, a norma penal tipifica a prática do favorecimento de credores antes ou depois "da sentença que decretar a falência, conceder a recuperação judicial, ou homologar plano de recuperação extrajudicial”. Há, portanto, uma divergência entre o âmbito de aplicação das duas regras, embora tenham por objetivo a tutela dos credores contra a vulneração do patrimônio do devedor ocorrida antes da deflagração do procedimento.

\footnotetext{
347 PIERO PAJARDI, Radici e ideologie del fallimento, $2^{\mathrm{a}}$ ed., Milano, Giuffrè, 2002, p. 51.

348 THOMAS H. JACKSON, The Logics and Limits of Bankruptcy Law, cit., pp. 7-19. Note-se, entretanto, que embora essa seja uma das funções do sistema concursal, não é possível concordar com a proposição do autor, de que seja a única. Para uma crítica à insuficiência explanatória do posicionamento de Jackson, cf. ELIZABETH WARREN, "Bankruptcy Policy”, cit., pp. 775-814.

349 LORENZO STANGHELLINI, Le crisi di impresa fra diritto ed economia, cit., pp. 264-268.

$350 \quad$ HORST EIDENMÜLLER, Unternehmenssanierung zwischen Markt und Gesetz, cit., p. 22.
} 
Caso um credor, antes do início do procedimento de recuperação judicial, celebre com o devedor contrato prejudicial aos demais credores, deve haver sanção penal para o devedor (LRF, art. 172), mas o ato não estará sujeito a revogação, a menos que seja decretada a falência do devedor (LRF, art. 130). Tampouco pode ser considerado ato em fraude a credores, pois esta pressupõe o estado de insolvência do devedor (CC, art. 158 a art. 165), que não é pressuposto para a propositura de pedido de recuperação judicial (LRF, art. 48). Ademais, caso seja praticado um dos atos sujeitos a ineficácia no caso da decretação de falência, como, por exemplo, o pagamento de parte das dívidas não vencidas a um credor (LRF, art. 129, I), o ato permanecerá eficaz caso seja aprovado plano de recuperação judicial.

Nesses casos, portanto, o credor que celebrou com o devedor negócios jurídicos passíveis de sofrer a sanção de ineficácia ou de revogação caso haja decretação da falência terá especial interesse de ver aprovado qualquer plano de recuperação judicial, mesmo que implique sacrifício desmedido de seu crédito. Com isso, o credor será poupado de uma consequência negativa que atingiria sua posição jurídica, mas não a de demais credores. Obtém, portanto, por meio do exercício do direito de voto, uma vantagem particular de que os outros credores não desfrutam ao aprovar um plano de recuperação judicial.

Diante desse quadro, tendo em vista a relevância do ato sujeito à ineficácia ou revogação, e caso seja possível considerar que, no caso concreto, o credor age de forma "manifestamente" (CC, art. 187) abusiva para evitar a ocorrência da ineficácia ou da revogação, pode ocorrer abuso do direito de voto.

\subsection{ABUSO NEGATIVO DO DIREITO DE VOTO: VETO OBSTRUTIVO}

O abuso negativo do direito de voto se caracteriza pela adoção de comportamento obstrutivo em prejuízo da comunhão de credores. Com a designação de "comportamento obstrutivo", define-se aqui a conduta de determinado credor que, não sendo prejudicado por um plano de recuperação judicial exerce seu direito de voto para provocar a rejeição do plano. Não há, na Lei de Recuperação e Falência, nenhum dispositivo expresso que vede essa forma de atuação. Se o plano propõe uma alteração de qualquer monta ao crédito de um credor, ele terá direito a voto ( $\mathrm{LRF}$, art. $\left.45, \S 3^{\circ}\right)$ e poderá exercê-lo para rejeitar o 
plano. Em outros países, essa situação é enfrentada por meio de mecanismos institucionais que permitem a desconsideração do exercício de direito de voto que possa ser considerado obstrutivo.

\subsubsection{INSTRUMENTOS PARA A SUPERAÇÃO DO VETO ABUSIVO}

Outros ordenamentos jurídicos preveêm instrumentos específicos para superação do veto obstrutivo. Entre esses, o sistema de cram down norte-americano é um referencial influente e significativo. Ademais, é interessante analisar o mecanismo de proibição de obstrução (Obstruktionsverbot) adotado na Alemanha, inspirado, em ampla medida, no modelo norteamericano, mas que, transposto para uma legislação ainda mais protetiva dos interesses dos credores, tomou conformação diversa da que tem nos Estados Unidos.

\subsubsection{ESTADOS UNIDOS}

No direito norte-americano, a superação do veto por um credor é viabilizada por meio do chamado cram down. As regras que pautam esse instituto são claras, mas, como poucas, nada reveladoras do que efetivamente se passa na realidade. Lê-las, sem conhecer seu histórico ou, ao menos, o contexto prático em que estão inseridas, é de pouca valia. É necessário, portanto, analisar o instituto cuidadosamente.

O direito norte-americano confere grande proteção aos credores, mas considera impossível esperar que seja sempre obtida unanimidade para que um plano de reorganização seja aprovado. ${ }^{351}$ No procedimento de reorganization norte-americano, ${ }^{352}$ o proponente deve separar os credores (claim holders) e os titulares de participação societária (interest holders) - aqui simplesmente referidos conjuntamente como credores - em classes de

\footnotetext{
$351 \quad$ "Experience makes it certain that generally there will be at least a small minority of creditors who will resist a composition, however fair and reasonable, if the law does not subject them to a pressure to obey the general will." Ashton et al. v. Cameron Water Improvement District No. One, 298 U.S. 513 (1936), p. 541.

352 Pelos limites do presente tópico, serão expostos apenas os aspectos tidos como mais relevantes para a compreensão do funcionamento e da atuação do mecanismo de cram down. Para uma exposição mais ampla acerca do assunto, cf. CHARLES J. TABB, The Law of Bankruptcy, cit., §11.20, pp. 1098-1201. Em português, cf. SHEILA C. N. CeREZETTI, "O Papel dos Credores no Bankruptcy Code”, in RDM, vol. 151/152, 2009, pp. 164-186; e CARolina S. J. BATISTA, PAUlo FERnANDO CAMPANA Filho, RENATA Y. MiYAZAKI, e Sheila C. N. CerezeTti, "A Prevalência da Vontade da Assembleia Geral de Credores em Questão: o Cram Down e a Apreciação Judicial do Plano Aprovado por todas as Classes", in RDM, vol. 143, 2006, pp. 202242, pp. 204-209.
} 
créditos “essencialmente similares" $(\mathrm{BC}, \S 1122) .{ }^{353} \mathrm{O}$ plano deverá prever tratamento igual aos credores em cada classe, e diferenciações dentro da classe apenas são permitidas com o consenso do credor discriminado (BC, §1123(a)(4)). Todavia, é possível o tratamento diferenciado de credores integrantes de classes diversas, ainda que as classes sejam compostas por créditos com a mesma ordem de prioridade falimentar. A votação acerca do plano ocorre conforme classes de credores. A classe que não sofre alteração das condições de seu crédito (unimpaired) não vota, e é tida como favorável ao plano (BC, §1126(f)); já os demais credores votam por classe. Para a confirmação do plano, todas as classes devem aceitá-lo (BC, $\$ 1129$ (a)(8)(b)). Caso esse resultado não seja obtido, mas ao menos uma classe tenha aceitado o plano, é possível que as classes rejeitantes tenham seu veto superado, o que se denomina "cram down"354.

Para a aprovação em cada classe, ${ }^{355}$ diferentes maiorias são exigidas para credores e para titulares de participação societária. A aprovação em cada classe de credores exige que a maioria dos credores contados por cabeça e que dois terços dos credores contados por valor dos créditos aceitem o plano (BC, §1126 (c)). Dentre os titulares de participação societária, exige-se maioria de dois terços do valor dos créditos (BC, §1126 (d)).

A aprovação do plano, ou sua imposição pela via do cram down, é apenas um dos dezesseis requisitos que devem ser preenchidos para sua homologação pelo tribunal (BC, $\S 1129(\mathrm{a})) .{ }^{356}$ Entre os requisitos, um deles é denominado como teste do melhor interesse do credor (best-interests-test). O princípio é de que nenhum credor pode receber, sob o plano, tratamento inferior ao que receberia na hipótese de liquidação (prevista no Chapter 7 do BC). Isso significa que "todos os credores e titulares de participação societária são titulares de um poder de veto limitado sobre os termos do plano regido pelo Chapter

353 Cf. SCOTT F. NORNBERG, "Classification of Claims Under Chapter 11 of the Bankruptcy Code: The Fallacy of Interest Based Classification”, cit., pp. 119-166.

354 A expressão que designa o instituto está ligada a seu caráter impositivo, e poderia ser traduzida livremente como "impor goela abaixo".

355 O processo de votação não é presencial. Ao submeter um plano ao tribunal, o proponente deve apresentar um documento informativo (disclosure statement) que forneça informações adequadas aos credores sobre a situação do devedor e sobre o plano, para que eles tomem decisão informada. Após o conteúdo informativo ser aprovado pelo magsitrado, será enviado um conjunto de documentos que incluem (i) o material informativo; (ii) cópia da decisão judicial que o aprova; (iii) cartão para o voto; (iv) o plano, ou um resumo aprovado pela corte; (v) informações sobre o cronograma do procedimento de votação. As votações são, então, recolhidas à distância. CHARLES J. TABB, The Law of Bankruptcy, cit., §11.20, p. 11191120.

356 Sobre o assunto, cf. CHARLES J. TABB, The Law of Bankruptcy, cit., §11.20, pp. 1132-1134. 
11".357 Embora uma classe possa aceitar um tratamento inferior ao que receberia na liquidação, o credor pode se opor ao tramento inferior e evitar a confirmação do plano. Para determinar se há respeito ao best-interest, caberá ao tribunal comparar hipoteticamente (i) qual seria o valor arrecadado com a liquidação do devedor, (ii) quanto o credor receberia nesse cenário, e (iii) qual o valor de pagamento que lhe está sendo proposto. Nesses casos, além da análise das informações financeiras prestadas pelo proponente do plano, pode ser necessária perícia da situação financeira do devedor. Ademais, se o plano previr o diferimento do pagamento, será necessário aplicar taxa de desconto para trazer o crédito a valor presente, o que enseja discussões jurisprudenciais a respeito de qual taxa de desconto é adequada. ${ }^{358}$

Caso o plano atenda ao teste de best-interest e aos outros quatorze requisitos legais previstos no §1129(a) do BC - entre os quais ser considerado viável (feasible) pelo magistrado (BC, §1129(a)(11)) - mas não tenha sido aprovado por todas as classes, será possível sua aprovação pelo mencionado mecanismo de cram down, desde que ao menos uma classe de credores afetados pelo plano o tenha aceito. Será, então, necessário que o plano apresentado atenda a dois requisitos adicionais: o de que não promova discriminação injustificada (unfair discrimination) e o de que respeite a prioridade falimentar (seja considerado fair and equitable).

A proibição de discriminação injustificada $(B C, \S 1129(b)(1))$ não diz respeito ao tratamento entre os credores de uma determinada classe, pois, como já se esclareceu, o tratamento intra classe deve ser estritamente igualitário, exceto se o credor prejudicado aceitar tratamento diferenciado. É possível, todavia, que créditos com mesma prioridade falimentar sejam separados em classes diversas. Por exemplo, créditos quirografários detidos por bancos podem ser separados de créditos quirografários detidos por fornecedores. ${ }^{359}$ Entre essas classes de mesma prioridade poderá haver tratamento diferenciado, mas é necessário justificá-lo. ${ }^{360}$ A necessidade de posterior cooperação do

\footnotetext{
$357 \quad I d ., \S 11.26$, p. 1136: "All creditors and interest holders thus posses a limited veto power over the terms of a chapter 11 plan".

$358 \quad I d ., \S 11.26$, p. 1138.

359 ISAAC M. PACHULSKI, "The Cram Down and Valuation under Chapter 11 of the Bankruptcy Code", in N. C. L. Rev., vol. 58, 1980, pp. 925-965, p. 930.

360 Charles J. TABB, The Law of Bankruptcy, cit., §11.33, p. 1171.
} 
fornecedor, por exemplo, poderia ser invocada como justificativa para o tratamento diferenciado. ${ }^{361}$

Certamente, contudo, o mais polêmico requisito para a superação do veto de uma classe de credores é a necessidade de respeito à prioridade falimentar, por meio do teste de tratamento fair and equitable $(\mathrm{BC}, \S 1129(\mathrm{~b})(1))$. Essa regra remonta às origens da reorganization norte-americana.

A reorganization foi um procedimento criado pela prática norte-americana para promover a reestruturação do capital das ferrovias, que entraram sistematicamente em crise na segunda metade do século XIX. ${ }^{362}$ Era essencial que essas empresas não fossem desmanteladas e continuassem a ser operadas. Para concretizar essa finalidade, a prática se utilizou do antigo instituto do equity receivership - que permitia a continuidade da operação empresarial, ao impor a suspensão de ações e execuções. Quando a ferrovia deixava de promover algum pagamento, um dos credores solicitava que fosse aplicado o regime de equity receivership e que fosse indicado um administrador (receiver), que tinha por objetivo continuar operando a ferrovia em crise. ${ }^{363} \mathrm{Na}$ sequência, pelo processo de equity receivership, os ativos deveriam ser vendidos conjuntamente, se possível. Desse "leilão" aberto à concorrência, contudo, participavam efetivamente apenas os próprios credores, que poderiam pagar pelos ativos sem injetar novos recursos, convertendo seus créditos. ${ }^{364}$ Criava-se, então, uma nova companhia que tinha seu capital distribuído aos credores.

Em geral, as ferrovias tinham como principais credores investidores estrangeiros, sobretudo europeus, clientes de bancos de investimento norte-americanos. ${ }^{365}$ Para esses bancos, era essencial a garantia de sua reputação, já que tinham intermediado emissões de empresas naquele momento em crise. ${ }^{366}$ Entretanto, os credores em geral não tinham condições de ir aos Estados Unidos para fazer valer seus direitos. Por conta disso, os

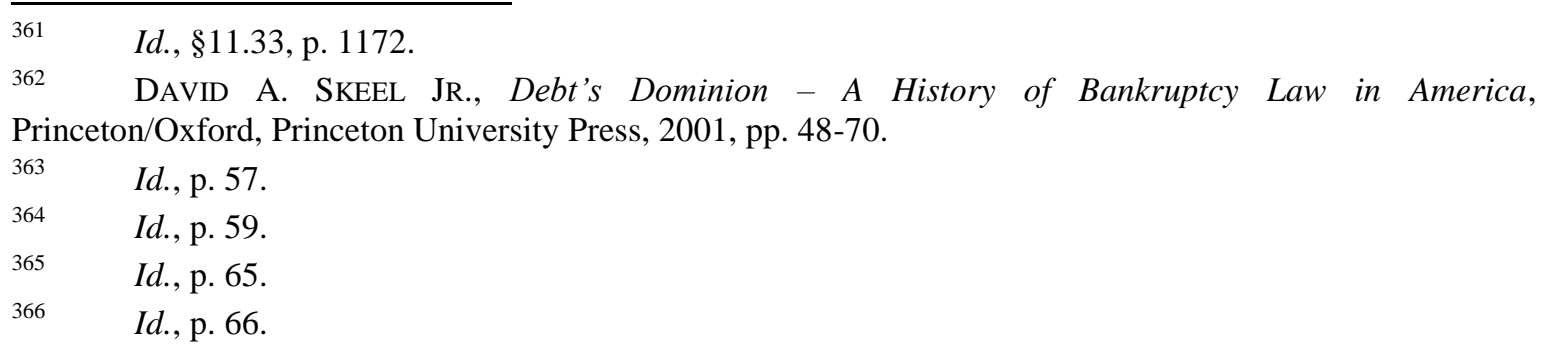


bancos formavam comitês para representar os credores e solicitavam a estes o depósito de seus títulos e a concessão de procuração para que os bancos os representassem perante o juízo concursal. Os bancos detinham, então, um poder de negociação muito superior ao dos demais credores, desorganizados, e faziam valer tal superioridade. Em geral, o capital das empresas reorganizadas passava a ser de titularidade apenas dos credores com garantia e do devedor, ao passo que os credores sem garantia recebiam valor ínfimo. ${ }^{367}$

A origem da regra do tratamento fair and equitable está ligada à repressão a esse conluio entre credores garantidos e acionistas, considerado espúrio. Se o interesse público na manutenção das ferrovias justificou certa leniência em relação aos frequentes desrespeitos à hierarquia concursal, com o fim da era das reorganizations das ferrovias, a jurisprudência norte-americana passou a ser mais restritiva em relação às técnicas colusivas que vinham sendo empregadas. $^{368}$

Na reorganização da Northern Pacific Railway, os credores garantidos permaneceram com todo o capital, mas, para incentivar a manutenção da administração, deram aos antigos acionistas participação no capital social da sociedade reorganizada. Boyd, um credor quirografário, não aceitou essa situação. Em seu ponto de vista, os antigos acionistas não poderiam participar do capital da empresa reorganizada, pois os credores quirografários deveriam ter satisfação prioritária. A Supreme Court aceitou o argumento, enunciando o princípio do que uma reorganização não poderia ser realizada em desrespeito à ordem de preferências entre os credores e de que um detentor de participação societária não poderia receber nenhum valor antes da plena satisfação dos credores quirografários. ${ }^{369}$

Em 1934, foi editado o Bankruptcy Act, que, pela primeira vez, previu legislativamente a figura da reorganization e determinou, em seu $\S 77(\mathrm{f})(1)$, que o juiz apenas estaria autorizado a aprovar planos que oferecessem tratamento fair and equitable para os credores. $^{370}$

\footnotetext{
$367 \quad$ Id., p. 67.

368 DAVID A. SKEEL JR., Debt's Dominion - A History of Bankruptcy Law in America, cit., p. 105.

$369 \quad$ Northern Pacific Railway Co. v. Boyd, 228 U.S. 482 (1913).

370 ChARLES J. TABB, The Law of Bankruptcy, cit., §11.31, p. 1155.
} 
Coube a William Douglas, juiz da Supreme Court e autor de um profundo estudo sobre as ilegalidades cometidas nos processos falimentares, ${ }^{371}$ esclarecer o significado dessa expressão. ${ }^{372}$ No julgamento de Case v. Los Angeles Lumber Products Co., Ltd., decidiu-se que a expressão, apesar de nova, reafirmava a jurisprudência do caso Northern Pacific Railway - um plano só pode ser considerado fair and equitable se respeita a regra de absolute priority, segundo a qual os titulares de participação societária somente podem participar do capital da companhia reorganizada depois que todos os credores sejam completamente satisfeitos. ${ }^{373}$ Desenvolveu-se, contudo, uma exceção à regra, denominada new value exception. Segundo essa exceção, um acionista poderia obter alguma participação societária na companhia reorganizada, se fornecesse uma contribuição em dinheiro, ou equivante a dinheiro. ${ }^{374}$ Em decisões posteriores, a new value exception tomou contornos mais rígidos. Contribuições com experiência, trabalho ou conhecimento específico pelos antigos acionistas não são admitidas, por não serem passíveis de apreciação pecuniária, ${ }^{375} \mathrm{e}$, caso o antigo sócio forneça nova quantia monetária em troca de sua participação, deverá fazê-lo em igualdade de condições e em livre concorrência com terceiros que busquem obter a mesma participação. ${ }^{376}$

No Bankruptcy Act de 1934, a regra fair and equitable precisava ser observada sempre, ou seja, nunca poderia haver desrespeito à ordem de prioridade falimentar. Segundo Tabb, porém, a aplicação da regra era considerada um "pesadelo". ${ }^{377}$ Era sempre necessário determinar o valor da empresa na reorganization, para compará-lo com o valor de liquidação, e determinar se os credores recebiam tratamento superior ao que receberiam na

\footnotetext{
371 DAVID A. SKeEl JR., Debt's Dominion - A History of Bankruptcy Law in America, cit., pp. 109-113.

372 Note-se, portanto, que a despeito do uso de conceitos abertos como "fair" e "equitable", a vinculação a precedentes jurisprudenciais torna seu significado bastante bem delimitado por meio de sua filiação histórica. Ademais, no $\$ 1129(\mathrm{~b})(2)(\mathrm{A})$, (B) e (C) do BC há específica descrição do que seja necessário para que um plano seja considerado fair and equitable ("for the purpose of this subsection, the condition that a plan be fair and equitable with respect to a class includes the following requirements: [...] \$1129(b)(2)). Discorda-se, portanto, com a devida vênia, da descrição do sistema de cram down norteamericano formulada por ALBERTO CAMIÑA MOREIRA, para quem: “[n]os EUA, a lei em relação ao cram down diz que o plano deve ser justo, eqüitativo e não discriminatório. Quem fala em plano justo e eqüitativo usa de conceitos indeterminados, amplos, genéricos, que dão margem à mais ampla interpretação." ("Poderes da assembléia de credores, do juiz e atividade do Ministério Pùblico", in LuIZ FERNANDO V. DE PAIVA (coord.), Direito Falimentar e a Nova Lei de Falências e Recuperação de Empresas, São Paulo, Quartier Latin, 2005, pp. 247-274, pp. 258-259).

$373 \quad$ Case v. Los Angeles Lumber Products Co., Ltd., 308 U.S. 106 (1939), p. 107.

$374 \quad$ Id.

$375 \quad$ Norwest Bank Worthington v. Ahlers, 485 U.S. 197 (1988).

376 Bank of America National Trust and Savings Association v. 203 North LaSalle Street Partnership, 526 U.S. 434 (1999).

377 ChARLES J. TABB, The Law of Bankruptcy, cit., §11.31, p. 1156.
} 
liquidation. Mas a avaliação era extremamente subjetiva, realizada pelo sistema de fluxo de caixa descontado, em que a determinação do fluxo futuro e da taxa de desconto eram realizadas de forma quase arbitrária. ${ }^{378}$ Por conta disso, em 1978, durante a tramitação do Bankruptcy Code, o Congresso decidiu flexibilizar a regra, afirmando que o cumprimento da regra de prioridade absoluta somente seria analisado se houvesse uma classe dissidente. Além disso, somente seria analisado o cumprimento da regra de prioridade da classe dissidente para baixo, ou seja, se credores com preferência superior aceitassem receber menos do que na falência, não haveria necessidade de intervenção judicial. ${ }^{379}$

Formou-se, com isso, a atual configuração da regra de absolute priority, que ocorre quando há respeito ao requisito de tratamento fair and equitable aos credores. A regra tem aplicação diversa conforme se trate da superação do veto oposto por uma classe de credores com garantia, sem garantia, ou titular de participação societária. ${ }^{380}$ O objetivo da regra é assegurar que não seja superado o veto de nenhuma classe sem respeito à ordem de prioridade falimentar. Para o credores garantido, o cram down exige que o credor mantenha sua garantia sobre o bem, mesmo que o bem seja alienado a terceiros e que o credor receba pagamento de valor correspondente a seu crédito de forma diferida; ou, caso o bem seja vendido livre de garantia, o credor subrogue-se no valor da venda; ou que o credor receba valor que seja considerado indubitavelmente equivalente ao valor de seu crédito garantido $(\mathrm{BC}, \S 1129(\mathrm{~b})(2)(\mathrm{A}))$. Para o credor quirografário, o necessário é que receba um valor equivalente ao de seu crédito; ou que nenhum credor de classe inferior, ou titular de participação societária, receba qualquer valor por conta de seu crédito (BC, $\S 1129(\mathrm{~b})(2)(\mathrm{B})$ ). Para o titular de participação societária, é necessário o recebimento de valor equivalente a preço de amortização, caso existente, ou que nenhum titular de participação societária de classe inferior receba nenhum valor (BC, §1129(b)(2)(C)).

A descrição da regra gera estranhamento. Ao jurista brasileiro, é difícil compreender que sejam aprovados planos de reorganization em que os sócios do devedor não fiquem com

\footnotetext{
$378 \quad$ Id., $\$ 11.31$, p. 1157.

$379 \quad$ Id., $\$ 11.31$, p. 1159.

$380 \quad$ Para detalhes sobre as diferentes regras aplicáveis, cf. RICHARD MALOY, “A primer on cram down how and why it works", in St. Thomas L. Rev., vol. 16, 2003, pp. 1-57, pp. 14-43; KENNETH N. KLEE, "All You Ever Wanted to Know About Cram Down Under the New Bankruptcy Code", in Am. Bankr. L. J., vol. 53, 1979, pp. 133-171; KenNeTH N. KleE, “Cram down II”, in Am. Bankr. L. J., vol. 64, 1990, pp. 229-244. Para estudo comparatístico, cf. BURKHARD FASSBACH, Die cram down power des amerikanischen Konkursgerichtes im Reorganisationsverfahren nach Chapter 11 des Bankruptcy Code - Vorbild für das Obstruktionsverbot in der deutschen Insolvenzordnung, Frankfurt a.M., Peter Lang, 1997.
} 
nenhuma participação societária. A constante avaliação do valor da empresa tampouco parece medida que possa ser implementada com facilidade na prática.

Efetivamente, a leitura da regra, descontextualizada de sua aplicação prática, pouco indica a respeito da função efetivamente exercida pelo cram down no direito recuperacional norte-americano. O cram down, a um só tempo, evita comportamentos de bloqueio injustificado e protege a posição do credor contra desrespeitos graves a sua prioridade falimentar.

Caso o credor não aprove o plano, mas o proponente do plano insista em sua aprovação por meio do cram down, será necessário que o juiz arbitre o valor de liquidação e de reorganização da empresa em crise, um procedimento moroso, caro e, sobretudo, incerto. Enquanto a avaliação de empresas sadias já envolve grande nível de subjetividade, na avaliação de empresa em crise fatores adicionais dificultam a tarefa. Há dois principais métodos utilizados para a avaliação de empresas: fluxo de caixa descontado e comparação por múltiplos. Pelo critério de fluxo de caixa descontado, busca-se prever qual será o faturamento futuro da empresa e trazê-lo a valor presente pela aplicação de um fator de desconto. Mas o faturamento passado da empresa a levou, justamente, à crise. Por conta disso, é difícil adotá-lo como referencial. ${ }^{381}$ Quando se calcula o valor da empresa com um plano de reorganização, ademais, será necessário incluir no cálculo os efeitos de medidas de saneamento previstas no plano, mas ainda não implementadas. ${ }^{382} \mathrm{Na}$ comparação por múltiplos, por sua vez, o valor da empresa é obtido por meio de uma comparação com outras empresas atuantes no mesmo mercado, o que pode ser praticamente inútil para empresas de pequeno e de médio portes, pela ausência de parâmetros válidos de comparação. ${ }^{383}$ Além disso, em procedimentos de reorganization, se o juiz comete erros de avaliação da empresa, não sofrerá consequências econômicas. ${ }^{384} \mathrm{O}$ resultado é que, em geral, as avaliações judiciais são pouco conservadoras ${ }^{385} \mathrm{e}$, por vezes, resultado de um

\footnotetext{
381 RALPH A. PEEPLES, "Staying in: Chapter 11, Close Corporations and the Absolute Priority Rule", in Am. Bankr. L. J., vol. 63, 1989, pp. 65-108, p. 86.

382 CHRISTIAN HERWEG, Das Obstruktionsverbot bei der Unternehmensanierung, Köln, RWS Kommunikationsforum, 2004, p. 128.

$383 \quad$ Id., p. 131.

384 HORST EIDENMÜLLER, Unternehmenssanierung zwischen Markt und Gesetz, cit., p. 89.

385 Id., p. 89.
} 
cálculo reverso: o juiz considerada determinada composição acionária na empresa reorganizada como adequada e avalia a empresa para alcançar esse resultado. ${ }^{386}$

Por conta disso, o cram down exerce a função de ameaça latente, um fator de barganha que permite a superação judicial de impasses, mas traz prejuízos - custos e demora - a todos caso seja efetivamente utilizado. ${ }^{387} \mathrm{O}$ mote do sistema de reorganização previsto no Bankruptcy Code é o de "evitar a avaliação por meio da negociação". ${ }^{388}$ A utilização efetiva do cram down, porém, é diminuta. Em um clássico estudo de 43 casos de reorganization de grandes empresas, que analisou planos aprovados por um total de 377 classes, constatou-se que, entre essas classes, apenas $3(0,8 \%)$ tiveram seu veto superado por meio do procedimento de cram down. ${ }^{389}$

Seria possível imaginar que o baixo nível de contestação judicial estaria ligado a uma internalização da regra de prioridade absoluta nos planos, e estivesse associado a um alto respeito à prioridade. Mas estudos empíricos comprovaram que não é isso o que geralmente ocorre. Foram constatados desvios frequentes da regra de prioridade falimentar. ${ }^{390}$ Entre as diversas explicações formuladas para esse desvio, afirma-se que um fator relevante seria o fato de que o devedor pudesse manter-se à frente dos negócios da empresa em crise durante o procedimento, o que pressionaria os credores a alcançarem uma solução célere, para diminuir o risco de o devedor dissipar patrimônio. ${ }^{391}$ Atualmente,

386 O que já era apontado sob a vigência do Bankruptcy Act (HENRY B. GARDNER, "SEC and valuation under Chapter X”, in U. Pa. L. Rev., vol. 91, 1943, pp. 440-465, p. 453), e ainda hoje ocorre (CHARLES J. TABB, The Law of Bankruptcy, cit., §11.31, p. 1157).

387 Kenneth N. KLEE, "All You Ever Wanted to Know About Cram Down Under the New Bankruptcy Code", cit., p. 145; Richard F. BROUdE, "Cram Down and Chapter 11 of the Bankruptcy Code: the Settlement Imperative", in Bus. Law., vol. 39, 1984, pp. 441-454, p. 454.

388 Chaim J. Fortgang, ThOMAS M. MAYER, "Valuation in Bankruptcy", in UCLA L. Rev., vol. 32, 1985, pp. 1061-1132, pp. 1105-1107.

389 LYNN M. LOPUCKI, WILLIAM C. WhITFORD, "Bargaining over Equity's Share in the Bankruptcy Reorganization of Large, Publicly Held Companies”, in U. Pa. L. Rev., vol. 139, 1990, pp. 125-196, p. 141.

390 Allan C. Eberhart, William T. Moore, Rodney L. Roenfeldt, "Security Pricing and Deviations from the Absolute Priority Rule in Bankruptcy", in J. Fin., vol. 45, 1990, pp. 1457-1469; JULIAN R. Franks, WALTER N. TOROUS, "An Empirical Investigation of U.S. Firms in Reorganization", in J. Fin., vol. 44, 1989, pp. 747-769; Douglas G. BAIRD, DONALD S. BERnSTEIN, “Absolute Priority, Valuation Uncertainty, and the Reorganization Bargain”, in Yale L. J., vol. 115, 2006, pp. 1930-1970.

391 JULIAN R. FrankS, WALTER N. TOROUS, "An Empirical Investigation of U.S. Firms in Reorganization", cit., p. 748. Em um outro estudo, de natureza empírica, foram entrevistados diversos advogados falencistas que atuavam em defesa tanto de devedores como de credores; os profissionais foram questionados quanto à justificativa para explicar por que os titulares de participação societária permaneciam nessa posição após a reorganization. Não foi obtido um posicionamento unânime. Seis razões principais, contudo, foram fornecidas: (i) economia de custos judiciais, pois, caso houvesse rejeição, o devedor poderia litigar contra o credor dissidente, e os respectivos custos recairiam sobre a massa; (ii) redução de demora e de 
argumenta-se que o principal fator que permite que titulares de participação societária tomem parte no capital da empresa emergente da reorganization seja o fato de que avaliações são incertas, caras e demoradas. ${ }^{392}$

Percebe-se, com isso, que o cram down é instituto que se insere em um sistema complexo e peculiar. Sua transposição para outro sistema, sem o devido acompanhamento por contrapesos do direito concursal norte-americano, pode fazer com que o instituto ganhe outra conformação. Foi o que ocorreu na Alemanha.

\subsubsection{AlemanHA}

A Insolvenzordnung conta com regras semelhantes às norte-americanas, mas que, inseridas em contexto diverso, têm função e atuação também diversas. Na legislação alemã, o objetivo único do procedimento concursal empresarial é a satisfação coletiva dos credores $(\mathrm{InsO}, \S 1)$.

É possível que, para a liquidação dos ativos, seja preparado plano de insolvência (Insolvenzplan), que preveja a adoção de instrumentos diversos daqueles utilizados na liquidação ordinária e que podem incluir a preservação da empresa ( InsO, §217). O plano pode ser proposto pelo devedor ou pelo administrador judicial (InsO, §218) e deverá ser votado pelos credores, divididos em classes (InsO, §222). Para a formação das classes, os credores devem ser obrigatoriamente separados de acordo com a natureza do crédito (InsO, $\S 222$, Abs. 1) e, depois, podem ser novamente divididos em classes de participantes com interesses econômicos comuns (InsO, §222, Abs. 2). A deliberação sobre o plano ocorre de forma separada em cada classe (InsO, §243), e a aprovação em cada classe depende da obtenção de maioria por créditos e por cabeça (InsO, §244, Abs. 1, Nr. 1 e 2). Para a aprovação do plano, todas as classes devem aceitar o plano (InsO, §244, Abs. 1).

incerteza no processo, que pode reduzir a capacidade de recuperação da empresa; (iii) o fato de que a administração utilizava sua superioridade informacional para privilegiar os antigos acionistas; (iv) o fato de que não era necessário distribuir tanto capital para obter o consenso de antigos sócios; (v) a finalidade de aumentar a liquidez de ações da companhia reorganizada; e (vi) a finalidade de transmitir uma sensação de paz entre devedor e credores, que daria maior crédito à empresa reorganizada na negociação com terceiros (Lynn M. LoPuCKi e William C. WhitFord, "Preemptive Cram Down”, in Am. Bankr. L. J., vol. 65, 1991, pp. 625-647, pp. 628-629).

392 Douglas G. BAIRD, Donald S. BERnSteIn, "Absolute Priority, Valuation Uncertainty, and the Reorganization Bargain”, cit., pp. 1952-1963. 
Caso essa maioria não seja obtida, é possível a aprovação do plano por meio de sistema denominado proibição de obstrução (Obstruktionsverbot). A exposição de motivos da Insolvenzordung fundamenta a adoção da regra de proibição de obstrução deste modo: "quando uma classe de credores recusa seu consentimento ao plano, a recusa pode ser abusiva. Assim, não há um motivo racional para que uma classe de credores contrarie um plano desejado por outros credores se o plano não a situa em posição pior à que estaria sem o plano, e, ademais, a classe não é discriminada indevidamente em relação às demais classes, obtendo parte adequada do valor adicional gerado pelo plano. Esse pensamento, desenvolvido nos Estados Unidos, está refletido na lei." ${ }^{393}$

Essa proibição de obstrução, segundo Dirk Schulz, é inspirada no sistema norte-americano, mas não era desconhecida no direito alemão, em que se considera que o dever societário de lealdade pode impor aos acionistas deveres de voto positivo (positive Stimmpflichten). ${ }^{394} \mathrm{~A}$ proibição de obstrução, afirma Schulz, "busca evitar que certas partes envolvidas no procedimento bloqueiem a execução de um procedimento de plano de insolvência por conta de interesses estanhos ou pelo exercício abusivo do direito de voto". 395

Entretanto, diferentemente do que ocorre nos Estados Unidos, não basta que ao menos uma classe tenha aprovado o plano para que o mecanismo atue. ${ }^{396}$ É necessário que ao menos metade das classes tenha aprovado o plano (InsO, §245, Abs. 1, Nr.3). Para a superação do veto em cada classe, é preciso que os integrantes da classe não sejam situados em situação inferior à que provavelmente estariam sem o plano (InsO, §245, Abs. 1, Nr.1) e recebam parte adequada do valor econômico que será distribuído às classes (InsO, §245, Abs. 1, Nr.2). Para que seja atendido o critério da participação adequada no valor econômico, é

393 DEUSTSCHER BUNDESTAG, Gesetzentwurf der Bundesregierung: Entwurf einer Insolvenzordnung (InsO), cit., p. 208: "Wenn eine Abstimmungsgruppe die Zustimmung zum Plan verweigert, kann in dieser Verweigerung ein Missbrauch liegen. So besteht kein vernünftiger Grund für eine Gruppe von Gläubigern, einem von anderen Gläubigern gewünschten Plan zu widersprechen, wenn die Gruppe durch den Plan wirtschaftlich nicht schlechter gestellt wird, als sie ohne einen Plan stünde, und wenn zusätzlich gewährleistet ist, dass die Gruppe bei der Verteilung des durch den Plan realisierten Mehrwertes im Verhältnis zu anderen Gruppen nicht unbillig benachteiligt wird. Dieser Gedanke, der im Insolvenzrecht der Vereinigten Staaten von Amerika entwickelt ist, wird in Absatz 1 niedergelegt."

394 DIRK SCHULZ, Treuepflichten unter Insolvenzgläubigern, cit., p. 9.

395 Id., p. 79: "Das Obstruktionsverbot des $\$ 245$ InsO soll verhindern, dass einzelne Beteiligte aufgrund sachfremder Interessen durch missbräuchliches Abstimmungsverhalten die Durchführung des Insolvenzplanverfahrens blockieren [...]".

396 CHRISTIAN HERWEG aponta para críticas doutrinárias a esse maior rigor da legislação alemã em relação a sua análoga norte-americana (Das Obstruktionsverbot bei der Unternehmensanierung, cit., pp. 8889). 
necessário que nenhum credor receba mais do que o valor de seu crédito (InsO, §245, Abs. 2, Nr.1), não haja tratamento diferenciado entre credores com mesma prioridade falimentar (InsO, §245, Abs. 2, Nr.3) e que nenhum credor com prioridade falimentar inferior, nem o devedor, nem os titulares de participação societária recebam nenhum valor (InsO, §245, Abs. 2, Nr.2). Soma-se a essa proteção a possibilidade de que qualquer credor se oponha à aprovação de um plano, se o plano situá-lo em condições inferiores à que estaria sem o plano (InsO, §251, Abs. 1, Nr. 2), em regra denominada "proteção da minoria" (Minderheitenschutz), que corresponde ao teste norte-americano de best-interest.

Caso se pretenda a aprovação de plano por meio do mecanismo de proibição de obstrução, será necessário também calcular o valor do devedor reorganizado sob o plano e compará-lo com seu valor de liquidação, o que exige complexos exercícios de prognose, ${ }^{397}$ ainda que o cálculo não tenha de ser exato, e a lei se contente com um juízo de probabilidade. ${ }^{398} \mathrm{Da}$ mesma forma que no direito norte-americano, defende-se que os sócios apenas possam manter sua participação societária em um plano aprovado pela via da proibição de obstrução se fornecerem novos recursos financeiros em pecúnia. ${ }^{399}$ Em teoria, portanto, a regra alemã é praticamente a mesma da legislação norte-americana. Entretanto, outros aspectos do sistema concursal alteram a forma de atuação da regra.

$\mathrm{Na}$ Alemanha, o devedor somente pode ser mantido à frente das operações da empresa em crise se os credores assim determinarem, tornando essa possibilidade praticamente irrelevante do ponto de vista prático ${ }^{400}$ - é utilizada em menos de $1 \%$ dos $\operatorname{casos}^{401}$-, razão pela qual é objeto de críticas e propostas de reforma. ${ }^{402}$ Ademais, os credores, sobretudo garantidos, exercem grande poder pela possibilidade de apontar administrador judicial que

\footnotetext{
397 HORST EIDENMÜLLER, "Prognoseentscheidung im Insolvenzplanverfahren: Verfahrenslähmung durch Minderheitenschutz?", in NJW, n. 25, 1999, pp. 1937-1939; STEFAN SMID, "Die 'cram down power' des deutschen Insolvenzgerichts", in InVo, n. 1, 2000, pp. 1-9, p. 6.

398 CARSTEN JUNGMANN, "Schlechterstellungsverbote im Insolvenzplanverfahren - Zum Verhältnis und Verständnis der $\S \S 245$ und 251 InsO”, in KTS, n. 2, 2006, pp. 135-150, p. 141.

$399 \quad$ ARNE WitTig, "Obstruktionsverbot und Cram Down - $\$ 245$ InsO im Lichte der LaSalle Street Entscheidung des U.S. Supreme Court v. 3.5.1999, in ZInsO, n. 7, 1999, pp. 373-379, pp. 378-379.

$400 \quad$ HORST EIDENMÜLLER, "Regulierungswettbewerb im Unternehmensinsolvenzrecht: Ergebnisse einer empirischen Untersuchung”, in NZI, n. 14, 2010, pp. 545-551, p. 550.

401 MICHAEL JAFFÉ, "Die Eigenverwaltung im System des Restrukturierungsrechts", in ZHR, vol. 175, 2011, pp. 38-54, p. 38.

402 HORST EIDENMÜLLER, "Die Eigenverwaltung im System des Restrukturierungsrechts", in ZHR, vol. 175, 2011, pp. 11-37.
} 
lhes seja leal e beneficie seus interesses, ${ }^{403}$ bem como a de determinar o encerramento das operações do devedor (InsO, §157).

Nesse contexto, a proibição de obstrução (o "cram down alemão") apresenta acentuadas diferenças em relação a seu congênere norte-americano. Enquanto o cram down norteamericano é um instrumento utilizado por iniciativa do devedor, e em seu interesse, a proibição de obstrução ocorre ex officio pelo magistrado. ${ }^{404}$ Nos Estados Unidos, a avaliação da empresa exigida pelo sistema de cram down irá onerar o devedor, diminuindo o total de recursos disponíveis à satisfação dos credores; na Alemanha, esses custos não são incorridos pela massa, mas pelo participante que apresenta o plano e busca aprová-lo pela via da proibição de obstrução. ${ }^{405}$ Soma-se a isso a diferença cultural existente entre os países, sendo os Estados Unidos mais orientados à proteção do devedor quando comparados com a Alemanha. ${ }^{406}$

Apesar de semelhantes, portanto, as regras têm função e atuação diversas. Enquanto nos Estados Unidos a regra de cram down serve como fator de pressão para o atingimento de consenso, na Alemanha atua como fator de forte proteção aos credores.

\subsubsection{CRÍTICAS}

Há críticas doutrinárias a três aspectos centrais do mecanismo de cram down e à preservação rígida da regra de prioridade absoluta (presentes tanto no direito norteamericano quanto no direito alemão). A primeira crítica reporta-se à legitimidade e à conveniência de garantir que, em uma reorganização, o credor com prioridade concursal inferior apenas obtenha alguma satisfação se o credor de prioridade concursal superior for plenamente satisfeito. Discute-se, portanto, a prioridade absoluta entre os credores.

A segunda crítica diz respeito à prioridade entre credores e titulares de participação societária. Há quem questione a conveniência de apenas permitir que o devedor ou os

\footnotetext{
403 NATHALIE MARTIN, "The role of history and culture in developing bankruptcy and insolvency systems: the perils of legal transplantation”, in B. C. Int'l \& Comp. L. Rev., vol. 28, 2005, pp. 1-77, p. 49.

404 STEFAN SMID, “Zum 'Obstruktionsverbot' - \$245 InsO”, in InVo, n. 12, 1996, pp. 314-320, p. 316.

$405 \quad$ Id., p. 317.

406 CARSTEN JUNGMANN, "Schlechterstellungsverbote im Insolvenzplanverfahren - Zum Verhältnis und Verständnis der $\S \S 245$ und 251 InsO”, cit., p. 140.
} 
sócios da sociedade devedora recebam algum valor sob o plano de reorganização se todos os credores tiverem sido plenamente satisfeitos ou se fornecerem nova contribuição pecuniária.

A terceira crítica diz respeito à necessidade de avaliação da empresa e busca desenvolver propostas para - utilizando mecanismos de mercado - oferecer soluções que preservem a ordem de recebimentos na falência, mas prescindam da necessidade de avaliação.

\subsection{CRÍTICA À PRIORIDADE ENTRE CREDORES}

Desde o final da década de 1980, a doutrina norte-americana vem se debatendo acerca dos fundamentos normativos que justificam as prioridades concursais. Por que é válido "um acordo entre $\mathrm{A}$ e $\mathrm{B}$, para que $\mathrm{C}$ não receba nada" ${ }^{407}$

Há três principais correntes doutrinárias sobre o assunto, embora, até hoje, não se tenha obtido nenhum consenso. $^{408}$ A primeira corrente defende que garantias são economicamente eficientes. Garantias reduzem riscos e, com isso, diminuem o custo do crédito e aumentam sua disponibilidade. ${ }^{409}$ Se o credor não receber garantias para seu crédito, terá de gastar tempo e dinheiro monitorando as atividades do devedor, ${ }^{410}$ seja pela celebração de cláusulas contratuais de proteção (covenants), seja pela análise de sua situação financeira. Com a concessão de garantias, os custos de de monitoramento diminuem, pois o credor apenas tem uma preocupação, restrita à manutenção de sua garantia. $^{411}$

Uma segunda corrente concebe a concessão de garantias como um minus em relação ao poder de alienar um bem. Considerando que o direito de propriedade engloba o poder de

\footnotetext{
407 LYNN M. LoPUCKI, “The Unsecured Creditor’s Bargain”, in Va. L. Rev., vol. 80, 1994, pp. 18871965, p. 1899.

408 Para um resumo do extenso debate sobre o assunto, cf. BRAIN M. MCCALL, "It's Just Secured Credit! The Natural Law Case in Defense of Some Forms of Secured Credit", in Ind. L. Rev., vol. 43, 2009, pp. 7-44, pp. 9-16.

409 DAVID G. CARLSON, "On the Efficiency of Secured Lending", in Va. L. Rev., vol. 80, 1994, pp. 2179-2213.

410 F.H. BucKley, “The Bankruptcy Priority Puzzle”, in Va. L. Rev., vol. 72, 1986, pp. 1393-1470, p. 1469.

411 Thomas H. JACKSON, ANTHONy T. KRONMAN, "Secured Financing and Priorities among Creditors", in Yale L. J., vol. 88, 1979, pp. 1143-1182, pp. 1149-1158.
} 
usar, fruir e dispor de um bem e que se reconhecem a liberdade contratual e o direito à propriedade, pode-se fundamentar a liberdade para conferir garantias da mesma forma que é fundamentada normativamente a liberdade de contratar: pela crença de que, ao conferir liberdade aos particulares, os recursos seriam alocados àqueles que maximizam o uso dessa prerrogativa. $^{412}$

Já a terceira linha doutrinária refuta ambos os posicionamentos e aponta para as externalidades geradas pela concessão de garantias. Ao constituir uma garantia, o devedor altera a prioridade concursal de credores que não consentiram com essa garantia ou não tinham condições de conhecê-la. ${ }^{413}$ Ao privilegiar os credores garantidos, a lei direciona os recursos escassos da empresa em crise para a satisfação de credores voluntários, com melhor condição de diversificar sua exposição financeira, em detrimento de credores involuntários, que não têm a mesma condição de se proteger. ${ }^{414}$ Conquanto fosse possível defender que, em um mercado perfeito, todos os credores ajustariam a taxa de juros cobrada pelo seu crédito à prioridade que lhes foi conferida, há, na realidade, credores "não ajustantes", como credores involuntários (vítimas de danos), e credores voluntários que não conseguem impor suas condições de crédito pelo seu reduzido poder de negociação (é o caso de fornecedores, empregados e titulares de créditos de pequena monta). Ao conferir uma garantia a um credor, o devedor transferiria valores desses credores "não ajustantes" para o credor com garantia. ${ }^{415}$ Critica-se, ademais, o argumento a fortiori segundo o qual o credor que pode alienar seu bem sempre poderia instituir garantia sobre ele. Isso porque, ao conferir garantia, o devedor rearranja a ordem hierárquica entre seus respectivos credores na hipótese de sua falência. Com isso, em verdade, não aliena um bem seu, mas altera a posição jurídica relativa de seus credores. ${ }^{416}$

\footnotetext{
412 STEVEN L. HARRIS, Charles W. MOONEY JR., “A Property-Based Theory of Security Interests: Taking Debtors' Choices Seriously”, in Va. L. Rev., vol. 80, 1994, pp. 2021-2072, pp. 2047-2053.

413 LYNN M. LOPUCKI, “The Unsecured Creditor’s Bargain”, cit., p. 1963.

414 Elizabeth WARren, "Making Policy with Imperfect Information: the Article 9 Full Priority Debates", in Cornell L. Rev., vol. 82, 1997, pp. 1373-1395, p. 1389.

415 Lucian A. Bebchuk, Jesse M. Fried, "The Uneasy Case for the Priority of Secured Claims in Bankruptcy”, in Yale L. J., vol. 105, 1996, pp. 857-934, p. 895.

416 MORITZ BRINKMANN, "The Position of Secured Creditors in Insolvency", in HoRST EIDENMÜLLER, EVA-MARIA KIENINGER (orgs.), The Future of Secured Credit in Europe - European Company and Financial Law Review, Special Volume 2, 2008, pp. 248-272, pp. 254.
} 
Pode-se afirmar que o debate fracassou em alterar a legislação para que garantias concursais fossem extintas. ${ }^{417}$ Entretanto, poderia lançar bases para o questionamento acerca da necessidade de respeito à prioridade absoluta em procedimentos concursais.

\subsection{CRÍTICA À PRIORIDADE ENTRE CREDORES E DEVEDOR}

A regra de prioridade absoluta, vigente nos Estados Unidos e na Alemanha, como se viu, determina que não pode haver cram down se o devedor, ou sócios da sociedade devedora, receberem algum valor ou participarem do capital social da companhia reorganizada, a menos que todos os credores tenham sido satisfeitos. Essa regra é objeto de críticas.

A regra da prioridade absoluta não era observada na prática das primeiras reorganizações de ferrovias norte-americanas. Em geral, o capital da companhia reorganizada era dividido prioritariamente entre os credores garantidos, representados por banqueiros de investimento, e os antigos sócios. ${ }^{418}$ Durante o período do New Deal, essa prática foi criticada, por prejudicar injustamente os credores sem garantia. Por conta disso, o Chandler Act proibiu a violação da regra de prioridade absoluta, ou seja, a participação de sócios na companhia reorganizada. ${ }^{419} \mathrm{O}$ sistema provou-se custoso e improdutivo. Em 1978, o legislador norte-americano flexibilizou a regra e permitiu que as partes negociassem sem respeito à ordem de prioridade absoluta, mas, caso houvesse oposição por um credor, não seria possível a imposição do plano pela via do cram down, a menos que houvesse respeito à regra. ${ }^{420}$ Apesar disso, na prática, constatou-se que desvios em relação à prioridade absoluta ocorriam ordinariamente. ${ }^{421}$ Discute-se, portanto, o que explica essa natural tendência ao reconhecimento da necessidade de que os sócios participem do capital da companhia reestruturada.

417 Robert ScOtт, "The Truth about Secured Financing”, in Cornell L. Rev., vol. 82, 1997, pp. 14361465, p. 1437 (apontando que o início dos debates teria ocorrido em 1979).

418 DOUglas G. BAIRD, Robert K. RASMUSSEN, "Control Rights, Priority Rights, and the Conceptual Foundations of Corporate Reorganizations”, in Va. L. Rev., vol. 87, 2001, pp. 921-959, p. 931.

$419 \quad$ Id., p. 935.

420 DAVID A. SKeEl JR., Debt's Dominion - A History of Bankruptcy Law in America, cit., p. 176.

421 Allan C. Eberhart, William T. Moore, Rodney L. Roenfeldt, "Security Pricing and Deviations from the Absolute Priority Rule in Bankruptcy", cit., pp. 1457-1469; JULIAN R. FRANKS, WALTER N. TOROUS, “An Empirical Investigation of U.S. Firms in Reorganization”, cit., pp. 747-769 
Intrigados por essa circunstância, diversos estudos econômicos passaram a questionar se haveria motivos para a regra ser contrária àquilo que ocorre na realidade, tendo em vista que, na prática, os sócios participam do capital da companhia reorganizada ainda que nem todos os credores tenham sido pagos. Uma linha de pesquisa econômica respondeu de forma negativa. Analisada sob a perspectiva ex ante, a possibilidade de manter a participação no capital social pelo devedor ou sócios do devedor, contrariamente à regra de absolute priority, comprovou-se eficiente. Em estudos recentes, ${ }^{422}$ concluiu-se que a manutenção dos sócios facilita a transmissão de informações para os credores e incentiva a deflagração rápida de medidas de recapitalização, ou de reorganização, ${ }^{423}$ além de evitar que os sócios administradores assumam riscos desproporcionais, "apostando com capital alheio". ${ }^{424}$ Sem a possibilidade de participação dos sócios, perdem-se, ainda, seus conhecimentos e habilidades específicas, necessárias - em companhias fechadas, por vezes imprescindíveis - para a continuidade da atividade empresarial. ${ }^{425}$

Analisada sob a perspectiva ex post, a regra tampouco teria fundamento, pelo fato de que, se só há recursos para a satisfação dos credores garantidos, por exemplo, os créditos detidos pelos credores quirografários não teriam nenhum valor. Nessa hipótese, a determinação acerca da composição societária da sociedade devedora reorganizada deveria ser atribuída somente aos credores com garantia. Caso esses considerem que a concessão de participação societária aos antigos acionistas é útil, essa será questão privada entre os credores garantidos e os antigos acionistas. Os credores que nada teriam a receber não deveriam poder interferir. ${ }^{426}$ Por conta disso, não deveria ser proibida a concessão de participação aos sócios, mesmo antes da plena satisfação dos credores.

\footnotetext{
422 cf. LUCIAN A. BEBCHUK, "Ex Ante Costs of Violating Absolute Priority in Bankruptcy", in J. Fin., vol. 57, 2002, pp. 445-460, p. 446.

423 LuCIAN A. BeBCHUK, "Ex Ante Costs of Violating Absolute Priority in Bankruptcy”, cit., p. 446.

424 HORST EIDENMÜLLER, "Obstruktionsverbot, Vorrangsregel und Absonderungsrechte", in FRANK RICHTER, ANDREAS SCHÜLER, BERNHARD SCHWETZLER (org.), Kapitalgeberansprüche, Marktwertorientierung und Unternehmenswert - Festschrift für Prof. Dr.Dr. h.c. Jochen Drukarczyc zum 65. Geburtstag, München, Franz Vahlen, 2003, pp. 188-203, p. 191.

425 DOUglas G. BAIRD, RoBert K. RASMUSSEN, "Control Rights, Priority Rights, and the Conceptual Foundations of Corporate Reorganizations", cit., p. 942-945.

426 Douglas G. BAIRD, ThOMAS H. JACKSON, "Bargaining After the Fall and the Contours of the Absolute Priority Rule", in U. Chi. L. Rev., vol. 55, 1988, pp. 738-789, p. 761.
} 


\subsection{CRÍTICA À NECESSIDADE DE AVALIAÇÃo JUDICIAL}

Como a aprovação por meio do cram down exige que o magistrado acerca avalie o valor da companhia, foram formuladas alternativas para que a avaliação fosse realizada utilizando a percepção do mercado acerca do valor da empresa.

Há duas principais propostas nesse sentido. A primeira, de Mark Roe, consiste em separar a definição sobre a continuidade da empresa da definição acerca de sua nova composição societária. Ao votarem sobre o plano, os credores não apenas analisam se a empresa é viável, mas também se o plano lhes é conveniente. ${ }^{427}$ Isso pode levar a decisões discordantes: o credor pode considerar a empresa viável, mas o plano pode lhe parecer inconveniente, ou vice-versa, o que faz com que credores com prioridade não tenham interesse na manutenção da empresa. ${ }^{428}$ Além disso, o sistema seria ineficiente por se basear na avaliação judicial do valor da empresa devedora como pressuposto para o cram down. Como juízes não têm expertise em avaliações, tendem a confiar demais nas informações prestadas pelo devedor, e a avaliar a empresa em termos favoráveis ao devedor. ${ }^{429}$ Roe pretende diferenciar essas decisões. Os credores analisariam somente a viabilidade da empresa, ao decidir se aceitam ou não a adoção das medidas propostas no plano. ${ }^{430}$ Em momento seguinte, caberia avaliar o valor da companhia, mas, para tanto, o melhor mecanismo seria o de oferecer publicamente $10 \%$ de suas ações. O valor obtido indicaria o valor total da companhia (dez vezes o valor obtido), e, então, os credores receberiam participação correspondente a seus créditos. ${ }^{431}$

Entretanto, tal modelo envolve diversos problemas práticos. Por conta de assimetrias informacionais em alta medida existentes no cenário da empresa em crise, potenciais compradores serão afastados ou ajustarão negativamente suas propostas para embutir no valor de sua prestação o risco do investimento. ${ }^{432}$ Há segundo óbice concreto: a alienação de $10 \%$ do capital não oferece ao adquirente a possibilidade de controlar a empresa; pelo contrário, segundo a proposta, o comprador participaria na condição de acionista

427 MARK J. ROE, "Bankruptcy and Debt: a New Model for Corporate Reorganization", in Colum. L. Rev., vol. 83, 1983, pp. 527-602, pp. 534-536.

$428 \quad$ Id., pp. $542-543$.

$429 \quad$ Id., pp. 547-548.

$430 \quad I d .$, pp. 540.

$431 \quad$ Id., pp. 559.

432 HORST EIDENMÜLLER, Unternehmenssanierung zwischen Markt und Gesetz, cit., p. 36 e p. 98. 
possivelmente minoritário, tendo os demais credores como sócios. ${ }^{433}$ Como terceiro impedimento, a "importação" desse modelo para países com direito societário e com configuração do mercado de capitais distintos do norte-americano mostra-se difícil. ${ }^{434}$ No Brasil, não seria possível a imposição de alteração societária contra a vontade dos acionistas; ${ }^{435}$ ademais, a maior parte das sociedades em recuperação judicial não é organizada sob a forma de companhia aberta e não pode emitir valores mobiliários (LSA, art. $4^{\circ}$ ). A regra, por fim, impõe a todos os credores, necessariamente, a transformação de seus créditos em participação societária, o que pode ser de pouco interesse para certos credores, caso a companhia reestruturada não tenha ações com liquidez.

Uma segunda proposta busca evitar o problema da avaliação pelo mercado, ao internalizar o processo de avaliação entre os credores. Lucian Bebchuk propôs um modelo de reorganização que prescinde da avaliação judicial do valor da empresa. Sua proposta é a de que, ao ingressar em processo de reorganização, as ações da companhia devedora deveriam ser canceladas, e novas ações e opções deveriam ser alocadas aos credores. Como exemplo, o autor propõe que uma companhia com capital dividido em 100 ações deva 100 dólares aos credores garantidos e 100 dólares aos credores quirografários. ${ }^{436}$ Nessa hipótese, as dívidas seriam canceladas, e novas ações seriam emitidas para os credores com garantia. Concomitantemente, os credores quirografários teriam uma opção de compra em face da companhia no valor de 1 dólar. Caso exerçam essa opção, a ação do credor com garantia é amortizada pela companhia, e uma nova ação é emitida para o credor quirografário. No momento subsequente, os antigos acionistas recebem também uma

\footnotetext{
$433 \quad$ Id., p. 99.

$434 \quad$ Christian HeRWEg, Das Obstruktionsverbot bei der Unternehmenssanierung, cit., p. 137.

435 NELSON M. MACHADO defende posicionamento contrário, considerando que o magistrado pode impor medidas de ordem societária contra a vontade dos sócios ("A Assembleia Geral de Credores e seus Conflitos com a Assembléia Geral de Acionistas”, in Rodrigo R. M. DE CASTRO, LEANDro S. DE ARAGÃO (coord.), Direito Societário e a Nova Lei de Falências e Recuperação de Empresas, São Paulo, Quartier Latin, 2006, pp. 147-162, p. 160). Com a devida vênia, discorda-se do autor. Não há fundamento dogmático para a supressão da manifestação de vontade dos acionistas, pois o artigo 50, II da LRF afirma, expressamente, que devem ser "respeitados os direitos dos sócios, nos termos da legislação vigente". A proposta também parece pressupor que a negativa dos acionistas terá sempre motivação emulativa, o que nem sempre é verdadeiro. A assembleia geral de acionistas pode ter conferido aos administradores autorização para propor plano de recuperação judicial, mas não ter analisado previamente o conteúdo concreto do plano (LSA, art. 122, IX), ou o plano proposto pode ter sido modificado pelos credores (LRF, art. 35, I, "a"). Nessa hipótese, pode haver motivo razoável para que os acionistas não concordem com a alteração societária proposta, que pode consistir, por exemplo, na alienação de suas próprias ações (LRF, art. 50, III), e que pode situá-los - embora não seja provável - em situação inferior à que estariam na falência. Percebe-se, com isso, que a solução de impedimento de voto se mostraria extremamente gravosa.

436 LUCIAN A. BEBCHUK, “A New Approach to Corporate Reorganizations”, in Harv. L. Rev., vol. 101, 1988, pp. $775-804$, p. 782.
} 
opção, cujo preço de exercício é de 2 dólares. Com o exercício da opção pelos acionistas, o preço de exercício deve ser utilizado para a amortização das ações dos credores quirografários. Assim, imagine-se que os credores quirografários consideram que a empresa valha 150 dólares, e que cada nova ação valha 1,5 dólares. Nessa hipótese, certamente desembolsarão o valor de 1 dólar, pois receberão uma ação que estimam valer 1,5 dólares. ${ }^{437}$ Além disso, segundo o modelo, cada classe de participantes teria um prazo de 5 dias para tomar sua decisão, e, na sequência, as opções seriam livremente negociadas no mercado. ${ }^{438}$

A proposta tem a vantagem de não exigir uma avaliação da empresa e se baseia em um raciocínio matemático coerente. Como cada participante deve receber uma parcela da empresa, não é necessário saber qual o valor da empresa, mas somente distribuir o valor existente (seja lá qual for) de acordo com a hierarquia falimentar. Entretanto, o sistema pressupõe que os credores quirografários e os acionistas tenham recursos financeiros disponíveis para exercer suas respectivas opções de compra ou que consigam negociá-las no mercado. ${ }^{439}$ Isso nem sempre ocorre, sobretudo com acionistas de uma empresa em crise, pois, se eles tivessem capital disponível, provavelmente teriam investido na companhia aumentando seu capital. Percebe-se, com isso, que a proposta afastaria de forma praticamente completa os antigos acionistas no capital da companhia reestruturada. Sob o véu da suposta neutralidade econômica, oculta-se inconfundível direcionamento político.

Analisando os dois modelos alternativos propostos para viabilizar a superação do veto do credor prescindindo da avaliação do valor da empresa, pode-se afirmar que nenhum deles é satisfatório. Ademais, por promoverem o afastamento dos sócios da sociedade devedora do capital da companhia reorganizada, podem ser vistos como formas alternativas de liquidação, mas não de reorganização empresarial.

\footnotetext{
$437 \quad$ Id., pp. 786-788.

$438 \quad$ Id., p. 789.

439 ChrISTIAN HerWEg, Das Obstruktionsverbot bei der Unternehmenssanierung, cit., p. 166.
} 


\subsubsection{SÍNTESE}

O estudo dos mecanismos de superação do veto de credores encontrados nos ordenamentos norte-americano e alemão demonstra que sua operacionalidade não é simples. Envolvem a avaliação da empresa e pressupõem, no mais das vezes, a impossibilidade de os sócios permanecerem titulares de participações societárias - na contramão do que ocorre na recuperação judicial no Brasil. Com a correta compreensão desses mecanismos, pode-se considerar que nenhum deles oferece uma alternativa que pudesse ser incorporada no procedimento de recuperação judicial por via interpretativa. Ademais, alteração legislativa que buscasse implementar um mecanismo semelhante ao cram down no Brasil provavelmente alteraria drasticamente o feitio das recuperações judiciais, com possível afastamento em relação à inspiração preservacionista inscrita no artigo 47 da LRF.

\subsubsection{Abuso do direito de voto como FORMA DE CONTROLE do COMPORTAMENTO OBSTRUTIVO}

No direito brasileiro, não há um instrumento institucionalizado para a superação da rejeição ao plano imposta por um credor, por menos justificada que seja. As maiorias exigidas por lei para a aprovação do plano aprovação previstos na lei são rígidas, e não autorizam análise do mérito do comportamento do credor pelo magistrado. $\mathrm{O}$ abuso do direito de voto, porém, pode se configurar por meio da adoção de comportamento obstrutivo.

\subsubsection{POSSIBILIDADE DE OBSTRUÇão}

A aprovação de plano de recuperação judicial pressupõe a obtenção de maioria entre os credores integrantes das classes dos credores garantidos e quirografários, contados por cabeça e por valor de créditos (LRF, art. $45, \S 1^{\circ}$ ), e da maioria simples dos credores titulares de créditos derivados da legislação do trabalho ou decorrentes de acidentes de trabalho presentes à assembleia (LRF, art. $\left.45, \S 2^{\circ}\right)$.

Caso esse quorum não tenha sido alcançado, a LRF prevê uma forma alternativa de aprovação do plano que supere o voto contrário proferido por determinados credores e que 
comumente vem sendo designada como cram down. ${ }^{440}$ É possível, portanto, a aprovação do plano se forem obtidos, cumulativamente: voto favorável de mais da metade do valor de todos os créditos, independentemente de classes (LRF, art. 58, §1 ${ }^{\circ}, \mathrm{I}$ ); aprovação pela maioria das classes votantes, ou de ao menos uma delas, caso haja somente duas (LRF, art. $\left.58, \S 1^{\circ}, \mathrm{II}\right)$; aprovação por crédito e por cabeça por mais de $1 / 3$ dos credores integrantes da classe que houver rejeitado o plano (LRF, art. $\left.58, \S 1^{\circ}, \mathrm{II}\right)$. Ademais, é pressuposto que não tenha ocorrido tratamento diferenciado entre os credores da classe que houver rejeitado o plano (LRF, art. 58, §2 $2^{\circ}$.

Se um credor for titular de mais de 2/3 dos créditos de uma classe, terá a possibilidade de impedir a aprovação de qualquer plano de recuperação judicial, ainda que não tenha motivos legítimos para tanto. Não há na lei um mecanismo análogo ao mecanismo de cram down norte-americano que permita ao magistrado anular o voto proferido sem motivo legítimo.

\subsubsection{JURISPRUDÊNCIA}

Diante da impossibilidade de superar o comportamento obstrutivo do credor caso não sejam alcançadas as maiorias previstas nos artigos 45 e 58 da LRF, a jurisprudência não tardou a enfrentar situações em que se mostrava impossível a superação do voto de rejeição ao plano proferido por um credor. Os Tribunais de Justiça de São Paulo, ${ }^{441}$ de Rondônia ${ }^{442}$ e do Rio Grande do $\mathrm{Sul}^{443}$ enfrentaram situações em que a classe dos credores com garantia real (classe II) era composta por apenas um credor, que rejeitou a proposta de plano de recuperação judicial. Em todas as decisões mencionadas, decidiu-se que o veto de um credor poderia ser anulado por abuso do direito de voto, concedendo-se, com isso, a recuperação judicial. Como fundamento das decisões, encontra-se, em todas, menção (i) à

440 cf. Carolina S. J. Batista, Paulo Fernando Campana Filho, Renata Y. Miyazaki, e Sheila C. N. CerezetTI, “A Prevalência da Vontade da Assembleia Geral de Credores em Questão: o Cram Down e a Apreciação Judicial do Plano Aprovado por todas as Classes”, cit., pp. 204-215 (sublinhando, porém, as marcadas diferenças entre a versão brasileira do instituto e seus congêneres estrangeiros).

441 TJSP, AI n. 649.192-4/2-00, Câm. Esp. de Fal. e Rec. Jud., REl. Des. Romeu Ricupero, v.u., j. 18.08.2009, DJ 28.08.2009. No mesmo sentido, TJSP, AI n. 627.497-4/3-00, Câm. Esp. de Fal. e Rec. Jud., REL. DeS. Romeu Ricupero, v.u., j. 30.06.2009, DJ 08.07.2009; e TJSP, AI n. 368.631-4/1-00, Câm. Esp. de Fal. e Rec. Jud., REL. DES. ROMEU RICUPERO, v.u., j. 18.08.2009, DJ 28.08.2009.

442 TJRO, AI n. 100.010.2006.006147-0, 1ª Câm. Civ., Rel. Des. GABriEl MARQues De CARVAlHO, v. u., j. 04.09.2007.

443 TJRS, AI n. 70018219824, 6a Câm. Cív., Rel. Des. ARTUR ARNILDO Ludwig, v.u., j. 19.04.2007, DJ 21.05.2007. 
contundente aprovação pelas demais classes; (ii) à viabilidade da empresa, sem que, contudo, haja referência a laudos econômicos que a atestem; e (iii) à função social da empresa em crise, prevista no artigo 47 da LRF, como fundamento para negar validade ao voto contrário à recuperação judicial, e que determina a falência da empresa em crise.

As decisões dos tribunais de justiça estaduais mencionadas são passíveis de crítica. Em primeiro lugar, como já discorrido neste estudo (item 2.2.1, supra), a intervenção do Estado-juiz para o controle do processo de aprovação do plano não pode ocorrer com recurso direto à função social da empresa; ela reclama para sua concretização instrumentos procedimentais previsíveis.

Em segundo lugar, a menção ao fato de que credores quirografários e trabalhistas teriam sido favoráveis à recuperação judicial não é fundamento apto a fazer presumir que o comportamento do credor garantido que rejeita o plano seja abusivo. Cada credor que analisa a proposta de recuperação judicial compara aquilo que receberá na falência com aquilo que receberá na recuperação judicial. Se os credores integrantes de classes diversas receberão valores diversos na falência e na recuperação judicial, não é possível extrair da aprovação por outras classes nenhum juízo quanto ao comportamento do credor divergente. Há, nesse argumento, apenas uma redundante afirmação de que os credores que aceitaram o plano estão com ele satisfeitos.

Em terceiro lugar, as decisões afirmam que as empresas em crise eram viáveis, mas limitam-se a apontar dados genéricos referentes a perspectivas de soerguimento. Contudo, para afirmar que uma empresa é viável, o magistrado deve demonstrar as razões que o levaram a alcançar essa convicção, tornando possível o contraditório em relação a suas premissas.

\subsubsection{DOUTRINA}

Desde a edição da Lei de Recuperação e Falência, o sistema de aprovação do plano de recuperação judicial pelo sistema do artigo 58 da LRF vem sendo objeto de severas críticas 
por seu caráter "legalista [e] fechado", 444 que o reduz a um quorum alternativo de aprovação do plano, sem margem para a apreciação de eventual abuso pelo juiz. ${ }^{445}$

Em recente tese de doutorado, Álvaro Mariano defendeu, em síntese, que, não obtidas as maiorias exigidas em lei, não restaria alternativa ao magistrado. $O$ voto de um credor contra um plano de recuperação e a favor da falência nunca poderia ser considerado abusivo. Para o autor, a falência, na nova configuração que lhe foi dada pela Lei de Recuperação e Falência, permite a preservação da empresa tanto quanto a recuperação judicial. $^{446}$

Com a devida vênia, parece que seja possível a ocorrência de abuso na deliberação que rejeita um plano de recuperação judicial e, ademais, que a figura do abuso do direito de voto ofereça fundamento dogmático para controlar a legalidade do voto assim proferido. Ainda que o cram down brasileiro seja legalista e fechado, o exercício do direito de voto não pode desrespeitar os limites impostos pelo seu fim econômico ou social, pela boa-fé, ou pelos bons costumes (CC, art. 187).

Sem adotar esse fundamento, mas caminhando nesse sentido, Eduardo Munhoz propõe como alternativa teórica para a concretização do disposto no art. 47 da LRF o reconhecimento da possibilidade de o juiz aprovar um plano de recuperação judicial rejeitado pela assembleia geral de credores, desde que fosse assegurado (i) que nenhum credor recebesse menos do que receberia na falência (best-interest-of-creditor), ou (ii) que os credores que rejeitarem o plano recebessem tratamento semelhante e proporcional ao dispensado à maioria dos credores com crédito da mesma natureza (unfair discrimination). ${ }^{447}$

\footnotetext{
444 Alberto C. Moreira, "Poderes da Assembléia de Credores, do Juiz e Atividade do Ministério Público", cit., p. 258.

445 Eduardo S. Munhoz, in Francisco S. DE SouZa JR., Antônio S. A. DE M. Pitombo (coord.), Comentários à Lei de Recuperação de Empresas e Falência, cit., p. 289.

446 ÁlVARO A. C. MARIANO, Abuso de Voto na Recuperação Judicial, Tese de Doutorado apresentada à Faculdade de Direito da Universidade de São Paulo, São Paulo, 2012, p. 297: "o voto pela quebra do devedor, por si mesmo, não constitui violação dos limites econômicos e sociais do direito e, portanto, isoladamente, não pode ser considerado um abuso do direito."

447 EDUARDO S. MUNHOZ, "Anotações sobre os limites do poder jurisdicional na apreciação do plano de recuperação judicial”, in $R D B$, ano 10, n. 36, 2007, pp. 184-199, p. 198.
} 


\subsubsection{POSICIONAMENTO: POSSIBILIDAdE DE ABUSO DO DIREITO DE VOTO POR COMPORTAMENTO OBSTRUTIVO}

O dever de lealdade existente entre os credores não exige que o credor ponha seu crédito a serviço da comunhão. Exige-se, contudo, que o credor não prejudique a comunhão nem prejudique outros credores sem interesse legítimo.

\subsection{POSSIBILIDAdE DE QUE FALÊNCIA SEJA PREJUDICIAL AOS CREDORES}

É verdade que, nem sempre, a falência da empresa levará à sua paralização, bem como é verdade que a falência permite e estimula a adoção de formas liquidatórias que priorizem a continuidade das atividades empresariais (LRF, art. 75). ${ }^{448}$ É certo, ademais, que, em determinadas circunstâncias, a falência pode promover melhor satisfação dos credores do que um plano de recuperação judicial. Entretanto, isso não exclui a possibilidade inversa: um plano de recuperação judicial pode, em certas hipóteses, permitir a melhor satisfação dos credores. Diferentes fatores podem contribuir para esse resultado.

Em primeiro lugar, o devedor, ou os sócios do devedor, podem ser detentores de conhecimentos específicos imprescindíveis para a gestão da empresa, e esses conhecimentos podem ser perdidos na falência. ${ }^{449} \mathrm{Em}$ segundo lugar, enquanto os ativos não forem liquidados, a empresa deverá ser administrada pelo gestor judicial. Diferentemente de um empresário, o gestor judicial não recebe maior remuneração se obtiver maior lucro para a empresa (LRF, art. 24); todavia, responde pelos prejuízos que impuser à massa e não receberá remuneração se tiver suas contas desaprovadas (LRF, art. $24, \S 4^{\circ}$ ). É possível, portanto, que adote comportamento extremamente conservador, com aversão a riscos que seriam adequados para um empresário. Em terceiro lugar, danos à imagem da empresa podem prejudicar sua reputação e capacidade de negociação junto a outros agentes. ${ }^{450}$ Embora não se tenha notícia de estudo empírico analisando os efeitos da falência sobre a capacidade de negociação da empresa em crise, em comparação com o cenário de recuperação judicial, esse efeito adverso pode ocorrer. Em quarto lugar, o

\footnotetext{
448 Sobre o assunto, cf. AdRIANA V. P. GARDINO, A Falência e a Preservação da Empresa: Compatibilidade?, Tese de Doutorado apresentada à Faculdade de Direito da Universidade de São Paulo, São Paulo, 2012.

449 LORENZO STANGHELLINI, Le crisi di impresa fra diritto ed economia, cit., p. 180.

450 HORST EIDENMÜLLER, Unternehmenssanierung zwischen Markt und Gesetz, cit., pp. 75-76.
} 
mercado, em geral, não avalia adequadamente empresas em crise. Devido à alta assimetria informacional existente entre um potencial comprador e a empresa falida ${ }^{451}$ e à necessidade de promover uma alienação rápida para diminuir perdas, o valor obtido em uma venda da empresa pode ser inferior ao que seria obtido em sua recuperação - ainda que a lei exima o adquirente de responsabilidade por passivos trabalhistas e fiscais. Em quinto lugar, custos diretos da falência, ligados, por exemplo, à remuneração do gestor judicial, podem superar os custos envolvidos na recuperação judicial.

\subsection{CRITÉRIOS PARA VERIFICAÇÃO DO VOTO ABUSIVO}

É possível, portanto, que a rejeição a um plano de recuperação judicial prejudique os demais credores. Se essa rejeição não for movida por um interesse legítimo do credor, há abuso do direito de voto. Entretanto, é necessário determinar como seria possível aferir se o plano de recuperação judicial é favorável aos credores e se não há prejuízos ao credor votante, de forma que se possa denominar abusiva sua rejeição ao plano proposto.

A lei confia aos credores a decisão acerca da viabilidade do plano. Uma decisão judicial que busque avaliar se a rejeição a um plano é abusiva terá de lidar, no mais das vezes, com planos que não obtiveram as maiorias necessárias para a sua aprovação. Se esse critério for adotado também para a verificação de eventual abuso, ou a resposta será circular - o plano não beneficia os credores porque não alcançou as maiorias necessárias - ou criará novas maiorias não previstas na lei - é o caso dos acórdãos analisados, que afirmam que o plano beneficia os credores porque foi aprovado por credores trabalhistas e quirografários e somente não foi aprovado por conta do interesse egoístico do credor com garantia real. Nenhuma das alternativas se mostra adequada.

Caso se constate que o voto proferido pelo credor foi abusivo, a consequência será sua invalidação (item 5.1, infra). A aprovação do plano poderá, então, ocorrer sem o seu consentimento e sem que tenham sido alcançadas as maiorias exigidas em lei. É necessário, portanto, garantir que o plano de recuperação judicial não desrespeite interesses legítimos dos credores. Se a análise de viabilidade dos credores é possívelmente viciada,

451 HORST EIDENMÜLLER, Unternehmenssanierung zwischen Markt und Gesetz, cit., p. 36. 
será necessária a adoção de outra forma de aferição. No procedimento de recuperação judicial, sua promoção caberá ao magistrado.

Diante da impossibilidade de contar com a avaliação dos credores acerca do devedor, deve o magistrado avaliar (i) se a empresa em crise forneceu informações verossímeis; (ii) se as medidas de reerguimento propostas no plano são passíveis de serem adotadas pela empresa; e (iii) se é provável que o plano de recuperação judicial conduza a uma efetiva superação do estado de crise.

A análise deve ser fática e o magistrado, para realizá-la, poderá se valer de perícia. $^{452} \mathrm{~A}$ solução sem dúvida permite certo subjetivismo do magistrado, que terá de afirmar a probabilidade de ocorrência de eventos futuros. Há, naturalmente, espaço para certa subjetividade. Entretanto, pela leitura dos acórdãos analisados, a jurisprudência já vem fundamentando decisões invocando a viabilidade da empresa em crise. O que se propõe, então, não é alteração fundamental, mas a adoção de postura que proporcione incremento na transparência e na objetividade das decisões.

A etapa seguinte consiste em determinar se o comportamento carece de fundamento legítimo. Na deliberação sobre o plano de recuperação judicial, está em questão uma decisão econômica. Conquanto essa decisão seja tomada de forma discricionária pelo credor, sua legalidade encontra limites ausência de interesse legítimo para a rejeição ao plano.

No âmbito da recuperação judicial, o fundamento legítimo para a rejeição ao plano proposto pode ser encontrado na comparação entre a posição em que estaria o credor na hipótese de falência e de recuperação judicial. Caso se compare a satisfação provável do credor sob a falência com o pagamento proposto no plano de recuperação judicial e conclua-se que o plano propõe pagamento superior ao que seria obtido na falência, pode haver abuso do direito de voto. A superioridade, contudo, deve ser manifesta. $\mathrm{O}$ requisito consta do artigo $187 \mathrm{CC}$ para a configuração do abuso do direito e mostra-se especialmente adequado no contexto do abuso negativo do direito de voto pelo credor. Em vista da

452 Em linha com a decisão que admitiu que o magistrado pode determinar a realização de perícia para aferir o atendimento aos requisitos previstos no art. 53 da LRF (TJSP, AI n. 0194436-42.2012.8.26.0000, $1^{\mathrm{a}}$ Câm. Res. de Dir. Emp., REL. DES. TEIXEIRA LEITE, j. 02.10.2012, DJ 06.10.2012). 
grande subjetividade envolvida em avaliações econômicas, o magistrado deve-se limitar a conhecer casos de flagrante falta de interesse legítimo.

Nessa avaliação, não somente o valor oferecido, mas também o prazo para o pagamento devem ser levados em consideração. Um valor prometido no futuro vale menos do que recursos presentes, pois a perda de disponibilidade financeira pode ser associada a um custo. Para comparar o valor oferecido sob o plano com o que o credor receberia na falência, é necessário, portanto, converter os valores futuros em valor presente, com aplicação de adequada taxa de desconto. A jurisprudência norte-americana a respeito do assunto oferece exemplos de como isso pode ser realizado, muito embora as diversas discussões jurisprudenciais testemunhem a complexidade dessa definição.

\subsection{COMPARAÇÃO DE POSICIONAMENTO COM SOLUÇÃO NORTE-AMERICANA}

Apresentado o posicionamento que se considera adequado para a avaliação do abuso negativo do direito de voto, cabe cotejá-lo com a solução adotada no direito norteamericano. $^{453}$

Em primeiro lugar, a análise do veto obstrutivo pressupõe a análise da viabilidade do plano pelo magistrado. A medida é protetiva para os interesses dos próprios credores, inclusive daquele que, supostamente, abusou do seu direito de voto. Essa etapa da avaliação proposta neste trabalho corresponde, em essência, ao teste de feasibility norte-americano (BC, $\S 1129(\mathrm{a}))$.

Em seguida, é necessário averiguar se o credor receberia, sob o plano, manifestamente mais do que receberia na falência. $O$ teste se assemelha, no essencial, ao teste americano de best-interest (BC, §1129(a)(7)). Tal qual no teste norte-americano, mostra-se imprescindível a realização de juízo econômico pelo magistrado, necessidade para a qual, até hoje, a doutrina estadunidense não encontrou alternativas (cf. item 4.2.1.3.3, supra). Não poderia ser de outra forma. Em matéria econômica, somente se pode censurar a falta de legitimidade de um comportamento após analisar razoabilidade da decisão em relação a seus possíveis efeitos (recuperação ou falência).

453 Com isso, há comparação também com a solução alemã, largamente inspirada na norte-americana. 
O teste de unfair discrimination (BC, §1129(b)(1)) norte-americano, por sua vez, deve ser realizado sempre pelo magistrado brasileiro (cf. item 2.3.1.2, supra), pois o plano que confira tratamento discriminatório a determinado credor é ilegal. Assim, a observância à proibição de discriminação injustificada deve ser garantida antes da própria deliberação.

Com essa forma de procedimento, porém, o abuso negativo do direito de voto é aferido sem que seja observado parâmetro semelhante à absolute priority rule norte-americana (BC, §1129(b)). A regra determina, como se viu, que não pode haver aprovação do plano se credores de classe inferior, ou o devedor, ou seus sócios, receberem algum valor sob o plano antes da plena satisfação dos créditos com maior preferência.

Esse parâmetro, efetivamente, não deve ser considerado para a verificação do abuso negativo do direito de voto. Em primeiro lugar, já se ressaltou que mesmo no sistema norte-americano a regra é objeto de críticas (item 4.2.1.3.1 e item 4.2.1.3.2, supra). Em segundo lugar, a observância desse parâmetro para considerar o veto do credor como abusivo impossibilitaria a formação de consensos, pois exigiria a plena satisfação dos credores com ordem de prioridade falimentar superior. Porém, se fosse possível prever a plena satisfação desses credores sob o plano, decerto o devedor teria oferecido tal condição de pagamento no plano, pois assim o credor rejeitante sequer participaria da deliberação (LRF, art. $\left.45, \S 3^{\circ}\right)$. Em terceiro lugar, considerando que só há voto abusivo se o credor recebe sob o plano manifestamente mais do que receberia na falência, fica garantido o respeito à hierarquia falimentar, ainda que outros credores sejam satisfeitos. Em quarto lugar, o objetivo do procedimento de recuperação, cumpre enfatizar, não é somente o de preservar a empresa (pois, para isso, bastaria a falência - LRF, art. 75), mas também o de possibilitar a continuidade da empresa com manutenção do empresário. Ao exigir que o devedor, ou seus sócios, não participassem do capital social da sociedade recuperada, estar-se-ia impondo exigência que degradaria a recuperação judicial, transformando-a em processo de liquidação. 


\subsection{CASUÍSTICA}

O abuso do direito de voto pode ocorrer em todas as classes de créditos. Tendo em vista que em cada uma das classes de créditos se encontram credores situados em diferentes níveis na ordem de prioridade falimentar, a análise do abuso negativo de direito de voto deve ser igualmente diferenciada.

A classe I é composta pelos titulares de créditos derivados de acidentes do trabalho e de relações trabalhistas. Na falência, os créditos derivados de acidentes do trabalho e os créditos trabalhistas no valor de até 150 salários mínimos por trabalhador serão os primeiros a serem pagos (LRF, art. 83, I). A rejeição a um plano que proponha o pagamento de valor inferior a esses credores dificilmente poderá ser considerada abusiva, pois, na falência, é quase certo que esses credores serão integralmente pagos. Todavia, para um credor trabalhista que seja titular de créditos em valores superiores a 150 salários mínimos, é possível que ocorra abuso do direito de voto. Na falência, a parte que sobejar o valor de 150 salários é enquadrada como crédito de natureza quirografária (LRF, art. 83, VI, “c”). Na recuperação judicial, por sua vez, o credor vota com a totalidade de seu crédito na classe I (LRF, art. $\left.41, \S 1^{\circ}\right)$. É possível, portanto, que rejeite um plano que lhe ofereça tratamento superior ao que receberia na falência. Nessa hipótese, se o tratamento proposto no plano for manifestamente superior, haverá abuso do direito de voto.

Os credores com garantia real, integrantes da classe II, obterão na falência o valor relativo à excussão de sua garantia com prioridade sobre os demais credores; eventual valor de seu crédito não coberto pela garantia será classificado como crédito quirografário (LRF, art. 83, VI, "b"). Para a satisfação do credor com garantia deverá ser excutido o bem sobre o qual recai a garantia. Para tanto, serão incorridos custos com a realização de leilão ou praça, que diminuirão o valor recebido prioritariamente pelo credor. É possível, portanto, que haja abuso do direito de voto, se o plano previr pagamento ao credor superior ao pagamento que o credor provavelmente obteria na falência. Isso pode ocorrer se o plano previr, por exemplo, o pagamento diferido do crédito, oferecendo remuneração adequada, de forma que, convertidos em valor presente, os valores oferecidos ao credor sob o plano sejam manifestamente superiores ao que ele obteria na falência. Também nessa hipótese pode ocorrer abuso negativo do direito de voto. 
No caso dos credores integrantes da classe III, a mesma análise deve ser realizada, mas a possibilidade de abuso negativo do direito de voto é remota. Os credores integrantes dessa classe receberão pagamento apenas após o fisco (LRF, art. 83, III c/c V, VI, VII e VIII). Ainda assim, a análise deve ser casuísta. 


\section{SANÇÕES AO ABUSO DO DIREITO DE VOTO}

Caso seja constatado o abuso do direito de voto, duas consequências podem ocorrer: a invalidade do voto exercido e a responsabilização civil do credor que tenha abusado do seu direito de voto.

\subsection{INVALIDADE DO VOTO}

Se não são respeitados os limites impostos pela boa-fé, pela função social e pelos usos e costumes, o exercício do direito revela-se abusivo, e o ordenamento jurídico recusa-lhe efeitos de forma peremptória. O ato abusivo é considerado ilícito pela lei (CC, art. 187) e, portanto, o voto proferido abusivamente deve ser considerado nulo.

A Lei de Recuperação e Falência não regula a possibilidade de anular a deliberação tomada pelos credores, tampouco os requisitos para essa anulação, embora admita que a deliberação assemblear possa ser invalidada (LRF, art. 39). Entretanto, a doutrina esclarece que a anulação da deliberação aprovada com base em voto nulo não é, em si, nula; a deliberação é anulável. ${ }^{454}$

Com a anulação da deliberação decorrente de voto nulo, a deliberação é considerada inválida e deixa de gerar efeitos. Se, na deliberação, foi aprovado ou rejeitado um plano de recuperação judicial, a deliberação é tida por não ocorrida e as partes são restituídas ao status quo ante. O resultado, contudo, é insatisfatório, pois desconsidera que, sem o voto nulo, há, ainda, a manifestação de voto dos demais credores, que normalmente é suficiente para a formação de vontade da comunhão.

Deve-se questionar, assim, a possibilidade de que, além da anulação da assembleia, seja possível a propositura daquilo que os alemães denominam ação declaratória positiva assemblear (positive Beschlussfeststellungsklage), ação que tem, no direito alemão eficácia constitutiva (é Gestaltungsklage), a despeito de sua denominação. ${ }^{455}$ Por meio dessa ação,

454 Erasmo V. A. E N. FrançA, in Francisco S. DE Souza Junior, Antônio SÉrgio A. DE M. PITOMBo (coord.), Comentários à Lei de Recuperação de Empresas e Falência, cit., p. 193-194.

455 THOMAS RAISER, RÜDIGER VEIL, Recht der Kapitalgesellschaften, $5^{\mathrm{a}}$ ed. atual., München, Franz Vahlen, 2010, § 16, Rn. 167, p. 243. 
não somente se anula a deliberação, mas é declarada (formada) a vontade efetivamente externalizada pela assembleia após a exclusão do voto invalidado. Segundo Carsten Oelrichs, o acertamento da deliberação assemblear pode ser pleiteado não somente no âmbito societário, mas também concursal. ${ }^{456}$

A doutrina vem acentuando que também no direito societário brasileiro poderia ter cabimento a declaração positiva do conteúdo assemblear. ${ }^{457}$ No direito concursal, solução semelhante seria coerente e especialmente adequada. A realização de nova deliberação pode levar tempo, o que contrasta com o objetivo de celeridade de procedimentos recuperacionais. Assim, se o voto proferido pelos demais credores é suficiente para a formação de vontade da comunhão, parece adequado que o magistrado, além de anular a deliberação decorrente do voto nulo, proceda ao acertamento da declaração assemblear.

Nesse ponto, pode-se questionar se o magistrado, para o acertamento da deliberação, deve considerar ou não o credor que abusou do direito de voto para o cálculo das maiorias exigidas para aprovação do plano (LRF, art. 58 c/c art. 45).

A resposta mais adequada parece ser negativa. A jurisprudência do TJSP firmou posicionamento quanto ao tratamento a ser concedido ao credor que comparece ao conclave e, podendo votar, se abstém. Segundo a jurisprudência, o credor não deve ser considerado para o cômputo dos quoruns de aprovação. ${ }^{458}$ É possível, por extensão, defender que o credor que comparece e vota abusivamente possa ser equiparado ao credor que se absteve. Com isso, deve ser excluído do cômputo. Este é também o posicionamento que foi aprovado no enunciado de n. 45 da I Jornada de Direito Comercial promovida pelo Conselho da Justiça Federal: "O magistrado pode desconsiderar o voto de credores ou a manifestação de vontade do devedor, em razão de abuso de direito."

\footnotetext{
456 CARSTEN P. OELRICHS, Gläubigermitwirkung und Stimmverbote im neuen Insolvenzrecht, cit., pp. 58-59.

457 ERASmo V. A. E N. FrançA, Invalidade das Deliberações de Assembléias das S.A., São Paulo, Malheiros, 1999, pp. 94-96, n. 62 (enfatizando possíveis problemas processuais relacionados ao acertamento da declaração assemblear); e MARCELO V. VON ADAMEK, Abuso de Minoria em Direito Societário (Abuso das Posições Subjetivas Minoritárias), cit., pp. 304-306 (considerando que pode ser admitido o acertamento da deliberação assemblear).

${ }^{458}$ Nesse sentido, TJSP, AI n. 450.859-4/1-00, Câm. Esp. Fal. Rec. Jud. Dir. Priv., Rel. Des. PereirA CALÇAS, v.u., j. 17.01.2007, DJ 19.01.2007; TJSP, AI n. 0372448-49.2010.8.26.0000, Câm. Res. Fal. Rec., Rel. Des. Pereira Calças, v.u., j. 01.02.2011, DJ 09.02.2011.
} 
Assim, uma vez anulada a deliberação por abuso do direito de voto, deve-se proceder a nova análise dos votos proferidos na deliberação, desconsiderando o voto abusivo.

\subsection{RESPONSABILIDADE POR DANOS}

Caso o voto exercido abusivamente cause danos, o credor fica obrigado a repará-los. Tratase de aplicação da regra geral prevista no artigo 927 do Código Civil ao âmbito recuperacional. $\mathrm{O}$ credor que vota abusivamente e infligir danos a outrem fica responsável perante quem os sofrer.

Entretanto, como já se mencionou (item 2.1.3.4, supra), a regra geral é de responsabilidade subjetiva e não há fundamentos para impor responsabilidade objetiva ao credor que vota abusivamente. 


\section{CONCLUSÃo}

No curso deste trabalho foram analisadas as condições para a ocorrência do abuso do direito de voto na assembleia geral de credores. Cabe, assim, recapitular as principais conclusões obtidas no trabalho e tecer considerações finais.

a.

PRINCIPAIS CONCLUSÕES

Sem prejuízo de tudo o que foi exposto ao longo da dissertação, foram obtidas as seguintes conclusões:

Capítulo 1: Coletividade de credores: natureza jurídica, princípio majoritário e dever de lealdade

Com o início do procedimento concursal, os credores são reunidos em uma coletividade obrigatória que não tem natureza jurídica de pessoa jurídica, nem de litisconsórcio, nem de comunhão. Formam comunhão de interesses, instituto dogmático marcado pela circunstância de que, a despeito da ausência de copropriedade, os integrantes têm o poder de influir na esfera jurídica dos demais.

A circunstância de que um credor possa impor sua vontade aos demais, ou de que conflua para a formação da vontade majoritária, outorga-lhe um poder que não pode vir desacompanhado da respectiva responsabilidade. Como decorrência da situação de comunhão, vige, entre os credores, um dever recíproco de lealdade.

\section{Capítulo 2: Abuso do direito de voto pelo credor: fundamentos dogmáticos}

O abuso do direito tem origem na jurisprudência francesa, em que foi desenvolvido como figura dogmática apta a justificar a imposição de responsabilidade civil no caso de exercício ilegítimo de um direito. No direito alemão e, depois, no direito italiano, o instituto assumiu outra conformação, passando a restringir o exercício inadmissível de posições jurídicas com esteio na boa-fé. No Brasil, o abuso do direito sofreu a influência francesa durante a vigência do Código Civil de 1916. Com a nova codificação, o artigo 187 
CC, resultado mediato da cultura jurídica alemã, alterou a configuração do instituto. $\mathrm{O}$ abuso do direito não é, atualmente, somente fundamento para a responsabilidade civil: é limite objetivo ao exercício de posições jurídicas, aplicável ao direito de voto dos credores.

Na deliberação sobre o plano de recuperação judicial, o voto proferido pelo credor não deve ser censurado por desrespeito à função social da empresa em crise. A função social reclama, para sua concretização, soluções que garantam sua integração coerente e ponderada ao procedimento. No exercício do direito de voto, o credor deve, porém, ser pautado pela consideração à função social, aos usos e aos costumes e à boa-fé na relação bilateral com o devedor, e, principalmente, pelo respeito ao dever de lealdade entre os credores integrantes da comunhão de interesses.

Por fim, em excurso necessário, afirmou-se que, antes do controle de eventual abuso do direito de voto, deve o próprio plano de recuperação judicial ser sujeito a escrutínio, para que não contenha ilegalidades como a ausência de informações ou a concessão de tratamento discriminatório.

\section{Capítulo 3: Impedimento de voto}

O impedimento de voto é solução rígida e grave mesmo no direito societário, em que as decisões afetam imediatamente a sociedade e apenas mediatamente os sócios. $\mathrm{Na}$ deliberação acerca do plano de recuperação judicial, em que cada credor votante terá as condições de seu crédito alteradas, a técnica legislativa deve ser utilizada com ainda maior parcimônia.

No art. 43 da LRF, há hipóteses de impedimento de voto vinculadas à condição de certos credores, não a certas deliberações, em descompasso com o que ocorre no direito societário. Mesmo assim, as regras societárias não são aplicáveis por analogia.

Foram analisadas três hipóteses de impedimento de voto pouco discutidas na doutrina. No caso de todos os credores integrantes de uma classe estarem impedidos de votar, defendeuse que todos devem reassumir o voto. Caso um credor quirografário seja garantido pela alienação fiduciária de ações da sociedade devedora, defendeu-se que não há impedimento 
de voto. Caso um credor impedido de votar ceda seu crédito a terceiro, também o cessionário fica sujeito ao mesmo impedimento.

\section{Capítulo 4: Abuso do direito de voto pelo credor: aferição e casuística}

As hipóteses de abuso do direito de voto foram separadas em hipóteses de abuso positivo e de abuso negativo do direito de voto. $\mathrm{O}$ abuso positivo ocorre quando o credor se vale do seu direito de voto para a persecução de vantagem particular estranha à sua condição de credor. O abuso negativo ocorre quando adota comportamento obstrutivo, rejeitando um plano de recuperação judicial sem fundamento legítimo.

No abuso positivo do direito de voto, foi analisada casuística com as principais, ou mais prováveis, formas de ocorrência do abuso, tendo sido analisadas as seguintes hipóteses: (i) exercício do voto mediante contraprestação; (ii) abuso do direito de voto pelo estabelecimento de tratativas com o devedor; (iii) aquisição de poder de voto por meio da aquisição de créditos; (iv) abuso do direito de voto pelo credor quirografário que, não obstante sua condição, desfruta de garantia pessoal ou real outorgada por terceiro; (v) abuso do direito de voto por meio do exercício de voto em uma classe de créditos para a obtenção de tratamento vantajoso em relação a créditos de outra classe; (vi) abuso do direito de voto pelo credor concorrente que busca a falência do devedor para obter vantagens concorrenciais; e (vii) abuso do direito de voto quando o credor celebrou com o devedor negócio jurídico que estaria sujeito à revogação ou ineficácia em hipótese de falência e, para evitá-la, aceita sacrifício desproporcional ao crédito proposto em plano de recuperação judicial.

Para aferir o abuso negativo do direito de voto, o magistrado deverá analisar se o plano é viável, se as medidas nele proposta são exequíveis e se é provável que a empresa consiga superar o estado de crise com a recuperação judicial. Se esses requisitos estiverem configurados, deverá ser analisado o voto do credor para averiguar se sua rejeição ao plano teve fundamento legítimo. Esse fundamento estará ausente se o plano proporcionar ao credor manifestamente mais do que o credor receberia sob a falência. 


\section{Capítulo 5: Sanções ao abuso do direito de voto}

Foram analisadas as sanções ao abuso do direito de voto. Em vista do caráter ilícito do voto abusivo, o voto é nulo. A deliberação decorrente do voto abusivo é anulável. Nesse caso, o credor que proferiu voto abusivo deve ser excluído do cômputo do quorum de aprovação e deve ser declarado o resultado obtido exluindo-se o voto proferido abusivamente do cálculo do quorum de aprovação. Caso o exercício abusivo resulte em danos ao devedor, ao credor ou a terceiros, há responsabilidade civil, de natureza subjetiva, do credor que votou abusivamente.

\section{b. CONSIDERAÇÕES FINAIS}

Como se afirmou no prólogo deste trabalho, a Lei de Recuperação e Falência pauta-se pela adoção de soluções consensuais entre credor e devedores. Apesar de assinalar direitos e declarar princípios, a lei não se preocupa em estruturar o procedimento deliberativo entre os credores. $\mathrm{Na}$ assembleia de credores, essa ausência de regulação é digna de nota. A comunhão de credores é coletividade em que cada integrante busca a satisfação de seu crédito. A solidariedade espontânea não é comumente encontrada. Ainda assim, comportamentos desleais entre os credores não podem ser admitidos. Cabe ao direito coibílos. Nesse contexto, o abuso do direito se mostra instrumento essencial para evitar condutas disfuncionais no âmbito da assembleia de credores. O presente estudo abordou, assim, aspectos teóricos e práticos necessários para a correta compreensão dos limites impostos aos credores no exercício do direito de voto.

Sob o ponto de vista teórico, a presente dissertação intentou demonstrar que subsistem deveres de lealdade entre os credores; que o dever de lealdade é um dos limites impostos ao exercício de direitos; e que o credor que desrespeita seu dever de lealdade para com os demais credores abusa do seu direito de voto. Há, portanto, fundamento dogmático para afirmar que pode ocorrer abuso do direito de voto pelo credor.

Com base nesse arcabouço, a dissertação buscou enfrentar problemas práticos: apresentou casuística das situações em que pode ocorrer abuso, questionou a forma de sua aferição e indicou sanções aplicáveis. 
Buscou-se, com isso, contribuir para que o procedimento deliberativo a respeito do plano de recuperação judicial possa servir aos propósitos para os quais foi estabelecido: permitir que soluções consensuais entre devedor e credores possam emergir de uma negociação estruturada, obtendo-se, com isso, a recuperação de empresas viáveis. 


\section{BIBLIOGRAFIA}

a.

\section{DOUTRINA}

ABETE, Luige, "Il ruolo del giudice ed il principio maggioritario nel novello concordato preventivo: brevi note", in Il fallimento e le altre procedure concorsuali, n. 03, 2008, pp. 253-258.

ABREU, Jorge Manuel Coutinho de, Do Abuso de Direito - Ensaio de um Critério em Direito Civil e nas Deliberações Sociais, Coimbra, Almedina, 1983.

ADAMEK, Marcelo Vieira von, Abuso de Minoria em Direito Societário (Abuso das Posições Subjetivas Minoritárias), Tese de Doutorado apresentada à Faculdade de Direito da Universidade de São Paulo, São Paulo, 2010.

AFRICK, Andrew, "Trading Claims in Chapter 11: How Much Influence Can Be Purchased in Good Faith Under Section 1126?", in The University of Pennsylvania Law Review, vol. 139, 1991, pp. 1393-1422.

ASCARELLI, Tullio, "Premissas ao Estudo do Direito Comparado", in Problemas das Sociedades Anônimas e Direito Comparado, $2^{a}$ ed., São Paulo, Saraiva, 1969, pp. 1-44.

ASCENSÃO, José de Oliveira, “A Desconstrução do Abuso de Direito”, in DELGADO, Mário L., ALVES, Jones F., Novo Código Civil - Questões Controvertidas, vol. 4, São Paulo, Método, 2005, pp. 33-54.

ASSIS, Araken de, Comentários ao Código de Processo Civil, vol. 4, Rio de Janeiro, Forense, 2009.

AZEVEDO, Antonio Junqueira de “(Parecer) Contrato de distribuição por prazo determinado com cláusula de exclusividade recíproca. Configuração de negócio jurídico per relationem na cláusula de opção de compra dos direitos do distribuidor pelo fabricante 
e conseqüente restrição da respectiva eficácia. Exercício abusvio do direito de compra, equivalente a resilição unilateral, sem a utilização do procedimento pactuado, com violação da boa-fé objetiva", in Novos Estudos e Pareceres de Direito Privado, São Paulo, Saraiva, 2009, pp. 287-310.

BAIRD, Douglas G., JACKSON, Thomas H., "Corporate Reorganizations and the Treatment of Diverse Ownership Interest: A Comment on Adequate Protection of Secured Creditors in Bankruptcy", in The University of Chicago Law Review, vol. 51, 1984, pp. $97-$ 130.

, "Loss Distribution, Forum Shopping, and Bankruptcy: A Reply to Warren”, in The University of Chicago Law Review, vol. 54, 1987, pp. 815-834.

, JACKSON, Thomas H., "Bargaining After the Fall and the Contours of the Absolute Priority Rule", in The University of Chicago Law Review, vol. 55, 1988, pp. 738789.

, “Bankruptcy's Uncontested Axioms", in Yale Law Journal, vol. 108, 1998, pp. 573-599.

RASMUSSEN, Robert K., "Control Rights, Priority Rights, and the Conceptual Foundations of Corporate Reorganizations", in Virginia Law Review, vol. 87, 2001, pp. 921-959.

BERNSTEIN, Donald S., “Absolute Priority, Valuation Uncertainty, and the Reorganization Bargain”, in Yale Law Journal, vol. 115, 2006, pp. 1930-1970.

RASMUSSEN, Robert K., “Antibankruptcy”, in Yale Law Journal, vol. 119, 2010, pp. 648-699.

BAKER, Cynthia A., MINKEL JR., Herbert P., "Claims and Control in Chapter 11 Cases: a Call for Neutrality", in Cardozo Law Review, vol. 13, 1991, pp. 35-101. 
BATISTA, Carolina S. J., CAMPANA FILHO, Paulo Fernando, MIYAZAKI, Renata Y., CEREZETTI, Sheila Christina Neder, "A Prevalência da Vontade da Assembleia Geral de Credores em Questão: o Cram Down e a Apreciação Judicial do Plano Aprovado por todas as Classes", in Revista de Direito Mercantil, Industrial, Econômico e Financeiro, vol. 143, 2006, pp. 202-242.

BEBCHUK, Lucian A., "A New Approach to Corporate Reorganizations", in Harvard Law Review, vol. 101, 1988, pp. 775-804.

FRIED, Jesse M. "The Uneasy Case for the Priority of Secured Claims in Bankruptcy”, in Yale Law Journal, vol. 105, 1996, pp. 857-934.

, "Ex Ante Costs of Violating Absolute Priority in Bankruptcy", in The Journal of Finance, vol. 57, 2002, pp. 445-460.

BENEDICT, Robert, "The Historical Position of the Rhodian Law", in Yale Law Journal, vol. 18, 1909, pp. 223-242.

BERNSEN, Jan Georg, BERNSEN, Rolf, "Stimmrechte und -verbote in der Gläubigerversammlung”, in DAHL, Michael, JAUCH, Hans-Gerd H., WOLF, Christian (org.), Sanierung und Insolvenz - Festschrift für Klaus Hubert Görg zum 70. Geburtstag, München, C. H. Beck, 2010, pp. 27-42.

BERNSEN, Rolf, BERNSEN, Jan Georg, "Stimmrechte und -verbote in der Gläubigerversammlung", in DAHL, Michael, JAUCH, Hans-Gerd H., WOLF, Christian (org.), Sanierung und Insolvenz - Festschrift für Klaus Hubert Görg zum 70. Geburtstag, München, C. H. Beck, 2010, pp. 27-42.

BERNSTEIN, Donald S., BAIRD, Douglas G., “Absolute Priority, Valuation Uncertainty, and the Reorganization Bargain”, in Yale Law Journal, vol. 115, 2006, pp. 1930-1970.

BESSONE, Darcy, Direitos Reais, 2a ed., São Paulo, Saraiva, 1996. 
BEVILAQUA, Clóvis, Código Civil dos Estados Unidos do Brasil, vol. 1, $3^{\mathrm{a}}$ ed., São Paulo/Rio de Janeiro, Francisco Alves, 1927.

BEZERRA FILHO, Manoel Justino, “A responsabilidade do garantidor na recuperação judicial do garantido", in Revista do Advogado, n. 105, 2009, pp. 129-134.

BITTER, Georg, "Sanierung in der Insolvenz - Der Beitrag von Treue- und Aufopferungspflichten zum Sanierungserfolg”, in Zeitschrift für das gesamte Unternehmens- und Gesellschaftsrecht, 2010, pp. 147-200.

BOUloS, Daniel M., Abuso do Direito no Novo Código Civil, São Paulo, Método, 2006.

BOZZA, Giuseppe, "La facoltatività della formazione delle classi nel concordato preventivo", in Il fallimento e le altre procedure concorsuali, n. 4, 2009, pp. 424-436.

BRADLEY, Michael, ROSENZWEIG, Michael, “The Untenable Case for Chapter 11”, in Yale Law Journal, vol. 101, 1992, pp. 1043-1095.

BRINKMANN, Moritz, "The Position of Secured Creditors in Insolvency", in EIDENMÜLLER, Horst, KIENINGER, Eva-Maria (orgs.), The Future of Secured Credit in Europe - European Company and Financial Law Review, Special Volume 2, 2008, pp. 248-272.

BROUDE, Richard F., "Cram Down and Chapter 11 of the Bankruptcy Code: the Settlement Imperative", in The Business Lawyer, vol. 39, 1984, pp. 441-454.

BUCKLEY, F.H., "The Bankruptcy Priority Puzzle", in Virginia Law Review, vol. 72, 1986, pp. 1393-1470.

BULOW, Jeremy I., SHOVEN, John B., "The Bankruptcy Decision”, in Bell Journal of Economics, vol. 9, 1978, pp. 437-456. 
CAHN, Andreas, DONALD, David C., Comparative Company Law, New York, Cambridge, 2010.

CAMPANA FILHO, Paulo Fernando, BATISTA, Carolina S. J., MIYAZAKI, Renata Y., CEREZETTI, Sheila Christina Neder, "A Prevalência da Vontade da Assembleia Geral de Credores em Questão: o Cram Down e a Apreciação Judicial do Plano Aprovado por todas as Classes", in Revista de Direito Mercantil, Industrial, Econômico e Financeiro, vol. 143, 2006, pp. 202-242.

CANARIS, Claus-Wilhelm, "Kreditkündigung und Kreditverweigerung gegenüber sanierungsbedürftigen Bankkunden", in Zeitschrift für das gesamte Handelsrecht und Wirtschaftsrecht, vol. 143, 1979, pp. 113-138.

CANDIAN, Aurelio, "Vendita di voto in concordato?", in Rivista del Diritto Commerciale e del Diritto Generale delle Obligazioni, 1919, Parte II, pp. 84-91.

CARLSON, David Gray, "Philosophy in Bankruptcy", in Michigan Law Review, vol. 85, 1987, pp. 1341-1389.

—, "Bankruptcy Theory and the Creditors' Bargain", in The University of Cincinnati Law Review, vol. 61, 1992, pp. 453-509.

, "On the Efficiency of Secured Lending", in Virginia Law Review, vol. 80, 1994, pp. 2179-2213.

CARVAlHOSA, Modesto, Comentários à Lei de Sociedades Anônimas, vol. 2, 2. ed., São Paulo, Saraiva, 1998.

CATTANEO, Giovanni, "Buona fede obbietiva e abuso del diritto", in Rivista trimestrale di diritto e procedura civile, 1971, pp. 613-659. 
CEREZETTI, Sheila Christina Neder, "O Papel dos Credores no Bankruptcy Code", in Revista de Direito Mercantil, Industrial, Econômico e Financeiro, vol. 151/152, 2009, pp. 164-186.

, “As Classes de Credores como Técnica de Organização de Interesses: em Defesa da Alteração da Disciplina das Classes na Recuperação Judicial”, in TOLEDO, Paulo Fernando C. S. de, SATIRO, Francisco (coord.), Direito das Empresas em Crise: Problemas e Soluções, São Paulo, Quartier Latin, 2012, pp. 367-385.

A Recuperação Judicial de Sociedade por Ações - O Princípio da Preservação da Empresa na Lei de Recuperação e Falência, São Paulo, Malheiros, 2012.

, BATISTA, Carolina S. J., CAMPANA FILHO, Paulo Fernando, MIYAZAKI, Renata Y., "A Prevalência da Vontade da Assembleia Geral de Credores em Questão: o Cram Down e a Apreciação Judicial do Plano Aprovado por todas as Classes", in Revista de Direito Mercantil, Industrial, Econômico e Financeiro, vol. 143, 2006, pp. 202-242.

MAFFIOLETTI, Emanuelle Urbano, "Transparência e Divulgação de Informações nos Casos de Recuperação Judicial de Empresas", in LUCCA, Newton de, DOMINGUES, Alessandra de A., ANTONIO, Nilva M. L. (coord.), Direito Recuperacional - Volume 2: Aspectos Teóricos e Práticos, São Paulo, Quartier Latin, 2012, pp. 79-105.

CHARLES, Scott K., "Trading Claims in Chapter 11 Cases: Legal Issues Confronting the Postpetition Investor", in Annual Survey of American Law, 1991, pp. 261-332.

COLOMBO, Giuliano, PAIVA, Luiz Fernando Valente de, "Recuperação Judicial e Cessão de Créditos: A Polêmica do Direito de Voto", in Revista do Advogado, n. 105, 2009, pp. 107-114.

COMPARATO, Fábio Konder, "Controle Conjunto, Abuso no Exercício de Direito de Voto e Alienação Indireta de Controle Empresarial", in Direito Empresarial: Estudos e Pareceres, São Paulo, Saraiva, 1995, pp. 81-102. 
, "Responsabilidade do Avalista na Concordata Preventiva do Avalizado", in Direito Empresarial: Estudos e Pareceres, São Paulo, Saraiva, 1995, pp. 476-490.

, SAlOMÃo FILHO, Calixto, O Poder de Controle na Sociedade Anônima, $4^{\mathrm{a}}$ ed., Rio de Janeiro, Forense, 2005.

CONTI, Joy F., KOZLOWSKI JR., Raymon F., FERLEGER, Leonard S., "Claims Trafficking in Chapter 11 - Has the Pendulum Swung Too Far?", in Bankruptcy Developments Journal, vol. 9, 1992, pp. 281-355.

CORDEIRO, António Menezes, Tratado de Direito Civil Português, Parte Geral, Tomo IV, Coimbra, Almedina, 2005.

, “A Lealdade no Direito das Sociedades", in Revista da Ordem dos Advogados, vol. 3, ano 66, 2006, pp. 1033-1066.

Da Boa Fé no Direito Civil, $4^{\mathrm{a}}$ reimp., Coimbra, Almedina, 2011.

COSTA, Mario Júlio de Almeida, Direito das Obrigações, 12ª ed., Coimbra, Almedina, 2009.

DASSO, Ariel A., Derecho Concursal Comparado, Tomos I e II, Buenos Aires, Legis, 2008.

DINAMARCO, Cândido Rangel, Instituições de Direito Processual Civil, vol. 4, $3^{\mathrm{a}}$ ed., São Paulo, Malheiros, 2009.

DONALD, David C., CAHN, Andreas, Comparative Company Law, New York, Cambridge, 2010.

EBERHART, Allan C., MOORE, William T., ROENFELDT, Rodney L., "Security Pricing and Deviations from the Absolute Priority Rule in Bankruptcy", in The Journal of Finance, vol. 45, 1990, pp. 1457-1469. 
EHRICKE, Ulrich, in KIRCHHOF, Hans-Peter, LWOWSKi, Hans-Jürgen, STÜRNER, Rolf (org.), Münchener Kommentar zur Insolvenzordnung, Bd. 1, München, C. H. Beck, 2001.

EIDENMÜLLER, Horst, "Die Banken im Gefangenendilemma: Kooperationspflichten und Akkordstörungsverbot im Sanierungsrecht”, in Zeitschrift für das gesamte Handelsrecht und Wirtschaftsrecht, vol. 160, 1996, pp. 343-373.

_ , "Prognoseentscheidung im Insolvenzplanverfahren: Verfahrenslähmung durch Minderheitenschutz?”, in Neue Juristische Wochenzeitschrift, n. 25, 1999, pp. 1937-1939.

, Unternehmenssanierung zwischen Markt und Gesetz, Köln, Otto Schmidt, 1999, pp. 583-806.

, "Obstruktionsverbot, Vorrangsregel und Absonderungsrechte", in RICHTER, Frank, SCHÜLER, Andreas, SCHWETZLER, Bernhard (org.), Kapitalgeberansprüche, Marktwertorientierung und Unternehmenswert - Festschrift für Prof. Dr. Dr. h.c. Jochen Drukarczyc zum 65. Geburtstag, München, Franz Vahlen, 2003, pp. 188-203.

_ _ "Regulierungswettbewerb im Unternehmensinsolvenzrecht: Ergebnisse einer empirischen Untersuchung", in Neue Zeitschrift für das Recht der Insolvenz und Sanierung, n. 14, 2010, pp. 545-551.

, "Die Eigenverwaltung im System des Restrukturierungsrechts", in Zeitschrift für das gesamte Handelsrecht und Wirtschaftsrecht, vol. 175, 2011, pp. 11-37.

FABIANI, Massimo, "Brevi riflessioni su omogeneità degli interessi ed obbligatorietà delle classi nei concordati", in Il fallimento e le altre procedure concorsuali, n. 4, 2009, pp. 437-445.

, Contratto e processo nel concordato fallimentare, Torino, UTET Giuridica, 2009. 
FASSBACH, Burkhard, Die cram down power des amerikanischen Konkursgerichtes im Reorganisationsverfahren nach Chapter 11 des Bankruptcy Code - Vorbild für das Obstruktionsverbot in der deutschen Insolvenzordnung, Frankfurt a.M., Peter Lang, 1997.

FERLEGER, Leonard S., KOZLOWSKI JR., Raymon F., CONTI, Joy F., "Claims Trafficking in Chapter 11 - Has the Pendulum Swung Too Far?”, in Bankruptcy Developments Journal, vol. 9, 1992, pp. 281-355.

FINCH, Vanessa, Corporate Insolvency Law, $2^{\mathrm{a}}$ ed., Cambridge, Cambridge University Press, 2009.

FLEISCHER, Holger, "Legal Transplants in European Company Law - The Case of Fiduciary Duties", in European Company and Financial Law Review, vol. 2, 2005, pp. 378-397.

FLESSNER, Axel "Philosophies of Business Bankruptcy Law: an International Overview", in ZIEGEL, Jacob S., Current Developments in International and Comparative Corporate Insolvency Law, Oxford, Clarendon, 1994, pp. 19-28.

FORTGANG, Chaim J., MAYER, Thomas M., "Valuation in Bankruptcy", in UCLA Law Review, vol. 32, 1985, pp. 1061-1132.

MAYER, Thomas M., "Trading Claims and Taking Control of Corporations in Chapter 11", in Cardozo Law Review, vol. 12, 1990, pp. 1-115.

FRANÇA, Erasmo Valladão Azevedo e Novaes, Conflito de Interesses nas Assembléias de S.A., Malheiros, São Paulo, 1993.

Invalidade das Deliberações de Assembléias das S.A., São Paulo, Malheiros, 1999. 
,, "A Assembléia-Geral de Credores na Nova Lei Falimentar", in Temas de Direito Societário, Falimentar e Teoria da Empresa, São Paulo, Malheiros, 2009, pp. 7-26. , “O Conceito de 'Benefício Particular' e o Parecer de Orientação 34 da CVM”, in Temas de Direito Societário, Falimentar e Teoria da Empresa, São Paulo, Malheiros, 2009, pp. 568-580.

, Ensaio sobre a Sociedade em Comum, Tese de Livre-Docência apresentada à Faculdade de Direito da Universidade de São Paulo, São Paulo, 2011.

FRANKS, Julian R., TOROUS, Walter N., “An Empirical Investigation of U.S. Firms in Reorganization", in J. Fin., vol. 44, 1989, pp. 747-769.

FRIED, Jesse M., BEBCHUK, Lucian A., "The Uneasy Case for the Priority of Secured Claims in Bankruptcy", in Yale Law Journal, vol. 105, 1996, pp. 857-934.

GALGANO, Francesco, La forza del numero e la legge della ragione: storia del principio di maggioranza, Bologna, Mulino, 2007.

GARDINO, Adriana Valério Pugliese, A Falência e a Preservação da Empresa: Compatibilidade?, Tese de Doutorado apresentada à Faculdade de Direito da Universidade de São Paulo, São Paulo, 2012.

GARDNER, Henry B., "SEC and valuation under Chapter X", in The University of Pennsylvania Law Review, vol. 91, 1943, pp. 440-465.

GOEBEL, Joachin, "Gläubigerobstruktion, Gläubigerstimmrecht und Beschlusskontrolle im Insolvenzverfahren über Unternehmen - Eine Untersuchung zu insolvenzrechtlichen Stimmverbote und zur Inhaltskontrolle nach $\$ 78$ InsO”, in Zeitschrift für Insolvenzrecht, Konkurs, Treuhand, Sanierung, n. 4, 2002, pp. 615-635. 
GOLDSCHMID, Paul M. "More Phoenix than Vulture: the Case for Distressed Investor Presence in the Bankruptcy Reorganization Process", in Columbia Business Law Review, 2005, pp. 191-274.

GONTIJO, Vinícius José Marques, "Falência e Recuperação de Empresas: Acordo de Credores na Assembleia Geral”, in Revista de Direito Mercantil, Industrial, Econômico e Financeiro, vol. 159/160, 2011, pp. 167-172.

GÖRG, Klaus G., "Gerichtliche Korrektur von Fehlentscheidungen der Gläubiger im Insolvenzverfahren", in Deutsche Zeitschrift für Wirtschafts- und Insolvenzrecht, n. 9, 2000, pp. 364-367.

GOTTWALD, Peter, "Die Interessengemeinschaft der Gläubiger eines insolventen Schuldners", in HABSCHEID, Walter J., HOFFMANN-NOWOTNY, Hans Joachim, LINDER, Willy, MEIER-HAYOZ, Arthur (coord.), Freiheit und Zwang - Festschrift zum 60. Geburtstag von Prof. Dr. iur. Dr. phil. Hans Giger, Bern, Stämpfli, 1989, pp. 195-211.

GRELL, Burkhard, "Stimmverbote im Insolvenzrecht", in Neue Zeitschrift für das Recht der Insolvenz und Sanierung, vol. 2, 2006, pp.77-81.

GROSS, Karen "Taking Community Interests into Account in Bankruptcy: an Essay", in Washington University Law Quarterly, vol. 72, 1994, pp. 1031-1048.

, Failure and Forgiveness: Rebalancing the Bankruptcy System, New Haven/London, Yale University Press, 1997.

HAFERKAMP, Hans-Peter, Die heutige Rechtsmißbrauchslehre - Ergebnis nationalsozialistischen Rechtsdenkens?, Berlin, Arno Spitz, 1995.

HAPPE, Eike, Die Rechtsnatur des Insolvenzplans, Köln/Berlin/München, Carl Heymanns, 2004. 
HARNER, Michelle M., "Activist Distressed Debtholders: the New Barbarians at the Gate", in Washington University Law Review, vol. 89, 2011, pp. 155-206.

HARRIS, Steven L., MOONEY JR., Charles W., “A Property-Based Theory of Security Interests: Taking Debtors' Choices Seriously", in Virginia Law Review, vol. 80, 1994, pp. 2021-2072.

HÄSEMEYER, Ludwig, “Obstruktion gegen Sanierung und gesellschaftrechtliche Treupflichten", in Zeitschrift für das gesamte Handelsrecht und Wirtschaftsrecht, vol. 160, 1996, pp. 109-132.

HECK, Philipp, Das Recht der großen Haverei, Berlin, H.W. Müller, 1889.

HENNRICHS, Joachim, "Treupflichten im Aktienrecht - zugleich Überlegungen zur Konkretisierung der Generalklausel des $\$ 242$ BGB sowie zur Eigenhaftung des Stimmrechtvertreters", in Archiv für die civilistische Praxis, vol. 195, 1995, pp. 221-273.

HERWEG, Christian, Das Obstruktionsverbot bei der Unternehmensanierung, Köln, RWS Kommunikationsforum, 2004.

HESS, Harald, Insolvenzrecht, Bd. 2, Freiburg i.Br., C. F. Müller, 2007.

HOHFELD, Wesley Newcomb, "Some Fundamental Legal Conceptions as Applied in Judicial Reasoning”, in Yale Law Journal, vol. 23, 1913, pp. 16-59.

HOPT, Klaus J., "Rechtspflichten der Kreditinstitute zur Kreditversorgung, Kreditbelassung und Sanierung von Unternehmen - Wirtschafts und bankrechtliche Überlegungen zum deutschen und französischen Recht”, in Zeitschrift für das gesamte Handelsrecht und Wirtschaftsrecht, vol. 143, 1979, pp. 139-173.

HUECK, Götz, Der Grundsatz der gleichmässigen Behandlung im Privatrecht, München/Berlin, C. H. Beck, 1958. 
HÜFFER, Uwe, Aktiengesetz, 5. ed., München, C.H. Beck, 2002.

JACKSON, Thomas H., KRONMAN, Anthony T., "Secured Financing and Priorities among Creditors", in Yale Law Journal, vol. 88, 1979, pp. 1143-1182.

, "Bankruptcy, Non- Bankruptcy Entitlements, and the Creditors's Bargain", in Yale Law Journal, vol. 91, 1982, pp. 857-907.

BAIRD, Douglas G., "Corporate Reorganizations and the Treatment of Diverse Ownership Interest: A Comment on Adequate Protection of Secured Creditors in Bankruptcy", in The University of Chicago Law Review, vol. 51, 1984, pp. 97-130.

, The Logic and Limits of Bankruptcy Law, Cambridge/London, Harvard University Press, 1986.

BAIRD, Douglas G., "Bargaining After the Fall and the Contours of the Absolute Priority Rule", in The University of Chicago Law Review, vol. 55, 1988, pp. 738789.

JAFFÉ, Michael, "Die Eigenverwaltung im System des Restrukturierungsrechts", in Zeitschrift für das gesamte Handelsrecht und Wirtschaftsrecht, vol. 175, 2011, pp. 38-54.

JHERING, Rudolph von, Der Geist des römischen Rechts auf den verschiedenen Stufen seiner Entwicklung, Bd. 1, Leipzig, Breitkopf und Härtel, 1852.

, "Die Reflexwirkungen oder die Rückwirkung rechtlicher Thatsachen auf dritte Personen", in Jahrbücher für die Dogmatik des heutigen römischen und deutschen Privatrechts, vol. 10, 1871, pp. 245-354.

JOSSERAND, Louis, De l'esprit des droits et de leur relativité - Théorie dite de l'Abus des Droits, 12ª ed. rev., Paris, Dalloz, 1939, pp. 311-312. 
JUNGMANN, Carsten, "Schlechterstellungsverbote im Insolvenzplanverfahren - Zum Verhältnis und Verständnis der $\S \S 245$ und 251 InsO”, in Zeitschrift für Insolvenzrecht, Konkurs, Treuhand, Sanierung, n. 2, 2006, pp. 135-150.

—, "Sachgerechte oder willkürliche Gruppenbildung im Insolvenzplan (Anmerkung zu LG Mühlhausen, Beschluss vom 17.09.2007 - 2 T 190/06)”, in Zeitschrift für Insolvenzrecht, Konkurs, Treuhand, Sanierung, n. 2, 2008, pp. 210-226.

KALANSKY, Daniel, Incorporação de Ações, São Paulo, Saraiva, 2012.

KLEE, Kenneth N., "All You Ever Wanted to Know About Cram Down Under the New Bankruptcy Code", in American Bankruptcy Law Journal, vol. 53, 1979, pp. 133-171.

, “Cram down II", in American Bankruptcy Law Journal, vol. 64, 1990, pp. 229244.

KOROBKIN, Donald R., "Rehabilitating Values: a Jurisprudence of Bankruptcy", in Columbia Law Review, vol. 91, n. 4, 1991, pp. 717-789.

, "Contractarianism and the Normative Foundations of Bankruptcy Law", in Texas. Law Review, vol. 71, 1993, pp. 541-631.

, "The Role of Normative Theory in Bankruptcy Debates", in Iowa Law Review, vol. 82,1996 , pp. 75-126.

KOZLOWSKI JR., Raymon F., CONTI, Joy F., FERLEGER, Leonard S., "Claims Trafficking in Chapter 11 - Has the Pendulum Swung Too Far?", in Bankruptcy Developments Journal, vol. 9, 1992, pp. 281-355.

KRONMAN, Anthony T., JACKSON, Thomas H., "Secured Financing and Priorities among Creditors", in Yale Law Journal, vol. 88, 1979, pp. 1143-1182. 
LARENZ, Karl, Methodenlehre der Rechtswissenschaft, 6. ed., Berlin/Heidelberg, Springer, 1991.

Allgemeiner Teil des Bürgerlichen Rechts, $9^{\mathrm{a}}$ ed. atual. por Manfred Wolf, München, C. H. Beck, 2004.

LEÃES, Luiz Gastão Paes de Barros, "Proibição de voto e conflito de interesses nas assembléias-gerais - Ação de anulação decorrente de voto de acionista com interesse conflitante", in Pareceres, vol. 1, São Paulo, Singular, 2004, pp. 175-184.

LEIPOLD, Dieter, “Zur Rechtsnatur des Insolvenzplans”, in Zeitschrift für Insolvenzrecht, Konkurs, Treuhand, Sanierung, n. 2, 2006, pp. 109-126.

LENT, Friedrich, "Vorbemerkung zu $\S \S$ 61-70", in Jaeger Kommentar zur Konkursordnung, Berlin, Walter de Gruyter, 1958.

LEVITIN, Adam J., "Finding Nemo: Rediscovering the Virtues of Negotiability in the Wake of Enron”, in Columbia Business Law Review, 2007, pp. 83-177.

, "Bankruptcy Markets: Making Sense of Claims Trading", in The Brooklyn Journal of Corporate, Financial \& Commercial Law, vol. 4, 2009, pp. 67-112.

LO CASCIO, Giovanni, "Concordati, classi di creditori ed incertezze interpretative", in Il fallimento e le altre procedure concorsuali, n. 10, 2009, pp. 1129-1136.

LOPUCKI, Lynn M., WHITFORD, William C., "Bargaining over Equity's Share in the Bankruptcy Reorganization of Large, Publicly Held Companies", in The University of Pennsylvania Law Review, vol. 139, 1990, pp. 125-196.

WHITFORD, William C., "Preemptive Cram Down", in American Bankruptcy Law Journal, vol. 65, 1991, pp. 625-647. 
, "The Unsecured Creditor's Bargain”, in Virginia Law Review, vol. 80, 1994, pp. 1887-1965.

LUBBEN, Stephen J., "Credit Derivatives and the Future of Chapter 11", in American Bankruptcy Law Journal, vol. 81, 2007, pp. 405-430.

LUCCA, Newton de, "Abuso do direito de voto do credor na assembleia geral de credores prevista nos arts. 35 a 46 da Lei 11.101/2005”, in Marcelo Vieira von Adamek (org.), Temas de Direito Societário e Empresarial Contemporâneos - Liber Amicorum Prof. Dr. Erasmo Valladão Azevedo e Novaes França, São Paulo, Malheiros, 2011, pp. 645-666.

LUTTER, Marcus, "Theorie der Mitgliedschaft - Prolegomena zu einem Allgemeinen Teil des Korporationsrechts", in Archiv für die civilistische Praxis, vol. 180, 1980, pp. 84-159.

, "Die Treupflicht des Aktionärs - Bemerkungen zur Linotype Entscheidung des BGH”, in Zeitschrift für das gesamte Handelsrecht und Wirtschaftsrecht, vol. 153, 1989, pp. 446-471.

, “Das Girmes-Urteil”, in Juristenzeitung, n. 21, 1995, pp. 1053-1056.

LYON-CAEN, Charles, RENAULT, Louis, Traité de Droit Commercial, tomo 7, 4a ed., Paris, Librairie Nouvelle de Droit et de Jurisprudence, 1914.

MACHADO, Nelson M., "A Assembleia Geral de Credores e seus Conflitos com a Assembléia Geral de Acionistas", in CASTRO, Rodrigo R. Monteiro de, ARAGÃO, Leandro Santos de (coord.), Direito Societário e a Nova Lei de Falências e Recuperação de Empresas, São Paulo, Quartier Latin, 2006, pp. 147-162.

MADAUS, Stephan, Der Insolvenzplan, Tübingen, Mohr Siebeck, 2011.

MAFFIOLETTI, Emanuelle U., CEREZETTI, Sheila C. N., "Transparência e Divulgação de Informações nos Casos de Recuperação Judicial de Empresas”, in LUCCA, Newton de, DOMINGUES, Alessandra de A., ANTONIO, Nilva M. L. (coord.), Direito 
Recuperacional - Volume 2: Aspectos Teóricos e Práticos, São Paulo, Quartier Latin, 2012, pp. 79-105.

MALOY, Richard, "A primer on cram down - how and why it works", in St. Thomas Law Review, vol. 16, 2003, pp. 1-57.

MARIANO, Álvaro Augusto Camargo, Abuso de Voto na Recuperação Judicial, Tese de Doutorado apresentada à Faculdade de Direito da Universidade de São Paulo, São Paulo, 2012.

MARTIN, Nathalie, "The role of history and culture in developing bankruptcy and insolvency systems: the perils of legal transplantation", in Boston College International \& Comparative Law Review, vol. 28, 2005, pp. 1-77.

MARTINS, Pedro Baptista, O Abuso do Direito e o Ato Ilícito, $2^{\text {a }}$ ed., 1941, São Paulo/Rio de Janeiro, Freitas Bastos, 1941.

MARTINS-COSTA, Judith, "Os Avatares do Abuso do Direito e o Rumo Indicado pela Boa-Fé”, in DELGADO, Mário L., ALVES, Jones F., Novo Código Civil - Questões Controvertidas, vol. 6, São Paulo, Método, 2007, pp. 505-544.

MAYER, Thomas M., FORTGANG, Chaim J., "Valuation in Bankruptcy", in UCLA Law Review, vol. 32, 1985, pp. 1061-1132.

FORTGANG, Chaim J., "Trading Claims and Taking Control of Corporations in Chapter 11", in Cardozo Law Review, vol. 12, 1990, pp. 1-115.

MCCALL, Brain M., “It's Just Secured Credit! The Natural Law Case in Defense of Some Forms of Secured Credit", in Indiana Law Review, vol. 43, 2009, pp. 7-44.

MELLO, Adriana M. T. de, THEODORO JR., Humberto, "Apontamentos sobre a Responsabilidade Civil na Denúncia dos Contratos de Distribuição, Franquia e Concessão 
Comercial", in Revista de Direito Mercantil, Industrial, Econômico e Financeiro, vol. 122, 2001, pp. 7-37.

MERZ, Hans, "Vom Schikaneverbot zum Rechtsmissbrauch", in Zeitschrift für Rechtsvergleichung, vol. 18, 1977, pp. 162-171.

MINKEL JR., Herbert P., BAKER, Cynthia A., "Claims and Control in Chapter 11 Cases: a Call for Neutrality", in Cardozo Law Review, vol. 13, 1991, pp. 35-101.

MIRANDA VALVERDE, Trajano de, Comentários à Lei de Falências, vol. 2, 4ª ed. atual. por J. A. Penalva Santos e Paulo Penalva Santos, Rio de Janeiro, Forense, 1999.

MIYAZAKI, Renata Y., BATISTA, Carolina S. J., CAMPANA FILHO, Paulo Fernando, CEREZETTI, Sheila Christina Neder, “A Prevalência da Vontade da Assembleia Geral de Credores em Questão: o Cram Down e a Apreciação Judicial do Plano Aprovado por todas as Classes", in Revista de Direito Mercantil, Industrial, Econômico e Financeiro, vol. 143, 2006, pp. 202-242.

MOONEY JR., Charles W., HARRIS, Steven L., “A Property-Based Theory of Security Interests: Taking Debtors' Choices Seriously”, in Virginia Law Review, vol. 80, 1994, pp. 2021-2072.

MOORE, William T., EBERHART, Allan C., ROENFELDT, Rodney L., "Security Pricing and Deviations from the Absolute Priority Rule in Bankruptcy", in The Journal of Finance, vol. 45, n. 5, 1990, pp. 1457-1469.

MOREIRA, Alberto Camiña, "Poderes da assembléia de credores, do juiz e atividade do Ministério Pùblico", in PAIVA, Luiz Fernando Valente de (coord.), Direito Falimentar e a Nova Lei de Falências e Recuperação de Empresas, São Paulo, Quartier Latin, 2005, pp. 247-274.

MOREIRA, José Carlos Barbosa, "Abuso do Direito", in Revista Trimestral de Direito Civil, vol. 13, 2003, pp. 97-110. 
MÜLLER-ERZBACH, Rudolf, "L'abuso di diritto secondo la dottrina giuridica teleologica", in Rivista del diritto commerciale e del diritto generale delle obligazzioni, 1950, Parte I, pp. 89-96.

Die Rechtswissenschaft im Umbau, München, Max Hueber, 1950.

MUNHOZ, Eduardo Secchi, "Anotações sobre os limites do poder jurisdicional na apreciação do plano de recuperação judicial", in Revista de Direito Bancário e do Mercado de Capitais, ano 10, n. 36, 2007, pp. 184-199.

NATOLI, Ugo, "Note preliminari ad una teoria dell'abuso del diritto nell'ordinamento giuridico italiano", in Rivista trimestrale di diritto e procedura civile, 1958, pp. 18-37.

NORNBERG, Scott F. "Classification of Claims Under Chapter 11 of the Bankruptcy Code: The Fallacy of Interest Based Classification", in American Bankruptcy Law Journal, vol. 69, 1995, pp. 119-166.

OELRICHS, Carsten Pay, Gläubigermitwirkung und Stimmverbote im neuen Insolvenzverfahren, Köln/Berlin/Bonn/München, Carl Heymann, 1999.

PACHULSKI, Isaac M., "The Cram Down and Valuation under Chapter 11 of the Bankruptcy Code", in North Carolina Law Review, vol. 58, 1980, pp. 925-965.

PAIVA, Luiz Fernando Valente de, COLOMBO, Giuliano, "Recuperação Judicial e Cessão de Créditos: A Polêmica do Direito de Voto", in Revista do Advogado, n. 105, 2009, pp. 107-114.

PAJARDI, Piero, Radici e ideologie del fallimento, $2^{\mathrm{a}}$ ed., Milano, Giuffrè, 2002.

PAPE, Gerhard, “Aufhebung von Beschlüssen der Gläubigerversammlung und Beurteilung des gemeinsamen Interesses nach §78 InsO”, in Zeitschrift für das gesamte Insolvenzrecht, n. 9, 2000, pp. 469-478. 
PASQUAY, Hans, “Die Rechtsstellung der Gläubigerversammlung im Konkurse und ihre Befugnisse (erstes Stück)", in Zeitschrift für das gesamte Handelsrecht und Konkursrecht (atual. Zeitschrift für das gesamte Unternehmens- und Gesellschaftsrecht), vol. 65, 1909, pp. 409-442.

PATTI, Salvatore, "Abuso del diritto (voce)", in Digesto delle discipline privatistiche (sezione civile), Torino, UTET, 1987.

PEEPLES, Ralph A., "Staying in: Chapter 11, Close Corporations and the Absolute Priority Rule”, in American Bankruptcy Law Journal, vol. 63, 1989, pp. 65-108.

PICKER, Randal C., "Voluntary Petitions and the Creditors' Bargain", in The University of Cincinnati Law Review, vol. 61, 1992, pp. 519-541.

PONTES DE MIRANDA, Francisco Cavalcanti, Tratado de Direito Privado, Tomo 5, Rio de Janeiro, Borsoi, 1955.

_, Tratado de Direito Privado, Tomo 27, Rio de Janeiro, Borsoi, 1960.

, Tratado de Direito Privado, Tomo 53, 2a ed., Rio de Janeiro, Borsoi, 1966.

, Tratado de Direito Privado, Tomo 50, $3^{\text {a }}$ ed., Rio de Janeiro, Borsoi, 1972.

RAISER, Thomas, VEIL, Rüdiger, Recht der Kapitalgesellschaften, $5^{\mathrm{a}}$ ed. atual., München, Franz Vahlen, 2010, § 16, Rn. 167, p. 243.

RANIERI, Filippo, “Norma scritta e prassi giudiziali nell'evoluzione della dottrina tedesca del Rechtsmißbrauch", in Rivista trimestrale di diritto e procedura civile, 1972, pp. 12161237.

, "Bonne Foi et Exercise du Droit dans la Tradition du Civil Law", in Revue Internationale de Droit Comparé, vol. 50, n. 4, 1998, pp. 1055-1092. 
, "Abuse of Law”, in BASEDOW, Jürgen, HOPT, Klaus J., ZIMMERMANN,

Reinhard, STIER, Andreas (coord.), The Max Planck Encyclopedia of European Private Law, vol. 1, Oxford, Oxford University Press, 2012, pp. 5-7.

RASMUSSEN, Robert K., SKEEL JR., David A., "The Economic Analysis of Corporate Bankruptcy Law", in American Bankruptcy Institute Law Review, vol. 3, 1995, pp. 85-115.

BAIRD, Douglas G., "Control Rights, Priority Rights, and the Conceptual Foundations of Corporate Reorganizations", in Virginia Law Review, vol. 87, 2001, pp. 921-959.

BAIRD, Douglas G., “Antibankruptcy”, in Yale Law Journal, vol. 119, 2010, pp. 648-699.

REGO, Marcelo L., "Direito de Voto", in LAMY FILHO, Alfredo, BULHÕES PEDREIRA, José Luiz (coord.), Direito das Companhias, vol. 1, Rio de Janeiro, Forense, 2009, pp. 399-401.

REINMANN, Mathias, "The Progress and Failure of Comparative Law in the Second Half of the Twentieth Century", in American Journal of Comparative Law., vol. 50, 2002, pp. 671-700.

REQUIÃO, Rubens, "A Crise do direito Falimentar Brasileiro - Reforma da Lei de Falências", in Revista de Direito Bancário e do Mercado de Capitais, vol. 20, 2003, pp. 199-207 (= Revista de Direito Mercantil, Industrial, Econômico e Financeiro, vol. 14, 1974, pp. 23-33).

Curso de Direito Falimentar, vol. 2, 14ª ed., São Paulo, Saraiva, 1995.

RESCIGNO, Pietro, "L’abuso del diritto", in Rivista di diritto civile, 1965, Parte I, pp. 203-290.

L'abuso del diritto, Bologna, Mulino, 1998. 
ROCCO, Alfredo, Il Concordato nel Fallimento e prima del Fallimento, Torino, Fratelli Bocca, 1902.

ROE, Mark J., "Bankruptcy and Debt: a New Model for Corporate Reorganization”, in Columbia Law Review, vol. 83, 1983, pp. 527-602.

, "Commentary on "On the Nature of Bankruptcy": Bankruptcy, Priority, and Economics”, Virginia Law Review, vol. 75, 1989, pp. 219-240.

ROENFELDT, Rodney L., EBERHART, Allan C., MOORE, William T., "Security Pricing and Deviations from the Absolute Priority Rule in Bankruptcy", in The Journal of Finance, vol. 45, n. 5, 1990, pp. 1457-1469.

ROSENZWEIG, Michael, BRADLEY, Michael, “The Untenable Case for Chapter 11”, in Yale Law Journal, vol. 101, 1992, pp. 1043-1095.

ROTONDI, Mario, L`Abuso di Diritto. Aemulatio", Padova, CEDAM, 1979 (=Rivista di Diritto Civile, 1923, pp. 105-128; pp. 208-352; pp. 416-457).

RÜMKER, Dietrich, "Verhaltenspflichten der Kreditinstitute in der Krise des Kreditnehmers", in Zeitschrift für Insolvenzrecht, Konkurs, Treuhand, Sanierung, n. 4, 1981, pp. 493-512.

RÜTHERS, Bernd, Die unbegrenzte Auslegung, 6 ${ }^{\mathrm{a}}$ ed., Tübingen, Mohr Siebeck, 2005.

RÜVE, Mirjam, Mehrheitsbeschaffung durch die Gruppenbildung im Insolvenzplan - Eine Untersuchung der Gestaltungsmöglichkeiten des Planerstellers und der Gläubiger sowie der Kontrollmöglichkeit des Gerichts, Hamburg, Dr. Kovač, 2008.

SACCHI, Roberto, Il principio di maggioranza nel concordato e nell'amministrazione controllata, Milano, Giuffrè, 1984. 
, "Concordato preventivo, conflitti di interessi fra creditori e sindicato dell'autorità giudiziaria", in Il fallimento, n. 1, 2009, pp. 30-36.

, "Dai soci di minoranza ai creditori di minoranza", in Il fallimento, n. 9, 2009, pp. 1063-1073.

SALOMÃO FILHO, Calixto, COMPARATO, Fábio Konder, O Poder de Controle na Sociedade Anônima, $4^{\mathrm{a}}$ ed., Rio de Janeiro, Forense, 2005. O Novo Direito Societário, $3^{\mathrm{a}}$ ed., São Paulo, Malheiros, 2006.

SATTA, Salvatore, "Voto, nel condordato preventivo di società, di creditore pignoratizio garantito dagli azionisti", in Il diritto fallimentare e delle società commerciali, vol. 46, parte I, 1971, pp. 201-204.

SCAGLIONE, Francesco, "L'abuso del diritto nel contratto", in Diritto e processo, vol. 8, 2012, pp. 237-262.

SCALZILLI, João Pedro, TELLECHEA, Rodrigo, SPINELLI, Luis Felipe, “Objetivos e Princípios da Lei de Falências e Recuperação de Empresas", in Revista Síntese, ano 5, n. 26, 2012, pp. 15-30.

SCHMIDT, Jan Peter, Zivilrechtskodifikation in Brasilien, Hamburg, Mohr Siebeck, 2009.

SCHMIDT, Karsten, Gesellschaftsrecht, $4^{\mathrm{a}}$ ed. atual., Köln/Berlin/Bonn/München, Carl Heymann, 2002.

, “Das Recht der Mitgliedschaft: Ist 'korporatives Denken’ passé?”, in Zeitschrift für das gesamte Unternehmens- und Gesellschaftsrecht, n. 2, 2011, pp. 108-135.

SCHULZ, Dirk, Treuepflichten unter Insolvenzgläubigern, Köln, RWS, 2003. 
SCHWARTZ, Alan, “A Contract Theory Approach to Business Bankruptcy”, in Yale Law Journal, vol. 107, 1998, pp. 1807-1851.

SCOTT, Robert, "The Truth about Secured Financing”, in Cornell Law Review, vol. 82, 1997, pp. 1436-1465.

SEUFFERT, Lothar, Zur Geschichte und Dogmatik des Deutschen Konkursrechts, Nördlingen, C. H. Beck, 1888.

SHOVEN, John B., BULOW, Jeremy I., “The Bankruptcy Decision”, in Bell J. Econ., vol. 9, n. 2, 1978, pp. 437-456.

SKEEL JR., David A., RASMUSSEN, Robert K., "The Economic Analysis of Corporate Bankruptcy Law”, in American Bankruptcy Institute Law Review, vol. 3, 1995, pp. 85-115. Debt's Dominion - A History of Bankruptcy Law in America, Princeton/Oxford, Princeton University Press, 2001.

SMID, Stefan, “Zum 'Obstruktionsverbot' - §245 InsO”, in Insolvenz \& Vollstreckung, n. 12, 1996, pp. 314-320.

, “Die 'cram down power' des deutschen Insolvenzgerichts", in Insolvenz \& Vollstreckung, n. 1, 2000, pp. 1-9.

, “[Rezenzion] Carsten Pay Oelrichs: Gläubigermitwirkung und Stimmverbote im neuen Insolvenzverfahren”, in Zeitschrift für Zivilprozeß, vol. 114, n. 1, 2001, pp. 105109.

SOUZA JUNIOR, Francisco Satiro de, PITOMBO, Antônio Sérgio Altieri de Moraes (coord.), Comentários à Lei de Recuperação de Empresas e Falência, $2^{\mathrm{a}}$ ed. rev., São Paulo, RT, 2007. 
SPINELLI, Luis Felipe, SCALZILLI, João Pedro, TELLECHEA, Rodrigo, “Objetivos e Princípios da Lei de Falências e Recuperação de Empresas", in Revista Síntese, ano 5, n. 26, 2012, pp. 15-30.

STANGHELLINI, Lorenzo, Le crisi di impresa fra diritto ed economia, Bologna, Mulino, 2007.

STELZIG, Peter, Zur Treuepflicht des Aktionärs unter besonderer Berücksichtigung ihrer geschichtlichen Entwicklung, Tese de Doutorado apresentada à Faculdade de Direito de Münster, Münster, 2000.

TABB, Charles Jordan, The Law of Bankruptcy, 2a ed., New York, Foundation Press, 2009.

TELLECHEA, Rodrigo, SCALZILLI, João Pedro, SPINELLI, Luis Felipe, “Objetivos e Princípios da Lei de Falências e Recuperação de Empresas", in Revista Síntese, ano 5, n. 26, 2012, pp. 15-30.

THALLER, Edmond-Eugène, Traité Elémentaire de Droit Commercial, $3^{\mathrm{a}}$ ed., Paris, Librairie Nouvelle de Droit et de Jurisprudence, 1904

THEODORO JR., Humberto, MELlO, Adriana M. T. de, "Apontamentos sobre a Responsabilidade Civil na Denúncia dos Contratos de Distribuição, Franquia e Concessão Comercial", in Revista de Direito Mercantil, Industrial, Econômico e Financeiro, vol. 122, 2001, pp. 7-37.

, Curso de Direito Processual Civil, vol. 2, 46 ed., Rio de Janeiro, Forense, 2011.

THOMAS, Richard D., "Tipping the Scales in Chapter 11: How Distressed Debt Investors Decrease Debtor Leverage and the Efficacy of Business Reorganization”, in Emory Bakruptcy Development Journal, vol. 27, 2010, pp. 213-253. 
TIMM, Wolfram, "Zur Sachkontrolle von Mehrheitsentscheidungen im Kapitalgesellschaftsrecht”, in Zeitschrift für das gesamte Unternehmens- und Gesellschaftsrecht, n. 3, 1987, pp. 403-442, pp. 404-405.

TOLEDO, Paulo Fernando C. S. de, ABRÃO, Carlos H. (coord.), Comentários à Lei de Recuperação de Empresas e Falência, São Paulo, Saraiva, 2005.

, "Recuperação Judicial - Sociedades Anônimas- Debêntures - Assembléia Geral de Credores - Liberdade de Associação - Boa-fé Objetiva - Abuso de Direito Cram Down - Par Condicio Creditorum", in Revista de Direito Mercantil, Industrial, Econômico e Financeiro, vol. 142, 2006, pp. 263-281.

, POPPA, Bruno, “UPI e Estabelecimento: uma Visão Crítica”, in in TOLEDO, Paulo Fernando C. S. de, SATIRO, Francisco (coord.), Direito das Empresas em Crise: Problemas e Soluções, São Paulo, Quartier Latin, 2012, pp. 267-294.

TOROUS, Walter N., FRANKS, Julian R., "An Empirical Investigation of U.S. Firms in Reorganization", in J. Fin., vol. 44, n. 3, 1989, pp. 747-769.

TUNG, Frederick, "Confirmation and Claims Trading", in Northwestern University Law Review, vol. 90, 1996, pp. 1684-1754.

UHLENBRUCK, Wilhelm (org.), Insolvenzordnung, 12 ${ }^{\mathrm{a}}$ ed., München, Franz Vahlen, 2003.

UNITED STATES GOVERNMENT, The Financial Crisis Inquiry Report, Washington, U.S. Government Printing Office, 2011.

VARELA, Antunes, "O Abuso do Direito no Sistema Jurídico Brasileiro", in Revista de Direito Comparado Luso-Brasileiro, vol. 1, n. 1, 1982, pp. 37-59.

VEIL, Rüdiger, RAISER, Thomas, Recht der Kapitalgesellschaften, $5^{\text {a }}$ ed. atual., München, Franz Vahlen, 2010, § 16, Rn. 167, p. 243. 
VORWERK, Sabine, Von der typenübergreifenden Gemeinschaft der insolvenzbeteiligten Gläubiger, Marburg, Tectum, 2007.

WARREN, Elizabeth, "Bankruptcy Policy", in The University of Chicago Law Review, vol. 54, n. 3, 1987, pp. 775-814.

, "Bankruptcy Policymaking in an Imperfect World", in Michigan Law Review, vol. 92, 1993, pp. 336-387.

, "Making Policy with Imperfect Information: the Article 9 Full Priority Debates", in Cornell Law Review, vol. 82, 1997, pp. 1373-1395.

WENDT, Otto, "Die exceptio doli generalis in heutigem Recht oder Treu und Glauben im Recht der Schuldverhältnisse”, in Archiv für die civilistische Praxis, 1906, pp. 1-417.

WHITFORD, William C., LOPUCKI, Lynn M., "Bargaining over Equity's Share in the Bankruptcy Reorganization of Large, Publicly Held Companies", in The University of Pennsylvania Law Review, vol. 139, 1990, pp. 125-196.

LOPUCKI, Lynn M., “Preemptive Cram Down”, in American Bankruptcy Law Journal, vol. 65, 1991, pp. 625-647.

WHITTAKER, Simon, ZIMMERMANN, Reinhard, "Good Faith in European Contract Law: Surveying the Legal Landscape", in WHITTAKER, Simon, ZIMMERMANN, Reinhard (org.), Good Faith in European Contract Law, Cambridge, Cambridge Press, 2000, pp. 7-62.

WIEDEMANN, Herbert, Gesellschaftsrecht I-Grundlagen, C. H. Beck, München, 1980.

WITTIG, Arne, “Obstruktionsverbot und Cram Down - §245 InsO im Lichte der LaSalle Street Entscheidung des U.S. Supreme Court v. 3.5.1999, in Zeitschrift für das gesamte Insolvenzrecht, n. 7, 1999, pp. 373-379. 
WÜRDINGER, Hans, Theorie der schlichten Interessengemeinschaft, Stuttgart, Ferdinand Enke, 1934.

WÜST, Günther, Die Interessengemeinschaft: ein Ordnungsprinzip des Privatrechts, Frankfurt a.M./Berlin, Alfred Metzner, 1958.

ZIMMERMANN, Reinhard, The Law of Obligations - Roman Foundations of the Civilian Tradition, Oxford, University Press, 1996.

, WHITTAKER, Simon, ZIMMERMANN, Reinhard, "Good Faith in European

Contract Law: Surveying the Legal Landscape", in WHITTAKER, Simon, ZIMMERMANN, Reinhard (org.), Good Faith in European Contract Law, Cambridge, Cambridge Press, 2000, pp. 7-62.

ZWEIGERT, Konrad, KÖTZ, Hein, Einführung in die Rechtsvergleichung, $3^{\mathrm{a}}$ ed., Tübingen, Mohr Siebeck, 1996.

b. JURISPRUDÊNCIA

b.(i). BRASIL

Superior Tribunal de Justiça-STJ

STJ, REsp n. 3710-0-RS, 4 ${ }^{\mathrm{a}}$ T., REl. Min. ANTÔNIO TORREÃO BRAZ, v.m., j. 21.06.1995, DJ 28.08.1995.

STJ, REsp 811.690/RR, $1^{\text {a }}$ T., Rel. Min. Denise ARrudA, v.u., j. 18.05.2006, DJ 19.06.2006.

STJ, REsp n. 883.859-SC, $3^{\text {a }}$ T., REL. Min. NANCY ANDRIGHI, v.u., j. 10.03.2009, DJe 23.03.2009.

STJ, AgRg no AI n. 812.533-SP, 4a T., Rel. Min. Fernando GonçAlves, v.u., j. 04.03.2010, DJe 22.03.2010. 
STJ, EDiv em AG n. 1.179.654-SP, 2a Seção, Rel. Min. Sidnei BenetTI, v.u., j. 08.03.2012, DJe 13.04.2012.

STJ, REsp n. 1.091.443-SP, Corte Esp., Rel. Min. MARIA THEREZA DE Assis MourA, v.u., j. 02.05.2012, DJe 29.05.2012.

\section{$\underline{\text { Tribunais Estaduais }}$}

TJRJ, AI n. 0037321-84.2011.8.19.0000, 5ª Câm. Cív., Rel. Des. Milton Fernandes De SouZA, v.u., j. 13.12.2011.

TJRO, AI n. 100.010.2006.006147-0, 1ª Câm. Civ., Rel. Des. Gabriel Marques De Carvalho, v. u., j. 04.09.2007.

TJRS, AI n. 70018219824, 6a Câm. Cív., Rel. Des. Artur Arnildo Ludwig, v.u., j. 19.04.2007, DJ 21.05.2007.

TJSP, AI n. 429.557-4/4-00, Câm. Esp. de Fal. e Rec. Jud., Rel. DeS. Pereira CalçAS, v.u., j. 15.03.2006, DJ 14.04.2006.

TJSP, AI n. 459.929.4/7-00, Câm. Esp. Fal. Rec. Jud., REL. Des. Boris KaUfFMANN, v.u., j. 06.12.2006, DJ 12.12.2006.

TJSP, AI n. 450.859-4/1-00, Câm. Esp. Fal. Rec. Jud. Dir. Priv., Rel. DeS. PereIRA CALÇAS, v.u., j. 17.01.2007, DJ 19.01.2007

TJSP, AI n. 460.339-4/7-00, Câm. Esp. Fal. Rec. Jud. de Dir. Priv., Rel. DeS. Lino MACHADO, v.u., j. 28.02.2007, DJ 09.03.2007.

TJSP, AI n. 493.240.4/1-00, Câm. Esp. Fal. Rec. Jud., REL. DES. Boris KAUfFMANN, v.u., j. 01.08.2007, DJ 08.08.2007.

TJSP, AI n. 531.656-4/5-00, Câm. Esp. Fal. e Rec. Jud., REl. Des. Costa Telles, v.u., j. 19.12.2007, DJe 10.01.2008.

TJSP, AI n. 500.624.4/8-00, Câm. Esp. de Fal. e Rec. Jud., Rel. Des. Lino Machado, v.u., j. 26.03.2008, DJ 01.04.2008.

TJSP, AI n. 520.208-4/6-00, Câm. Esp. Fal. Rec. Jud., Rel DeS. LinO MaChADO, v.u., j. 07.05.2008, DJ 20.05.2008. 
TJSP, AI n. 627.497-4/3-00, Câm. Esp. de Fal. e Rec. Jud., REL. DeS. RoMEU RICUPERO, v.u., j. 30.06.2009, DJ 08.07.2009.

TJSP, AI n. 368.631-4/1-00, Câm. Esp. de Fal. e Rec. Jud., Rel. DeS. Romeu RicuPERO, v.u., j. 18.08.2009, DJ 28.08.2009.

TJSP, AI n. 368.631-4/1-00, Câm. Esp. de Fal. e Rec. Jud., Rel. DeS. Romeu RicuPERO, v.u., j. 18.08.2009, DJ 28.08.2009.

TJSP, AI n. 612.654-4/6-00, Câm. Esp. de Fal. e Rec., Rel. Des. Pereira CALÇAS, v.u., j. 18.08.2009, DJ 28.08.2009.

TJSP, AI n. 649.192-4/2-00, Câm. Esp. de Fal. e Rec. Jud., Rel. DeS. Romeu Ricupero, v.u., j. 18.08.2009, DJ 28.08.2009.

TJSP, AI n. 994.09.282242-5, Câm. Res. Fal. e Rec., Rel. Des. Pereira CALÇAS, v.u., j. 06.04.2010, DJ 22.04.2010.

TJSP, AI n. 994.09.287683-7, Câm. Res. Fal. Rec., Rel. Des. Lino Machado, j. 01.06.2010, DJ 01.07.2010.

TJSP, AI n. 990.10.031858-6, Câm. Res. Fal. Rec., Rel. Des. LinO MaChado, v.m., j. 10.08.2010, DJ 23.08.2010

TJSP, AI n. 0322490-94.2010.8.26.0000, Câm. Res. à Fal. e Rec., Rel. DeS. PereIRA CALÇAS, v.u., j. 01.02.2011, DJ 09.02.2011.

TJSP, AI n. 0372448-49.2010.8.26.0000, Câm. Res. Fal. Rec., REl. DeS. PEREIRA CALÇAS, v.u., j. 01.02.2011, DJ 09.02.2011.

TJSP, AI n. 0136462-81.2011.8.26.0000, Câm. Res. Fal. Rec., REl. DeS. ElLIOT AKel, v.u., j. 18.10.2011, DJ 19.10.2011.

TJSP, AI n. 0136462-81.2011.8.26.0000, Câm. Res. Fal. Rec., Rel. Des. Elliot AKel, v.u., j. 18.10.2011, DJ 19.10.2010.

TJSP, AI n. 0136362-29.2011.8.26.0000, Câm. Res. Fal. Rec., REL. DeS. PEREIRA CALÇAS, v.u., j. 28.02.2012, DJ 28.02.2012.

TJSP, AI n. 0048861-03.2012.8.26.0000, 2a Câm. Res. Dir. Emp., Rel. Des. TASSO DUARTE DE MELO, v.u., j. 07.08.2012, DJ 09.08.2012.

TJSP, AI n. 0194436-42.2012.8.26.0000, $1^{\text {a }}$ Câm. Res. de Dir. Emp., REL. Des. TeIXEIRA LEITE, j. 02.10.2012, DJ 06.10.2012. 
TJSP, $2^{\text {a }}$ Câm. Res. Dir. Emp., Rel. Des. TAsso DuARTE De Melo, v.u., j. 16.10.2012, DJ 17.10.2012.

TJSP, AI n. 0211493-73.2012.8.26.0000, 1ª Câm. Res. Dir. Emp., Rel. Des. PereIRA CALÇAS, v.u., j. 30.10.2012, DJ 01.11.2012.

TJSP, AI n. 0103033-89.2012.8.26.0000, Câm. Res. Dir. Emp., Rel. DeS. RoberTo MAC CRACKEN, v.u., j. 06.11.2012, DJ 21.11.2012.

TJSP, AI n. 0198440-25.2012.8.26.0000, 1ª Câm. Res. Dir. Emp., Rel. Des. MAIA DA CunHA, v.u., j. 11.12.2012, DJ 11.12.2012.

TJSP, AI n. 0303530-56.2011.8.26.0000, Câm. Res. Fal. Rec., Rel. Des. RicArdo NEGRÃO, v.u., j. 27.11.2012, DJ 29.11.2012.

TJSP, AI n. 02.35130-87.2011.8.26.0000, 2 a Câm. Res. Dir. Emp., REL. Des. RiCARdo NEGRÃO, v.u., j. 04.12.2012, DJ 19.12.2012.

\section{Comissão de Valores Mobiliários - CVM}

CVM, Processo Administrativo RJ 2006/6785, j. 25.09.2006.

CVM, Processo Administrativo RJ 2009/13179, j. 09.09.2010

CVM, Processo Administrativo Sancionador RJ TA 2001/4977, j. 1912.2001.

CVM, Processo Administrativo Sancionador RJ TA 2002/1153, j. 06.11.2002.

\section{b.(ii). $\quad$ ESTADOS UNIDOS}

Northern Pacific Railway Co. v. Boyd, 228 U.S. 482 (1913).

Ashton et al. v. Cameron Water Improvement District No. One, 298 U.S. 513 (1936).

Case v. Los Angeles Lumber Products Co., Ltd., 308 U.S. 106 (1939).

Belleair v. Groves, 132 F.2d 542 (1942).

Young v. Higbee Co., 324 U.S. 204 (1945).

In re Landau Boat Co., 8 Bankr. 432 (1981). 
In re MacLEOD, 63 B.R. 654 (1986).

In re Federal Support Co., 859 F.2d 17 (1988).

In re Allegheny International, Inc., 118 B.R. 282 (1990).

In re Marin Town Center, 142 B.R. 374 (1992).

In re Landing, 157 B.R. 791 (1993).

Bank of America National Trust and Savings Association v. 203 North LaSalle Street Partnership, 526 U.S. 434 (1999).

Hewlett v. Hewlett-Packard Co., Del. Ch. LEXIS 44 (2002).

b.(iii). ITÁLIA

Corte di Cassazione, n. 20106, j. 18.09.2009.

b.(iv). AlemANHA

RG, II. Zivilsenat. j. 03.02.1914, in RGZ 84, 125.

BGH, II ZR 23/74, j. 05.06.1975.

BGH, II ZR 61/74, j. 16.02.1976.

BGH, II ZR 75/87, j. 01.02.1988.

BGH, IX ZR 178/91, j. 12.12.1991.

BGH, II ZR 205/94, j. 20.03.1995.

BGH, II ZR 240/08, j. 19.10.2009.

BGH, IX ZB 263/08, j. 10.12.2009.

BGH, IX ZB 153/04, j. 03.03.2005. 


\section{c. MATERIAIS LEGISLATIVOS}

COMISSÃO DE ASSUNTOS ECONÔMICOS DO SENADO FEDERAL, Parecer $n$. 534/2004 de relatoria do Sen. Ramez Tebet, em que foi apresentado substitutivo ao PL n. 71/2003, da Câmara dos Deputados.

HAHN, Otto, Die gesammten Materialien zur Konkursordnung, Berlin, Deckers, 1881.

DEUSTSCHER BUNDESTAG, "Gesetzentwurf der Bundesregierung: Entwurf einer Insolvenzordnung (InsO)”, in BT-Drucksache 12/2443, 1992. 


\section{RESUMO}

A dissertação tem como objeto o abuso do direito de voto na assembleia geral de credores. A Lei de Recuperação e Falência pauta-se pela adoção de soluções consensuais entre o devedor em crise e seus credores. Para tanto, cabe aos credores aceitar ou não o plano de recuperação judicial proposto pelo devedor. Entretanto, embora a lei seja pródiga em declarações de princípios, é sucinta quanto à estruturação do procedimento deliberativo. Confia-se na regra majoritária, e não são estabelecidas garantias estruturais à higidez do procedimento. A adoção da regra majoritária, contudo, nem sempre proporciona soluções equânimes. O direito societário dá exemplos de que o direito de voto pode ser exercido como instrumento para a obtenção de benefícios particulares ou para infligir danos à coletividade ou aos seus membros. Esse tipo de comportamento abusivo deve ser reprimido pelo direito. A dissertação busca determinar, dessa forma, em que situações o exercício do direito de voto pelos credores na deliberação acerca do plano de recuperação judicial poderá ser considerado abusivo. O trabalho está estruturado em cinco capítulos. No primeiro, investiga-se a natureza da coletividade de credores, concluindo-se que constitui uma comunhão de interesses. Em decorrência do início do procedimento concursal, surgem entre os credores deveres recíprocos de lealdade. No segundo capítulo, o instituto do abuso do direito é analisado em sua evolução histórica, demonstrando que também o abuso do direito de voto pelo credor é proibido pelo ordenamento jurídico. Questiona-se, então, a quais limites está adstrito o credor no exercício do voto. Em excurso necessário, ressalta-se a necessidade de que, além de ser avaliado o abuso do direito do voto pelo credor, seja avaliada a legalidade do plano. No terceiro capítulo, são abordadas as hipóteses de impedimento de voto, que delimitam quais credores são legitimados ao voto; ademais, discutem-se a possibilidade de aplicação analógica de regras societárias de impedimento de voto à assembleia de credores e hipóteses polêmicas de impedimento de voto pouco abordadas pela doutrina. No capítulo quatro, cerne do trabalho, apresenta-se casuística do abuso do direito de voto, e discutem-se quais os critérios para sua aferição. No capítulo quinto, são analisadas as possíveis sanções ao abuso do direito de voto.

Palavras-chave: Recuperação Judicial - Assembleia Geral de Credores - Impedimento de Voto - Abuso do Direito de Voto 


\begin{abstract}
This study aims to analyse the abuse of voting rights within the creditors' meeting. The Brazilian Insolvency Law Act fosters the adoption of consensual agreements between the debtor facing an economic crisis and his creditors. For achieving this end, creditors must deliberate about the judicial recuperation plan proposed by the debtor. The Act provides declarations of principles, but it has limited concern regarding the structure of the voting procedure. Furthermore, it contains the belief that the majority of the creditors will decide for the best result. There are practically no structural guarantees being provided for with regard to the procedure. However, the majority principle does not always yields adequate solutions. Corporate law offers many examples illustrating the misuse of voting rights, either to obtain personal benefits or to inflict damages on the collectivity. This kind of behavior is condemned by Law. This study establishes the situations in which the exercise of voting rights in the creditors' meeting may be regarded as abusive. The study is divided into five chapters. In the first one, the nature of the collectivity of creditors is investigated, concluding that a community of interests emerges as a result of the begin of the insolvency procedure. Based on this community of interests, fidutiary duties upon the creditors arise. In the second chapter, the institute of the abuse of right is historically analysed, with the conclusion that the abuse of voting rights by the creditors is prohibited. The parameters for the proper use of voting rights are analised. In a necessary excursus, it is showed that the legality of the plan must be also analysed by the court. In the third chapter, cases of voting prohibition are discussed, and so is the possibility of analogically applying corporate law rules on voting prohibition. In addition, some polemical cases are presented. In the fourth chapter, core of this study, both cases of abuse of voting rights and criteria for measuring this abuse are discussed. In the fifth chapter, possible sanctions to the abuse of voting rights are described.
\end{abstract}

Key Words: Judicial Reorganization - Creditor's Meeting - Voting Prohibition - Abuse of Voting Right 